\title{
Acute diarree in de huisartspraktijk : een onderzoek naar anamnese en microbiele oorzaken
}

Citation for published version (APA):

Rijntjes, A. G. (1987). Acute diarree in de huisartspraktijk : een onderzoek naar anamnese en microbiele oorzaken. [Doctoral Thesis, Maastricht University]. Rijksuniversiteit Limburg. https://doi.org/10.26481/dis.19871016ar

Document status and date:

Published: 01/01/1987

DOI:

10.26481/dis.19871016ar

Document Version:

Publisher's PDF, also known as Version of record

\section{Please check the document version of this publication:}

- A submitted manuscript is the version of the article upon submission and before peer-review. There can be important differences between the submitted version and the official published version of record.

People interested in the research are advised to contact the author for the final version of the publication, or visit the DOI to the publisher's website.

- The final author version and the galley proof are versions of the publication after peer review.

- The final published version features the final layout of the paper including the volume, issue and page numbers.

Link to publication

\footnotetext{
General rights rights.

- You may freely distribute the URL identifying the publication in the public portal. please follow below link for the End User Agreement:

www.umlib.nl/taverne-license

Take down policy

If you believe that this document breaches copyright please contact us at:

repository@maastrichtuniversity.nl

providing details and we will investigate your claim.
}

Copyright and moral rights for the publications made accessible in the public portal are retained by the authors and/or other copyright owners and it is a condition of accessing publications that users recognise and abide by the legal requirements associated with these

- Users may download and print one copy of any publication from the public portal for the purpose of private study or research.

- You may not further distribute the material or use it for any profit-making activity or commercial gain

If the publication is distributed under the terms of Article $25 \mathrm{fa}$ of the Dutch Copyright Act, indicated by the "Taverne" license above, 
'ACUTE DIARREE IN DE HUISARTSPRAKTIJK"

\author{
een onderzoek naar \\ anamnese en \\ microbiële oorzaken
}

\title{
PROEFSCHRIFT
}

ter verkrijging van de graad van doctor in de geneeskunde aan de Rijksuniversiteit Limburg te Maastricht, op gezag van de Rector Magnificus, Prof.dr.F.I.M. Bonke, volgens besluit van het College van Dekanen in het openbaar te verdedigen in de aula van de universiteit op vrijdag 16 oktober 1987 des namiddags om 16.00 uur precies

door

ANTONIUS GERARDUS RIJNTJES

geboren te Utrecht 

PROMOTORES :

Prof.dr.C.P.A. van Boven

Prof.dr.w.Brouwer

REFERENTEN :

Prof.dr.H.G.M. van der Velden, Nijmegen Prof.dr.F.Sturmans, Maastricht

Manuskript : M.Bruijstens

Druk : B.Meerstad

Het verschijnen van dit proefschrift werd financiëel mede mogelijk gemaakt door een bijdrage van Janssen Pharmaceutica Nederland. 
OPGEDRAGEN AAN

Jule de Leeuw-van Beek 
HOOFDSTUK 1 : ACUTE DIARREE

1.1 Het probleem "acute diarree"

1.2 Acute diarree: definitie en voorkomen

1.3 Typen van acute diarree

1.4 Voedselvergiftiging en voedselinfektie

1.5 Reizigersdiarree

1.6 Bakteriële oorzaken van diarree Salmonellose

1.6.2 Shigellose

$1 \cdot 6 \cdot 3$

Campylobacteriose

1.6.5 Overzichtstabel

1.7 .1 Overzichtstabel

HOOFDSTUK 2 : HANDELEN VAN DE HUISARTS: EEN LITERATUUROVERZICHT 
3.6.4 Voorkomen van diarree in het gezin

3.6.5 Verleende zorg

3.7 Laboratorium-bepalingen

HOOFDSTUK 4 : RESULTATEN

4.1

Presentatie van de klacht.

80

4.2

Beloop van de klacht

$4 \cdot 3$

Opname

111

$4 \cdot 4$

voorkomen van diarree in het gezin van de patient

$4 \cdot 5$ Handelen van de huisarts. De zorgverlening

HOOFDSTUK 5 : MICROBIELE OORZAKEN VAN DE KLACHT ACUTE DIARREE

5.1 Inleiding

$5 \cdot 2$

De opzet

140

5.3

Resultaten

5.4

Beloop van de klacht bij patien-

$5 \cdot 5$ ten van groep $B$

156 Nabes chouwing

HOOFDSTUK 6 : HET ANALYSEMODEL

6.1 Inleiding

165

6.2

Het analyse-model.

166

6.2.1 Likelihood ratio en odds ratio

168

6.2.2 Lineaire stapsgewijze regressie analyse

6.2 .3 Indikatieschema

HOOFDSTUK 7 : KONKLUSIES EN BESCHOUWING 183

Samenvatting / summary

Literatuur

Bijlagen

Dankwoord 


\section{INLEIDING}

In dit proefschrift is het onderwerp van onderzoek de klacht acute diarree zoals deze zich in de huisartspraktijik voordoet. De anamnestische gegevens vormden de bases voor de beschrijving van het klinisch beeld bij deze klacht. Mogelijke microbiële verwekkers werden aangetoond door middel van bakteriologisch en virologisch onderzoek. ook over het handelen van de huisarts bij deze klacht werden gegevens verzameld. Aan dit onderzoek ligt de veronderstelling ten grondslag, dat een beschrijving en een analyse op samenhang van deze gegevens voor de huisarts bruikbare informatie kan opleveren voor zijn diagnostiek en behandeling van de klacht acute diarree.

De klacht of symptoom acute diarree presenteert zich dikwijls samen met braken, buikpijn, koorts en algemene malaise, met andere woorden: het symptomencomplex acute gastro-enteritis.

Acute diarree en acute gastro-enteritis zijn derhalve niet hetzelfde. In het hier volgende overzicht van de frekwentie van voorkomen van acute diarree worden beide wel als zodanig behandeld, hierbij steunend op Hodgkin (1), die diarree als een obligaat symptoom van acute gastro-enteritis opvat.

Uitgaande van ongeveer 20.000 huisarts-patient-kontakten uit een a-selekte steekproef van 268 huisartsen in Nederland, stelde Van der wielen (2) in 1960 een rangorde op van alle klachten, die in een bepaalde periode 200 of meernalen aan de huisarts werden gepresenteerd.

De klacht "acute diarree" nam de 21 e plaats in van de 34 klachten, die aan dat kriterium voldeden.

Een huisarts met een praktijk van 2800 patienten wordt volgens van de Lisdonk, 1980, (3) per jaar gekonfronteerd met zo'n 140 gevallen van acute gastro-enteritis ( $5 \%$ van het patientenbestand). 
Uit gegevens van de Continue Morbiditeits Registratie (CMR) van het Nijmeegs Universitair Huisartsen Instituut, gebaseerd op 4 huisartspraktijken met een totale patientenpopulatie van ca. 12.000, is af te lezen, dat acute gastro-enteritis, gemeten over een periode van 10 jaar behoort tot de 20 meest frekwente aandoeningen, welke de huisarts worden gepresenteerd, en voor wat de mannen betreft de $8 \mathrm{e}$ en de vrouwen de loe plaats bezet (4).

In Rotterdam bestaat sinds 1966 een rapportagesysteem van een aantal ziektebeelden, waaronder acute gastro-enteritis van onbekende oorzaak, waaraan door ongeveer $10 \%$ van de plaatselijke huisartsen wordt deelgenomen. Aannemend dat de gegevens van dit peilstation representatief zouden zijn voor de hele stad, worden berekend dat in Rotterdam 4.000 gevallen van gastro-enteritis per 100.000 inwoners per jaar voorkomen, waarvoor de huisarts geraadpleegd wordt (5).

zouden deze gegevens, die overigens goed overeenkomen met die van de Lisdonk, geldigheid hebben voor heel Nederland, dan zouden per jaar 560.000 Nederlanders hun huisarts raadplegen voor de klacht acute diarree. Uit deze cijfers blijkt, dat acute gastro-enteritis een niet te verwaarlozen morbiditeit in Nederland veroorzaakt.

Gesteld kan echter worden, dat de gegevens over acute diarree ten aanzien van de oorzaken, het klinisch beeld en het beloop voornamelijk verkregen zijn in studies van klinische patienten, van bepaalde bevolkings- of leeftijdsgroepen, of gericht op één oorzakelijke bakteriële of virale verwekker. De mogelijkheid doet zich voor, dat mede gezien het vroege stadium waarin klachten door de huisarts worden gezien $(6,7,8)$ de op deze wijze verkregen informatie en de weergave daarvan in klinische leerboeken niet zonder meer toepasbaar is in de huisartspraktijk $(9,10)$. Daarbij komt ook dat de frekwentie van voorkomen van verschillende microbiële verwekkers wellicht niet juist wordt weergegeven voor de patien- 
tenpopulatie, die zich met de klacht acute diarree tot de huisarts wendt (11).

De hierboven beschreven veronderstellingen en konstateringen hebben geleid tot dit onderzoek naar de klacht acute diarree. Het onderzoek werd verricht in een aantal huisartspraktijken in de regio Heuvelland van zuid Limburg. Gedurende de periode van uitvoering werden op eenvolgend de patienten met deze klacht in het onderzoek betrokken.

De uitwerking van de veronderstellingen is tot stand gekomen met behulp van de volgende vraagstellingen.

1. Hoe doet de klacht acute diarree zich voor in de huisartspraktijk, in termen van presentatie, beloop, aard van de arts-patient-kontakten en het voorkomen van diarree in het gezin van de patient?

2. Wat is de verleende zorg, in termen van onderzoek, diagnose en behandelingsplan, aan patienten met acute diarree, door de huisarts in een aantal huisartspraktijken in de regio Heuvelland van zuid-Limburg?

3. Welke zijn de microbiële verwekkers van de klacht acute diarree in deze huisartspraktijken?

4. Wat is de samenhang tussen een aantal anamnestische gegevens bij de klacht acute diarree en de kweekuitslag?

Indeling van de studie.

Voorafgaand aan de beschrijving van de methode van onderzoek en de bespreking van de resultaten ( $z$ ie hoofdstuk 3 en volgende) wordt in deze studie eerst een literatuuroverzicht gegeven van de klacht acute diarree.

zoals reeds is opgemerkt, is de bestaande 
literatuur over acute gastro-enteritis weliswaar zeer uitgebreid, maar niet toegespitst op de huisartspraktijk.

Niettemin is getracht in dit overzicht gebruik te maken van zoveel mogelijk voor de huisarts relevante literatuur-gegevens.

In hoofdstuk 1 wordt aandacht geschonken aan de indeling en oorzaken van acute diarree. De bespreking van de bakteriële agentia is beperkt tot die micro-organismen, die de huisarts door middel van een Streeklaboratorium kan laten detekteren.

Er zijn zeker veel meer bakteriële micro-organismen in het kader van acute diarree te bespreken, maar aangezien de huisarts in Nederland deze agentia niet via een kweekaanvrage op het spoor kan komen, zullen zij in mindere mate invloed op zijn handelen kunnen uitoefenen.

Met de bespreking van de virologie is het anders gesteld: er is een keuze gemaakt uit de virussen die in de literatuur algemeen als verwekkers van acute diarree kunnen worden beschouwd. Immers detektie naar virologische verwekkers bij acute diarree wordt zelden of nooit aangevraagd door de huisarts.

In hoofdstuk 2 volgt een beschrijving van het handelen van de huisarts bij de klacht acute diarree.

Deze is voornamelijk beperkt tot de literatuurgegevens van Westeuropese auteurs, met opzet zo gekozen, omdat zowel het voorkomen van microbièle verwekkers als de hygiënische omstandigheden bij de klacht acute diarree geografisch nogal kunnen verschillen en de resultaten van onderzoekingen elders in de wereld moeliljk zijn te vergelijken met die van de Nederlandse huisarts.

In het tweede deel van deze studie worden de resultaten besproken van het onderzoek naar de klacht acute diarree in 25 huisartspraktijken in de regio Heuvelland van Zuid-Limburg.

In hoofdstuk 3 wordt een beschrijving gegeven 
van de methode van onderzoek.

Hoofdstuk 4 bevat gegevens over hoe de klacht acute diarree $\mathrm{zich}$ aan de huisarts voordoet, alsmede over het beloop van de aandoening en het voorkomen van diarree in het gezin van de patient. Het hoofdstuk wordt afgesloten met een beschrijving van de zorgverlening van de huisarts bij deze klacht (zie vraagstelling 1 en 2).

De resultaten van het voorkomen van microbiële verwekkers bij de klacht acute diarree in dit onderzoek, worden in hoofdstuk 5 toegelicht (zie vraagstelling 3 ).

In hoofdstuk 6 wordt de betekenis van een aantal anamnestische gegevens van de klacht acute diarree voor de huisarts in relatie tot het voorkomen van microbiële agentia aan de orde gesteld (zie vraagstelling 4). Er wordt een voorstel voor een indikatieschema gedaan. De studie wordt afgesloten met een beschouwing (hoofdstuk 7) over de zin van het gebruik van een anamnese door de huisarts bij de klacht acute diarree, die voornamelijk gebaseerd is op klinisch epidemiologische gegevens. Ook de samenhang van de anamnese met het voorkomen van microbiële verwekkers bij deze klacht in de huisartspraktijk wordt besproken. Er worden enkele aanbevelingen gedaan met betrekking tot de zorgverlening in de huisartspraktijk bij patienten met de klacht acute diarree en ten aanzien van het verkrijgen van onderzoeksgegevens in het werkterrein van de huisarts. 
HOOFDSTUK 1 : ACUTE DIARREE

In dit hoofdstuk worden enkele, in het kader van het onderzoek relevante, aspekten van acute diarree besproken aan de hand van de literatuur.

\subsection{Het probleem "acute diarree".}

Acute diarree als gevolg van infektieuze (gastro)enteritis is een wereldwijd probleem $(1,2,3)$. In ontwikkelingslanden met onvoldoende hygiënische en sanitaire voorzieningen is diarree een volksgezondheidsprobleem van de eerste orde. Vooral bij kinderen jonger dan 5 jaar is in deze landen diarree de oorzaak van een hoge morbiditeit, een aanzienlijke mortaliteit, en onderhoudt of verergert het de ondervoeding. In de geindustrialiseerde Westerse landen komen, zoals in de inleiding werd aangegeven, episoden van acute diarree eveneens veelvuldig voor. Het aantal episoden per jaar is slechts te schatten; slechts een deel van de patienten met acute diarree roept de hulp van de arts in en hiervan wordt een onbekend aantal geregistreerd. In de Westerse wereld is acute diarree in de grote meerderheid van de gevallen een kortdurende onschuldige aandoening, die bij uitzondering oorzaak is van sterfte. Het probleem van acute diarree is dan ook van geheel andere aard dan in de ontwikkelingslanden. Door het ermee gepaard gaande werkverzuim is het een ekonomisch probleem; doordat een toch niet onaanzienlijk aantal patienten met acute diarree zich tot de huisarts wenden is het een medisch probleem in termen van juiste diagnostiek en behandeling en door het beslag in tijd en geld dat door patienten met deze klacht op de gezondheidszorgvoorzieningen wordt gelegd; het is een epidemiologisch probleem in de zin van dat explosies van acute besmettelijke diarree dienen te worden voorkomen door gerichte 
bronopsporing, hygiënische maatregelen en regelmatige of continue surveillance. Het moderne reizigersverkeer heeft tot gevolg, dat acute diarree in de vorm van de zogenaamde "reizigersdiarree" in toenemende mate een toeristisch probleem wordt. De mogelijkheid van import en uitbreiding van meer uitheemse ziektekiemen neemt hierdoor toe en de reiziger stelt steeds dwingender de vraag naar profylaxe.

\subsection{Acute diarree: definitie en voorkomen.}

Van acute diarree is sprake wanneer het voor een persoon gebruikelijke defaecatiepatroon plotseling verstoord wordt door het optreden van te veel, te frequente en te dunne ontlasting $(4,5)$. De toename in volume en frekwentie en de verandering van konsistentie tot waterdun of dunne ongebonden faeces, vinden hun oorzaak in een toename in de faecale water excretie ( $\sigma$ ). Een episode van acute diarree duurt meestal 3 tot 7 dagen, maar kan 10 tot 14 dagen duren. Bij diarree met een duur van meer dan 14 dagen is sprake van chronische diarree.

In tabel $1.1 \mathrm{zijn}$, ontleend aan een aantal in de literatuur gepubliceerde overzichten $(7,8,9)$, de verschillende oorzaken van diarree samengevat. Aan het hiervoor beschreven beeld van acute diarree ligt meestal een infektie of voedselvergiftiging door bakteriële toxinen ten grondslag $(4,5,10,11)$. In deze gevallen gaat het volgens Hodgkin (12) obligate symptoom van diarree veelal gepaard met één of meer van de verschijnselen van braken, buikpijn, koorts, hoofdpijn, anorexie en malaise. Acute diarree tezamen met deze verschijnselen vormt het beeld van acute gastro-enteritis. Acute gastro-enteritis is, evenals acute diarree, veelal een duidelijke en bruikbare diagnose. De diagnose is in zoverre weinig specifiek aangezien zeer verschillende micro-organismen éénzel fde 
beeld kunnen veroorzaken.

TABEL 1.1 .

Oorzaken van (acute) diarree.

1. Infekties - bakteriën

- virussen

- parasieten

- schimmels

2. Ontstekingen

- colitis ulcerosa

- ziekte van Crohn

- toxische e.a. beschadiging

- diverticulitis

3. Opname-stoornissen

- cystic fibrosis

- coeliakie, spruw

- koolhydraat malabsorptie

4. Voeding

- dieetfouten, alkohol

- voedselvergiftiging door bakteriële en andere to$x$ inen

- chemische stoffen

5. Immuunstoornissen en allergie

- koemelk overgevoeligheid

- immuundeficiëntie

6. Endocrinologische afwijkingen

- pancreastumoren

- V.I.P. producerende tumoren

7. Psychologisch - psychogene diarree

8. Geneesmiddelen - antibiotica, laxantia, digitalis

De kennis van de verwekkers van acute diarree en van de pathofysiologie van infektieuze diarree is de laatste 10 tot 15 jaar sterk toegenomen. Tenminste 13 verschillende bakterie-soorten zijn beschreven als verwekkers 
van acute diarree $(3,13,14)$. Tezamen met een toenemend aantal nieuwe virussen (15) als oorzaak en de parasitaire verwekkers zijn er een 30-tal micro-organismen bekend die bij de mens acute gastro-enteritis kunnen veroorzaken. Tabel 1.2A en $1.2 \mathrm{~B}$ geven een overzicht van de meest voorkomende microbiële verwekkers van acute diarree bij de mens.

TABEL $1.2 \mathrm{~A}$

Bakteriële oorzaken van acute diarree.

Voedselinfektie:

Salmonellae

S.enteritidis en vele andere serotypen

Shigellae

Campylobacter

jejuni

in Nederland vnl. Sh.sonnei.

Yersinia enterocolitica

Escherichia coli - enterotoxische stammen, ETEC

- enteropathogene stammen EPEC

- enteroinvasieve stammen EIEC

- enterohaemorrhagische stammen EHEC

- enteroadherente stammen EAEC

Vibrio cholerae $0: 1$ en V.cholerae non $0: 1$ vibrio parahaemolyticus e.a. Vibrio spp. Clostridium difficile - i.a.a. antibiotica

Voedselvergiftiging:

Staphylococcus aureus

Clostridium perfringens

Bacillus cereus 
TABEL $1.2 \mathrm{~B}$

Virale en parasitaire oorzaken van acute diarree

\section{Viraal}

Rotavirus, groep $A$ en $B$ Adenovirus, type 40,41 Norwalkvirus en Norwalkachtige virussen Astrovirus

Calicivirus Coronavirus Parvovirus Andere "kleine ronde virussen"
Parasitair

Protozoèn:

Entamoeba Histolytica Giardia lamblia Cryptosporidium Isospora belli Balantidium coli Wormen:

Schistosoma mansoni Schistosoma intercalatum

Trichuris trichiura Strongyloides stercoralis

Ondanks deze toename in kennis is het lang niet altijd mogelijk bij een patient met acute diarree een oorzaak vast te stellen. Was het 10 jaar geleden gebruikelijk dat slechts bij 208 van de patienten een verwekker kon worden geisoleerd, nu zou onder ideale omstandigheden een isolatie-percentage van 70-80\% mogelijk zijn $(3,18)$. Dupont $(16,17)$ vermeldt, dat in de Verenigde staten van Amerika bij kinderen met diarree in 40-60\% van de gevallen geen etiologische diagnose gesteld kon worden. Het lijkt waarschijnlijk dat buiten epidemische explosies éénzelfde isolatie-percentage in Nederland gevonden wordt. Dat het percentage isolaties sterk beïnvloed wordt door de lokale epidemische situatie wordt geillustreerd met tabel 1.3. , ontleend aan de publikatie van Freyvogel (9). 
TABEL 1.3 .

Voorkomen in percentages van groepen microbiële verwekkers in Bangladesh, Mexico en Engeland.

\section{Bangladesh Mexico Engeland}

$\begin{array}{lccc}\text { Bacteriën } & 53 & 65 & 49,3 \\ \text { Virussen } & 24 & 10 & 6,8 \\ \text { Parasieten } & 6 & 3 & 4,1 \\ \text { Schimmels } & - & - & 1,4 \\ \text { Onbekend } & 17 & 22 & 38,4\end{array}$

Bron: Freyvogel 1982 (9)

1.3. Typen van acute diarree

Het door klinisch en experimenteel onderzoek toegenomen inzicht in de ontstaanswijze van acute diarree makt het mogelijk hierin verschillende typen of vormen te onderscheiden. Twee benaderingen worden hierbij gevolgd: een pathofysiologische en een pathogenetische. De volgende indeling, ontleend aan Farmer (19) en Goldfinger (4) gaat uit van de eerste benadering.

Secretoire diarree: activatie van het adenyl-cyclase in de enterocyten leidt tot een verhoogde secretie van het natrium-ion en een verminderde terugresorbtie van het chloorion, resulterend in een verhoogde secretie van electrolyten met het daaraan gebonden water. Het is in de dunne darm, duodenum en jejunum, waar dit proces vooral plaats vindt en het is langs deze weg dat enterotoxinen, met het choleratoxine als klassiek voorbeeld, diarree veroorzaken.

Exudatieve diarree: een ontstekingsreactie ten gevolge van cel- en weefselbeschadiging door cytotoxische toxinen en/of het binnen- 
dringen van bakteriën in het darmslijmvlies ligt aan dit type diarree ten grondslag. Het ontstekingsproces is meestal gelokaliseerd in het laatste deel van het ileum en in het colon. De diarree bij bacillaire dysenterie ontstaat op deze wijze.

osmotische diarree: een verminderde resorbtie van klein moleculaire stoffen leidt tot het vasthouden van water in het darmlumen. De oorzaak kan zijn gelegen in een beschadiging van de enterocyten in de dunne darm en vlokatrofie door een virusinfektie. De verminderde opname van suikers door een disaccharidase deficiëntie is hiervan een voorbeeld. Diarree door versterkte mobiliteit: de verkorting in de kontakttijd tussen darminhoud en darmwand bij een versnelde passage ten gevolge van een verhoogde darmmotoriek leidt tot een verminderde resorbtie van opgeloste stoffen en water. Deze vorm van diarree zal meestal als een komponent bij de eerder genoemde typen van diarree voorkomen. Zowel een ontstekingsreaktie (exudatieve diarree) als een volume-toename (secretoire en osmotische diarree) veroorzaken door prikkeling een verhoogde darmperistaltiek.

De door Verhoeve (20) gehanteerde indeling van acute diarreën is een voorbeeld van de benadering uitgaande van de pathogenese. Enterotoxische diarree: diarree veroorzaakt door enterotoxinevormende bakteriën. De enterotoxinen veroorzaken een secretoire diarree; het klassieke voorbeeld hiervan is de cholera. Bij deze vorm van diarree is uitsluitend sprake van een door het toxine veroorzaakte funktionele stoornis zonder celof weefselbeschadiging.

Invasieve diarree: dit type diarree berust op celbeschadiging door cytotoxische toxinen, het penetreren van de enterocyt door bakteriën (bv. Shigella) of het doordringen tot in de lamina propria (Salmonellae). De ontstekingsreaktie als antwoord op de celbeschadiging en de bakteriële invasie geeft het beeld van de exudatieve diarree, zo kenmerkend voor 
de bacillaire dysenterie.

Virale diarree: het basismechanisme van de virale pathogeniteit is de dood van de geinfekteerde cel (enterocyt). Ontsteking en vlokatrofie zijn het gevolg. Diarree ten gevolge van een virusinfektie is meestal de resultante van verminderde resorptie (celdood en vlokatropie), ontsteking en secretie veroorzaakt door bij de ontstekingsreaktie gevormde prostaglandinen.

Uit het bovenstaande blijkt de samenhang van de indelingen. Zo zal een enterotoxische diarree het karakter hebben van een secretoire diarree; een invasief micro-organisme zal aanleiding geven tot een exudatieve diarree. De praktische betekenis van de klassifikatie is gelegen in de samenhang tussen het aspekt van de ontlasting en het type diarree: een enterotoxische, secretoire diarree is helder, waterig, isosmotisch, volumineus en bevat microscopisch geen leucocyten; een invasieve, exudatieve diarree is minder waterig en volumineus, kan bloed en slijm bevatten en in het microscopisch preparaat zijn meestal veel leucocyten aanwezig. Het onderscheid blijkt in de praktijk echter niet altijd duidelijk. Bij één verwekker kunnen meerdere mechanismen - enterotoxine en penetratie - zich voordoen en in de huisartspraktijk zal zeker gelden dat bij de meerderheid van de onschuldige vormen van acute diarree het onderscheid niet te maken is.

\subsection{Voedselvergiftiging en voedselinfektie.}

Voedsel en in mindere mate besmet water zijn de belangrijkste besmettingswegen waarlangs de verwekkers van acute gastro-enteritis de mens bereiken. Treedt na een maltijd een acute gastro-enteritis op dan is het gebruikelijk te spreken van een voedselvergiftiging. Juister is, om met Huisman (21) en Beckers $(22,23)$ een onderscheid te maken tussen ingestie van in voedsel aanwezige 
bakteriële toxinen, een voedselvergiftiging en het besmet en geinfekteerd worden door in het voedsel aanwezige micro-organismen, een voedselinfektie. Een voedselvergiftiging heeft doorgaans een korte incubatietijd van enkele uren. De verschijnselen bij een voedselinfektie treden meestal na 24 uur of later op, omdat de bakteriën zich na opname eerst dienen te vermenigvuldigen. De incubatieperiode kan derhalve een belangrijke aanwijzing geven over de mogelijke oorzaak. Omdat zowel dosis als virulentie de incubatietijd beïnvloeden, is in de praktijk deze scheiding lang niet altijd even duidelijk.

Tabel 1.4. geeft de in Nederland aangegeven gevallen van voedselvergiftiging en voedselinfektie weer over de jaren 1976-1985.

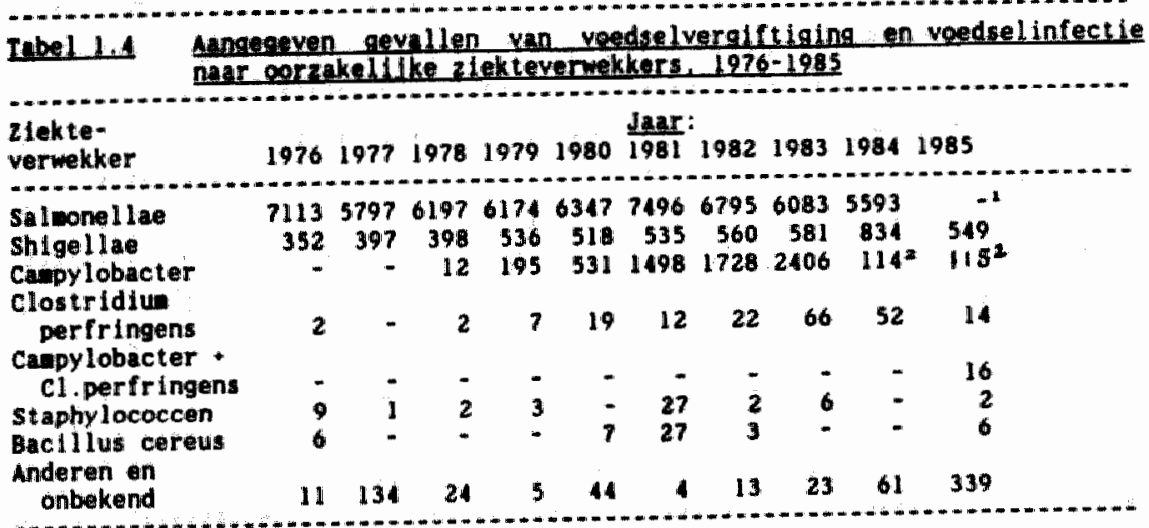

gron: Geneeskundige Inspectie van de Volksgezondheld.

1 Verpllichte aanglfte in 1985 vervallen.

- Caspylobacter werd tot 1984 aangegeven als woedselvergiftiging: na 1983 is uitslultend bij 2 of meer infectles aangif te gedaan. 
Door verschillende oorzaken (21) is hier sprake van een onderrapportage. Staphylococcus aureus, Clostridium perfringens en Bacillus cereus zijn de belangrijkste veroorzakers van bakteriële voedselvergiftiging. Voor een uitvoerige bespreking van de kenmerken van deze voedselvergiftigingen wordt verwezen naar de publikaties van Huisman (21), Snydham (24) en Schneider (25). Volledigheidshalve dient hier de in Nederland zeer zeldzame vorm van voedselvergiftiging, veroorzaakt door het door de Clostridium Botulinum gevormde toxine, het botulisme, genoemd te worden.

\subsection{Reizigersdiarree}

In een beschouwing over acute diarree kan niet worden voorbij gegaan aan de reizigersdiarree. De hoge incidentie, 30 tot 50\%, van de reizigers maakt er in min of meer ernstige vorm kennis mee, tezamen met het toegenomen reizigersverkeer heeft ertoe geleid, dat het acute gastro-enteritis syndroom, optredend tijdens een verblijf in het buitenland, het onderwerp van vele studies was en is (26-36).

Reizigers naar (sub)-tropische landen, die afkomstig zijn uit landen met een goede faecale hygiëne, zijn in het bijzonder gevoelig voor reizigersdiarree. Meestal in de tweede week na aankomst ontwikkelt zich het beeld van een acute gastro-enteritis met diarree, buikkrampen, misselijkheid en braken en in ongeveer $10 \%$ van de gevallen, koorts (31). De duur van het ziektebeeld beperkt zich in de meerderheid van de gevallen tot 3 à 5 dagen (26).

De meeste gevallen van reizigersdiarree worden veroorzaakt door bakteriën; minder frekwent zijn virussen of parasieten de oorzaak. Besmet voedsel, dranken en drinkwater brengen de infektie over. De meeste van de in tabel 1.2. vermelde micro-organismen 
zijn beschreven als oorzaak van reizigersdiarree, echter de meest voorkomende verwekkers zijn enterotoxine-producerende Escherichia Coli stammen $(26,32)$, die bij éénderde van de gevallen worden aangetoond.

Voor de preventie van reizigersdiarree staan drie benaderingen open $(26,28)$ : hygiënische aanbevelingen t.a.v. voedsel- en drankgebruik, vaccinatie en het profylactisch gebruik van respektievelijk niet-antimicrobiële en antimicrobiële middelen. Strikte aanbevelingen ten aanzien van voedsel- en drankgebruik zijn niet altijd gemakkelijk op te volgen en het effekt ervan op de incidentie kon niet worden aangetoond (33). Bruikbare vaccins zijn niet beschikbaar, zodat veel studies zich richten op het effekt van profylaxe. Een profylactisch effekt van niet-antimicrobiële middelen, zoals absorberende kool, tanalbumine en loperamide is niet aangetoond. Met het profylactische gebruik van doxycycline, trimethoprim of trimethoprim sulfamethoxazol kon een belangrijke reduktie (van 808) van reizigersdiarree worden verkregen $(34,37)$. Het profylactisch gebruik van antibiotica wordt in de literatuur $(26,28)$ echter ontraden; de nadelen van mogelijke bijwerkingen en resistentie-ontwikkeling wegen zwaarder dan de voordelen. Dit te meer daar snelle behandeling met glucose-zout-oplossingen ("oral rehydration solution") per os, gekombineerd met een antiperistaltisch medicament (bv. Loperamide) of in ernstiger gevallen in kombinatie met trimethoprim-sulfamethoxazol, de klachten snel doet verdwijnen.

Het fenomeen van de reizigersdiarree heeft nog eens benadrukt, dat Escherichia coli, bekend als een bakterie behorend tot de residente darmflora, eveneens een belangrijke oorzaak is van darminfekties $(38,39)$. De diarree-veroorzakende E.coli-stammen worden in een 5-tal groepen onderscheiden (40); elke groep wordt gevormd door meerdere stammen, die per groep te onderscheiden zijn met 
behulp van serotypering. De pathogenese van de diarree is voor elke groep verschillend, evenals het ziektebeeld. Onderscheiden worden de:

- enterotoxische E.COLi (ETEC): diarree door deze stammen wordt veroorzaakt door onder meer de produktie van een cholera-achtig enterotoxine. De stammen behorend tot deze groep zijn, zoals besproken, dikwijls de verwekker van reizigersdiarree. In ontwikkelingslanden worden ETEC-stammen veelvuldig als verwekkers bij acute diarree gevonden. In de Westerse wereld zijn deze stammen waarschijnlijk zelden de oorzaak van acute diarree.

- enteropathogene E.coli (EPEC): stammen behorend tot deze groep, vroeger aangeduid met Coli Bray, zijn beschreven als de oorzaak van de gevreesde epidemisch optredende diarree bij zuigelingen (41). Een door deze stammen gevormd cytotoxine, dat grote overeenkomst toont met een toxine geproduceerd door Shigella dysenteriae type 1, speelt een belangrijke rol bij de pathogenese $(39,42)$. EPEC epidemieën komen om niet geheel duidelijke redenen slechts zelden meer voor.

- enterovasieve E.Coli (EIEC): penetratie van de enterocyt overeenkomstig de pathogenese bij Shigelia-infektie, staat bij EIEC-stammen op de voorgrond. De infektie veroorzaakt een dysenterie-achtig beeld met een exudatieve diarree (43).

- enterohaemorrhagische E.coli (EHEC): stammen behorend tot deze groep zijn beschreven als de oorzaak van haemorrhagische colitis bij kinderen en zuigelingen. Het haemolytisch-uraemisch syndroom met infekties wordt door EHEC-stammen in verband gebracht (40).

- enteroadherente E.coli (EAEC): tot deze groep worden een aantal bij epidemieën geisoleerde stammen gerekend, die geen van de pathogene mechanismen van de genoemde groepen vertonen. De groep is nog slecht gedefiniëerd en waarschijnlijk heterogeen (40). 
De betekenis van deze verschillende E.coligroepen als verwekkers van acute diarree is mede door de speciale en bewerkelijke laboratorium-diagnostiek - niet goed bekend. Waarschijnlijk is deze in endemische omstandigheden gering.

1.6. Bakteriële oorzaken van diarree.

In deze paragraaf wordt in het kort ingegaan op de meest voorkomende bakteriële oorzaken van acute diarree. Voor een uitgebreide behandeling van deze en andere bakteriële oorzaken wordt verwezen naar de literatuur $(44,45,46)$.

\subsubsection{Salmonel lose}

Van de in Nederland voorkomende voedselinfekties wordt het merendeel veroorzaakt door bakteriën van het geslacht salmonella (zie tabel 1.4.). De Samonellae worden serologisch ingedeeld in een groot aantal serotypen. Deze indeling is mogelijk omdat bij de salmonellae twee antigenen voorkomen, het somatisch o-antigeen en het flagellaire H-antigeen, die beide in verschillende antigene-varianten voorkomen. De mogelijkheid een groot aantal serotypen - er zijn er meer dan 3000 beschreven - te onderscheiden, is vooral voor de epidemiologie van belang.

Een voor kliniek en epidemiologie bruikbare en praktische indeling is die, welke gebaseerd is op ziektebeeld en gastheer-specificiteit. S.typhi en S.paratyphi B komen respektieveiijk uitsluitend en vrijwel uitsluitend bij de mens voor en veroorzaken een ernstig "typheus" ziektebeeld. De "overige" Salmonellae komen bij het dier voor en besmetten de mens via het voedsel. Het ziektebeeld, de Salmonellose, is dat van een acute gastro-enteritis. Een tussenpositie wordt ingenomen door de $\mathbf{s . c h o l e r a e s u i s . ~ D e z e ~ b i j ~}$ 
varkens voorkomende Salmonella veroorzaakt bij de mens sepsis en metastatische abcessen. Een Salmonella-infektie bij het dier verloopt meestal symptoomloos. Het dier blijft drager. De belangrijkste dierlijke Salmonella-dragers $z i j n$ het varken en de kip $(47,48)$. Vanuit het dierlijk reservoir vindt via het voedsel een voortdurende besmettingsdruk plaats. De incidentie van salmonellosen is over de jaren dan ook vrij konstant (figuur 1.6.1.). Per jaar treedt een duidelijke seizoenstop op in zomer en nazomer.

FIGUUR 1.6 .1 .

Salmonelta, incidentie per 100.000 inwoners, $1953-' 84$

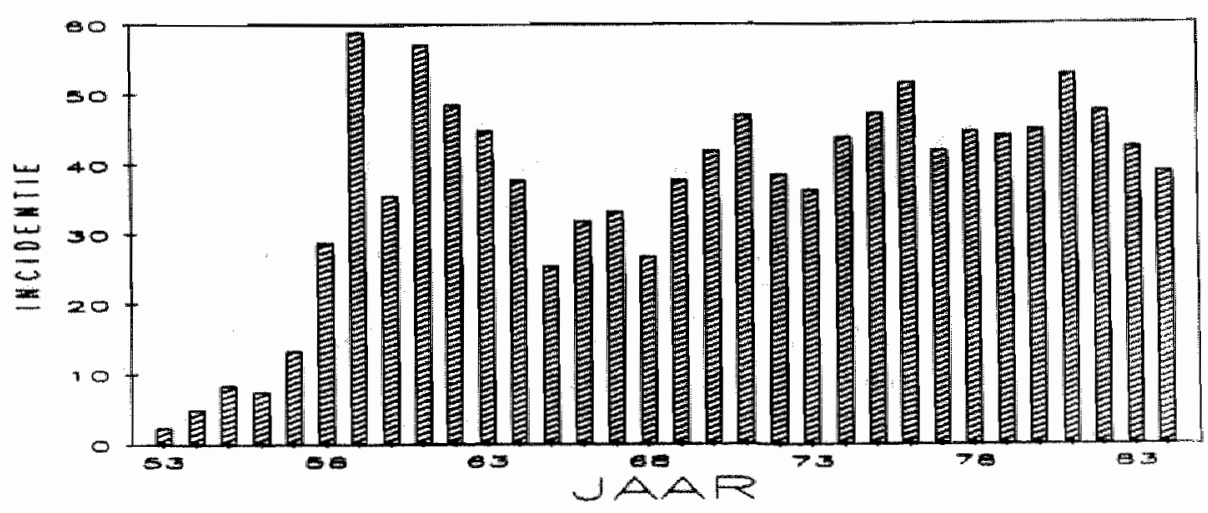

* Bron: Geneeskundige Hoofdinspektie van de Volksgezondheid. Per 1 januari 1985 is de aangifteplicht vervallen.

Besmetting van de mens vindt bijna uitsluitend plaats via besmet voedsel en zelden door besmet water. Directe en indirecte kontaktbesmetting door faecal-orale overdracht of besmetting door huisdieren kan indien de omstandigheden gunstig zijn, optreden $(49,50$, 51).

Het klinisch beeld van Salmonellosen varieert van een a-symptomatische infektie, via een milde gastro-enteritis tot het beeld van een 
ernstige enterocolitis $(52,53)$. Een gegeneraliseerde infektie met sepsis en sekundaire gelokaliseerde infekties kan voorkomen bij verminderde afweer, zoals bij jonge zuigelingen (54), oudere of immuun gekompromiteerde patienten.

\subsubsection{Shigellose}

Bakteriële dysenterie of Shigellose is een acute darminfektie bij de mens, veroorzaakt door bakteriën behorend tot het geslacht. Shigella. Biochemisch zijn 4 soorten te onderscheiden, Shigella dysenteriae, Shigella flexneri, Shigella boydil en Shigella sonnei, die elk verder zijn onder te verdelen in éen of meer serotypen.

Sh. sonnei is inheems in Nederland; infekties met Sh.flexneri zijn meestal die met de andere Shigellae bijna zonder uitzondering, import $(55,56)$. Besmetting vindt plaats door direct of indirect faecaal-oraal kontakt, slechts zelden met voedsel; de besmettingsdosis is laag. Sh.sonnei-infekties worden dan ook vooral daar gezien waar uitbreiding door faecaal-oraal kontakt gemakkelijk kan optreden, zoals in crèches, kleuterscholen, verpleegtehuizen e.d. In deze instellingen kan Sh.sonnei endemisch voorkomen. Door de faecaal-orale besmettingsweg treedt ook gemakkelijk verbreiding in het gezin op, vooral bij kleine kinderen (56).

Infekties met Sh.sonnei kunnen variëren van a-symptomatisch of licht verlopende (gastro-lenteritis, tot het beeld van de dysenterie, met heftige buikkrampen en diarree met bloed- en slijmbijmenging.

\subsubsection{Campylobacteriose.}

Na de eerste isolatie in 1972 van Campylobacter uit faeces (57) en de toepassing van verbeterde isolatie-technieken (58) is de 
betekenis van dit micro-organisme als verwekker van acute gastro-enteritis bij de mens snel toegenomen $(59,60,61,62,63,64,65)$.

Tabe 1 1.4. toont dat Campylobacter een goede tweede is bij voedselinfekties. Twee soorten, Campylobacter jejuni en Campylobacter fetus veroorzaken het merendee van de infekties $(62,66)$.

Campylobacteriose is evenals de salmonellose een zoönose en ook de epidemiologie toont grote overeenkomsten met die van salmonellainfekties. Hoewel Campylobacter wijd verbreid bij dieren voorkomt, vormen geinfekteerde kippen de belangrijkste besmettingsbron $(61,62,67)$ en besmetting vindt vooral plaats door besmet kippevlees.

Het klinisch beeld variëert ook bij Campylobacteriose sterk in symptomatologie. In het merendeel van de infekties begint de ziekte met algemene malaise, waarna zich een acute gastro-enteritis ontwikkelt met koorts, buikkrampen en waterdunne diarree. Bloed- en slijmbijmengingen wordt bij ongeveer de helft van de patienten beschreven. Meestal treedt een herstel op na 4 tot 7 dagen. Soms ontwikkelt zich een ernstige enterocolitis die enige weken kan aanhouden.

\subsubsection{Yersiniose}

Yersiniose, veroorzaakt door de Yersinia enterocolitica, is eveneens een zoönose die de mens bereikt via besmet dierlijk voedsel. Besmetting via vlees, vooral varkensvlees (68), is regel; zeldzamer zijn besmettingen door geïfekteerde huisdieren (69), drinkwater (70) of melk (71). Twee serotypen, 3 en 9. worden in Nederland en België het meest aangetroffen.

Klinisch verloopt een Yersinia-infektie als een acute gastro-enteritis met koorts (72). Meestal is het verloop onschuldig en vindt 
spontane genezing binnen 2 weken plaats; in een aantal gevallen is er sprake van langer durende klachten met diarree van 2 weken tot enkele maanden. Bij kinderen kan de heftige buikpijn een appendicitis nabootsen $(73,74)$. Gewrichtsklachten kunnen in aansluiting op een Yersinia-infektie optreden $(75,76)$.

In tabel 1.6.5. zijn, bewerkt naar het overzicht gegeven door Wolf (77), de belangrijkste kenmerken van de vier besproken bakteriële oorzaken van acute gastro-enteritis samengevat. 


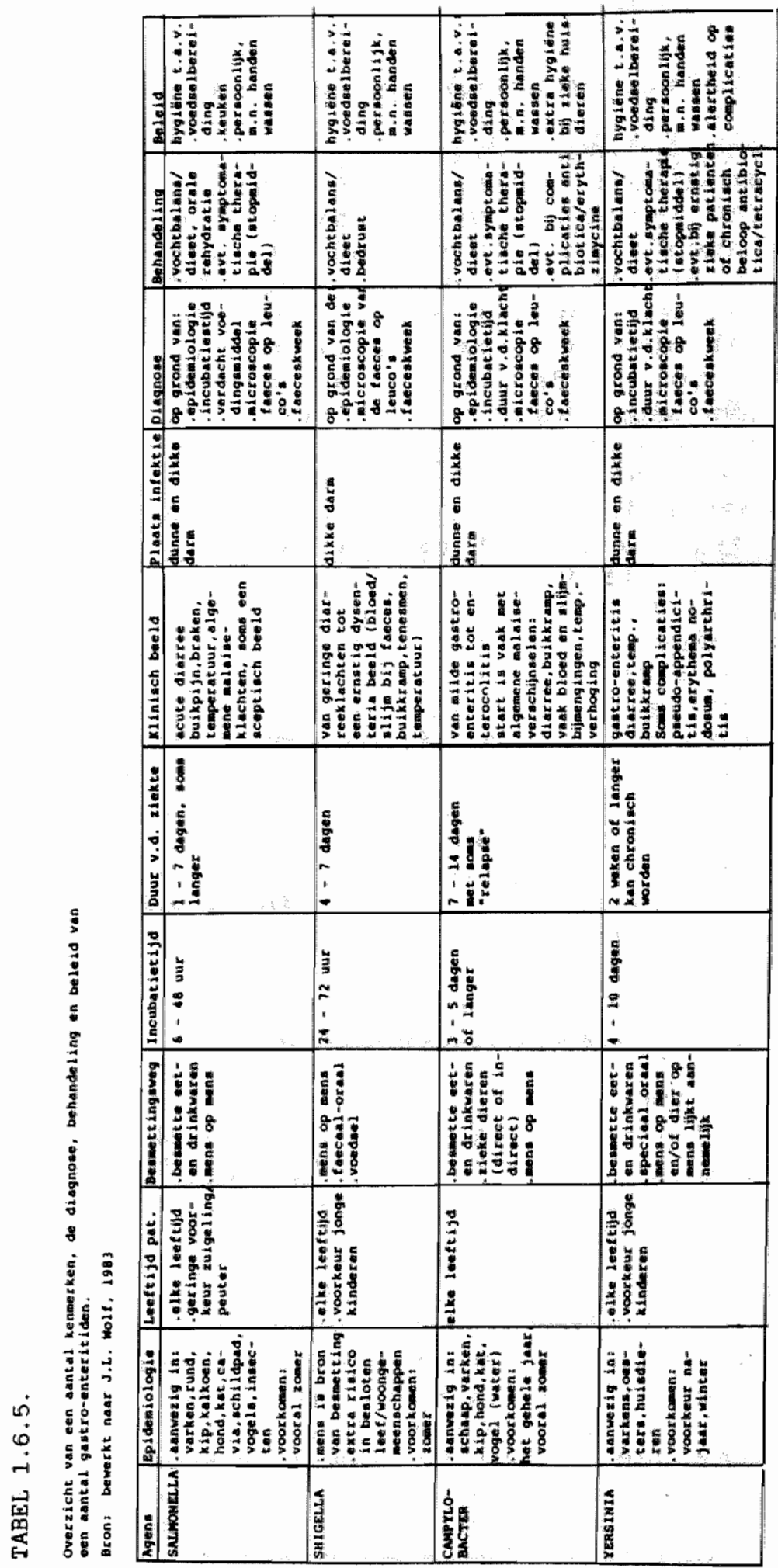


Het verhoudingsgewijs groot aantal bakterieel en parasitair onverklaarde gevallen van acute diarree leidde al vroeg tot het vermoeden dat "virussen" deze infekties veroorzaakten. De aanvankelijke veronderstelling dat enterovirussen (poliomyelitis-, Coxsackie- en Echovirussen) hiervoor verantwoordelijk waren is op grond van epidemiologisch onderzoek verworpen. De ware virale etiologie van deze gastro-enteritiden is pas ontdekt door direct elektronenmicroscopisch onderzoek van faeces. De toepassing van deze en andere methoden, warmee virusdeeltjes of virale antigenen direct in de faeces worden aangetoond, heeft geresulteerd in de beschrijving van een verscheidenheid aan virussen, die bij de mens acute gastro-enteritis kunnen veroorzaken. De virussen zijn niet of zeer moeilijk met de bekende, klassieke virologische methoden te isoleren, maar wel direct in de faeces aantoonbaar. Voor een beschrijving van de ontwikkeling in de laatste 15 jaar en de huidige inzichten wordt verwezen naar een aantal recente publikaties $(15,78,79,80)$. Hier worden in het kort een aantal van deze nieuwe virussen besproken. De belangrijkste kenmerken van twee van deze virussen, het Rota- en Norwalkvirus zijn weergegeven in Tabel 1.7.1.

Met zekerheid is aangetoond, dat het rotavirus, het norwalkvirus en twee typen adenovirus bij de mens acute gastro-enteritis veroorzaken. Infekties met deze virussen zijn wereldwijd een veel voorkomende oorzaak van acute diarree zowel endemisch als in de vorm van kleine en grote epidemische verheffingen. op de kinderleeftijd is het rotavirus waarschijnlijk de meest voorkomende oorzaak van gastro-enteritis. Incidenties variërend van 30-60\% zijn beschreven bij zuigelingen van 6-24 maanden $(80,81,82)$. Bij oudere kinderen en volwassenen verlopen de infekties milder en komen waarschijnlijk minder vaak voor. Toch is ook bij volwassenen Rotavirus niet 
zelden oorzaak van ziekte (83). Ook reizigersdiarree wordt niet zelden door Rotavirus veroorzaakt. Bij ouderen boven de 70 jaar nemen zowel de incidentie als de ernst van het ziektebeeld mogelijk weer toe.

Rotavirusinfekties komen in de gematigde klimaatzônes vooral in de wintermaanden voor. De wintertop zou er op kunnen wijzen, dat naast de faecaal-orale route, verspreiding met behulp van druppeltjes door de lucht kan plaatsvinden ( 84 ).

$\mathrm{Na}$ het doormaken van een infektie ontstaan antilichamen. Het merendeel van de kinderen boven de 2 jaar en volwassenen bezitten neutraliserende antilichamen. Van het rotavirus zijn verschillende serotypen bekend. De immuniteit is evenwel heterotypisch; na infektie met één serotype worden ook antilichamen reagerend met een ander type gevormd. De immuniteit is echter partieel en beschermt waarschijnlijk slechts kortdurend tegen een infektie in de darm. Immuniteit beinvloedt wel het ziektebeeld; de infektie verloopt subklinisch of mild.

Vaccinatie-studies $(85,86)$ geven eenzelfde beeld; vaccinatie beschermt niet tegen infektie, het ziektebeeld wordt slechts in gunstige zin beinvloed.

Het Rotavirus, tezamen met serologisch verwante Rotavirussen van dierlijke oorsprong, wordt gerekend tot de groep A, Rotavirussen. Recent (87) zijn serologisch niet met groep A verwante virussen beschreven. Eén van deze met groep $B$ aangegeven Rotavirussen zou, hoewel minder frekwent dan van groep A Rotavirus, gastro-enteritis bij voornamelijk volwassenen veroorzaken.

Elektronenmicroscopisch zijn in faeces bij acute diarree een grote verscheidenheid aan morfologisch verschillende virusdeeltjes waargenomen. Een groep van morfologisch identieke maar in andere opzichten waar- 
schijnlijk verschillende virusdeeltjes wordt aangeduid als "small round viruses". Het eerst beschreven en meest bestudeerde "small round virus": is het Norwalk-virus. Het virus heeft een wereldwijde verbreiding (88) en veroorzaakt in tegenstelling tot het Rotavirus vooral bij oudere kinderen, volwassenen acute gastro-enteritis. Besmetting met het virus langs faecaal-orale weg vindt waarschijnlijk dikwijls plaats, zoals blijkt uit de aanwezigheid van antilichamen bij meer dan tweederde van de volwassenen. Hier doet zich echter immunologisch een paradoxe situatie voor. Een klinische infektie treedt juist op bij diegenen, waarbij antilichamen gevormd zijn of worden. Immuniteit geeft dus geen of een zeer beperkte bescherming. Het is duidelijk dat de ontwikkeling van een vaccin weinig vooruitzichten biedt.

Twee serotypen, de typen 40 en 41 , van de adenovirussen veroorzaken bij de mens acute gastro-enteritis. Deze twee adenovirussen zijn, in tegenstelling tot de andere adenovirussen niet op celkweken te isoleren, hoewel in de faeces bij acute gastro-enteri$t i s$ grote aantallen virusdeeltjes elektronenmicroscopisch zijn aan te tonen. Bij het ziektebeeld staat de acute diarree op de voorgrond: braken, koorts en andere symptomen komen minder frekwent voor dan bij Rotavirusinfekties.

De epidemiologie van deze adenovirussen toont grote overeenkomst met die van het Rotavirus; infekties komen vooral voor bij zuigelingen en kinderen. In deze leeftijdsgroep zijn de adenovirussen na het Rotavirus de tweede belangrijke oorzaak van gastro-enteritis (89). Het voorkomen van een seizoensgebondenheid zoals bij rotavirus kon niet worden vastgesteld $(90)$.

De betekenis van een aantal eveneens bij acute diarree aangetoonde virussen is minder duidelijk. Van Calicivirussen (91). Astrovirussen (92) en andere zogenoemde "small 
round viruses" is aannemelijk, dat deze bij de mens acute gastro-enteritis veroorzaken; de epidemiologische betekenis van deze virussen is echter onzeker. Een verband tussen het voorkomen van corona-achtige virusdeeltjes en acute gastro-enteritis is niet bewezen. 


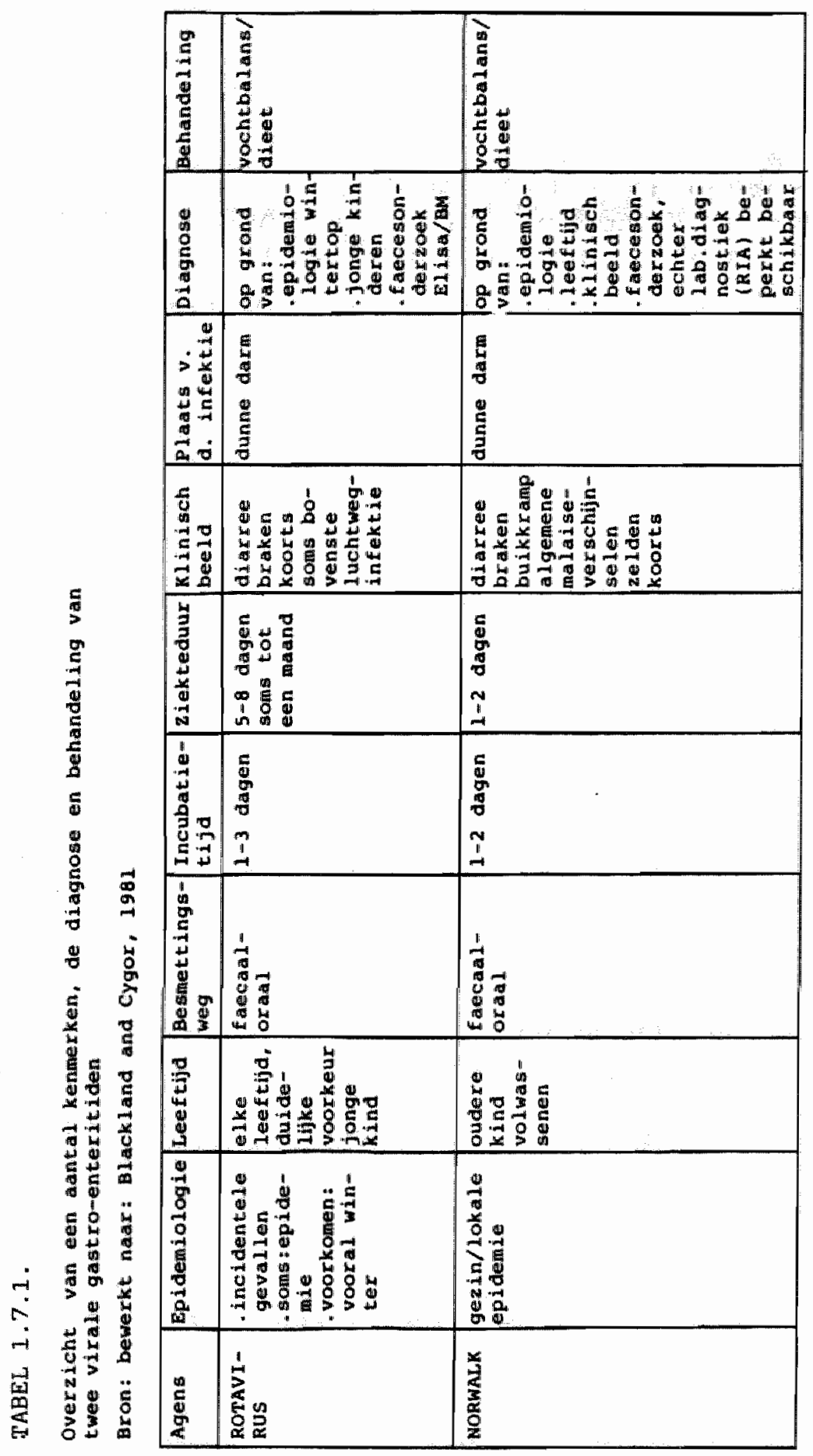


1.8. Parasitaire oorzaken van diarree.

In Nederland is het aantal gevallen van acute diarree veroorzaakt door parasieten, gering. Amoebiasis veroorzaakt door Entamoeba histolytica is vrijwel zonder uitzondering verkregen in de (sub-)tropen en dient bij reizigersdiarree als één van de mogelijke oorzaken overwogen te worden.

Giardiasis (Lambliasis) veroorzaakt door Giardia intestinalis is een voornamelijk bij kinderen voorkomend ziektebeeld waarvoor eerder een chronische malabsorptie diarree kenmerkend is dan het beeld van acute diarree. Een uitzondering hierop is de reizigersdiarree veroorzaakt door Giardia intestinalis: een massale besmetting door faecaal verontreinigd drinkwater veroorzaakt een heftig, acuut gastro-intestinaal syndroom.

Cryptosporidium is de derde protozoaire parasiet die als mogelijke oorzaak van acute diarree genoend moet worden. Cryptosporidiosis werd tot voor kort beschouwd als een beroepsziekte van dierenartsen en dierenhandelaren. Door het intensieve kontakt vond besmetting plaats met de in de faeces uitgescheiden oocyten van de bij veel diersoorten voorkomende Cryptosporidium (93). Recent is aangetoond, dat Cryptosporidium bij immun gekompromiteerde AIDS-patienten heftige diarree kan veroorzaken (94).

Prevalentie-studies verricht in immuunkompetente populaties toonden vervolgens aan dat Cryptosporidium meer voorkomt dan werd vermoed (95). Aangenomen wordt, dat de besmetting door faecal-oral kontakt wordt overgebracht (96), maar besmetting door faecaal verontreinigd water is eveneens beschreven (97).

ook reizigersdiarree kan door een Cryptosporidiuminfektie worden veroorzaakt (98).

De juiste prevalentie van Cryptosporidiosis als oorzaak van acute diarree is nog onvoldoende bekend (99); een eerste studie (100) 
doet vermoeden dat slechts een paar procent van de acute diarree bij kinderen hieraan kan worden toegeschreven.

\subsection{Konklusie}

Uit het bovenstaande, in het kader van dit proefschrift noodzakelijkerwijs beknopt gehouden literatuuroverzicht, is af te leiden dat de epidemiologie (incidentie, seizoen- en leeftijdgebondenheid) en klinisch beeld (symptomatologie en type diarree) van acute diarree een aantal indikatoren verschaft, bruikbaar voor etiologische diagnostiek. De beschreven betrekkelijke specificiteit van de relatie microbiële verwekker en klinisch beeld zal echter de bruikbaarheid hiervan beperken. Het in dit proefschrift beschreven onderzoek stelt zich ondermeer tot doel de predictieve waarde van een aantal van deze indikatoren te toetsen in de situatie van de huisartspraktijk. De in het onderzoek verkregen epidemiologische gegevens over het vóórkomen van microbiële oorzaken van acute diarree in de huisartspraktijk verschaft eveneens de mogelijkheid de vraag te beantwoorden in hoeverre deze gegevens overeenkomen met die, verkregen op basis van de vigerende aangifteplicht. 
HOOFDSTUK 2 : HANDELEN VAN DE HUISARTS, EEN LITERATUUROVERZ ICHT

\subsection{Inleiding}

Bij de zorgverlening van de huisarts aan de patient met acute diarree zijn verschillende aspekten te onderscheiden.

In dit hoofdstuk wordt ingegaan op de waarde van de ziektegeschiedenis en aan de betekenis van een lichamelijk onderzoek.

Aan de orde komen verder het gebruik van laboratoriummogelijkheden door de huisarts bij deze klacht, de therapeutische mogelijkheden waarbij het aksent op de medikamenteuze benadering ligt en tenslotte wordt ingegaan op de mogelijkheden en de noodzaak van maatregelen ter voorkoming van uitbreiding van incidentele gevallen.

\subsection{Anamnese}

De klacht acute diarree presenteert zilch zeer vaak in kombinatie met braken (45\%), buikpijn $(408)$, koorts $(30 \%)$ en algemene malaise-verschijnselen (1).

Bij dit symptomenkompleks, ook wel aangeduid met acute gastro-enteritis, maar ook bij diarree als het enige symptoom, is voor de huisarts de meest relevante vraag: Is er sprake van een niet-ernstige of van een potentieel ernstige klacht? of: is dit een eenvoudige gastro-enteritis of is er iets bijzonders aan de hand? of nog weer anders gesteld: kan er volstaan worden met een dieetvoorschrift, waarna de klacht vanzelf wel overgaat na enige dagen, of moet er een andere actie ondernomen worden en op welke bijzondere zaken moet gelet worden?

Voor de beantwoording van deze vragen zal de huisarts nagaan welke gegevens hem reeds ten dienste staan en welke hij nog moet vergaren. Ten eerste beschikt hij doorgaans over zgn. "voorkennis". Hij kent het gezin van de pa- 
tient, weet veelal waar de patient werkt, woont, wat het beroep is en kent de medische voorgeschiedenis. Acute gastro-enteritis is vooral een gezinsdiagnose $(2,3)$ en het is aannemelijk dat de huisarts in zijn handelen met deze voorkennis rekening zal houden. Niettemin is het toch de vraag in hoeverre hij gebruik makkt van deze informatie of er werkeiijk de beschikking over heeft. In de huisartspraktijk zullen niet telkens bij een op het eerste gezicht eenvoudige klacht alle gegevens worden geraadpleegd. Veel zal a fhangen van wat de huisarts zich op het moment van het kontakt met de patient herinnert van diens voorgeschiedenis. Dit geldt zeker wanneer de doktersassistente de patient te woord staat en, in een kort overleg met de huisarts, vraagt wat zij kan doen.

Deze procedure is voor wat deze klacht betreft niet ongebruikelijk in de huisartspraktijk.

Tijdens de huisartsgeneeskundige konferenties in Nijmegen 1980 (4) over het onderwerp akute gastro-enteritis bleek, dat een groep van 22 huisartsdeelnemers geen afdoend schema van vragen kon opstellen.

Er werden allerlei onsamenhangende vragen gesteld. Het ging hierbij om vragen als: hoe lang? hoe vaak? welke kleur? bloed of slijm erbij gezien? koorts aanwezig? iets verkeerds gegeten? zijn er meerdere personen in de ongeving met diarree? recentelijk op reis geweest? etc. Dok ten aanzien van de doktersassistente, die een niet onbelangrijk deel van deze klacht te horen krijgt via de telefoon of aan de receptiebalie, bestond geen bruikbare instruktie of werkschema, terwijl de wens daartoe door de deelnemers uitdrukkelijk werd uitgesproken.

Hennink 1978 (5) verzamelde via een enquete in 15 huisartspraktijken, behorend tot de "perifere kliniek" van het Leidse Instituut voor Huisartsgeneeskunde, gegevens over welke vragen bij de klacht acute diarree in het algemeen tijdens het eerste huisarts-patientkontakt worden gesteld. In Maastricht en om- 
streken werd in het kader van de voorbereiding op deze studie in 1983 een enquete gehouden onder 34 huisartsen, waarbij o.m. gegevens over ditzelfde onderwerp werden verzameld.

Tabel 2.2 .1 geeft de resultaten van beide enquetes weer.

TABEL 2.2 .1

Anamnestische * vragen bij de klacht acute diarree

Leiden $(\mathrm{N}=15)$ Maas-

$(N=34)$

tricht

n $\quad 8 \quad n \quad 8$

duur van de klacht 15 frekwentie

14

100

93

24

18

71

konsistentie ont-

lasting

aspekt van de ont-

lasting

14

93

11

53

koorts

11

73

30

32

pijn

gewichtsverlies

14

93

21

88

10

$66 \quad 16$

62

1

6,6

47

aard van de voe-

ding

10

66

22

65

verblijf in buiten-

land

diarree in de omge-

ving

7

46

10

29

10

66

18

53

geneesmiddelenge-

bruik

psychosociale fak-

toren

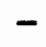

1

* Bron: Hennink Huisarts en Praktijk 1978, Leiden (5)

Maastricht 1983 (eigen onderzoek)

- = geen opgave

Beide enquête-uitslagen laten niet op alle kenmerken een vergelijkbaar patroon zien. Vragen over gewichtsverlies, geneesmiddelengebruik, psychosociale faktoren en een verblijf 
in het buitenland worden niet als routine gesteld. Moeilijker wordt de interpretatie van de gegevens t.o.v. de overige kenmerken. Enig verschil in belangrijkheid bestaat er ten aanzien van vragen over de duur, het voorkomen van koorts. In de Leidse enquête gaven de huisartsen de voorkeur aan vragen over frequentie en konsistentie, terwijl uit de Maastrichtse enquête bleek, dat dergelijke vragen van minder importantie werden geacht. De vraag naar het aspekt van de ontlasting werd evenwel in Maastricht belangrijker geacht dan in Leiden. Het is niettemin opmerkelijk, dat op twee verschillende plaatsen in Nederland met een tijdspanne van 5 jaar dezelfde kenmerken in de anamnese bij de klacht acute diarree zijn terug te vinden.

Uit de gegevens van de Maastrichtse enquête bleek verder, dat iets meer dan een kwart van de patienten met acute diarree in eerste instantie met de doktersassistente de klacht afhandelde.

Satterwhite en Dupont 1983 (6) vinden de vraag naar medicijngebruik een belangrijke eerste vraag. Vooral antibiotica en eetlustremmers zijn volgens hen bekende oorzaken van diarree. De huisarts zou tevens vragen dienen te stellen over eigen medicijngebruik van de patient, m.n. stopmiddelen en laxantia en over het bestaan van eigen diëten als regulier voedingspatroon (gezondheidsvoedsel, kruidenthee, dieetmaltijden e.d.).

Wolf 1983 (7) stelt dat, als een patient klaagt over diarree, de eerste vragen zouden moeten gaan over de frekwentie, de hoeveelheid, het aspekt van de ontlasting (bloed en/of slijm) en over een mogelijke samenhang met het eten. Het antwoord op deze vragen zou een richtsnoer kunnen zijn t.a.v. de aard van de verwekker en mogelijk tevens van invloed op het handelen van de arts. Zo zou een volumineuze waterige diarree een aanwijzing kunnen zijn voor een enterotoxigene E.Coli of vibrio cholera (alhoewel dit laatste micro-organisme in onze streken vrijwel nooit wordt aangetrof- 
fen). Bloed bij de ontlasting duidt volgens Wolf meer op een bakteriële of parasitaire infektie en vrijwel niet op een virale oorsprong. Dees 1984 (8) stelt, dat patroonherkenning een belangrijke bijdrage kan zijn bij het stellen van een diagnose. Intermitterende diarree komt voor bij lactase deficiëntie, postgastrectomie, coloncarcinoom, irritable bowel syndrome en bij diabetische neuropathie. Nachtelijke diarree zou weer tegen een irritable bowel syndrome pleiten. Arthralgieën in kombinatie met diarree kunnen een sein zijn voor chronische darmontstekingen en voor sommige infektieziekten als Campylobacteriose en Yersiniose.

Uit het voorafgaande wordt duidelijk, dat er een nogal verschillende interpretatie van de anamnese bestaat bij de diverse auteurs. Het ligt voor de hand, dat bij artsen het verschil in benaderingswijze te maken zal hebben met de plaats die zij innemen in het gezondheidszorgsysteem .

Opvallend is, dat de huisartsen uit de Nijmeegse konferentiegroep niet in staat waren een afdoend werkschema op te stellen, terwijl andere auteurs, die medisch specialist zijn, vrij nauwkeurig kunnen aangeven wat de voornaamste anamnestische vragen zouden moeten zijn. De vraag kan gesteld worden of de min of meer specialistische benadering wel van toepassing kan zijn op het ongedifferentiëerd patientenaanbod van de huisartspraktijk.

In dit verband is het zinvol extra aandacht te besteden aan specifieke onderdelen van de anamnese met het oogmerk meer aanwijzingen te verkrijgen over oorzaak c.q. verwekker, teneinde er in het beleid rekening mee te kunnen houden.

Voedse1

Indien de gastro-enteritis zich presenteert zonder koorts en binnen enkele uren na konsumptie van voedingsmiddelen, komen toxine producerende bakteriën als stafylococcus 
aureus en Bacillus cereus en clostridium difficile in aanmerking. Komt er wel koorts voor en is deze bovendien intermitterend van karakter dan komen salmonella, Shigella, Campylobacter en Yersinia meer in het vizier. Van deze verwekkers is shigella een zeer infektieus organisme en een snel uitbreidende infektie binnen bepaalde leeftijdsgroepen (zeer jonge kinderen, bejaarden) kan eventueel als hulpmiddel voor een diagnose dienst doen. Niet typheuze salmonellose kan zich bij alle leeftijdsgroepen voordoen en kan door allerlei voedingsmiddelen worden overgebracht, met als voornaamste bron vlees, m.n. kippevlees. vibrio parahaemolyticus bereikt de mens doorgaans via schaal- en schelpdieren.

ook niet bakteriële agentia kunnen via het voedsel of (drink)water darminfekties veroorzaken. Giardia Lamblia veroorzaakt vaak diarree die soms lang aanhoudt en meestal zonder koorts. Entamoeba histolytica infekties vertonen doorgaans naast diarree lichte koorts en bloed bij de faeces. Ook Rotavirus en vertegenwoordigers van de Norwalkgroep kunnen via deze route diarree met koorts veroorzaken.

\section{Seizoen}

In landen met een gematigd klimaat zouden in de wintermaanden vooral Yersinia enterocolitica en virussen een belangrijke bron zijn. Salmonella en Shigella bereiken juist in de zomermaanden een hoogtepunt. Ook Campylobacteriose zou in de zomer een seizoenspiek hebben. Wolf 1983 (7) merkt t.a.v. de seizoensinvloeden op, dat de tijd van het jaar nooit definitief het voorkomen van een bepaald infektieus agens kan uitsluiten.

Buitenlandse reizen

Hierbij staat de reizigersdiarree voorop met de enterotoxigene $\mathbf{E}$.Coli als voornaamste vertegenwoordiger, alhoewel vele andere micro-organismen hetzelfde ziektebeeld kunnen veroorzaken (zie ook hoofdstuk 1.5). 
Reizigers uit (sub)tropische streken m.n. uit de ontwikkelingslanden hebben een verhoogde kans een infektie met Giardia Lamblia of Shigella te krijgen.

Huisdieren

De indruk bestaat dat de vraag of de infektie van (zieke) huisdieren afkomstig kan zijn in de anamnese nogal eens wordt overgeslagen. Katten, honden (m.n. puppies) kunnen echter een belangrijk reservoir vormen voor onder meer Campylobacter (9).

Bijkomende klachten

Het bestaan van een bovenste luchtweginfektie bij de klacht diarree kan een belangrijk gegeven zijn. Dergelijke symptomen worden nogal eens in verband gebracht met een Rotavirus of Shigella infektie.

Arthralgieën en erythema nodosum zouden weer meer voorkomen bij Yersiniose en Campylobacteriose.

Sexuele anamnese

Zowel Satterwhite en Dupont 1983 als Wolf 1983 $(6,7)$ leggen de nadruk op de sexuele anamnese bij de klacht diarree.

Zij stellen, dat vooral personen met homosexuele relaties en/of hetero-sexuele relaties met oraal/anale technieken meer kans hebben op het verkrijgen van virale/bakteriële/parasitaire infekties dan gewoonlijk in een algemene populatie voorkomt.

Met betrekking tot deze groepen mag het verkregen Immuno deficientie syndroom (AIDS) niet onvermeld blijven. Aanhoudende diarree is naast huid-, longafwijkingen, gewichtsverlies, algemene malaise en koorts een bekend symptoom.

Vooral bij patienten, behorende tot de risikogroepen, die dergelijke verschijnselen tonen, dient de huisarts alert te zijn op het bestaan van AIDS, alhoewel de bevindingen bij de 
anamnese en lichamelijk onderzoek zelden pathogmonisch voor het syndroom zijn. Dit betekent, dat bij deze patienten het opstellen van een differentiaal diagnose van het grootste belang is, voordat verder laboratoriumonderzoek wordt verricht (10).

Er is nog een belangrijke faktor in de anamnese, die het gedrag van de huisarts ten aanzien van de klacht acute diarree in hoge mate bepaalt en dat is het gevaar voor uitdroging. m.n. bij zuigelingen en bejaarden. Op dit verschijnsel wordt iedere arts tijdens zijn opleiding bij herhaling gewezen. De huisartsen in de Nijmeegse konferentiegroep stelden, dat zij dit probleem in feite toch mar betrekkelijk weinig in de praktijk tegenkwamen. Een aantal huisartsen meende, dat bij een telefonische konsultatie vragen over de defaecatiefrekwentie al dan niet gekombineerd met braken, het al of niet geregeld plassen van de patient (aantal natte luiers bij de zuigeling) en hoe aktief de patient is, anamnestisch toch een zekere indruk kunnen geven over de aan- of afwezigheid van het dehydratiegevaar. Anderen in de groep vonden dat men nooit af kon gaan op de antwoorden op deze vragen en wilden altijd de patient zelf zien.

Samenvattend kan worden gesteld, dat voor de huisarts de anamnese een zodanige informatie zou moeten verschaffen, dat het hem mogelijk wordt in relatief korte tijd te kunnen inschatten: Hoe ziek is de patient? Met welke oorzaak heeft men te doen? en Welke aktie is nodig?

\subsection{Lichamelijk onderzoek}

Bij het lichamelijk onderzoek is de algemene indruk, onder meer via de anamnese verkregen, van groot belang. De mate van uitgebreidheid van het onderzoek door de huisarts zal sterk afhangen van deze algemene indruk. 
Hennink 1978 (5) vroeg in zijn enquête niet alleen naar het wel of niet verrichten van lichamelijk onderzoek bij patienten met acute diarree tijdens het eerste arts-patient kontakt, maar ook naar de uitgebreidheid ervan. ook in de Maastrichtse enquête werden gegevens verzameld met betrekking tot dezelfde vraag. Tabel 2.3.1 toont de resultaten van deze enquêtes.

TABEL 2.3 .1

Lichamelijk onderzoek bij acute diarree

\begin{tabular}{|c|c|c|c|c|c|c|}
\hline & $\begin{array}{l}\text { Leiden } \\
\text { wel } \\
\text { n }\end{array}$ & $\begin{array}{l}(N=15) \\
\text { soms } \\
n\end{array}$ & $\begin{array}{l}\text { niet } \\
\mathrm{n}\end{array}$ & $\begin{array}{l}\text { Maastri } \\
\text { wel } \\
\mathrm{n}\end{array}$ & $\begin{array}{l}\text { cht }(N \\
\text { soms } \\
\text { n }\end{array}$ & $\begin{array}{l}=34 \text { ) } \\
\text { niet } \\
\text { n }\end{array}$ \\
\hline $\begin{array}{l}\text { algemeen } \\
\text { onderzoek }\end{array}$ & 1 & 1 & 13 & & - & - \\
\hline $\begin{array}{l}\text { onderzoek } \\
\text { van de } \\
\text { buik }\end{array}$ & $8(538)$ & $5(338)$ & $2(148)$ & $28(82 \%)$ & $2(68)$ & $4(12 \%)$ \\
\hline $\begin{array}{l}\text { rectaal } \\
\text { toucher }\end{array}$ & 0 & 6 & 9 & - & 3 & - \\
\hline
\end{tabular}

* Bron:Hennink 1978, Leiden (5)

Eigen onderzoek 1983 Maastricht.

** - = niet gevraagd

In de Mastrichtse enquete werd door 8 huisartsen expliciet vermeld, alleen algemeen lichamelijk onderzoek te verrichten bij kinderen en dan nog in het bijzonder als er problemen op het gebied van de kNo en of aanwijzingen voor uitdroging waren.

Hennink rapporteert, dat het geringe aantal lichamelijke onderzoeken door de huisartsen wordt gemotiveerd met een opmerking over het kortdurende en onschuldige karakter van de diarree. Zowel Hennink 1978 (5) in zijn enquête als van de Lisdonk 1980 (4) via de Huisartsgeneeskundige konferentie te Nijmegen vermelden een verschuiving van geen onderzoek 
naar wel onderzoek bij persisteren van de klacht (en).

Bij het onderzoek zijn vooral de leeftijd en het gevaar voor dehydratie belangrijke kriteria voor het handelen. Bij kinderen kan een onderliggende infektie oorzaak zijn van de klacht acute diarree. Vooral neusverkoudheid, otitis, bronchitis, urineweginfekties en zelfs een meningitis en pneumonie zijn in deze leeftijdsgroep bekende oorzaken, terwijl een pneumonie ook bij de bejaarden aan de orde kan zijn. Van de Lisdonk 1980 (4) rapporteert dat het beoordelen van de turgor door de Nijmeegse konferentiegroep moeilijk en onbetrouwbaar werd gevonden.

In het algemeen is tijdens buikonderzoek bij auscultatie bij de meeste patienten met acute diarree een versterkt darmgeruis waar te nemen. Het abdomen is over het algemeen gevoelig voor palpatie en er zijn doorgaans geen pathologische weefsel weerstanden palpabel, tenzij er sprake is van een intra abdominaal proces. Om diezelfde reden is rectaal toucheren bij bejaarden van belang ( 8 ), vooral bij patienten met een voorgeschiedenis van obstipatie (paradoxe diarree).

\subsection{Laboratorium-diagnostiek}

Er staat de huisarts een redelijk aantal laboratoriumtesten ter beschikking om achter de mogelijke oorzaak van de diarreeklacht te komen.

Hennink 1978 (5) meldt uit zijn onderzoek in de "Leidse perifere kliniek", dat vrijwel niemand van de huisartsen in eerste instantie onderzoek verricht, van zowel bakteriologische, serologische of röntgenologische aard.

Tijdens de huisartsgeneeskundige konferenties in Nijmegen 1980 werd de diskussie over de zin van het laboratoriumonderzoek bij acute diarree in een breder kader geplaatst. 
Als kernvraag werd geformuleerd: Wat is het doel van je beleid?

Men stelde, dat het beleid van de huisarts gericht dient te zijn op het voorkomen van uitaroging, het vermijden van eventuele besmetting en verspreiding van de ziekte.

De groep huisartsen vond, dat als deze doelen werkelijk aan de orde zijn, laboratoriumonderzoek weinig zinvol is vanwege de hoge mate van besmetting en verspreiding van micro-organismen (bv. Salmonella) onder het slachtvee. Aldus de leden van deze konferentiegroep.

Daarbij komt nog, dat kennis hebben van het bestaan van een invasieve bakteriële besmetting bij personen, werkzaam in de open levensmiddelenindustrie, het handelen van de huisarts in preventief opzicht niet gemakkelijker maakt.

Betrokken personen kunnen gedupeerd worden door de eventuele matregelen, terwijl de epidemiologische drijfveer ter diskussie staat.

Van der Does 1984 (11) vindt het kweken bij acute diarree een weinig zinvolle bezigheid, tenzij men een epidemiologisch onderzoek nastreeft om na te gaan wat er in de populatie aan darminfekties omgaat, maar zelfs dan vreest hij dat de oogst gering zal zijn.

Meer aandacht zou gegeven kunnen worden aan het bestaan van klinische predictoren voor een positieve kweek. In een onderzoek in het Massachusetts General Hospital (12) werd in een jaaropbrengst van bakteriologische kweken $(\mathrm{N}=2468)$ in 2,48 groei van een bakterieel micro-organisme vastgesteld. Een combinatie van persisterende diarree (langer dan 24 uur), met koorts (hoger dan $37,8 \mathrm{C}$ ) met óf bloed (occult) of buikpijn met misselijkheid en braken bestond bij $40 \%$ van de mensen met een positieve kweek en bij geen van de patienten met een negatieve kweek.

Een ander aspekt bij het laboratoriumonderzoek is het observeren van de faeces.

Hennink 1978 (5) stelt, dat huisartsen maar 
zelden de faeces onder ogen krijgen en afgaan op mededelingen van de patient. Gill 1978 (13) deed een onderzoek in drie huisartspraktijken naar de "normale defaecatie". ongeacht de leeftijd kijkt ongeveer $19 \%$ niet naar de faeces, warbij de reële mogelijkheid daartoe m.b.t. een vlakspoeltoilet versus een diepspoeltoilet buiten beschouwing is gelaten. Gelet op deze gegevens behoort de huisarts volgens Gill bij vragen naar konsistentie, kleur, bijmengingen in wezen gedwongen te worden, de patient te vragen een specimen in te leveren.

Het microscopisch onderzoek naar leucocyten in de faeces vindt niet meer plaats in het eigen laboratorium van de huisarts. Toch zijn er vele publikaties die het belang ervan onderstrepen $(6,7,14)$.

Het is een eenvoudige test, die snel verricht $k a n$ worden en $b i j$ een positieve bevinding een aanwijzing kan zijn dat er sprake is van een ontstekingsreaktie in het colon en/of een invasie van micro-organismen. Dat zou een reden kunnen zijn tot kweken.

\subsection{Behandeling.}

Bij de behandeling van een eenvoudige gastroenteritis is in het algemeen een dieet even eenvoudig als effektief en aanvullende medikatie is zelden noodzakelijk (4). Meestal wordt gestart met een carentieperiode van 6-8 uur. De duur van deze periode is arbitrair ; ten aanzien van zuigelingen en kleine kinderen is een dergelijke vastenperiode minder aanbevelenswaardig.

Deze patientjes kan men beter een verdunde of zure voeding geven om vervolgens na enkele dagen geleidelijk terug te keren naar een normale voeding.

De Nijmeegse konferentiegroep (4) stelt, dat de eerste dag na de carentieperiode begonnen kan worden met frekwente kleine hoeveelheden vocht met elektrolyten eventueel aangevuld met 
glucose. Genoemd werden: thee, bouillon, gekookt water met wat zout en glucose, mineraalwater.

Er werd aanbevolen geen vast voedsel te geven op de eerste dag, en geleidelijk te beginnen met rijst, beschuit, magere yoghurt, banaan, in het algemeen aangeduid als lichte kost en vervolgens langzaam op te klimmen naar het gewone eetpatroon. Bij het mislukken van deze regels zou behalve bij zuigelingen en zeer jonge kinderen geadviseerd kunnen worden weer van voren af aan te beginnen.

In de recente literatuur (15) ligt de nadruk bij de behandeling van acute diarree vooral op de vocht-toevoer ter kompensatie van het verlies van water en elektrolyten en op farmaca die de obstipatie stimuleren en/of de secretie afremmen. De rehydratie moet vooral praktisch zijn en oraal kunnen worden toegediend. Orale rehydratie wordt sinds 7 jaar op grote schaal toegepast. Het is een goedkope therapie gebleken, die ongeacht de verwekker kan worden toegepast.

Door de world Health organisation werd rehydratievloeistof gepropageerd voor de behandeling van ernstige diarree-patienten (zie tabel 2.5.1). De verhouding suiker-zout is erg belangrijk. De juiste formule is 20 gram glucose (of $20 \mathrm{gram}$ gewone suiker) en $3,5 \mathrm{gram}$ zout op één liter water.

Ook voor de minder ernstige patienten is deze vloeistof als orale therapie zeer goed van toepassing. 
TABEL 2.5 .1

Samenstelling van orale rehydratiesolutie (ORS) in $\mathrm{mEq} / 1 ; \mathrm{gr} / 1$ en in lepels.

Samen-

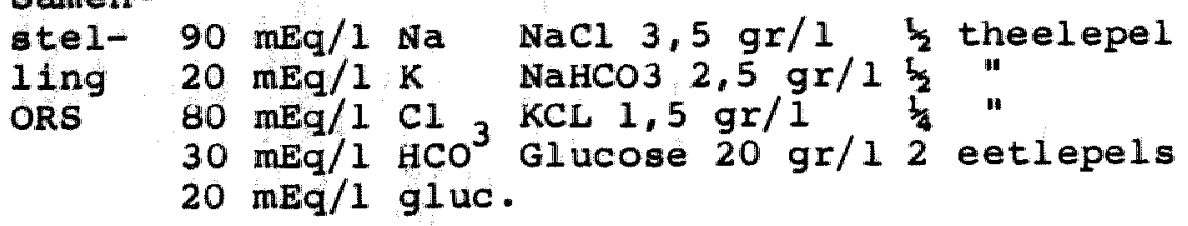

Bron: World Health Organisation

Het hoge Na-gehalte en daardoor het gevaar van een hypernatriaemie wordt nogal eens als bezwaar aangevoerd tegen deze samenstelling. Uit een studie van Santosham 1982 (16) e.a. is te leren, dat toediening van orale glucoseelektrolyt oplossingen met resp. $50 \mathrm{mEq} / \mathrm{l} \mathrm{Na}$ en $90 \mathrm{mEq} / \mathrm{l} \mathrm{Nat}$ bij goed gevoede gehospitaliseerde kinderen met acute diarree (tussen de 3 maanden en 2 jaar) een veilige behandeling is. Voorhoeve 1984 (17) stelt dat het fundamenteel is om glucose toe te voegen, omdat daardoor de resorptie van water en zout maar liefst 20 à 25 keer bevorderd wordt. Tevens stelt hij het van essentieel belang te vinden dat direkt wordt begonnen bij iedere vorm van diarree en spugen en dat er geen carentieperiode wordt ingelast.

Van der Does 1984 (11) heeft niet zo' $n$ behoefte aan "dure" mengsels: 1 liter water, 8 theelepels suiker en 1 theelepel zout geeft een bruikbaar eigen maaksel.

Fliers e.a. $1984(18)$ doen verslag van een voorbeeld van "verkeerde zuinigheid" met betrekking tot de samenstelling van een orale rehydratie-oplossing door de ouders op advies van de huisarts. In plaats van hun dochtertje van 17 maanden een oplossing te geven waaraan 1 theelepel zout was toegevoegd, werd 1 eetlepel per liter toegevoegd. Het patientje begon dezelfae dag nog te braken en ging geleidelijk achteruit. De huisarts konstateerde een ern- 
stige dehydratie en liet het kind opnemen.

Er kunnen t.a.v. de juiste samenstelling problemen ontstaan in de bereiding van het mengsel, zelfs bij standaardoplossingen. Fliers e.a. stellen voor gebruik te maken van een sachet, waraan alleen maar water moet worden toegevoegd.

Ten aanzien van het dieet speelt er nog een probleem. Door het ontbreken van enzymen in de borstelzoom van een enterocyt bij vele vormen van diarree kan er sprake zijn van een passagere lactase-deficiëntie. Het is daarom aanbevelenswaard geen melk in het dieet toe te laten, totdat de ontlasting weer enige vaste vorm heeft aangenomen.

In die gevallen, waarbij de frekwentie van de diarree een niet acceptabele vorm gaat aannemen m.n. voor de dagelijkse bezigheden, is farmacotherapie zinvol. Tot voor kort was er volgens Matti 1984 (19) hoofdzakelijk aandacht voor de prikkeloverdragende stoffen van het autonome zenuwstelsel en wel het cholinerge deel en dan nog maar voor één werking m.n. de beinvloeding van de motoriek door middel van de anticholinerge stoffen, b.v. atropine. Deze stoffen remmen de versterkte motoriek bij diarree, hetgeen niet wil zeggen dat de diarree ook primair het gevolg was van deze verhoogde motoriek of van een cholinerge aktiviteit.

Tal van lichaamseigen stoffen hebben een duidelijke invloed op een of meer funkties van de darm. Het vasoactive intestinal peptide speelt mogelijk een rol bij de cholinerge prikkeloverdracht. Endorfinen kunnen de motoriek en de secretie beinvloeden, waarschijnlijk niet als prikkeloverdragers maar als modulatoren van het effekt van de zenuwprikkels.

Van der Meer 1987 (20) e.a. onderscheidt onder meer de volgende symptomatisch werkende middelen:

Anticholinergica of parasympathicolytica of antispasmodica 
Deze groep heeft als groot nadeel het zeer brede werkingsmechanisme en ze moet in zo hoge doseringen gegeven worden, dat de "bijwerkingen" het beoogde effekt overheersen. Met name zijn glaucoom en urineretentie niet goed voorspelbare gevaren, die vooral de bejaarden treffen, juist een leeftijdsgroep die voor farmacotherapie in aanmerking zou kunnen komen.

\section{Darmadstringentia}

Deze zouden de invloed van toxische prikkels op de darmucosa verminderen.

Vertegenwoordigers van deze groep zijn de tannine derivaten (tannalbumine) en niet resorbeerbare basische bismuthverbindingen. voor alle bismuthverbindingen bestaat het gevaar van resorptie en dus van intoxicatie. Dupont 1977 (21) e.a. evalueerden het gebruik van Bismuth subsalicylaat (Pepto Bismol) onder studenten die een Mexicaanse universiteit bezochten voor een zomerkursus. Hij vond in dit "double blind" opgezette onderzoek een duidelijke vermindering van de defaecatiefrekwentie in de onderzoeksgroep t.o.v. de placebogroep. Vooral bij de diarree veroorzaakt door enterotoxigene E.Coli stammen was dit effekt het meest waarneembaar.

Pickering 1983 (22) stelt, dat dit middel misschien van enige waarde zou kunnen zijn bij epidemieèn, doch dat er in feite geen publikaties voorhanden zijn waarin wordt aangetoond, dat het bij patienten met diarree gerechtvaardigd is.

\section{Darmabsorbentia}

Hiertoe behoort absorberende kool, als voornaamste vertegenwoordiger. De indruk bestaat, dat dit middel mede vanwege de vrije verkoop de "drug of choice" is voor wat de eigen medikatie van de patient betreft. Deze stof kan water en toxinen absorberen en vermindert de diarree, doordat er wat meer gevormde ontlas- 
ting wordt geproduceerd. Toch bestaan er geen "controlled studies", die een beperking van de duur of vermindering van water- en elektrolyten-verlies kunnen aantonen. Noordhoek Regt e.a. 1984 (23) stellen dat de effektiviteit van aktieve kool het grootste is bij zo spoedig mogelijke toediening. Als het toxine al in de cel gefixeerd is, kan het niet meer door de aktieve kool verwijderd worden. Preventief gebruik is het meest effektief en kwaad doet het niet, want het is een volgens deze auteurs volkomen onschadelijk middel. Een nadeel van het gebruik van aktieve kool is, dat tevens voedselbestanddelen, enzymen en antibiotica worden geabsorbeerd, vooral als er sprake is van langdurig gebruik.

Een andere niet onbelangrijke bijkomstigheid van het gebruik van koolprodukten is het gegeven dat deze middelen de faeces zwart kleuren, hetgeen de huisarts tot extra aandacht voor de anamnese noopt.

De Nijmeegse konferentiegroep ontraadt het gebruik van Norit, Tannalbumine e.d.

\section{Opi umderivaten}

De meest werkzame stopmiddelen bij diarree behoren tot deze groep. Deze stoffen verhogen de spiertonus in de darm en verminderen daardoor de motiliteit. Vooral het oude tinct. opii crocata lijkt nog immer bij een juiste dosering een betrouwbaar, goedkoop en effektief middel $(4,19)$. Loperamide (Imodium) bezit een grote mate van therapeutische veiligheid en vertoont geen op opium gelijkende centrale effekten.

De werking van dit middel is nog niet geheel duidelijk. Loperamide vermindert net zoals codeine de vochtsecretie, voornamelijk door werking op de motorische funktie van de darm (15).

De Nijmeegse huisartsengroep ontraadt nu juist weer dit middel alhoewel er onder de groepsleden een aantal waren die loperamide, niet voor het tinct. opii croc. zouden willen inruilen. Ewe 1983 (24) ziet het dyphenoxylaat (Reasec) 
en loperamide als duidelijke verbeteringen op het tinct. opii croc. Hij stelt dat loperamide bij orale toediening geen werking heeft op het czs en dat het ook nog een zekere mate van secretieverminderende eigenschappen zou hebben.

Als nadeel kan worden aangevoerd, dat loperamide het uitscheiden van pathogene kiemen mogelijk vertraagt, waardoor het ziektebeloop ongunstig beinvloed kan worden.

Antibiotica

Voor het gebruik van antibiotica in de huisartspraktijk bij patienten met een acute gastro-enteritis bestaat eigenlijk geen indikatie. Een uitzondering kan wellicht bestaan bij patienten, waarbij de ziekte een bijzonder (ernstig) beloop heeft. Antibiotica kunnen door verstoring van de natuurlijke flora van de tractus digestivus de diarree verergeren. Daarbij komt het gevaar voor resistentie, dat voor de diverse organismen zeer verschillend is $(25)$.

Nelson e.a. 1980 (26) rapporteerden uit een prospektief onderzoek bij kinderen met een Salmonella enteritis die met of een antibiotica of een placebo behandeld waren, het volgende:

Een opleving van de diarree werd alleen waargenomen in de groep die met antibiotica was behandeld.

zij konkludeerden dat het gebruik van penicilline-derivaten geen voordeel had bij patienten met een gewone Salmonella enteritis. Uit een vroeger gedateerd onderzoek van Askerhof en Bennett 1969 (27) bij twee groepen patienten met acute Salmonella gastro-enteritis bleek dat 11,58 van hen die geen antibiotica-therapie hadden gekregen na 31 dagen nog een positieve faeces kweek toonden, terwijl voor de groep die wel antibiotica voorgeschreven kreeg, dit percentage $27 \%$ bedroeg. Helaas zijn er bij dit onderzoek geen gegevens vastgelegd over de leeftijden van de patienten. Nye 1981 (28) formuleert uiterst voorzichtig 
op basis van experimenten bij muizen dat antibiotica de uitscheiding van Samonella zouden kunnen verlengen.

Pickering 1983 (22) stelt dat antimicrobiële agentia niet routinematig gebruikt moeten worden bij acute diarree of gastro-enteritis van onbekende oorzaak.

Een uitzondering zou gemaakt kunnen worden bij patienten met ernstige ziekteverschijnselen of wanneer er sprake is van komplikaties en/of het personen betreft met een verlaagd afweermechanisme.

Tenslotte kan worden vermeld, dat tot op dit moment geen specifieke antimicrobiële agentia bekend zijn, die als effektief kunnen worden beschouwd bij virale gastro-enteritis veroorzaakt door Rota-, Norwalk-, Adeno-virussen.

\subsection{Beleid}

Door de positie die de huisarts in de gezondheidszorg inneemt, heeft hij een centrale rol in gezondheldsvoorlichting en opvoeding van zijn patienten. Als gezinsarts is hij doorgaans goed op de hoogte van de leefomstandigheden van de patient of kan gegevens hieromtrent vrij gemakkelijk vergaren.

In het algemeen zullen maatregelen door de huisarts ter voorkoming van uitbreiding van incidentele gevallen van acute gastro-enteritis zich beperken tot het geven van adviezen met betrekking tot de hygiëne.

De relatie tussen gastro-enteritis en voedsel wordt vaak niet eerder vermoed dan wanneer er sprake is van een explosie in het gezin (meer dan 2 gevallen). Het vermoeden bestaat dat adviezen in zulke gevallen vaak beperkt blijven tot opmerkingen over goed de handen wassen bij de toiletgang en in het bijzonder bij de berelding van voedsel. Het onvoldoende verhitten van voedsel echter, het bewaren bij onvoldoende snel bereikte lage tempteraturen van (diepvries-) vleesprodukten en het gevaar van kruisbesmetting in de keuken zijn de 
voornaamste faktoren van uitbreiding van de besmetting.

Ten aanzien van patienten met een infektieuze gastro-enteritis, die beroepshalve betrokken zijn bij het bereiden of verpakken van eet- en drinkwaren, behoort een werkverbod tot het besmettingsgevaar zeer klein is tot de overwegingen in het advies van de huisarts. Vooral wanneer het gaat om personen, die patienten verplegen of verzorgen is een werkverbod sterk aan te bevelen.

De eventuele konsekwenties voor de detaillist in een dergelijk advies zullen een belangrijke faktor vormen en dienen te worden afgewogen tegen de epidemiologische gevolgen.

Van deze algemene maatregel kan de huisarts afwijken, wanneer het gaat om een symptoomloze uitscheider van Salmonella (met uitzondering van S.Typhi en S.paraTyphi), werkzaam in een slagerij of slachthuis. Vooral varkensvlees, blijkt reeds in hoge mate gecontamineerd te zijn met salmonellae bij binnenkomst op de plaats van verwerking en vormt daardoor een veel groter risiko dan de Salmonella uitscheider zelf.

Vaccinaties tegen micro-organismen die diarree veroorzaken zijn in de huisartspraktijk beperkt tot Typhus en Cholera. Sinds kort is de noodzaak tot cholera-vaccinaties sterk afgenomen.

Het is volgens Hennesy 1981 (29) gezien de overeenkomst tussen het choleratoxine en het thermolabiele (LT) enterotoxine van enterotoxigene escherichia coli (ETEC) mogelijk dat levend choleravaccin ook een beschermend effekt heeft tegen LT stammen van ETEC (reizigersdiarree).

Op een konferentie in Maryland in 1985 (30) over reizigersdiarree werd in de slotkonklusies opgenomen, dat vooralsnog in de komende jaren geen bruikbare vaccins beschikbaar zouden komen.

Bij kinderen is het m.b.t. het Rotavirus te verdedigen een vaccinatie tegen dit virustype in te voeren. 
Met betrekking tot een verwijzing $c . q$. opname zal de huisarts eerder op klinische dan op bakteriologische gronden een beslissing nemen. Als indikatie kunnen de noodzaak tot parenterale rehydratie en tekenen van sepsis worden beschouwd. Patienten met gelijktijdig bestaande ernstige ziekten kunnen ook onder deze noemer gerekend worden. Bij zuigelingen zal de algemene toestand en het feit dat daarin bij acute diarree snel een verslechtering kan optreden, het beleid ten aanzien van verwijzen c.q. opname bepalen.

Het advies aan de patient of diens verzorger: "Zie maar, ik hoor wel als het niet goed gaat" hetgeen in de huisartspraktijk nogal eens gegeven wordt, is volgens van der Does (11) volstrekt onjuist.

\subsection{Nabeschouwing.}

In dit hoofdstuk zijn de voornaamste aspekten van de zorgverlening van de huisarts aan een patient met acute diarree ter sprake gekomen. De anamnese is zonder meer een belangrijk instrument bij de diagnostiek, doch de indruk bestaat dat de anamnesevragen veelal afkomstig of direkt afgeleid zijn van klinische situaties en niet uit het werkterrein van de huisarts.

De specialist ziet een geselekteerde patient en zal m.b.v. de anamnese vooral op zoek gaan naar de oorzaak van de klacht.

De huisarts heeft een ongeselekteerd patientenaanbod en de mogelijkheid bestaat, dat hij met dezelfde anamnese tot een niet gelijkluidende interpretatie komt.

Een aantal aanbevelingen zijn te geven, met betrekking tot de bruikbaarheid van de anamnese bij patienten met acute infektieuze diarree in de huisartspraktijk.

Ten eerste kan de duur van de klacht in relatie met het voedsel van belang zijn: acuut optredende ziekteverschijnselen, misselijk- 
heid, braken, diarree, korte tijd (1-6 uur) na het konsumeren van eet- of drinkwaren geven een sterke aanwijzing voor een voedselvergiftiging. Stafylococcen (staphylococcus aureus) hebben dit vaak op hun geweten.

Een ander niet minder klassiek en ernstig ziektebeeld is het botulisme, dat in ons land bij de mens maar zeer weinig voorkomt. Minder duidelijk wordt het wanneer de tijdsspanne groter is. Of er dan sprake is van een microbiële verwekker, blijft vaak ongewis. Toch moeten vele gevallen van gastro-enteri$t i s$, die vaak worden afgedaan als buikgriep, worden toegeschreven aan voedselvergiftigingen of voedselinfekties.

Een tweede kenmerk van belang is de koorts. Temperatuurverhoging geeft doorgaans niet alleen een toename van het ziektegevoel, maar zou een aanwijzing voor een infektieuze diarree kunnen zijn.

Verder nemen vragen in de anamnese naar het voorkomen van bloed en slijm een belangrijke plaats in. Het vermoeden met een bakteriële of parasitaire oorzaak te doen te hebben ligt hier waarschijnlijk aan ten grondslag. of er een verband bestaat tussen deze twee zaken bij patienten met acute diarree in de huisartspraktijk is nog maar zeer de vraag en wordt in deze studie nader onderzocht.

Vragen naar het gebruik van geneesmiddelen, door de patient, hetzij verkregen via een prescriptie, hetzij zelf gekocht, zijn in de anamnese op de achtergrond geraakt.

Een ander belangrijk punt in de anamnese bij een telefonische konsultatie zijn de vragen die inzicht kunnen geven over het gevaar van uitdroging. De frekwentie van de defaecatie, het voorkomen van braken, zijn hiervoor waardevolle beoordelingsinstrumenten, als niet alleen volstaan wordt met het noteren van het aantal malen, maar ook een indruk verkregen wordt van de hoeveelheden vocht die verloren gaan. Met name bij kleine kinderen is de po een bruikbare mat. 
Kinderen vormen bij de klacht acute diarree een aparte groep. Een acute gastro-enteritis, veroorzaakt door een enterale of parasitaire infektie komt op de kinderleeftijd frekwent voor. Daarbij komt dat dehydratie voor de zuigeling, peuter en kleuter een levensbedreigende zaak kan zijn. Het is dan ook voor de huisarts van het grootste belang bij kinderen met acute diarree, te kunnen beoordelen of het kind een zieke indruk maakt of niet. Een niet ziek kind heeft hoogst zelden een diarree-klacht die zo ernstig is dat er gevaar is voor ernstig vochtverlies. Een ziek kind daarentegen, heeft vaak een enterale of parenterale oorzaak voor zijn klacht en het gevaar voor uitdroging is zeer reëel. Niet alleen de diarree of het braken spelen hierbij een rol, maar ook het vochtverlies via transpiratie.

Het onregelmatig defaeceren van een borstkind wordt vaak ten onrechte als een stoornis (bv. als diarree) geduid. Een zogende moeder die veel fruit eet of laxantia gebruikt kan bij haar borstkind een frekwente defaecatie veroorzaken.

Tenslotte zijn er nog twee faktoren in de anamnese, die de huisarts behulpzaam kunnen zijn bij beoordeling van de diarree-klacht. Ten eerste het belang van de patroonherkenning, met name bij patienten met een ernstige ziekte.

Ten tweede de herkomst van de patient, m.n. de reiziger- c.q. tourist uit (sub-)tropische en mediterrane streken, die de huisarts kan konfronteren met importziekten.

De importantie van het lichamelijk onderzoek bij acute diarree ligt voornamelijk in het beoordelen van hydratietoestand van de patient d.m.v. de turgor. Vooral wanneer patienten een zieke indruk maken is dit een onmisbaar onderzoek-gegeven. Telefonische adviezen aan patienten of instrukties aan doktersassistenten zouden tegen deze achtergrond moeten worden opgesteld. 
Laboratoriumonderzoek is bij een niet zieke patient met diarree niet zinvol. Een faeceskweek bij een patient met een zieke indruk zou te overwegen zijn om vroegtijdig infektieuze diarree op het spoor te komen. Adviezen ter voorkoming van de verspreiding van incidentele gevallen kunnen dan gericht gegeven worden. Bovendien zou de huisarts in geval van een explosie, vooral in gesloten woon- of leefgemeenschappen, onnodig tijdverlies m.b.t. de kweekuitslag kunnen voorkomen.

Het zwaartepunt van de behandeling van de klacht acute diarree is gelegen in de vochttoevoer. Ongeacht vele in gebruik zijnde symptomatische therapieën staat het onmiddel$1 i j k$ herstellen van de vochtbalans bij vooral patienten die een zieke indruk maken centraal. Bij een goede instruktie door de huisarts is het een even effectieve als goedkope maatregel. (31) 
HOOFDSTUK 3 : METHODE VAN ONDERZOEK

3.1. Opzet van het onderzoek.

Van september 1983 tot oktober 1984 werd in 25 huisartspraktijken in de stad Maastricht en omstreken een onderzoek verricht naar de klacht acute diarree.

Ten behoeve van dit onderzoek werden de 25 huisartspraktijken gestratificeerd naar de kenmerken solo/nonsolopraktijk en stad/omgeving en vervolgens ad random verdeeld over twee groepen A en B. Dit was nodig, omdat in een van de doelstellingen van dit onderzoek de vraag lag opgesloten of er een juist beeld is te verkrijgen van het voorkomen van mikrobiële agentia bij de klacht acute diarree indien dat gebaseerd is op de uitkomsten van faeceskweken, zoals die normaliter door huisartsen worden aangevraagd. Het vragen om een faecesmonster van alle patienten die zich met acute diarree tot de huisarts wenden, zou de beantwoording van bovenbedoelde vraag onmogelijk maken. Om deze reden werden er in dit onderzoek twee groepen huisartspraktijken gehanteerd.

In groep A werden door zowel de huisartsen als de doktersassistentes van alle patienten met acute diarree een faecesmonster ter kweek naar het laboratorium van het Academisch Ziekenhuis Maastricht (voorheen St. Annadal) gestuurd.

Dit betekende: ongeacht of de huisarts de aanvraag geïndiceerd vond: altijd kweken

In groep $B$ werden door de huisartsen enkel op indikatie een faecesmonster ter kweek opgestuurd.

Dit betekende: de normale gang van zaken.

3.2. Keuze van de praktijken

Bij de start van het onderzoek bedroeg de totale groep huisartsen behorende tot het verzorgingsgebied van het Diagnostisch centrum 
van het Academisch Ziekenhuis Mastricht 65 , werkzaam in 49 praktijken (zie figuur 1 ).

Aan vrijwel alle huisartsen in dit gebied werd een verzoek tot deelname gericht.

37 huisartsen en hun doktersassistentes, werkzaam in 25 praktijken, gaven hun fiat aan het verzoek tot deelname.

20 huisartsen reageerden negatief, waarbij deelname aan een ander projekt of het medisch onderwijs als belangrijkste oorzaak werd opgegeven.

8 huisartsen werden niet benaderd, daar zij reeds eerder kenbaar hadden gemaakt in het algemeen niet aan onderzoek te willen deelnemen.

De praktijken van de deelnemende huisartsen toonden een zodanig karakter, dat de voor de vraagstelling relevante kenmerken in voldoende mate aanwezig waren, zodat de kans op een systematische selektieve uitval bij het samenstellen van de groepen $A$ en $B$ zeer onwaarschijnlijk was.

Als relevante kenmerken werden beschouwd: de leeftijdsopbouw en de geslachtsverdeling van de patientenpopulatie in de praktijken, de geografische ligging van de praktijken in termen van stad/platteland, de organisatiegraad van de praktijken m.b.t. solo/non-solo, en behorend tot het verzorgingsgebied van het Diagnostisch Centrum van het Academisch ziekenhuis Maastricht. Van iedere praktijk werd specifiek nagegaan of er met name ten aanzien van de patientenpopulatie sprake was van een bijzondere situatie. 
FIGUUR 3.2 .1

Situering huisartspraktijken in Mastricht en ongeving

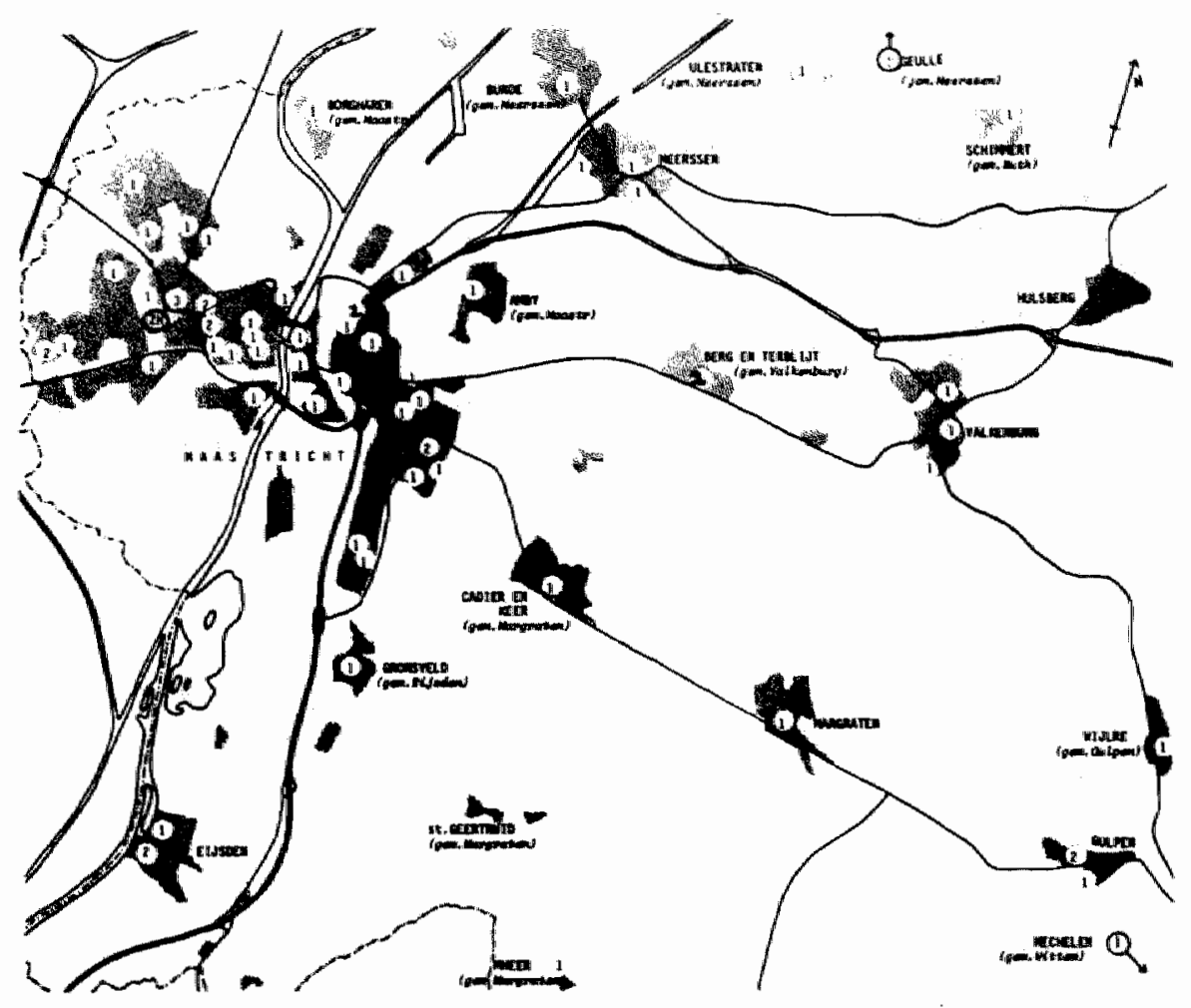

Toelichting bij de plattegrond:

$\mathrm{ZH}=$ Academisch $\mathrm{Ziekenhuis} \mathrm{Maastricht}$

1 =huisarts-solist

2 gezondheidscentrum of associatie met 2 huisartsen

3 =gezondheidscentrum met 3 huisartsen

* overgenomen uit het rapport "Diagnostisch Centrum Maastricht Eindrapportage" (1983) 
Groep A bestond uit: 1 gezondheidscentrum; 3 associaties; 7 solistenpraktijken, waarin 17 huisartsen, 15 doktersassistentes en 1 fakultaire huisarts (0.2 FTE) werkzaam waren.

Groep B bestond uit: 3 gezondheidscentra; 2 associaties en 9 solistenpraktijken, waarin 20 huisartsen en 1 fakultaire huisarts $(0.2$ FTE $)$ werkzaam waren.

Van de gezondheidscentra bevonden er zich drie ( $1 \mathrm{~A}$ en 2B) in Maastricht en één (B) in Berg en Terblijt. De associatiepraktijken waren verdeeld over viermaal ( $3 \mathrm{~A}$ en $1 \mathrm{~B}$ ) Maastricht, één (B) in Gulpen en één (A) in Eijsden. De solistenpraktijken waren terug te vinden in Maastricht en wel negen maal (4A en 5B), driemaal ( $2 A$ en $1 B$ ) in Meerssen, één (B) in Ulestraten, één (B) in Valkenburg en één (A) in Gronsveld.

Randomisatie na stratificatie kan bij kleine steekproeven toch een ongelijke verdeling geven over twee groepen. Wellicht dat in een dergelijke situatie paarsgewijze randomisatie de voorkeur geniet.

Bij het verzoek tot deelname ging het met name in de praktijken die in groep A terecht zouden komen niet alleen om een bijdrage van de huisarts, maar ook om de medewerking van de doktersassistente en de patienten. Uit een proefonderzoek, ui.tgevoerd in 5 huisartspraktijken, en uit eigen ervaring was gebleken, dat de doktersassistente een substantiëel deel van de patienten met acute diarree in of na overleg met de huisarts min of meer zelfstandig afhandelt. Om een zo groot mogelijk resultaat aan microbiële agentia te verkrijgen kon deze patientenstroom niet gemist worden.

Aan de deelnemers werd de werkbelasting uitvoerig uitgelegd. Voor participanten, die in groep A terecht kwamen, hield dit de volgende werkzaamheden in:

- het invulien van een ander (uitgebreider) 
aanvraagformulier voor meer patienten dan gewoonlijk (zie 3.4.);

- het geven van uitleg over dit onderzoek en met name over de telefonische enquete (zie 3.5.)

- het geven van instrukties aan de patient of diens begeleider over hoe met het faecesmonster gehandeld moet worden.

De totale tijdsbelasting per week werd voor de huisarts in deze groep, uitgaande van het gemiddeld voorkomen van $2-3$ patienten met acute diarree per week (1) gesteld op 30 minuten. Voor de doktersassistente kon geen gefundeerde raming gegeven worden.

voor de huisartsen, die in groep $B$ zouden terecht komen, werd de extra tijdsbellasting gering geacht. Immers in deze groep zou de normale gang van zaken worden gevolgd en er werd vanuit gegaan, dat het invullen van een uitgebreider formulier in de totale dagtaak in het niet zou vallen.

\subsection{Definitie}

Het is niet altijd duidelijk wat de patient en wat de huisarts onder diarree verstaan. Veel (huis)artsen spreken pas van diarree, wanneer er meermalen per dag waterdunne of brijige ontlasting wordt geproduceerd, terwijl sommige patienten bij een éénmalige brijige ontlasting al melden diarree te hebben.

In dit onderzoek is, uitgaande van gangbare definities in de literatuur $(2,3,4,5,6,7)$ en met behulp van het resultaat van een kleine enquete onder 10 huisartsen in de regio Maastricht, de volgende omschrijving van acute diarree gehanteerd:

- een ontlasting van waterdunne of brijige vorm

èn

- een defaecatiefrekwentie bij zowel volwassenen als kinderen van 3 of meermalen in de èn laatste twaalf uur

- niet langer bestaand dan 2 weken. 
3.4. Verzamelen van het materiaal

Aanvraag formul ier/gegevensverzamelings formulier (bijlage I en II).

Bij de opzet van dit onderzoek, dat onder meer de bedoeling had een beschrijving te geven van de zorgverlening door de huisarts aan patienten met acute diarree, stond voorop dat de hulpverlener in het kontakt met de patient te werk moest blijven gaan, zoals hij dat tot nu toe gewend was. De gebruikelijke gang van zaken in deze reglo bij een aanvraag voor laboratoriumdiagnostiek is, dat de huisarts of via hem de doktersassistente op een aanvraagformulier van het Diagnostisch Centrum in het kort informatie noteert over de klacht van de patient, over de bevindingen bij het onderzoek, een voorlopige diagnose stelt en aankruist welk laboratoriumonderzoek wordt verlangd. Voor de gegevensverzameling voor dit onderzoek bleek dit formulier om de volgende redenen niet te voldoen:

Informatie over bijvoorbeeld de mate van besmettelijkheid van een infektieziekte, geschat door de huisarts; de voorlichting aan de patient; het maken van kontrole-afspraken met de patient door de behandelaar; eventuele verwijzingen, kortom zaken betreffende het behandelingsplan, worden niet op dit formulier vastgelegd.

Niettemin zijn deze gegevens bij een onderzoek naar de zorgverlening aan patienten met acute diarree van groot belang.

Daarbij kwam nog het volgende probleem met betrekking tot het Diagnostisch Centrum-aanvraag formulier.

Bij bestudering van oude ingevulde Diagnostisch Centrum-aanvraagformulieren werd het duidelijk dat deze in het algemeen summier worden ingevuld door de huisarts.

Deze argumenten waren voldoende aanleiding voor de onderzoeker om een apart formulier voor de gegevensverzameling van dit onderoek te ontwerpen.

In het proefonderzoek werden 2 typen formulie- 
ren getest. Het zogenaamde "gesloten" formulier bevatte voorgedrukte rubrieken ten aanzien van de anamnese, het onderzoek, de evaluatie en het plan. Direkt na het kontakt met de patient moest door de behandelaar worden aangekruist welke onderwerpen (onderdelen) aan de orde waren geweest.

op het andere type formulier, het zogenaamde "open" formulier kon de behandelaar in eigen bewoordingen eveneens direkt na het kontakt met de patient noteren welke anamnestische vragen $\mathrm{c} \cdot \mathrm{q}$. handelingen aan bod waren gekomen.

Uit de evaluatie van het proefonderzoek bleek dat het "gesloten" formulier onder meer om de volgende twee redenen niet voldeed.

Ten eerste werd het formulier door de huisarts tijdens en niet na het kontakt met de patient ingevuld.

Ten tweede werden vaak alle rubrieken die op het formulier stonden afgedrukt ter sprake gebracht en systematisch afgewerkt, ondanks de instruktie het formulier zo niet te gebruiken. Het gesloten formulier werkte te sturend. Er was een handelwijze ontstaan, die afwijkend was van de normale gang van zaken in het arts-patient kontakt.

Het "open" formulier voldeed beter, alhoewel ook niet ideal. Bij het gebruik van dit formulier werden huisartsen niet geholpen door een voorgedrukt geheugensteuntje.

Ook het tijdstip van noteren speelde ten aanzien van de uitgebreidheid van de verkregen informatie, bij deze wijze van registreren, nauwelijks een rol. Wel deed zich een oud bekend probleem voor.

Doordat het "open" formulier nogal een gelijkenis vertoonde met het oorspronkelijke Diagnostisch Centrum aanvraagformulier ontstond tijdens het proefonderzoek alras de gebruikelijke wijze van invullen van aanvraagformulieren door huisartsen, hetgeen betekende summiere informatie. Deze gelijkenis was echter voor dit type formulier opzettelijk nagestreefd om te voorkomen dat dit onderzoek te zeer zou interveniëren in de gebruikelijke gang van 
zaken in de huisartspraktijk met betrekking tot het aanvragen van laboratorium-diagnostiek.

Een slechte registratie en beperkte resultaten na een jaar verzamelen ten gevolge van overlast, zouden de opbrengst kunnen zijn. Vooral het feit dat de deelnemers van het proefonderzoek een periode van 12-13 maanden registreren, zoals voorzien was in het definitieve onderzoek, nogal bezwaarlijk achtten, woog zwaar. Iedere belasting moest tot een minimum beperkt blijven. Uit de analyse van het proefonderzoek kwam naar voren, dat het "open" formulier met enige redaktionele bijstellingen de voorkeur genoot. Er werd een kombinatie van beide formulieren gemaakt. Gegevens met betrekking tot de anamnese konden in eigen bewoordingen worden weergegeven. De rubrieken over lichamelijk onderzoek, de evaluatie en het plan vertoonden een gesloten karakter en de informatie werd door middel van aankruisen verkregen (zie bijlagen I en II).

Het probleem van het onvolledig invullen van de formulieren werd zo goed mogelijk opgevangen door een zorgvuldige lay-out en door het geven van een uitgebreide persoonlijke instruktie over het gebruik van het formulier. Daarnaast ontvingen alle deelnemers elke maand per brief informatie over het aantal en soort verwekkers dat tot dan toe in dit onderzoek was verzameld. Telkens werd men herinnerd aan het volledige invullen van het formulier. Tevens werden in het kader van de begeleiding van dit onderzoek de huisartspraktijken regelmatig bezocht. Hierbij werd niet alleen over de lopende zaken als bijvoorbeeld de bevoorrading van het verzendmateriaal gesproken, maar ook de zo gewenste volledigheid van het aanvraagformulier kwam ter sprake.

Dit aanvraag- annex gegevensverzamelingsformulier werd door alle deelnemers uit zowel de Aals de B-groep gebruikt wanneer een faecesmonster ter kweek aan het laboratorium in Ziekenhuis Maastricht werd aangeboden.

De formulieren werden direkt na het invullen 
met het monsterpotje aan de patient meegegeven, zodat achteraf aanvullen van de gegevens niet voorkwam.

Het aanvraagformulier van de doktersassistente (alleen in groep A) kende een kleine modifikatie ten opzichte van dat van de huisarts in die zin, dat er geen onderzoeksgegevens op konden worden vastgelegd (zie bijlage II).

Elke praktijk ontving bij de start van het onderzoek een gelijk aantal monsterpotjes. De bevoorrading van de praktijken met steeds weer eenzelfde aantal geschiedde op aanvraag. Tijdens de regelmatige bezoeken van de onderzoeker aan de praktijk werden de voorraden telkens gekontroleerd. Het is niet voorgekomen, dat een praktijk over geen verzendmateriaal beschikte. Wel bleek uit de tellingen van de tevoren uitgereikte potjes minus het aantal ontvangen monsters op het laboratorium, dat in vrijwel alle praktijken zich patienten bevonden die aanvankelijk hun medewerking wel toezegden, maar uiteindelijk toch geen monsters inleverden.

Alle monsters verkregen van patienten uit groep A werden volgens een vaste afspraak (standaard) gekweekt op de volgende bakteriële mikro-organismen:

Salmonella/Shigella/Campylobacter fetus ssp jejuni/Yersinia enterocolitica

Vervolgens werd een detectie gedaan naar de volgende virologische organismen:

Rotavirus/Enterovirus/Adenovirus/Poliovirus 1-3/Coxsackievirus $\mathrm{A} 1-\mathrm{A} 27 /$ Coxsackie $\mathrm{B} 1-\mathrm{B} 7 /-$ Echovirus 1-37/Reovirus 1-3/Hepatitis A-virus/Calicivirus/Parvovirus/Norwalkvirus/Picornavirus.

Tenslotte werden de monsters van alle kinderen tot 10 jaar tevens onderzocht op:

wormeieren en kysten.

De huisartsen van groep $B$ konden op een aangehechte strook aangeven naar welke micro-organismen zij onderzoek wensten. Zij hadden 
daarbij dezelfde mogelijkheden als bij het oorspronkelijke Diagnostisch Centrum aanvraagformulier.

Alle praktijken werden door het secretariaat van het Diagnostisch Centrum op de voor alle uitslagen geldende wijze geinformeerd met dien verstande, dat de uitslag van de virologie doorgaans 14-21 dagen later beschikbaar was, vanwege onder meer de beperkte kapaciteit van de afdeling Electronen-microscopie.

\subsection{Follow-up onderzoek (bijlage III, IV,V,- VI).).}

In de vorige paragraaf is melding gemaakt van de zorg die er bestond ten aanzien van het verzamelen van de gegevens.

De verwachting was dat ondanks alle begeleidende inspanningen van de onderzoeker er toch een onvoldoende resultaat zou worden verkregen, als men zich zou beperken tot het aanvraagformulier. Om verzekerd te zijn van een voldoende aantal valide gegevens werd een follow-up onderzoek onder de patienten met acute diarree opgezet. Met dit onderzoek werden de volgende doelen beoogd:

Ten eerste zouden gegevens via dit onderzoek verkregen, een waardevolle aanvulling uit de eerste hand kunnen zijn op die van de huisarts.

Ten tweede zou er informatie verkregen kunnen worden over het beloop van de klacht. Deze gegevens ontbraken tot nu toe bij studies over de klacht acute diarree.

Ten derde ontstond de mogelijkheid om, alhoewel niet formeel behorend tot de uitwerking van de vraagstellingen, na te gaan welke hinder de patient van deze klacht ondervond in de zin van staken van de dagelijkse bezigheden.

Het onderzoek werd als volgt opgezet:

8 à 10 dagen na het kontakt van de patient met de praktijk werden zoveel mogelijk patienten telefonisch geënquêteerd (zie bijlage III). 
Deze enquête omvatte een aantal kategorieën vragen:

Kategorie A betrof vragen over de voornaamste aspekten van de klacht van de patient in de periode voorafgaande aan het kontakt met de praktijk. In wezen werd er een standaard anamnese afgenomen zoals de onderzoeker deze uit de literatuur, uit de enquête onder 34 huisartsen (zie hoofdstuk 2.2) en uit eigen ervaring bekend was.

Kategorie B behelsde voornamelijk vragen over de farmacotherapie

Kategorie $C$ bevatte vragen over het moment na het kontakt met de praktijk waarop de patient vaststelde dat hij minder klachten had

Kategorie $D$ Hierin kwamen vragen aan de orde of en hoe de klacht zich manifesteerde op het moment van het telefonisch kontakt. In feite werden dezelfde anamnestische aspekten als in kategorie A nagevraagd

Kategorie $\mathbf{E}$ In deze kategorie werden hoofdzakelijk vragen gesteld over het plan $\mathrm{C.q}$. het beleid van de huisarts

Tenslotte werd door middel van dit enquete-onderzoek informatie verkregen over het voorkomen van diarree in het gezin van de patient ten tijde van diens klachten. Er werd uitgegaan van een periode lopend van één week voor het debuut van de klacht van de patient tot aan het moment dat de enquête werd afgenomen, hetgeen neerkwam op een tijdsspanne van ongeveer 2-3 weken.

Over dit telefonisch verricht follow-up onderzoek kan nog worden vermeld, dat volgens opgaaf van de PTT de telefoondichtheid van de onderzoeksregio geen verschil toonde met de andere distrikten van de provincie. Er kon ruim 80zvan de patienten via de telefoon worden bereikt. 
Het is niet warschijnlijk dat de groep patienten die geen telefoon bezat of niet kon worden bereikt, een andersoortige diarreeklacht doormakkten dan diegenen die wel per telefoon konden worden bereikt. Formeel kan van een zekere selektie gesproken worden maar gezien de onderzoeksopzet, waarbij er voor het follow-up onderzoek een beperking tot de telefonische bereikbaarheid bestond, kon niet anders gehandeld worden.

In dit onderzoek werd bij het afnemen van de telefonische enquete zoveel mogelijk getracht de patient zelf aan het woord te laten. Het is evenwel in de dagelijkse praktijk gangbaar, dat indien een kind om wie het meestal gaat, geen informatie kan of wil geven, de ouders c.q. verzorgers dit voor hem zullen doen en de huisarts dan evenzeer met de op deze wijze verkregen gegevens zijn beleid moet bepalen. Tegen deze achtergrond is het van minder importantie, dat een aantal gegevens niet rechtstreeks van de betrokkene zijn verkregen.

3.6. Precisering van de vraagstellingen

3.6.1. Inleiding

In de vorige paragrafen is een beschrijving gegeven van de onderzoeksmethoden (aanvraaggegevensverzamelingsformulier en follow-upformulier) ten behoeve van de beantwoording van de vraagstellingen 1 en 2 en de vragen met betrekking tot de hinder voor de patient en de werklast voor de huisarts. De resultaten, gebaseerd op de gegevens verkregen van patienten en huisartsen uit groep $A$, worden beschreven in hoofdstuk 4 .

Voor de beantwoording van vraagstelling 1 en 2 (zie inleiding) is een precisering noodzakelijk. Immers in de eerste vraagstelling wordt onder meer gesproken van de presentatie, het beloop, het voorkomen van diarree in het gezin van de patient, de ard van de arts-patientkontakten, maar daarmee is aan deze begrippen nog geen inhoud gegeven. 
Hetzelfde kan gezegd worden ten aanzien van de tweede vraagstelling, die betrekking heeft op het handelen van de huisarts bij deze klacht. Bij de presentatie van de klacht gaat het in dit onderzoek om het voorkomen van een aantal onderdelen van de anamnese, waarvan wordt aangenomen dat deze doorgaans in het eerste arts-patient-kontakt aan de orde komen. Het betreft de zogenaamde premedische fase, waarmee een periode wordt bedoeld, die aanvangt bij het debuut van de klacht tot het kontakt van de patient (of diens verzorger) met de huisartspraktijk. Over de volgende onderdelen werden gegevens verzameld: duur, frekwentie, konsistentie, kleur, bloed, slijm, braken, buikpijn, koorts, hoofdpijn en het ziektegevoel.

De vragen met betrekking tot het beloop van de klacht, zij het beperkt tot 8 à 10 dagen na het kontakt van de patient met de praktijk, hadden voornamelijk betrekking op de duur van diverse hiervoor genoemde onderdelen van de anamnese.

Vervolgens werd met het "voorkomen van diarree in het gezin" aangeduid de uitbreiding van de klacht in het gezin van de patient ten tijde van diens ziekteperiode. Met dit gegeven zou inzicht verkregen kunnen worden in de totale omvang van het voorkomen van de klacht in een bepaalde populatie. Tevens werd nagegaan welke hinder de patient van de klacht ondervond in de zin van het onderbreken van de dagelijkse bezigheden (werk, school, huishouden).

De vraagstelling over de verleende zorg door de huisarts werd uitgewerkt in vragen over ernst, de besmettelijkheid van de klacht, de therapie en het beleid.

Tenslotte werd een vraag gesteld met betrekking tot de werklast voor de huisarts, waarbij het ging om het a antal en de aard van de kontakten met de huisartspraktijk. Twijfels aan de veronderstelling, dat acute diarree een simpele weinig belastende klacht zou zijn, lagen hieraan ten grondslag. 
3.6.2. Presentatie van de klacht.

Ten aanzien van de presentatie van de klacht werden de volgende vragen geformuleerd:

1. Hoelang hadden patienten diarree voordat zij naar de huisarts gingen?

2. Wat was de defaecatiefrekwentie van patienten met acute diarree?

3. Wat was de vorm van de ontlasting bij patienten met acute diarree?

4. Wat was de kleur van de ontlasting bij patienten met acute diarree?

5. Hoe vaak werd er bloed en/of slijm waargenomen bij patienten met acute diarree?

6 . Hoeveel patienten met acute diarree hadden last van braken?

7. Hoe vaak kwam er koorts voor bij patienten met acute diarree?

8. Hoeveel patienten voelden zich ziek bij de klacht acute diarree?

\subsubsection{Beloop}

Bij de uitwerking van het onderdeel -het beloop- van de klacht acute diarree stonden de volgende vragen centraal:

1. Wat was de duur van de klacht acute diarree na het kontakt van de patient met de huisartspraktijk?

2. Hoe lang waren de bijmengingen bloed en slijm in de ontlasting van patienten met acute diarree aanwezig?

3. Hoe lang was de totale duur van de klacht?

4. Hoe lang bestond het ziekte-gevoel bij patienten met acute diarree?

5. Hoe lang bestond er koorts bij patienten met acute diarree?

6. Hoeveel patienten hadden hun dagelijkse bezigheden (school, werk, huishouden etc.) gestaakt en hoe lang? 
3.6.4. Voorkomen van diarree in het gezin

Bij de gezinsbesmetting ging het in dit onderzoek om de vragen:

1. In hoeveel gezinnen kwam er behalve bij de patient in dezelfde periode ook bij andere leden diarree voor?

2. Kwamen er bij patienten met acute diarree in wier gezin ook anderen diarreeklachten hadden, meer positieve kweekuitslagen voor dan bij patienten, die de enige met diarree waren in het gezin?

3. Wat was de voornaamste bijkomende reden van appèl?

\subsubsection{Verleende zorg}

In dit onderzoek werden de volgende aspekten van de verleende zorg of $\mathrm{m} \cdot \mathrm{a} . \mathrm{w}$. van het handelen van de huisarts onderscheiden: het lichamelijk onderzoek, het laboratoriumonderzoek, de ernst en de besmettelijkheid van de klacht en het plan, uitgewerkt in dieetvoorschrift, farmacotherapie en voorlichting, c.q. uitleg over de klacht aan de patient.

Deze aspekten gaven aanleiding tot de volgende vragen:

1. Bij hoeveel patienten met acute diarree verrichtte de huisarts een lichamelijk onderzoek?

2. Bij hoeveel patienten verrichtte de huisarts zelfstandig of via een streeklaboratorium een laboratorium-onderzoek anders dan een faeceskweek?

3. Wat was de betekenis van de begrippen ernst en besmettelijkheid van de klacht acute diarree voor de diagnostiek?

4. Aan hoeveel patienten met acute diarree werd een dieetadvies gegeven?

5. Aan hoeveel patienten met acute diarree werd farmacotherapie voorgeschreven?

6. Aan hoeveel patienten werd voorlichting, c.q. uitleg over de klacht gegeven door de huisarts en waaruit bestond die?

7. Hoe vaak werd er voor de klacht acute 
diarree in een ziekteperiode een beroep gedaan op de huisartspraktijk en wat was de vorm van de kontakten?

Tot zover de operationalisering van de vraagstellingen 1 en 2 . De beantwoording van de derde vraagstelling met betrekking tot het voorkomen van microbielle agentia bij acute diarree werd ter hand genomen door van patienten van de huisartspraktijken van groep $A$ een standaardonderzoeksprocedure van de faeces uit te voeren en bij de patienten van groep $B$ alleen volgens aanvraag van de huisarts een onderzoek te doen. De gevolgde laboratoriumbepalingen staan beschreven in paragraaf 3.7 en het resultaat in hoofdstuk 5 .

De vierde vraagstelling met betrekking tot de analyse naar de bijdrage van de onderscheiden anamnestische gegevens zoals eerder bij de presentatie van de klacht aangeduid aan een te verwachten kweekuitslag, wordt behandeld in hoofdstuk 6. De vraag naar een voorspellende waarde van de anamnese met betrekking tot het voorkomen van een microbiëel organisme kan in feite gesteld worden voor alle onderdelen van de anamnese. Toch staan bloed, slijm, koorts en van oudsher de kleur bijzonder in de belangstelling en zullen zonder meer in de analyse worden betrokken.

Tenslotte is het volgende met betrekking tot de operationalisering van de vraagstellingen van belang te vermelden. Het ontbreken van een infrastruktuur in huisartspraktijken voor het doen van onderzoek heeft de onderzoeker ertoe genoopt vrijwel alle faciliteiten zelf te ontwikkelen. Er heeft een kontinue zorg bestaan om voldoende valide gegevens te kunnen verzamelen. Ondanks alle inspanningen ten aanzien van het verzamelen van de gegevens is uit het registratie-aanvraagformulier geen beeld te schetsen van de presentatie van de klacht, c.q. het handelen van de huisarts met betrekking tot de anamnese. Aangenomen werd, 
dat de "anamnese" uit het follow-up onderzoek model zou kunnen staan voor een doorsnee afgenomen voorgeschiedenis door de huisarts bij de klacht acute diarree. Voor de beantwoording van de vraagstellingen werd voornamelijk gebruik gemaakt van de gegevens verkregen via het follow-up onderzoek.

van het registratie-aanvraagformulier zijn de gegevens over het verrichte onderzoek door de huisarts, de besmettelijkheid, de ernst van de klacht, de therapie en vanzelfsprekend de kweekuitslag bij de analyse betrokken.

\subsection{Laboratori umbepalingen}

Alle faecesmonsters werden bakteriologisch, parasitologisch (bij kinderen $t / m$ lo jaar) en virologisch onderzocht. Het bakteriologisch onderzoek betreft het onderzoek op aanwezigheid van Salmonella spp, Shigella spp, Campylobacter spp, en Yersinia enterocolitica.

Van de faecesmonsters werd een suspensie gemaakt in $5 \mathrm{ml}$. steriel water, $\mathrm{pH}=7$. Deze suspensie werd vervolgens direkt en na ophoping in een aankweekmedium geënt op verschillende selektieve voedingsbodems.

Voor onderzoek op Salmonella spp. en Shigella spp op een Salmonella/Shigella-plaat (=SS plaat), een Desoxycholaat-citraat (=DC9) plaat, een Brilliant-groen plaat en Hektoën agarplaat, voor onderzoek op Campylobacter spp, een selektieve Campylobacter plat en voor Yersinia enterocolitica een DC, een SS en een Endoplaat. Na incubatif gedurende respektievelijk $1 \times 24$ uur bij $37^{\circ} \mathrm{C}$ en $2 \times 24$ uur bij $42^{\circ} \mathrm{C}$ en $4 \times 24$ uur bij $22^{\circ} \mathrm{C}$ werden de verdachte kolonies afgeënt en serologisch en biochemisch geïdentificeerd. Van alle eerste isolaten werd een gevoeligheidsbepaling uitgevoerd. Voor onderzoek op Campylobacter is het microscopisch beeld in de fase-contrastmicroscoop. s-vormige gebogen staafjes met 1-4 windingen, die door het gezichtsveld heen schieten, een belangrijk hulpmiddel. Het parasitologisch onderzoek op wormeieren en 
kysten omvatte de microscopische beoordeling van preparaten, die direct van de faeces dan wel na concentratie van de faecesmonsters met behulp van een verzadigde $\mathrm{NaCl}$ oplossing gemaakt worden. De preparaten werden gekleurd met eosine ( 2 gram eosine per $100 \mathrm{ml}$ ), met Jodium ( 2 gram Jodium., 3 gram Kaliumjodide per $100 \mathrm{ml}$ aqua dest) en met een $100 \mathrm{x}$ en $400 \mathrm{x}$ vergroting beoordeeld.

Het virologisch onderzoek betrof het onderzoek op Rotavirus met behulp van een indirekte ELISA methode. Voor Entero, Adeno, Polio type 1,2 en 3, Coxsackie A1-A27, Coxsackie Bl-B7, Echo 1-37, Hepatitis A, Calici, Parvo, Norwalk en Picorna-virussen werd de weefselkweek gebruikt. Hiertoe werd de faeces gesuspenseerd in $2 \mathrm{ml}$. Nutrientbroth waraan toegevoegd penicilline, streptomycine en fungizone, vervolgens gecentrifugeerd en het supernatant $(0,05 \mathrm{ml})$ geënt op 1 buis diploïde foetale cellen en $\mathbb{1}$ buis tertiaire apeniercellen. De buizen werden $2 x$ per week gekontroleerd op een cytopatisch effekt gedurende 2 weken.

De indirekte ELISA methode (8) voor het aantonen van het Rotavirus werd als volgt uitgevoerd.

De cupjes van een microtiterplaatje werden gecoat get geit-anti Rotavirus serum en 3 uur bij $37 \mathrm{C}$ geincubeerd. Vervolgens werd het overtollige serum verwijderd, de cupjes c.q. de plaatjes gewassen en nagecoat met $2 \%$ bovine serum albumine in fosfaatbuffer gedurende 10 minuten bij $37 \mathrm{C}$. Het niet gecoate albumine werd verwijderd en de cupjes gewassen. Het supernatant ( $100 \mathrm{uL}$ ) van de testen faecessuspensies $(0.2 \mathrm{~g} / \mathrm{ml})$ verkregen na centrifugatie gedurende 5 minuten bij 3000 rpm werd agn leder cupje toegevoegd en 1 uur bij $37 \mathrm{C}$ geincubeerd. Vervolgens werden de plaatjes weer gewassen en geincubeerd met peroxidase gelabeld anti Rota immunglobuline (=conjungaat) gedurende 1 uur bij $37 \mathrm{C}$. Na het wassen werd het substraat toegevoegd: $4 \mathrm{mg}$. orthophenyl diamine per ml fosfaatbuffer met $0,05 \%$ $\mathrm{H}_{2} \mathrm{O}_{2}$ en 15 minuten in het donker bij kamertemperatuur geincubeerd. De reaktie werd gestopt 
door toevoegen van $50 u 1$ UN $\mathrm{H}_{2} \mathrm{SO}_{4}$ aan ieder cupje en de extinctie van iedel cufpje afgelezen met behulp van een spectrofotometer ( $\mathrm{T}$ itertek, Multiscan) bij een golflengte van 492 $\mathrm{nm}$. De verkregen waarden werden gerelateerd aan de extinctie van een bekend antigeen. Een exctinctie van 0.400 werd als positief beschouwd.

Tenslotte werd telkens van elk $5 \mathrm{e}$ monster een elektronen microscopie (EM) verricht ter kontrole van de indirekte ELISA-methode. Bovendien werd van iedere positieve Rotavirus-uitslag een elektronen microscopische bevestiging verricht. 
HOOFDSTUK 4 : RESULTATEN

4.1. Presentatie van de klacht.

Inleiding

Voor de beantwoording van de vragen over de presentatie van de klacht stond het volgende onderzoeksmateriaal ter beschikking. Huisartsen en doktersassistenten in groep $A$ leverden via het aanvraagformulier (zie hoofdstuk 3.4) gegevens over 589 patienten met acute diarree.

Van deze 589 patienten konden 481 patienten via een telefonische enquête 8 à 10 dagen na het kontakt van de patient met de huisartspraktijk worden ondervraagd $(81,78)$. De rest had geen telefoon of kon, ondanks herhaalde pogingen, niet worden bereikt. Tabel 4.1.1 toont van deze twee groepen patienten een leeftijdsverdeling in vier kategorieën: zuigelingen, kinderen, volwassenen en bejaarden.

TABEL 4.1 .1

Leeftijdsverdeling van het totaal antal patienten met diarree in de groep A ten opzichte van het aantal telefonisch geënqueteerde patienten.

leeftijd

totaal aantal patienten telefonisch geënqueteerde patienten $z$
1-12 maanden

$1 \mathrm{t} / \mathrm{m} 10$ jaar

$11 t / m 70$ jaar

ouder dan 71 jaar $29 \quad 4,9$

589
245,0

$133 \quad 27,6$

$301 \quad 62,6$

$23 \quad 4,8$

Uit tabel 4.1 .1 is af te lezen, dat de groep 
van 481 wat de leeftijd betreft dezelfde verdeling vertoont als de totale groep van 589, zodat in dit opzicht geen sprake is van enige vertekening.

In hoofdstuk 3.5 werd vermeld, dat in de telefonische enquête door de onderzoeker in feite een standaardanamnese werd afgenomen. Dit werd onder meer gedaan, omdat het vermoeden bestond, dat het door de huisarts bij het monster ingevulde aanvraagformulier wel eens te weinig informatie zou kunnen bevatten om als gegevensverzamelingsformulier dienst te doen. Dit bleek inderdaad. Voor de onderzoeker was dit een reden om voor de beantwoording van de vragen, voortvloeiend uit de eerste vraagstelling, te putten uit het materiaal van de telefonische enquête. Vanzelfsprekend kon geen rechtstreeks antwoord verkregen worden van zuigelingen en jonge kinderen. In dergelijke gevallen werd gesproken met ouders of verzorgers. Ook gaven niet alle patienten op alle vragen een bruikbaar antwoord. Tevens was niet elk onderdeel van de anamnese van meet af aan in de enquête opgenomen.

Vooral de laatste twee beperkingen geven een verklaring van het wisselend aantal respondenten per onderdeel.

Premedische fase

Duur

Aan patienten met acute diarree, die kontakt opnamen met de huisartspraktijk werd de vraag gesteld: Hoe lang had $u$ al diarree voordat $u$ naar de dokter ging? Het antwoord werd gerubriceerd in drie groepen: $1 \mathrm{t} / \mathrm{m} 3$ dagen, $4 \mathrm{t} / \mathrm{m}$ 7 dagen en meer dan 7 dagen.

Vervolgens werd er nagegaan of er verschil bestond in duur van de klacht (aantal dagen diarree in de premedische fase) bij patienten van verschillende leeftijden.

Daartoe werd de totale groep patienten als volgt in 7 leeftijdskategorieën verdeeld: 
0-12 maanden (1); $1 \mathrm{t} / \mathrm{m} 4$ jaar (2); $5 \mathrm{t} / \mathrm{m} 10$ jaar (3); $11 \mathrm{t} / \mathrm{m} 30$ jaar (4). $31 \mathrm{t} / \mathrm{m} 50$ jaar (5); $51 \mathrm{t} / \mathrm{m} 70$ jaar $(6) ; 71$ jaar en ouder $(7)$. In de leeftijdskategorieën $1 \quad(n=24) ; 2 \quad(n=106)$ en $3 \quad(n=27)$ werd eenzelfde verdeling gevonden tussen patienten, die 1-3 dagen diarree hadden en de groep die het 4-7 dagen hadden. De verdeling jongens en meisjes in deze leeftijdskategorieën vertoonde eveneens een konstante verhouding van resp. 40 en $60 \%$.

Tabel 4.1.2 toont de resultaten voor de leeftijdskategorieën $1,2,3$, waarbij het dus uitsluitend personen betreft die voor deze klacht de hulp van de huisarts inriepen.

TABEL 4.1 .2

Aantal dagen diarree in de premedische fase in de leeftijaskategoriën 1,2 en 3 in percentages $(\mathrm{N}=157)$

aanta 1

totaal

dagen

0-12 mnd $1 \mathrm{t} / \mathrm{m} 4 \mathrm{j}$ (1)

(2)

$\mathrm{n}=24 \quad \mathrm{n}=106$

$5 \mathrm{t} / \mathrm{m} 10 \mathrm{j}$ kinderen (3)

$\mathrm{n}=27$

$\mathrm{N}=157$

$1-3: 41,7$

38,7

44,4

40,1

$4-7$

41,7

36,8

40,7

38,2

$>7 \quad 16,6$

24,5

14,9

21,7

Uit tabel 4.1 .2 is af te lezen, dat er vrijwel net zoveel kinderen of beter gezegd hun ouders of verzorgers tussen 1-3 dagen na het ontstaan van de klacht kontakt opnemen met de huisartspraktijk als tussen 4-7 dagen.

Dit gegeven gevoegd bij de konstante verhouding in de geslachtsverdeling, zijn aanleiding geweest om voor dit onderdeel "Duur" deze 3 groepen tot één zogenaamde kindergroep samen te voegen. zuigelingen vormen kennelijk in dit opzicht geen bijzondere groep.

De leeftijdskategoriën $4,5,6$ en 7 geven 
weliswaar een andere verdeling tussen patienten met 1-3 dagen acute diarree en de groep met 4-7 dagen dan bij de kinderen, mar op zich is ook hier sprake van een konstante verhouding (zie tabel 4.1 .3 ).

TABEL $4 \cdot 1 \cdot 3$

Aantal dagen diarree in de premedische fase in de leeftijdskategorieën $4,5,6$ en 7 in percentages

$(\mathrm{N}=308)$

$\begin{array}{llllll} & (4) & (5) & (6) & (7) & \text { totaal } \\ \text { aantal } & 11 & 31 & 51 & 71 & \text { volwassenen } \\ \text { dagen } & \mathrm{t} / \mathrm{m} & \mathrm{t} / \mathrm{m} & \mathrm{t} / \mathrm{m} & + \\ & 30 & 50 & 70 & \text { ouder } \\ & \mathrm{n}=117 & \mathrm{n}=101 & \mathrm{n}=67 & \mathrm{n}=23 & \mathrm{~N}=308 \\ 1-3 & 56,4 & 58,4 & 65,7 & 52,2 & 58,8 \\ 4-7 & 32,4 & 27,7 & 23,9 & 17,4 & 27,9 \\ 7 & 11,2 & 13,9 & 10,4 & 30,4 & 13,3\end{array}$

Zoals lit tabel 4.1 .3 is af te lezen kan evenals bij de andere leeftijdskategorieën voor de duur van de klacht in de pre-medische fase gesproken worden van één groep. Bejaarden nemen ten aanzien van de duur van de klacht geen aparte positie in binnen deze groep, alhoewel er hier meer patienten zijn die lang wachten dan in de andere leeftijdsgroepen. Het geringe aantal bejaarden bemoeilijkt de interpretatie van dit cijfer.

De leeftijdskategoriën $4,5,6$ en 7 kunnen samengevoegd worden tot een zogenaamde volwassenengroep, temeer daar de geslachtsverdeling in deze kategoriën een konstante verhouding vertoont tussen mannen en vrouwen van resp. 45 en $55 \%$.

Defaecatiefrekwentie

Tabel 4.1 .4 toont de resultaten van de antwoorden op de vraag: Hoe vaak ging $u$ per dag 
naar het toilet voor de ontlasting? De vraag werd aangepast aan de leeftijd, in die zin, dat het bij zuigelingen en jonge kinderen ging om het aantal vuile luiers en broeken.

De verdeling van de defaecatiefrekwenties tussen de 7 leeftijdskategoriën vertoonde evenals bij het onderdeel "Duur" een konstante verhouding. Wederom werden de patienten voor dit onderdeel samengevoegd in twee groepen kinderen en volwassenen.

TABEL 4.1 .4

Defaecatiefrekwentie per dag in de premedische fase bij kinderen en volwassenen in percentages

$$
(\mathrm{N}=471)
$$

\begin{tabular}{|c|c|c|c|}
\hline $\begin{array}{l}\text { aantal keren } \\
\text { per dag }\end{array}$ & $\begin{array}{l}\text { kinderen } \\
\mathrm{n}=157\end{array}$ & $\begin{array}{l}\text { volwassenen } \\
n=314\end{array}$ & $\begin{array}{l}\text { totaal } \\
N=471\end{array}$ \\
\hline $3-5$ & 61,8 & 43,2 & 49,3 \\
\hline-10 & 19,1 & 29,0 & 25,8 \\
\hline$>\quad 10$ & 19,1 & 27,8 & 24,9 \\
\hline
\end{tabular}

Uit de cijfers kan worden afgelezen dat er in dit onderzoek meer volwassenen met een hoge defaecatiefrekwentie bij de klacht acute diarree zijn dan kinderen. Het zou kunnen zijn, dat bij kinderen eerder, dat wil zeggen bij een lagere frekwentie, reeds de hulp van de arts wordt ingeroepen dan bij de volwassenen. Van de 19,18 van de kinderen met een frekwentie van meer dan 10 maal per dag bevond zich $70 \%$ in de leeftijaskategorie 2 (1 t/m 4 jaar).

De 27,88 van de volwassenen met een dergelijke frekwentie zijn gelijk verdeeld over de leeftijdskategoriëen $4,5,6$ en 7 .

Indien de hoge defaecatiefrekwentie als een belangrijke faktor voor de ernst van de klacht over met name het vochtverlies zou mogen worden gerekend, dan zou vooral bij kinderen tussen de 1 en 5 jaar voor dit aspekt extra 
aandacht geboden zijn.

Konsistentie

Tabel 4.1 .5 geeft de resultaten weer van de antwoorden van de twee groepen patienten op de vraag: Hoe was de vorm van de ontlasting in die periode? ook voor dit onderdeel gaven alle zeven leeftijdskategorieën vrijwel dezelfde verdeling te zien tussen patienten met een waterdunne en patienten met een brijige of pappige ontlasting.

TABEL 4.1 .5

Konsistentie van de ontlasting in de premedische fase bij kinderen en volwassenen in percentages.

$(\mathrm{N}=480)$

kinderen volwassenen totaal
$\mathbf{n}=156$
$\mathrm{n}=324$
$N=480$

waterdun

73,7

82,7

79,8

pappig/brijig 25,6

16,3

19,4

andere bena-

mingen

0,7

1,0

0,8

Tabel 4.1.5 toont, dat van de patienten die zich bij de huisarts melden, meer volwassenen waterdunne diarree hebben dan kinderen, terwijl deze laatste groep weer vaker pappige diarree presenteert. Niettemin is de waterdunne diarree verreweg (bijna 80\%) de meest voorkomende konsistentie bij de patienten in dit onderzoek.

In de enquête kwam onder meer de vraag voor: Na hoeveel dagen ging de klacht over?

Uit de beantwoording bleek, dat de patienten deze vraag verschillend interpreteerden. De ene patient gaf de duur van de klacht aan als de grootheid die daarvoor bepalend is, voor een ander was het de defaecatiefrekwentie en 
nog weer anderen noemden de konsistentieverandering.

Duur, frekwentie en konsistentie vormen bij de presentatie door de patient als het ware de kern van de diarree.

Het formeren van twee groepen, kinderen en volwassenen, in dit onderzoek is voornamelijk gebaseerd op het gegeven, dat voor de 3 kernonderdelen van de klacht een konstante verdeling van het voorkomen van deze onderdelen over de diverse leeftijdskategorieën ( $1 \mathrm{t} / \mathrm{m} 7$ ) werd wargenomen.

Voor de bespreking van de resultaten van de andere anamnese-onderdelen bij deze klacht zal de groepsindeling in kinderen en volwassenen worden aangehouden .

Op grond van bepaalde aspekten is het logisch te veronderstellen dat er bij zuigelingen toch sprake is van een aparte groep. Immers de voeding wijkt sterk af van die van de andere oudere kinderen. De verteringsprocessen in de darm moeten nog rijpen. Defaecatiepatronen zijn gemakkelijker te beinvloeden. Dit zijn argumenten om in dit onderzoek de zuigelingen als een zelfstandige groep binnen de kindergroep te vermelden. Het wordt dan mogelijk te beoordelen of de bijzondere situatie van deze patientjes een anderssoortige presentatie van de klacht met zich meebrengt dan bij de oudere kinderen het geval is.

Kleur

Tabel 4.1 .6 toont de resultaten van de antwoorden op de vraag: welke kleur had de ontlasting in de periode voordat u naar de dokter ging? 
TABEL 4.1 .6 .

Kleur van de ontlasting in de pre-medische fase bij zuigelingen, kinderen en volwassenen in percentages

$(\mathrm{N}=474)$

zuigelingen kinderen volwassenen
$\mathrm{n}=23$
$\mathrm{n}=152 \quad \mathrm{n}=299$

$\begin{array}{llll}\text { bruin } & 13,0 & 26,3 & 54,2 \\ \text { geel } & 52,2 & 48,7 & 25,1 \\ \text { groen } & 34,8 & 17,8 & 11,0 \\ \text { zwart - } & 1,3 & 7,0 \\ \text { stopverf - } & 5,9 & 2,0 \\ \text { andere be- } & & \\ \text { namingen - } & - & 0,7\end{array}$

Bij de volwassenen heeft iets meer dan de helft van de patienten een bruine kleur van de ontlasting bij acute diarree. Bij de kinderen wordt geel door iets minder dan de helft van de patienten wargenomen, bij de zuigelingen lets meer dan de helft.

De groene kleur is sterker vertegenwoordigd in de kindergroep dan in de volwassenengroep, maar niet zo uitgesproken als de gele kleur. Een op de drie zuigelingen met diarree in dit onderzoek had een groene ontlasting. Het percentage geel zou nog hoger kunnen uitvallen indien hierbij het percentage van de stopverfkleur werd opgeteld. Beide kleuren zijn immers sterk verwant en een specifikatie van de kleuren werd door de interviewer niet aan de patient gevraagd.

De gele kleur zou in dat geval bij $55,1 \%$ van de kinderen voorkomen en bij $27,1 \%$ van de volwassenen. 
Bloed/sijjm

Vragen naar bijmengingen als bloed en slijm zouden moeten behoren tot het vaste anamnesepatroon van de huisarts in het kontakt met patienten met acute diarree.

De verdeling over drie leeftijdsgroepen is af te lezen in tabel 4.1 .7 en 4.1 .8 .

TABEL 4.1 .7

Bloed bij de ontlasting in de pre-medische fase bij zuigelingen, kinderen en volwassenen in percentages. $(\mathrm{N}=471)$

zuigelingen kinderen volwassenen
$n=24$
$\mathrm{n}=133$
$\mathrm{n}=314$

wel bloed $12,5 \quad 15,0 \quad 13,4$

geen bloed 87,5

85,0

86,6

Voor dit kenmerk blijkt er bij zuigelingen, kinderen en volwassenen geen verschil in voorkomen te bestaan.

TABEL 4.1 .8

slijm in de ontlasting in de pre-medische fase bij zuigelingen, kinderen en volwassenen in percentages.

$(N=451)$

zuigelingen kinderen volwassenen

$n=24 \quad n=128 \quad n=299$

$\begin{array}{llll}\text { wel slijm } & 66,7 & 49,2 & 40,8\end{array}$

geen slijm $33,3 \quad 50,8 \quad 59,2$

Slijm bij de diarree-ontlasting komt meer voor bij zuigelingen en kinderen dan bij volwassenen.

Bloed en slijm worden in de anamnese vaak in een adem genoemd door de huisarts en waar- 
schijnlijk wordt hiermee geëxploreerd naar het voorkomen van een microbiële verwekker.

In hoofdstuk 6 over het indikatieschema zal aan dit punt verder aandacht worden geschonken.

Nast de bijmengingen kent de anamnese een aantal vragen over zogenaamde bijbehorende klachten.

Met bijbehorende klachten worden door de huisarts veelal aspekten als braken, koorts, buikpijn, ziektegevoel en het bestaan van bijzonderheden c.q. komplikaties bedoeld. Hierna volgt een beschrijving van het voorkomen van deze kenmerken van de anamnese bij de patienten met acute diarree in dit onderzoek.

\section{Braken}

Vochtverlies i.c. uitaroging is een verschijnsel dat voor de patient grote risiko's met zich meebrengt.

Diarree en braken zijn in dit opzicht twee elkaar versterkende kenmerken. Hieruit volgt dat het al of niet braken van een patient een waardevol gegeven is voor een te volgen beleidslijn door de behandelaar. Uit de beantwoording van de vraag: Had u (of de baby c.q. het kind) ook last van braken? werd al spoedig duidelijk dat het voor de patient bij een positief antwoord bijzonder moeilijk is om hoeveelheden aan te geven.

Braken werd in dit onderzoek door de patient aangeduid met: soms, veel, weinig, een beetje, af en toe, e.d. De indruk bestaat dat braken voor de patient een onderdeel is van het meer of minder ziek zijn c.q. voelen; het risiko van uitaroging komt daar in tweede instantie nog eens bovenop.

Het antwoord van de patient op deze in de huisartspraktijk gebruikelijke vraag bij deze klacht verschaft de behandelaar in feite geen inzicht of, afgaand op dit kenmerk de kans op uitdroging reëel aanwezig is. Bij het verzamelen van gegevens over dit kenmerk is met de frekwentie c.q. het aantal c.c. braaksel geen 
rekening gehouden, daar er vrijwel nimmer in de huisartspraktijk een dergelijke precisie in de vraagstelling wordt toegepast en omdat de ervaring leert dat patienten op dit soort vragen in algemene termen antwoord geven.

TABEL 4.1 .9

Braken in de pre-medische fase bij zuigelingen, kinderen en volwassenen in percentages. $(N=479)$

$\begin{array}{lll}\text { zuigelingen } & \begin{array}{l}\text { kinderen } \\ \mathrm{n}=23\end{array} & \begin{array}{l}\text { volw } \\ \mathrm{n}=\end{array} \\ 26,0 & 48,5 & 30,2 \\ 74,0 & 51,5 & 69,8\end{array}$

Bijna de helft van de kinderen van $1 \mathrm{t} / \mathrm{m} 10$ jaar, waarvoor de hulp van de huisarts werd ingeroepen, hadden in geval van acute diarree in dit onderzoek tevens last van braken en hun risiko's ten aanzien van het uitdrogingsgevaar is wat deze kombinatie betreft (diarree + braken) groter dan bij de volwassenen. Zuigelingen bleken daarentegen juist minder klachten van braken dan hun wat oudere mede-patienten.

Niettemin komt braken bij zuigelingen veel voor en is als faktor voor het uitdrogingsgevaar niet te verwaarlozen.

Wanneer er voor de grote groep volwassenen wordt teruggekeerd naar de oorspronkelijke indeling in leeftijdskategorieën $4,5,6$ en 7 , dan blijkt dit kennmerk geen voorkeur te bezitten voor één van deze kategorieën.

Buikpijn

Buikpijn lijkt een zeer voor de hand liggend kenmerk in kombinatie met diarree. Bij de onderzoeker bestond de indruk dat buikpijn door patienten niet alleen als onprettig wordt ervaren maar nog al eens als zorgwekkend. Wellicht is buikpijn in een aantal gevallen de 
primaire reden van het appel. In de verwerking van de gegevens werd de aanduiding pijn en kramp tot één begrip buikpijn verengd. Buikpijn werd door de patienten vaak aangegeven als intermitterend en mar zelden als een konstant aanwezig probleem. Tabel 4.1 .10 toont de resultaten van dit onderdeel. Vanwege de subjektiviteit van de beoordeling van buikpijn bij zuigelingen, zijn voor deze groep hierover geen gegevens in de tabel opgenomen.

\section{TABEL $4.1 \cdot 10$}

Buikpijn in de pre-medische fase bij kinderen en volwassenen in percentages.

$(\mathrm{N}=468)$

kinderen

$\mathrm{n}=143$

63,6

36,4 volwassenen

$\mathrm{n}=325$

85,8

wel buikpijn

14,2

Het feit, dat er minder kinderen klachten hadden over buikpijn dan volwassenen zou zijn oorsprong kunnen vinden in het feit, dat met name zeer kleine kinderen niet anders dan via de warneming van de ouders $c \cdot q$. verzorgers informatie kunnen verschaffen omtrent dit kenmerk.

In dit opzicht is het opvallend, dat naarmate het verbale vermogen van de kinderen toeneemt ook het aantal kinderen met buikpijn bij de klacht acute diarree toeneemt. Deze percentages voor de leeftijdskategorieën 2 en 3 zijn resp. $63,58 \quad(n=96)$, en $85,18 \quad(n=27)$.

\section{Koorts}

In de anamnese van de klacht acute diarree wordt de vraag naar het bestaan van koorts meestal routinematig gesteld. Veelal is de vraag bedoeld om informatie te krijgen over de ernst van de klacht.

Patienten met koorts worden als zieker be- 
schouwd dan patienten zonder koorts. Een tweede reden van het vragen naar koorts kan liggen in het vermoeden dat patienten met koorts wellicht vaker een microbiële verwekker als oorzaak van hun klacht hebben dan de groep patienten, die geen koorts heeft.

De vragen in dit onderzoek over het bestaan van koorts behelsden niet alleen de koorts op zich, maar ook het zich koortsig voelen. Uit de beantwoording bleek dat voor de patient het hebben van koorts en het zich koortsig voelen, identieke begrippen zijn (zie tabel 4.1 .11 ).

TABEL 4.1 .11

Koorts of koortsig gevoel in de pre-medische fase bij zuigelingen, kinderen en volwassenen in percentages, volgens mededeling van de patient of diens verzorger. $(\mathrm{N}=473)$

$$
\begin{array}{lll}
\text { zuigelingen } & \text { kinderen } & \text { volwassenen } \\
\mathrm{n}=24 & \mathrm{n}=133 & \mathrm{n}=316
\end{array}
$$

$\begin{array}{llll}\text { wel koorts } & 41,7 & 48,1 & 47,8 \\ \text { geen koorts } & 58,3 & 51,9 & 52,2\end{array}$

Er is vrijwel geen verschil in het voorkomen van koorts of een koortsig gevoel bij zuigelingen, kinderen en volwassenen bij de klacht acute diarree. Wederom zou bij dit kenmerk van de anamnese kunnen worden aangetekend, dat zulgelingen en kinderen niet in staat zullen zijn aan te geven of zij zich koortsig voelen. Het antwoord voor deze groepen zal voornamelijk een weerslag zijn van de perceptie van de ouders of verzorgers. Voor de beoordeling van dit kenmerk makkt het voor de huisarts evenwel geen verschil uit, daar hij voor een belangrijk deel afhankelijk is van wat de patient of diens verzorgers hem vertellen. Zeker ten aanzien van klacht acute diarree zal de huisarts zich meestal niet overtuigen of een koortsig gevoel ook daadwerkelijk een verho- 
ging van de lichaamstemperatuur betekent. Evenmin zal de huisarts wanneer er sprake is van koorts of koortsig gevoel volgens de patient, toch routinematig de temperatuur meten.

In dit onderzoek werd aan alle patienten die aangaven koorts of een koortsig gevoel te hebben, gevraagd, hoe hoog de temperatuur was, indien gemeten. Een groot aantal patienten gaf ongevraagd de hoogte van de temperatuur op ongeacht of er sprake was van koorts of een koortsig gevoel. Uit de beantwoording van de patient werd duidelijk dat hij meestal de hoogst bereikte waarde opgeeft als de gemeten temperatuur. Over de uiteindelijke duur van de temperatuur kon geen bruikbaar cijfer worden verzameld. De temperatuur werd bij het bestaan van een koortsig gevoel vaak herhaaldelijk gemeten zolang men zich ziek voelde.

Niet de hoogte van de temperatuur bepaalde het moment van stoppen met temperatuur opnemen, maar het zich al dan niet ziek voelen.

Bij de verzameling van de gegevens over dit kenmerk werd ervan uitgegaan dat er sprake vap koorts was bij temperaturen hoger dan $37,5 \mathrm{c}^{8}$ (zie tabel 4.1.12).

TABEL 4.1 .12

Gemeten temperatuur in de pre-medische fase in percentages bij zuigelingen, kinderen en volwassenen

$(\mathrm{N}=368)$

zuigelingen

$\mathrm{n}=20$ kinderen volwassenen $\mathrm{n}=104 \quad \mathrm{n}=244$

$\operatorname{meer} \mathrm{dagn}$

45

38,5

34,4

minder

dan $37,5 \mathrm{c}^{\circ} \quad 55 \quad 61,5 \quad 65,6$

Naar aanleiding van de gegevens van tabel 
4.1.12. blijkt de vraag in de anamnese naar het bestaan van koorts niet erg zinvol. Immers vele patienten geven aan, koorts te hebben of zich koortsig te voelen, terwijl er toch geen koorts bestond.

Waarschijnlijk bestaat er een verschil in opvatting tussen huisartsen en patienten wat wel of wat niet als koorts, in de zin van graden Celcius, kan worden aangemerkt.

De vraag naar koorts in de anamnese, zonder het vaststellen van de hoogte van de temperatuur, heeft weinig waarde.

Hoofdpijn

Oorspronkelijk was er geen vraag over hoofdpijn in de enquête opgenomen. Er werd aangenomen dat patienten met acute diarree zich over het algemeen wel niet erg lekker zouden voelen en dat hoofdpijn een onderdeel zou kunnen uitmaken van de zogenaamde algemene malaiseverschijnselen en niet een op zich zelf staand kenmerk.

In de beantwoording van de vraag of patienten zich van deze klacht ziek voelden, werd nogal eens spontaan melding gemaakt van het bestaan van "erge" hoofdpijn. De hoofdpijn was zo heftig, dat deze volgens de patient niet beschouwd mocht worden als de "normale" hoofdpijn, die iedereen wel eens heeft, vooral als men zich niet lekker voelt.

De gegevens over het kenmerk hoofdpijn in dit onderzoek hebben betrekking op deze door de patient bedoelde "erge" hoofdpijn (zie tabel $4.1 .13)$. 
TABEL $4.1 \cdot 13$

Hoofdpijn in de premedische fase in percentages bij kinderen en volwassenen. $(\mathrm{N}=377)$

kinderen

$\mathrm{n}=98$
. volwassenen

$\mathrm{n}=279$

wel "erge" hoofdpijn

10,2

37,3

geen "erge"

hoofdpijn

89,8

62,7

Ten aanzien van de kindergroep duikt de vraag op in hoeverre de verschafte gegevens betrouwbaar zijn.

Immers ouders c.q. verzorgers geven antwoord voor het kind zolang dit niet in stat is betrouwbare informatie te verschaffen.

Het onderscheid tussen gewone hoofdpijn en "erge" (anders dan gewone) hoofdpijn kan in deze leeftijdsgroep aanleiding zijn tot onnauwkeurigheden, vooral in de groep van de jonge kinderen.

In de groep 5-10 jarigen $(n=21)$ werd een percentage van 28,58 erge hoofdpijnklachten opgegeven, hetgeen tendeert naar het percentage van de volwassenen.

\section{ziek voelen}

In dit onderzoek werd ook geinformeerd of patienten zich werkelijk ziek voelden. Het zich ziek voelen wordt in het medisch jargon vaak samengevat onder de noemer algemene malaise. Hieronder worden begrippen gevangen als: moe, futloos, gammel, overal pijn, beroerd voelen, niet lekker voelen, grieperig etc. Beantwoordingen van de patient in deze zin werden in dit onderzoek als positief, d.w.z. als ziek voelen aangeduid.(zie tabel 4.1.14) Het belang van deze vraag ligt in de veronderstelling dat in de huisartspraktijk 
het ziek voelen van een patient kan leiden tot akties, met name symptomatische therapieën, die niet in direkt verband met de mogelijke oorzaak van de klacht staan.

TABEL 4.1 .14

Ziek voelen in de pre-medische fase in percentages bij zuigelingen, kinderen en volwassenen $(\mathrm{N}=414)$

kinderen

$\mathrm{n}=124$ volwassenen

$\mathrm{n}=290$

wel ziek

68,5

68,9

niet ziek

31,5

31,1

Bij de kinderen en volwassenen is dezelfde verdeling terug te vinden in patienten die zich wel en niet ziek voelen.

Nabeschouwing .

Patienten, die met de huisartspraktijk kontakt opnemen vanwege de klacht acute diarree presenteren de klacht met het vermelden van een aantal kenmerken. Voor de ene patient is dit het aantal dagen dat er diarree bestaat, de duur dus, voor een ander gaat het om het aantal malen dat het toilet wordt bezocht, de defaecatiefrekwentie, en weer anderen bedoelen de konsistentie van de ontlasting, wanneer zij aangeven diarree te hebben.

Het bleek dat er in ait onderzoek procentueel evenveel kinderen waren met $1-3$ dagen acute diarree voordat kontakt werd opgenomen met de huisartspraktijk als met 4-7 dagen. Dit verschijnsel wordt bepaald door het gedrag van ouders c.q. verzorgers en er is warschijnlijk geen sprake van twee verschillende groepen patienten.

Bij de volwassenengroep in dit onderzoek, die de hulp van de huisarts inroepen, is het percentage patienten dat na $1-3$ dagen klachten 
de praktijk opzoekt beduidend hoger (698) dan de groep die 4-7 dagen wacht (288).

Toch zou men verwachten, dat in de kindergroep het gevaar voor uitdroging vooral wanneer er een kombinatie bestaat met braken, voor de ouders $c . q$. verzorgers een belangrijke faktor vormt voor het bepalen van het moment van kontakt met de huisartspraktijk.

Ten aanzien van de defaecatiefrekwentie is te konstateren, dat in de volwassenengroep zich meer patienten melden met een hoge frekwentie dan in de kinderengroep.

Een verklaring voor dit verschijnsel zou kunnen zijn, dat bij het kind reeds bij een aantal malen dunne ontlasting de hulp van de huisarts wordt ingeroepen, terwijl volwassenen zich pas bij een fiks hoge frekwentie melden met diarree.

Andere kenmerken van de klacht acute diarree als bijmengingen van bloed en/of slijm of bijbehorende klachten als koorts, braken, buikpijn, zijn waarschijnlijk voor de patient veel meer bijkomstigheden, die de uitgebreidheid of de ernst van de klacht c.q. de ziekte bepalen. 
4.2. Beloop van de klacht

Inleiding.

Wanneer aan patienten gevraagd wordt hoelang de diarree heeft geduurd, wordt dat veelal afgemeten aan de daling van de frekwentie of aan de verbetering van de konsistentie.

om te kunnen bepalen hoelang de diarree na het kontakt van de patient met de huisartspraktijk nog heeft bestaan, werd uitgegaan van deze twee kenmerken. De cijfers in deze paragraaf over dit onderzoek hebben alleen betrekking op het tijdstip van de defaecatievermindering, die overigens hier nauwkeurig overeenkomen met de uitkomsten van de konsistentieverbetering.

De onderzoeksopzet stond helaas niet toe de interessante vraag of de farmacotherapeutische interventie van de huisarts van invloed is geweest op de duur van de klacht, verder te exploreren.

Allereerst zullen in deze paragraaf de gegevens over de totale duur van de klacht besproken worden. Daarnaast komen ook de duur van de bijmengingen en bijbehorende klachten aan de orde.

Voorafgaand aan de bespreking van de resultaten zijn er nog twee belangrijke zaken te melden:

1. De gegevens, die hier worden gepresenteerd, hebben alleen betrekking op de patienten, die de hulp van de huisarts inriepen. Dit onderzoek heeft zich tot deze groep beperkt.

Patienten die met deze klacht de huisarts bezoeken, kunnen dat doen vanwege de klacht zelf, maar ook vanwege het beloop van de klacht. In die zin is er sprake van een bijzondere groep. Ten aanzien van de interpretatie van de resultaten m.b.t. het beloop van de klacht acute diarree dient hiermee rekening gehouden te worden.

2. Het vervolgen van de klacht heeft zich 
beperkt tot een termijn van 8 à 10 dagen. Om reden van organisatorische aard kon de groep patienten, die na deze termijn nog klachten had, niet verder worden gevolgd. Dit betekende dat het cijfermateriaal met betrekking tot de totale duur van de klacht of onderdelen ervan geen interpretatie toeliet voor die gevallen warin de patient op het moment van de afname van de enquête meedeelde dat hij nog of weer klachten had.

De hier gepresenteerde cijfers met betrekking tot de onderdelen totale duur van de klacht en de duur van de aanwezigheid van bloed, slijm, braken en buikpijn hebben dan ook betrekking op de patienten die ten tijde van de afname van de enquête geen klachten meer hadden.

Beloop.

Bij de bespreking van het beloop van een klacht is het van belang de totale duur van deze klacht te kennen.

In het telefonisch follow-up onderzoek (zie bijlage III) werd onder meer nagegaan, hoeveel dagen de patient diarree had voordat hij of zij kontakt opnam met de huisartspraktijk en hoelang de diarree daarna nog aanwezig was. Tabel 4.2.1 geeft de resultaten weer van het totaal aantal dagen diarree, uitgedrukt in percentages, voor twee leeftijdsgroepen, warbij in acht genomen moet worden, hetgeen in de inleiding t.a.v. de interpretatie is opgemerkt. 
TABEL $4.2 \cdot 1$

Het totaal aantal dagen diarree in procenten, voor de leeftijdsgroepen kinderen en volwassenen.

$(\mathrm{N}=465)$

totaal aantal

dagen diarree

42 dagen

3-4 dagen

5-7 dagen

$\geqslant 8$ dagen

\section{kinderen $n=157$}

$\begin{array}{rr}2,6 & 7,8 \\ 8,3 & 21,7 \\ 35,7 & 35,1 \\ 53,4 & 35,4\end{array}$

volwassenen

$\mathrm{n}=308$

8

21,7

35,4

Opvallend is de lange duur van de klacht zowel bij de kinderen als bij de volwassenen. voor ruim de helft van de kinderen $(53,4 \%)$ en meer dan eenderde van de volwassenen $(35,4 \%)$ betekent acute diarree 8 dagen of langer in meer of mindere mate diarree.

Deze percentages zetten de algemeen aanvaarde mening onder artsen dat (acute) diarree doorgaans een klacht van zeer beperkte duur is, op losse schroeven.

In dit kader is het wellicht interessant de resultaten te vermelden van de duur van de diarree na het kontakt van de patient of diens verzorger met de huisartspraktijk. De vraag over dit onderdeel in de telefonische enquete werd gespecificeerd door expliciet te vragen naar de defaecatiefrekwentie (en de konsistentie).

In tabel 4.2 .2 is het resultaat wat de defaecatiefrekwentie betreft voor de leeftijdsgroepen kinderen en volwassenen weergegeven. 
TABEL 4.2 .2

Het aantal dagen diarree sinds het kontakt met de praktijk voor de leeftijdsgroepen kinderen en volwassenen, gemeten aan de frekwentie, uitgedrukt in percentages van de betreffende groep.

$(\mathrm{N}=475)$

$\begin{array}{lll}\text { aantal } & \text { kinderen } & \text { volwassene } \\ \text { dagen } & n=156 & n=319 \\ \text { diarree } & 37,8 & 48 \\ & 28,2 & 30 \\ 52 \text { dagen } & 25 & 15,4 \\ 3-4 \text { dagen } & 9 & 6,6 \\ 5-7 \text { dagen } & 8 \text { dagen* } & \end{array}$

* de groep patienten die aangaven dat hun klacht niet over was, maar juist verslechterd, bevindt zich in de rubriek > 8 dagen.

Uit de tabel is af te lezen dat bijna 358 van de kinderen na het kontakt met de huisartspraktijk nog altijd 5 of meer dagen diarree hadden. Van de volwassenen had bijna de helft na het kontakt met de praktijk nog twee dagen diarree. Bijna driekwart van de patienten was na 4 dagen van de diarree verlost.

Vervolgens werd bij patienten die bloed of slijm bij de ontlasting hadden waargenomen, nagegaan hoeveel dagen deze bijmengingen in het totaal aanwezig waren.

Tabel 4.2.3 geeft het resultaat weer met betrekking tot het onderdeel bloedbijmenging, waarbij vanwege het beperkte aantal patienten met bloed bij de ontlasting, de verdeling naar de leeftijdsgroepen achterwege is gebleven. 
TABEL 4.2 .3

Het percentage patienten met bloed bij de ontlasting, verdeeld naar het totaal aantal dagen dat bloed bij de ontlasting werd wargenomen. (N totaal $=471)(\mathrm{N}$ pos $=63$ )

aantal dagen bloed 8 patienten

bij de ontlasting
$\leqslant 2$ dagen
55,5
3-4 dagen
14,3
5-8 dagen
14,3
nog bloed
bij de ontlasting* 15,9

* nog bloed in de ontlasting betekent dat deze patienten tijdens de telefonische enquete opgaven bloed bij de ontlasting waar te nemen ongeacht het tijdstip van de aanvang.

Uit tabel 4.2 .3 is af te lezen dat bijna $70 \%$ van de patienten met bloed bij de ontlasting er in total niet langer dan 4 dagen last van had.

Tabel 4.2 .4 geeft de resultaten weer m.b.t. het onderdeel slijm t.a.v. de totale duur, uitgesplitst naar twee leeftijdsgroepen. 
TABEL 4.2 .4

Percentage patienten, uitgesplitst naar twee leeftijdsgroepen met slijm in de ontlasting. verdeeld naar het aantal dagen dat slijm in de ontlasting werd waargenomen. ( $N$ totaal $=451)(\mathrm{N}$ pos $=172)$

aantal dagen

slijm

kinderen

volwassenen

in de ontlasting

$\mathrm{n}=75$ $\mathrm{n}=97$

* 2 dagen

40

38,2

3-4 dagen

26,7

22,7

5-8 dagen

21,3

17,5

nog slijm in

de ontlasting

12

21,6

* nog slijm in de ontlasting betekent, dat deze patienten tijdens de telefonische enquete opgaven slijm bij de ontlasting waar te nemen ongeacht het tijdstip van de aanvang.

Ruim $60 \%$ van zowel de kinderen als de volwassenen hebben niet langer dan 4 dagen slijm bij de ontlasting.

Belangrijk meer volwassenen dan kinderen in dit onderzoek hadden langdurig slijm bij de ontlasting.

Vervolgens ging de aandacht uit naar het beloop van het onderdeel braken. Braken betekent immers vochtverlies en daardoor tevens een grotere kans op dehydratieverschijnselen bij patienten met acute diarree. Aan patienten die op een verzoek daartoe opgaven te braken, werd gevraagd hoeveel dagen deze klacht aanwezig was geweest (zie ook opmerkingen over dit onderdeel en in hoofdstuk 4.1). Tabel 4.2 .5 toont de resultaten van dit onderzoek. 
TABEL 4.2 .5

Percentage patienten, uitgesplitst in twee leeftijdsgroepen, die gebraakt hadden, verdeeld naar het aantal dagen dat braken werd opgegeven .

$(\mathrm{N}=166)$

aantal dagen braken

kinderen

$\mathrm{n}=68$

63,2

26,5

10,3 volwassenen $\mathrm{n}=98$

66,3

11,4

14,1

8,2

nog braken

- 8,2

* nog braken betekent dat deze patienten tijdens de telefonische enquête opgaven last te hebben van braken, ongeacht het tijdstip van de aanvang.

Bijna 90\% van de kinderen die bij de diarree ook last hadden van braken hadden daar in het totaal niet langer dan 4 dagen last van. Bij de volwassenen ligt dit percentage ruim $10 \%$ lager. Van de 8 volwassenen die langdurig klachten hadden van braken bevonden zich 6 personen in de leeftijdskategorie van 31-50 jarigen.

Het voorkomen van buikpijn bij diarree lijkt een voor de hand liggende kombinatie. Nagegaan werd wat de totale duur van de buikpijn was.

Tabel 4.2 .6 geeft de resultaten weer. 
TABEL $4.2 \cdot 6$

Percentage patienten, uitgesplitst naar twee leeftijdsgroepen met buikpijn, verdeeld naar het aantal dagen dat buikpijn werd waargenomen.

$(\mathrm{N}=337)$

$\begin{array}{lll}\begin{array}{ll}\text { aantal dagen } \\ \text { buikpijn }\end{array} & \begin{array}{l}\text { kinderen } \\ n=80\end{array} & \begin{array}{l}\text { volwa } \\ n=25\end{array} \\ & & \\ 3-4 \text { dagen } & 23,8 & 29,6 \\ 5-8 \text { dagen } & 27,2 & 22,9 \\ \text { nog buikpijn } & 36,5 & 32,3 \\ & 12,5 & 15,2\end{array}$

nog buikpijn betekent dat deze patienten tijdens de telefonische enquête opgaven buikpijn te hebben, ongeacht het tijastip van de aanvang.

Bij iets meer dan de helft van de patienten met buikpijn duurt deze klacht niet langer dan 4 dagen.

Het zich ziek voelen is waarschijnlijk een belangrijk argument voor de patient om kontakt op te nemen met de huisarts. Uitgaande van de antwoorden, verkregen via de telefonische enquete gaf $68 \%$ van de patienten in het eerste kontakt met de huisartspraktijk op zich ziek te voelen, terwijl $32 \%$ meedeelde dat zulks niet het geval was.

De verdeling van de patienten, die zich ziek voelden en zij die opgaven daarvan geen last te hebben, over de twee leeftijdsgroepen vertoonde dezelfde verhouding.

Een niet onbelangrijk deel van de patienten in dit onderzoek, bijna $70 \%$, zei zich ziek te voelen van een op het eerste gezicht simpele klacht. In de telefonische enquete, afgenomen 8 à 10 dagen na het eerste kontakt van de patient met de huisartspraktijk, werd nagegaan of men zich op dat moment nog ziek voelde. op de vraag over dit onderdeel gaf $88,3 \%$ van 
de patienten aan zich weer goed te voelen, terwijl 11,7 zich nog immer ziek voelde.

In tabel 4.2.7 zijn deze uitkomsten uitgesplitst naar twee leeftijdsgroepen.

TABEL 4.2 .7

Percentage patienten met acute diarree, dat zich ziek voelde 8 à 10 dagen na het eerste kontakt met de huisartspraktijk, verdeeld naar twee leeftijdsgroepen.

$(\mathrm{N}=426)$

$\begin{array}{lll} & \\ n=137 & n=289 & n=426\end{array}$

niet ziek

89,8

87,5

88,3

wel ziek

10,2

12,5

11,7

De cijfers in tabel 4.2 .7 geven echter geen informatie over hoe ziek de patienten met acute diarree zich voelden.

Om hierover gegevens te kunnen verzamelen, werd bij 303 personen uit het totale bestand verder onderzoek gedaan. Hierbij werd van het volgende uitgegaan:

- personen zijn "echt" ziek, waanneer zij niet in staat zijn hun dagelijkse bezigheden te verrichten

- de dagelijkse bezigheden worden gedifferentieerd in de volgende categorieên: school; betaald werk; huishouden; uitkeringsgerechtigden volgens de AOW en WW en onbekend.

- de gegevens zullen alleen uit de groep volwassenen gegeven worden.

In de telefonische enquete werd gevraagd of men ondanks de diarree de dagelijkse bezigheden was blijven verrichten. De interesse ging hierbij uit naar de totale duur van de inaktieve periode.

Tabel 4.2 .8 toont de resultaten voor mannen en vrouwen. 
TABEL 4.2 .8

Percentage patienten van 11 jaar en ouder uitgesplitst naar geslacht, gedifferentieerd naar de ziekteduur in dagen

$(\mathrm{N}=303)$

$\begin{array}{lll}\text { aantal dagen } & \text { mannen } & \text { vrouwen } \\ \text { ziekteverzuim } & \mathrm{n}=146 & 57 \\ \leqslant 2 \text { dagen } & 45,2 & 50,3 \\ 3-4 \text { dagen } & 16,5 & 13,4 \\ 5-6 \text { dagen } & 8,2 & 8,9 \\ 27 \text { dagen } & 30,1 & 27,4\end{array}$

chi kwadraat $=1,10$

Uit de berekening van de chi-kwadraat blijkt dat de ziekteduur tussen mannen en vrouwen geen signifikant verschil vertoont.

Verwacht werd dat vrouwen en met name de huisvrouwen een werkbelasting kenden, die geen lange periode van ziekteduur zou toelaten. Dit was aanleiding on de ziekteduur van huisvrouwen zonder betaald werk in verband te brengen met de groep mannen en vrouwen met wel betaald werk.

Tabel 4.2 .9 toont de resultaten. 
TABEL $4.2 \cdot 9$

Percentage patienten, uitgesplitst naar geslacht en wel of geen betaald werk, gedifferentieerd naar de ziekteduur in dagen. $(\mathrm{N}=195)$

\begin{tabular}{lll} 
ziektever- & \multicolumn{2}{l}{ huisvrouwen } \\
zuim in & $n=64$ & $\begin{array}{l}\text { mannen en } \\
\text { vrouwen met } \\
\text { betaald werk } \\
n=131\end{array}$ \\
$\leqslant 2$ dagen & 59,4 & 42 \\
$3-4$ dagen & 12,5 & 22,9 \\
$5-6$ dagen & 4,7 & 8,4 \\
7 dagen & 23,4 & 26,7
\end{tabular}

chi kwadrat $=6,09$

$0,5>p>0,1$

Uit tabel 4.2 .9 is af te lezen dat bij huisvrouwen in dit onderzoek met de klacht acute diarree het aantal dagen ziekteduur geen aanwijzing geeft voor een signifikant verschil t.o.v. hun lotgenoten, die aan het arbeidsproces deelnamen. In het algemeen kan gesteld worden, dat in dit onderzoek de dagelijkse bezigheden niet als bepalende faktor geduid kan worden voor het aantal dagen ziekteverzuim bij patienten die voor de klacht acute diarree de huisarts raadplegen. In de bespreking van de gegevens werden schoolgaande personen en uitkeringsgerechtigden buiten beschouwing gelaten.

Een kenmerk dat vaak de rol van graadmeter van de ernst van een aandoening heeft, is koorts. Een veel gebruikte uitdrukking van huisartsen in het kontakt met de patient is dan ook: "Als de temperatuur weer normaal is, mag $u$ weer uw gang gaan (of in geval van kinderen:) ..laten gaan". Afgaande op een dergelijk advies als 
richtsnoer voor het hervatten van de dagelijkse bezigheden van de patient, zou 97,28 na 8 à 10 dagen weer in de running zijn.

De vraag in de telefonische enquete werd als volgt gesteld: Heeft $u$ op dit moment nog koorts of voelt u zich koortsig?

Tabel 4.2 .10 toont de resultaten.

TABEL $4.2 \cdot 10$

Percentage patienten volgens eigen opgave met koorts of koortsig gevoel resp. geen koorts of koorstig gevoel 8 à 10 dagen na het kontakt met de huisartspraktijk, verdeeld naar twee leeftijdsgroepen

$(\mathrm{N}=472)$

koortsig

gevoel

geen koorts

wel koorts kinderen

$\mathrm{n}=153$

96,7

3,3 volwassenen

$n=319$

97,5

2,5

Uit tabel 4.2 .10 is af te lezen, dat koorts of koortsig gevoel na 8 à 10 dagen na het kontakt van de patient met de huisartspraktijk vrijwel niet meer voorkomt.

Dit geldt ook voor de bijmengingen bloed en slijm.

Bloed komt bij $97,8 \%$ op het bedoelde tijdstip niet voor en slijm bij de ontlasting is bij 93,38 van de patienten afwezig. De percentages vertoonden een konstante verdeling over de twee leeftijdsgroepen.

Samenvattend is in dit hoofdstuk een poging gedaan, zij het beperkt tot een termijn van 8 à 10 dagen, erachter te komen of de veronderstelling dat als patienten zich niet meer melden, de klacht wel verdwenen zal zijn of van geringe problematiek, op waarheid berust. 
Ten aanzien van de duur van de klacht na het eerste kontakt van de patient met de huisartspraktijk kan worden gesteld, dat kinderen langer klachten hadden dan volwassenen. Wanneer de totale duur van de klacht in de beschouwing wordt betrokken, kan eveneens gekonstateerd worden dat kinderen langer diarreeklachten bleken te hebben dan volwassenen. ondanks de geaccepteerde slogan, dat acute diarree een zichzelf limiterende ziekte is, bleek in dit onderzoek dat nog altijd 258 van de kinderen en ruim $15 \%$ van de volwassenen 5-8 dagen na het kontakt met de huisartspraktijk diarree of althans voor de patient geen normale ontlasting hebben. Deze percentages waren na 8 tot 10 dagen afgenomen tot respektievelijk 9 en $6,6 \%$. Ook bij de totale duur van de diarreeklacht bleek, dat kinderen langer diarreeklachten hadden dan volwassenen. De bijmengingen bloed en slijm komen na 8 à 10 dagen na het kontakt met de huisartspraktijk vrijwel niet meer voor. Wellicht zijn juist de patienten warbij de bijmengingen langer blijven bestaan een interessante groep voor nader onderzoek. Hetzelfde geldt voor het kenmerk koorts. Opmerkelijk is, dat bijna $70 \%$ van de patienten in dit onderzoek zich van een op het eerste gezicht eenvoudige klacht ziek voelden bij de eerste presentatie. Na 8 à 10 dagen gaf bijna $90 \%$ aan zich weer (redelijk) goed te voelen. 
4.3. Opname

Inleiding .

Tijdens de registratieperiode van dit onderzoek (zie hoofdstuk 3) zijn in totaal 4 patienten met acute diarree op verzoek van de huisarts opgenomen in een ziekenhuis. In deze paragraaf wordt een korte beschrijving gegeven van deze 4 ziektegeschiedenissen. De gegevens over het beloop van de klacht bij deze patienten zijn verkregen door middel van de telefonische enquête en via de patientendokumentatie van de vier betrokken huisartsen.

\section{PATIENT A}

Patient A was een scholiere van 18 jaar, die sinds een dag klachten had van buikpijn, waterdunne diarree en erg braken, waarbij ze zelfs geen druppel vocht kon binnen houden. Bij de ontlasting, die overigens een normale bruine kleur had, zou geen bloed of slijm gezien zijn. Patiente voelde zich behoorlijk ziek. Op dat moment had niemand anders in het gezin diarree. Patiente had geen idee wat de oorzaak van de klacht kon zijn.

Bij onderzoek waren er geen duidelijke afwijkingen te konstateren. Wel vond de huisarts dat patiente een zieke indruk makte.

Als vermoedelijke diagnose werd door de huisarts een bakteriële oorzaak opgegeven.

De behandeling bestond uit licht verteerbare kost, als medicatie: Motilium, zonodig een Baralgin en uitleg over de mogelijke besmettelijkheid van de klacht.

Aanvankelijk leek er een korte verbetering op te treden maar al spoedig kwamen de klachten in alle hevigheid terug. Dit leidde vanwege het gevaar van uitdroging tot een opname.

$\mathrm{Bij}$ het algemeen lichamelijk onderzoek werden 
geen afwijking gevonden.

Het laboratorium-onderzoek van de urine vertoonde geen afwijkingen. Het bloedbeeld was normaal, evenals de lever- en nierfunkties en het elektrolytengehalte. Serologie onderzoek op met name Yersinia was negatief. Faeceskweek op salmonella was eveneens negatief. Patiente kreeg parenterale vochttoediening, waarop zij goed reageerde. Daags na de opname ging patiente weer geleidelijk aan eten en na 5 dagen kon zij ontslagen worden.

Patiente had het beeld vertoond van een heftige gastro-enteritis. Er waren geen aanwijzingen voor een appendicitis.

In totaal is patiente inklusief 5 dagen opname 9 dagen ziek geweest. zij is i.v.m. deze klacht 4 mal op het spreekuur van de huisarts verschenen en eenmal op de polikliniek inwendige geneeskunde.

De uitslag van het faecesonderzoek bij deze patiente in het kader van dit onderzoeksprojekt luidde als volgt:

Salm/Shig: negatief. Campylobacter: negatief. Yersinia enterocolitica: positief (m.b.v. de koude ophopingstechniek).

Virologie: negatief (zie hoofdstuk 3 ).

De positieve Yersinia uitslag werd niet verder geëvalueerd.

PATIENTE B

Patient $B$ was een zuigeling van 5 weken die sinds 2 dagen een waterdunne diarree had met een frekwentie van 3-4 mal per dag. De ontlasting had een gele kleur, was slijmerig en er werd eenmaal bloed bij de faeces gekonstateerd.

Volgens de moeder was het kind behoorlijk ziek en zou het afvalien. Toch dronk het zijn flesje goed leeg.

In het gezin had een inwonende oma ook diar- 
ree, warbij uit de faeces een Salmonella groep B was gekweekt. Moeder van patient had eveneens lichte gastro-enteritis klachten.

De huisarts vond bij het algemeen lichamelijk onderzoek geen duidelijke afwijkingen. Het patientje had geen koorts en was niet uitgedroogd. Als vermoedelijke diagnose werd door de huisarts 'onbekend' opgegeven.

De behandeling bestond uit het geven van een dieetadvies, m.n. het verdunnen van de flesvoeding met rijstewater en uitleg over de mogelijke besmettelijkheid van de klacht.

Geleidelijk werd de klacht erger. Het kind bleef goed drinken, maar groeide slecht. Er was sprake van ondertemperatuur. Tien dagen na het debuut van de klacht liet de huisarts het kind opnemen.

Bij opname werd een magere zuigeling gezien, in een normale hydratietoestand. De lichaamstemperatuur was bij opname $36,8 \mathrm{C}$ en er werden geen duidelijke afwijkingen gevonden met name geen meningeale prikkelingsverschijnselen of afwijkingen of het gebied van de KNO.

Het laboratoriumonderzoek van de urine en bloed vertoonde geen afwijkingen. De Yersinia serologie was evenals de routine faeceskweek negatief.

Patientje kreeg verdunde Almiron $A B$ en kon na 6 dagen in goede algemene konditie worden ontslagen.

Er was sprake van een zuigeling met dyspepsie en een eenmalige bloederige diarree.

In het total is patientje inklusief de 6 dagen opname, 16 dagen ziek geweest. In deze periode is de moeder ariemal met het kind op het spreekuur van de huisarts geweest. De uitslag van het faecesonderzoek in het kader van dit projekt is als volgt: Salm/Shig. negatief; Campylobacter negatief; 
Yersinia negatief; wormeieren negatief; Lamblia kysten negatief; Virologie negatief (zie hoofdstuk 3).

\section{PATIENT C}

Patient $C$ was een vrouw van 37 jaar die klaagde over ernstige misselijkheid, hevig braken en een waterdunne diarree van wel meer dan 10 keer per dag. Patiente had geen bloed of slijm bij de ontlastigg wargenomen, wel had ze hoge koorts, tot $41 \mathrm{C}$. Patiente voelde zich erg ziek.

op dat moment waren er geen andere personen in haar gezin met diarreeklachten. Volgens patiente waren de klachten begonnen enkele uren na het eten van een broodje tartaar.

Bij onderzoek vond de huisarts geen afwijkingen. Als vermoedelijke diagnose werd door de huisarts een enteritis van een onbekende genese opgegeven.

Als behandeling kreeg patiente het advies veel te drinken en als medikatie Loperamide en Motilium. Patiente had zelf Norit en reform stopdruppels gebruikt.

Er trad in de daarop volgende dagen geen verbetering op. Patiente was inmiddels $7 \mathrm{kilo}$ afgevallen en de huisarts liet patiente onder de diagnose 'dehydratie' opnemen.

Bij de opname werd een licht uitgedroogde vrouw gezien, die een matig zieke indruk maakte. Bij het algemeen lichamelijk onderzoek werden geen afwijkingen gekonstateerd.

Het laboratoriumonderzoek van de urine vertoonde geen afwijkingen. In het bloed werd een verlaagd Kalium en Natriungehalte gekonstateerd. De faeceskweek bleek positief voor Salmonella groep B type typhimurium.

Patiente werd gerehydreerd, aanvankelijk enkele dagen intraveneus met $\mathrm{NaCl}$ en Glucose, 
waaraan KCL was toegevoegd. Na een week was patiente weer in goede algemene konditie en kon zij worden ontslagen.

Er was sprake van een patiente met een Salmonella infektie en dehydratieverschijnselen, waarbij een hyponatriaemie en hypokaliaemie bestond.

In het totaal is patiente 12 dagen ziek geweest, inklusief de opname. De huisarts heeft haar in deze periode, voor de opname, driemal aan huis bezocht.

De uitslag van het faecesonderzoek in het kader van dit onderzoeksprojekt luidde als volgt:

Faeceskweek: Salmonella positief groep $B$ typhimurium; Shigella negatief; Campylobacter negatief; Yersinia negatief.

Virologie: negatief. (zie hoofdstuk 3 )

PATIENT D

Patient $D$ was een bejaarde dame van 70 jaar, die sinds een dag last had van misselijkheid, braken en een waterdunne diarree van meer dan $10 \mathrm{x}$ per dag. Patiente had geen bloed of slijm bij de ontlasting gezien en zij had geen koorts. Ze voelde zich ziek.

Zij was weduwe en volgens haar zeggen waren ex geen personen in haar omgeving met diarreeklachten. Haar klachten waren enkele uren na het bijwonen van een carnavalsvergadering voor bejaarden acuut begonnen. Uit de voorgeschiedenis was bekend, dat patiente lijat een arteriitis temporalis, waarvoor zij behandeld werd met corticosteroïden.

De huisarts liet patiente de volgende dag opnemen onder de diagnose: forse diarree met gevaar voor dehydratie.

In afwachting van de opname gaf hij haar het 
advies veel te drinken en Loperamide caps. zelf had patiente ter bestrijding van de diarree Norit gebruikt.

Bij opname werd een matig zieke vrouw gezien, die aanspreekbaar was.

Het algemeen lichamelijk onderzoek leverde geen duidelijke afwijkingen op met uitzondering van een enigszins verlaagde huidturgor.

Het laboratoriumonderzoek van het bloed vertoonde een licht verhoogd ureum gehalte hetgeen wees op een lichte dehydratie. De faeceskweek bleek negatief.

Patiente werd behandeld met parenterale vochttoediening, waarbij de dosering glucocorticosteroiden tijdelijk werd verhoogd.

Na 10 dagen kon patiente in goede algemene konditie ontslagen worden met een iets verhoogde dosering prednisolon en een diabetes dieet.

Patiente bleef voorlopig onder kontrole van de specialist.

Konkluderend kon worden gezegd, dat het klachtenpatroon en het fysisch-diagnostisch onderzoek wezen op een heftige gastro-enteritis.

In totaal is patiente 10 dagen ziek geweest. De huisarts heeft in die periode eenmal een visite gemaakt.

De uitslag van het facesonderzoek in het kader van dit onderzoeksprojekt luidde als volgt:

Faeceskweek: Salm/Shig negatief, Campylobacter negatief, Yersinia negatief.

Virologie: negatief. (zie hoofdstuk 3 ). 
4.4. Voorkomen van diarree in het gezin van de patient.

Aan 323 patienten werd in de telefonische enquête een vraag gesteld over het bestaan van diarree in het gezin van de patient. Dit onderdeel werd drie maanden na de start van het onderzoek in het onderzoeksprotokol opgenomen. Een gezin werd in dit onderzoek gedefiniëerd als een leefvorm van minimal twee personen. De vraag luidde: "Waren er in deze periode - en rekent u maar vanaf een week voor $u$ begon met de diarree tot aan vandaag - nog andere personen in het gezin, die diarree hadden?"

De tijdsspanne bedoeld met deze periode, komt in konkreto neer op 2-3 weken.

Bij deze onderzoeksvraag waren een aantal zaken van belang.

Ten eerste: in die gevallen, warbij in dezelfde periode meer personen uit één gezin zich bij de huisartspraktijk meldden, werd dit gezin als zodanig maar éénmaal geregistreerd. Ten tweede: de periode van 2-3 weken, die bij deze onderzoeksvraag werd aangehouden, biedt op zich redelijk zekerheid op een goede registratie van de omvang van de diarreeklacht in het gezin. Niettemin is het mogelijk dat er in het gezin vlak na deze periode personen zijn geweest die diarree kregen.

In 35,68 van de gezinnen waarbij één van de gezinsleden de hulp van de huisarts inriep, waren er ook andere personen met diarree.

Tabel 4.4.1 geeft het percentage gezinnen aan, warin naast de diarreepatient ook bij andere gezinsleden diarree voorkwam, verdeeld naar de leeftijdsgroep en kinderen en volwassenen. 
TABEL 4.4 .1

Percentage gezinsleden met diarree, verdeeld naar twee leeftijdsgroepen: kinderen (tot 11 jaar) en volwassenen

$(\mathrm{N}=323)$

voorkomen diarree

Kinderen Volwassenen

$\mathrm{n}=111$

$n=212$

wel diarree gezin

48,6

28,8

geen diarree gezin

51,4

71,2

chi kwadraat $=12,55$ bij $p<0,0001$

Uit de cijfers blijkt, dat er signifikant meer gezinsleden diarree hebben wanneer de patient een kind is, dan wanneer het een volwassene betreft. In dit verband is het interessant te weten om hoeveel personen het gaat die behalve de patient ook diarree hebben, mar zich niet hebben gemeld bij de huisarts in relatie tot de komplete gezinssamenstelling. Met andere woorden: welk percentage diarree-patienten, die de huisarts niet raadplegen, zit verscholen achter het gezinslid dat wel de hulp inroept.

De 323 patienten waren afkomstig uit een totale populatie van 1051 personen. Naast deze 323 patienten, of anders gesteld: in de groep van 728 personen, bleken nog eens 127 personen diarree te hebben in dezelfde periode als de patienten en die dus geen hulp van de huisarts inriepen.

In dit onderzoek kon worden vastgesteld dat de sekundaire aanvalskracht van de klacht acute diarree 17,48 bedroeg:

$(1051-323=728: 127=17,48)$.

In dit verband is het wellicht interessant te melden, wat de werkelijke reden van de patient was om de hulp van de huisarts in te roepen. Aan 208 personen werd tijdens de enquête hierover een vraag gesteld. De reden dat niet 
aan de gehele groep patienten deze vraag gesteld werd, vindt zijn oorsprong in het feit, dat eerst 5 maanden na de start van het onderzoek deze vraag in de telefonische enquête is opgenomen.

De leeftijds- en geslachtsverdeling van deze groep patienten vertoonde met betrekking tot deze vraag dezelfde verhouding als bij de andere vragen in het onderzoeksprotokol.

Patienten geven uiteenlopende redenen van appèl op.

Uiteraard kwam de diarree op zich frekwent voor, maar er werd ook opgave gedaan van: overspannenheid, duizeligheid, het vermoeden van een nierkoliek, oorpijn, misselijkheid, koorts, hoofdpijn en buikpijn.

Soms gaven patienten meer redenen op. In dat geval werd hen uitdrukkelijk gevraagd aan te gaven welke de voornaamste reden was en deze werd dan genoteerd door de interviewer.

Toch zijn vragen naar de voornaamste reden van appèl vooral bij een klacht acute diarree niet zo eenvoudig te beantwoorden. Meestal is er sprake van een stelsel van oorzaken, waarbij op een bepaald moment er één de doorslag geeft met betrekking tot de beslissing hulp van de huisarts in te roepen. In de telefonische enquête is zorgvuldig nagegaan wat de werkelijke reden was. Niettemin zijn de antwoorden opgevat als voornaamste bijkomende reden, daar alie patienten één symptoom gemeenschappelijk hadden, namelijk diarree.

Tabel 4.4 .2 geeft een overzicht van de bijkomende redenen van appèl van patienten met acute diarree. 
TABEL 4.4 .2

Aantal patienten en de bijkomende redenen van appèl, verdeeld over twee leeftijdsgroepen $(\mathrm{N}=208)$

Kinderen $n=67$
Volwassenen $n=141$

Reden van appèl

buikpijn

bijmengingen

6

koorts

4

6

vermoeden van een

ernstige darmziekte

zich erg ziek voelen

andere reden

geen bijkomende reden alleen diarree

De antwoorden van patienten waren vaak te rubriceren als "het duurde te lang" en "de diarree zelf".

Beide rubrieken hebben betrekking op de klacht zelf en zijn voor de gegevensverwerking tot één kategorie -alleen diarreesamengevoegd.

Bij buikpijn ging het om de intensiteit van de pijn. De heftige pijn maakte deze patienten ongerust en deed hen de hulp van de huisarts inroepen. Kenmerken als koorts, maar vooral bloed en slijmbijmengingen bleken toch niet zulke verontrustende faktoren te zijn als werd verondersteld door de onderzoeker. Het zich ziek voelen bleek wel een drijfveer te zijn voor het inschakelen van de huisarts. Voor 18 volwassenen en 3 kinderen was dit de voornamste bijkomende reden om an de bel te 
trekken.

In het totaal gaf de groep van 208 patienten naast de diarree 22 verschillende redenen (rubrieken) aan waarom zij de huisarts hadden ingeschakeld. De rubriek "andere reden" in tabel 1 bevat 16 kategorieën. Uitgaande van deze getallen is het opvallend, dat in ongeveer $60 \%$ nog een andere reden in belangrijke mate bijdroeg aan de beslissing om met de huisartspraktijk kontakt op te nemen.

Verder werd nagegaan of de veronderstelling van de onderzoeker, dat het voorkomen van positieve kweekuitslagen groter zou zijn in de gezinnen waar wel een uitbreiding van de klacht voorkwam ten opzichte van de gezinnen waar de klacht zich maar tot één persoon (de patient) beperkte, bevestigd kon worden.

In de gezinnen waarbij behalve de patient meer personen diarree hadden, werd bij $32,1 \%$ een positieve kweekuitslag van de faeces verkregen. In de gezinnen waar één persoon de klachten had, werd in $32,8 \%$ een positieve kweekuitslag ontvangen.

Bevestiging voor de juistheid van deze veronderstelling kon in dit onderzoek dus niet geleverd worden.

De vraag aan de patient in de anamnese: zijn er thans nog personen met diarree, gaf eerder de omvang van de klacht aan dan dat het een signaal was voor het voorkomen van specifieke verwekkers. Om dit laatste te onderzoeken zal men systematisch onderzoek moeten verrichten. 
4.5. Handelen van de huisarts. De zorgverlening.

\section{Inleiding}

De huisarts wordt maar door een deel van de patienten met acute diarree om hulp gevraagd. De resultaten van het onderzoek naar het voorkomen van diarree in het gezin (zie par. 4.4) zijn daarvan ondermeer het bewijs. Patienten zullen veelal eerst zelf trachten het probleem op te lossen en meestal is de klacht van dien aard dat het inschakelen van de huisarts niet nodig is.

In dit hoofdstuk wordt ingegaan op verschillende aspecten van het handelen van de huisarts, indien er toch een beroep op hem of haar wordt gedaan. Aan de orde komen het lichamelijk onderzoek, het laboratoriumonderzoek, de ernst en de besmettelijkheid van de klacht, alsmede informatie over de voorlichting. Bij de analyse is gebruik gemakt van gegevens verkregen van het door de huisarts ingevulde formulier bij de aanvraag van de faeceskweek (zie par. 3.4.) maar ook van de gegevens, verkregen via de telefonische enquete. De aspecten betreffende de voorlichting over de klacht aan de patient zijn afkomstig van de enquete en zijn als zodanig door de onderzoeker voorgestelde mogelijkheden, die tot deze rubriek gerekend kunnen worden. In het bovenstaande kan tevens de verklaring gevonden worden van het wisselend aantal respondenten. Bovendien werd niet elk formulier altijd volledig door de huisarts ingevuld.

\section{-lichamelijk onderzoek-}

Van de patienten met de klacht acute diarree, die op het spreekuur kwamen werd $79.4 \%$ lichamelijk onderzocht. Afhankelijk van het symptomencomplex werden een aantal fysische diagnostische handelingen verricht. Bij 88.68 van de onderzochte patienten, werd een onderzoek van het abdomen uitgevoerd. Dit cijfer toonde 
een gelijke verdeling over de leeftijdsgroepen. Bij de overige $11,4 \%$ werd onderzoek verricht van 0.a. het keel-, neus- en oorgebied, hart en/of longen.

In de tabel 4.5 .1 wordt het percentage patienten bij wie een lichamelijk onderzoek werd verricht weergegeven, verdeeld over twee leeftijdsgroepen.

TABEL 4.5 .1

Percentage spreekuur-patienten bij wie lichamelijk onderzoek (1.0.) verricht werd, verdeeld naar leeftijdsgroepen, kinderen en volwassenen.

$(\mathrm{N}=354)$

lichamelijk

onderzoek (1.0.)

wel 1.0 .

geen 1.0 . kinderen

$\mathrm{n}=112$

81,2

18,8 volwassenen $\mathrm{n}=242$

Een aantal zaken vallen op bij de bestudering van deze cijfers.

Allereerst zou het te verwachten zijn, dat vooral bij kinderen het lichamelijk onderzoek een belangrijke rol speelt. Met name bij kinderen is het gevaar van uitdroging van meer importantie dan bij de groep volwassenen. Toch worden de genoemde groepen in de zelfde frekwentie door de huisarts onderzocht.

Vervolgens kwam in dit onderzoek naar voren, dat $16,1 \%$ van de totale patientengroep die kontakt opnam met de huisartspraktijk in eerste instantie via de telefoon van advies werden voorzien $(11,1 \%$ kinderen, $17,8 \%$ volwassenen).

Hierbij moet worden opgemerkt dat dit percentage betrekking heeft op de eerste raadpleging van de patient of diens verzorger. Er is geen informatie verzameld over een eventueel verricht lichamelijk onderzoek op later datum. Niettemin is vooral het gegeven dat 29,98 van de kinderen in dit onderzoek bij het eerste 
appèl niet werden onderzocht interessant tegen de achtergrond van opmerkingen $t . a \cdot v$. dit punt gemakt door de deelnemers aan de Nijmeegse huisartsgeneekundige konferenties. Daar werd gesteld, dat de hulsarts bij kinderen met acute gastro-enteritis de patient altijd persoonlijk zou moeten zien. (zie hoofdstuk 2.2.)

\section{- labora toriumonderzoek-}

Het zal geen nieuwtje zijn vast te stellen dat de huisarts vrijwel nooit laboratoriumonderzoek verricht of laat verrichten bij patienten met de klacht acute diarree met uitzondering van een faeceskweek. In dit onderzoek werd niettemin toch nagegaan hoe waar deze algemeen aanvaarde stellingname was. Dit onderdeel werd uitgesplitst in twee categoriëen: eigen laboratoriumonderzoek en uitbesteed laboratorium onderzoek.

Met de vraag naar eigen laboratoriumonderzoek werd getracht na te gaan of een observatie van de kleur, bijmengingen of urine onderzoek en/of bloedonderzoek bijvoorbeeld in de zin van de bloedbezinking (BSE), door de huisarts werden verricht.

Slechts in $2 \%$ werd een eigen laboratoriumonderzoek verricht en in 3,78 werd uitbesteed laboratoriumonderzoek aangevraagd, waarmee bedoeld worden de routinebepalingen, die iedere huisarts bij een streeklaboratorium kan aanvragen.

Ten aanzien van het eigen laboratoriumonderzoek nog het volgende.

Het is niet aannemelijk te veronderstellen dat de huisarts de patient vraagt een klein beetje faeces mee te nemen naar het spreekuur, om er vervolgens na beschouwing geen verslag van te doen in de registratie. Ook zullen patienten meestal niet gewoon zijn op eigen gezag een monster mee te nemen op het spreekuur. Het tegenovergestelde zal veeleer waar zijn. Met andere woorden de huisarts gaat af op de mededeling van de patient dat hij of zij diarree heeft en ziet waarschijnlijk vrijwel 
nooit zelf de ontlasting. Dit is des te opmerkelijker, omdat (acute) diarree mogelijk een van de weinige klachten is waarvan een zichtbaar bewijs is te leveren, wardoor onder andere definieringsproblemen aanzienlijk minder zouden bestaan. Een eenvoudige observatie zou eventuele bijmengingen direct onder ogen brengen.

\section{-ernst van de klacht-}

In hoofdstuk 2 werd vermeld dat de huisarts zich in de diagnostiek met betrekking tot deze klacht bedient van een veelheid van aanduidingen. De huisarts zal in eerste instantie vooral willen weten of bij een bepaalde klacht of symptomencomplex een therapeutische interventie noodzakelijk is. Een etiologische diagnose kan hierover uitsluitsel geven, maar veelal ook niet.

Het stellen van een dergelijke diagnose geeft onvoldoende inzicht over de aard van de klacht wat ernst of besmettelijkheid betreft.

Het is aannemenlijk dat deze laatste onderdelen veelmeer bepalend zijn voor een therapeutische aktie dan alleen een zuiver etiologische diagnose, te meer daar een bevestiging daarvan door het inzenden van kweekmateriaal meestal 5-7 dagen op zich laat wachten.

Tabel 4.5.2 geeft de resultaten van de beoordeling van de ernst van de klacht door de huisarts, verdeeld over de leeftijdsgroepen.

TABEL 4.5 .2

Oordeel van de huisarts over de ernst van de klacht in het eerste kontakt met de patient, in procenten bij een verdeling over twee leeftijdsgroepen.

$(\mathrm{N}=389)$

ernst $v / d$ klacht kinderen

$$
\mathrm{n}=131
$$

$\begin{array}{rr}34,4 & 23,3 \\ 64,8 & 70,5 \\ 0,8 & 6,2\end{array}$

volwassenen $\mathrm{n}=258$

gering

matig

ernstig

0,8

6,2 
Tabel 4.5.3 toont de afzonderlijke resultaten in procenten van de 11 praktijken uit groep $A$, wanneer het begrip ernst van de klacht wordt verdeeld in: gering en matig/ernstig.

TABEL $4 \cdot 5 \cdot 3$

Percentage patienten, met een geringe of matig/ernstige klacht naar inschatting van huisartsen uit 11 praktijken in groep $A$, verdeeld naar twee leeftijdsgroepen. $(\mathrm{N}=389)$

kinderen

$\mathrm{n}=131$

ernst van

de klacht

huisartspraktijk

I

I I

I I I

IV

V

VI

VII

VIII

IX

$\mathrm{X}$

XI
$42,9 \quad 57,1$

27,0

73,0

$33,3 \quad 66,7$

$21,1 \quad 78,9$

$52,4 \quad 47,6$

$36,1 \quad 63,9$

$60,0 \quad 40,0$

$22,2 \quad 77,8$

4,6

100

$33,3 \quad 66,7$

56,5

43,5

$50,0 \quad 50,0$

$71,4 \quad 28,6$

13,0

87,0

6,1

93,9

16,7

83,3

$-$

100

$33,3 \quad 66,7$

$21,4 \quad 78,6$

- 100

$25,0 \quad 75,0$

De resultaten tonen nogal een verschil tussen de diverse praktijken. Toch kan men vaststellen, dat ongeacht de leeftijd, de huisarts de 
klacht bij de meerderheid van zijn patienten als matig tot ernstig van aard aanduidt.

In tabel 4.5 .4 worden de resultaten getoond van de beoordeling van de besmettelijkheid van de klacht door de huisarts, verdeeld over twee leeftijdsgroepen.

TABEL 4.5 .4

oordeel van de huisarts over de besmettelijkheid van de klacht in het eerste kontakt met de patient in procenten bij een verdeling over twee leeftijdsgroepen.

$(\mathrm{N}=373)$

besmettelijkheid

kinderen

volwassenen

$\mathrm{n}=128$

$n=245$

gering

85,9

85,3

matig

1,6

0,8

ernstig

12,5

13,9

De cijfers tonen, dat in tegenstelling tot de ernst van de klacht bij een zeer groot deel van de patienten de klacht door de huisarts maar weinig besmettelijk wordt geacht.

Het is aannemelijk te veronderstellen, dat bij het beoordelen van de besmettelijkheid door de huisarts etiologisch wordt gedacht. Bij de beoordeling van de ernst zal waarschijnlijk de totale situatie van de patient aangeduid worden. De huisarts zal, om enige aanwijzingen te hebben over de besmettelijkheid, in de anamnese vragen stellen over onder meer het bestaan van koorts, bloedbijmenging, het voorkomen van diarree bij andere gezinsleden en dergelijke, kortom zaken die bekend staan als bepalend voor een infektieuze diarree. In dit kader was het interessant na te gaan of de huisarts op grond van de beoordeling van de mate van besmettelijkheid enige voorspelling kan doen over de kweekuitslag.

Tabel 4.5 .5 toont de resultaten indien men de 
mate van besmettelijkheid ingeschat door de huisarts in verband brengt met de kweekuitslag in de kindergroep.

TABEL 4.5 .5

Kruistabel van mate van besmettelijkheid volgens oordeel van de huisarts in verband met de kweekuitslag bij kinderen

$(\mathrm{N}=127)$

mate van besmettelijkheid volgens

de huisarts

gering

matig/ernstig positieve

kweekuitslag kweekuitslag negatieve
45

4

49
66

12

78

chi kwadraat $=1,42$ p>0, 1

Tabel 4.5 .6 toont de resultaten m.b.t. de volwassenengroep.

TABEL 4.5 .6

Kruistabel van mate van besmettelijkheid volgens oordeel van de huisarts in verband met de kweekuitslag bij volwassenen.

$(\mathrm{N}=245)$

mate van besmet-

telijk-

heid volgens

huisarts

gering

matig/ernstig positieve negatieve

kweekuitslag kweekuitslag

44

172

216

10

19

54

191

245

chi kwadraat $=2,94 \quad p>0,05$ 
Voor beide leeftijdskategoriëen blijkt dat ex geen samenhang bestaat in de beoordeling van de besmettelijkheid door de huisarts en de kweekuitslag. Ook een nadere analyse van de kweekuitslag in de $z$ in van positief bakterieel en positief viraal bracht geen signifikantie aan het licht. Het ziet er naar uit dat het vrijwel ondoenlijk is uit de anamnese aanwijzingen voor infektieusiteit van de klacht acute diarree te vinden. De anamnese laat hierover geen konklusie toe en is daarvoor kennelijk geen geschikt instrument.

Het laten kweken van de faeces bij acute diarree door de huisarts heeft in het algemeen weinig zin, behalve dat in bepaalde situaties m.n. bij 2 of meer ziektegevallen in het gezin (besloten woongemeenschappen, kindertehuizen, bejaardenoorden) het wel aan te bevelen is bij patienten met acute diarree een faeceskweek te laten verrichten. Door deze snelle opsporing kunnen vroegtijdig eventuele microorganismen worden ontdekt en kan bij adekwat handelen een explosie worden beperkt of zelfs worden voorkomen.

\section{-behandelingsplan-}

Bij het opstellen van een behandelingsplan zijn in dit onderzoek een aantal onderdelen onderscheiden.

Voorop staat het vochtgebruik als belangrijk onderdeel van de advisering van de huisarts. Veelal makkt dit deel uit van de richtlijnen met betrekking tot het dieet, waarmee doorgaans bedoeld wordt, wat men wel en wat men niet zou moeten eten en arinken bij deze klacht.

Vervolgens gaat het om het voorschrijven van farmacotherapie door de huisarts.

Het derde aspekt heeft betrekking op de voorlichting c.q. uitleg over de klacht aan de patient in het kontakt met de huisartspraktijk. Afspraken van de huisarts met de patient over een eventuele kontrole zijn in dit onderzoek niet nader geanalyseerd. Wel is gebleken, 
dat er een grote mate van verschil in opvatting over de afspraken bestond tussen beiden.

De noodzaak van het voorschrijven c.q. bespreken van een diëet door de huisarts lijkt bij deze klacht onbetwistbaar. Niettemin bestond bij de onderzoeker de interesse of een dergelijke opvatting met de werkelijkheid overeen stemde. Volgens opgave van de huisartsen in dit onderzoek werd aan $97,1 \%$ van de patienten een dieet voorgeschreven $\mathrm{c.q}$. met hen besproken. Ook aan de patient of diens verzorger werd in de telefonische enquête een vraag gesteld over dieetadviezen van de huisarts

Tabel 4.5 .7 geeft de resultaten $t . a \cdot v$. de meningen van de huisarts en de patient over dit onderdeel weer voor de kindergroep.

TABEL 4.5 .7

Kruistabel van opgave dieetadviezen volgens huisarts versus opgave van dieetadvies volgens patient (kinderen)

$(\mathrm{N}=105)$

dieetadvies

opgave ontvangen dieetadviezen patient

opgave dieetadv. geen adv. wel adv. huisarts

geen advies

1

wel advies 
Tabel 4.5.8 geeft de resultaten weer van de ontvangen dieetadviezen in de volwassenengroep.

TABEL 4.5 .8

Kruistabel opgave dieetadviezen volgens huisarts versus opgave van dieetadviezen volgens patient (volwassenen) $(\mathrm{N}=204)$

opgave

dieetadviezen

huisarts opgave ontvangen dieetadviezen patient

geen advies wel advies geen advies

wel advies
32

Toch gaven 8 kinderen of hun verzorgers en 30 volwassenen op geen dieet voorgeschreven gekregen te hebben of er met de huisarts over gesproken te hebben.

Farmacotherapie bij acute diarree eist een belangrijke plaats op in het behandelingsplan van de huisarts in dit onderzoek. Volgens opgave van de huisarts werd aan ruim $75 \%$ van de patienten farmacotherapie voorgeschreven. Tabel 4.5.9 toont de resultaten van het percentage patienten, dat medicijnen voorgeschreven kreeg, verdeeld over twee leeftijdsgroepen. De percentages in deze tabel werden rechtstreeks verkregen van de patient of diens verzorger via de telefonische enquête ( $N=481)$. Het totale percentage van ruim 758 is daardoor niet veranderd. 
TABEL $4 \cdot 5 \cdot 9$

Percentage patienten dat farmacotherapie voorgeschreven heeft gekregen, verdeeld over twee leeftijasgroepen

$(\mathrm{N}=481)$

\section{opgave}

farmacotherapie

kinderen $\mathrm{n}=157$

58,6

41,4 volwassenen

$n=324$

wel medicijnen

geen medicijnen

84

16

Het voorschrijven van farmacotherapie is een handeling waarbij een tastbaar bewijs met name een recept wordt overhandigd. In die zin zou hierover geen onduidelijkheid moeten kunnen bestaan. In dit onderzoek werd nagegaan of deze konstatering met de werkelijkheid overeen kwam.

In tabel $4.5 .10 \mathrm{zijn}$ de resultaten opgenomen wanneer men de opgave van de huisarts in verband brengt met die van de patient of diens verzorger.

TABEL $4.5 \cdot 10$

Kruistabel opgave medicijn voorschrift huisarts versus de opgave ontvangen med. volgens patient. $(\mathrm{N}=463)$

opgave farmacotherapie huisarts

geen med. wel med. opgave farmacotherapie patient

geen med. wel med.

102

10

12

339

349
112

351 463 
Opvallend is dat 10 patienten zeggen wel medicijnen te hebben ontvangen, terwijl de huisarts opgeeft deze niet te hebben voorgeschreven. Daar tegenover staan 12 patienten die het omgekeerde beweren. In meer dan $95 \%$ van de gevallen, waarin de huisarts of via hem de assistente opgaf een recept te hebben verstrekt, werd dit door de patient bevestigd.

Uit de cijfers blijkt dat in de volwassen groep meer dan $80 \%$ van de patienten met de klacht acute diarree een medicijn voorgeschreven kreeg. Voorwaar geen gering percentage, dat nog een speciale dimensie krijgt tegen de achtergrond van de alom aanwezige opvatting onder artsen, dat acute diarree een zichzelf limiterende klacht is. Het percentage van bijna 608 medicijnvoorschrift bij kinderen is evenmin te veronachtzamen. In de rubriek medicijnen werden alle medicatievoorschriften van de huisartsen ondergebracht i.v.m. deze klacht. Hieronder bevonden zich ook koortsdrukkende middelen, spasmolytica en sporadisch een antibioticum. Het leeuwenaandeel van het medicijnvoorschrift door de huisarts bij deze klacht werd echter ingenomen door de stopmiddelen.

In dit onderzoek bleek dat, indien het om stopmiddelen ging door de huisarts voorname$1 i j k$ van 3 preparaten met name loperamide; tannalbine en tct. opii crocata gebruik werd gemaakt.

Deze preparaten maakten $80 \%$ uit van het medicijnvoorschrift van de huisarts bij de klacht acute diarree, waarbij loperamide het meest werd voorgeschreven. Daarnaast maakte iets meer dan een kwart van de patienten $(25,3 \%)$ gebruik van zelfgekochte $\mathrm{s}$ topmiddelen met als favoriet preparaat Norit .

-voorlichting-

Bij de behandeling van de klacht acute diarree werd niet volstaan met een dieet en of het voorschrijven van een stopmiddel, alhoewel deze zaken tot de routinebehandeling bleken te 
behoren. Vooral bij deze klacht was het aannemelijk te veronderstellen, dat er tijdens het kontakt met de praktijk gesproken zou worden over de aard van de aandoening.

De huisartsen in dit onderzoek gaven op in $69 \%$ van de gevalien voorlichting aan de patient of diens verzorger te hebben verschaft. Bij de onderzoeker bestond ten aanzien van dit onderdeel van het behandelingsplan de interesse wat de ervaring van de patient c.q. verzorger was op dit punt.

Nu is het evenwel zo, dat niet precies is aan te geven wat de huisarts en de patient onder voorlichting verstaan. De opgave van patienten c.q. verzorgers over het wel of niet verkregen hebben van voorlichting liepen sterk uiteen met die van de huisartsen. zo vond bijvoorbeeld 448 van de patienten, die volgens de huisarts voorlichting had ontvangen, zelf echter hiervan verstoken te zijn gebleven. De gevolgde onderzoeksmethode legt een grote beperking op met betrekking tot de interpretatie van de cijfers voor dit onderdeel voorlichting. In dit onderzoek werd daarom dit begrip inhoud gegeven, waarbij een keuze door de onderzoeker werd gemaakt uit de elementen van de voorlichting, waarvan verwacht mocht worden dat deze in de uitleg door de huisarts een belangrijke rol zouden spelen. Het onderdeel voorlichting werd daartoe opgesplitst in a) besmettelijkheid; b) hygiëne; c) werk (zie bijlage III). Begrippen a) en b) spreken voor zichzelf, met c) werd adviezen met betrekking tot het hervatten van de dagelijkse bezigheden bedoeld, ongeacht of deze beroepsmatig waren of niet. Strikt genomen zou dit laatste punt niet tot de voorlichting gerekend kunnen worden. Toch werd het aan de orde stellen van dit aspekt door de huisarts van belang geacht voor een behandelingsplan.

Het betreft hier dus de resultaten van de antwoorden op vragen van de onderzoeker aan patienten over welke aspekten in de voorlichting al dan niet aan de orde zijn gesteld door 
de huisarts. Het is geen weergave van een opgave van de huisartsen zelf.

De aspekten besmettelijkheid en hygiëne worden afzonderlijk bij iets meer dan 17 g van de patienten aan de orde gesteld $(n=40$ resp. $\mathrm{n}=38$ ). Het percentage patienten dat tegelijkertijd over beide aspekten informatie krijgt, is maar weinig hoger namelijk $20,58 \quad(n=46)$. Bij $20,1 \% \quad(n=45)$ van de patienten werden alle drie aspekten van de voorlichting als informatie aangeboden.

Samenvattend voor het onderdeel voorlichting kan men stellen, dat in dit onderzoek bij meer dan de helft van de patienten met acute diarree, die kontakt opnamen met de huisartspraktijk volgens opgave van de patienten niet gesproken werd over de eventuele besmettelijkheid van de klacht, noch over hygienematregelen, noch over het tijdstip waarop de patient weer kon gaan werken of naar school kon gaan. Bij $40 \%$ van de patienten, die wel informatie ontvingen werd zowel gesproken over de besmettelijkheid van de klacht als over hygiënemaatregelen.

\section{-kontaktvorm-}

Het kontakt van de patient met de huisartspraktijk kan op verschillende manieren tot stand komen, b.v. na een konsult of een visite van de huisarts, maar ook via een tellefonisch overleg met de huisarts of de doktersassistente of een kontakt aan de receptiebalie. In dit onderzoek werd vastgelegd, hoe vaak patienten op de bovengenoemde wijze kontakt hadden opgenomen met de huisartspraktijk. De achtergrond van deze registratie is gelegen in het pogen aan te tonen, dat een op het oog eenvoudige klacht als acute diarree voor de huisarts een behoorlijke werklast in de zin van een frekwent aantal kontakten van verscheidene aard met zich meebrengt.

Tabel 4.5.11 geeft een overzicht van de ver- 
schillende kontaktvormen. In de rubrieken konsult, visite, receptiebalie en telefoon gaat het om patienten die geen andere kontaktvorm hadden dan de gerubriceerde. Er kwamen echter ook kombinaties voor. In deze rubrieken is alleen het type kombinatie geregistreerd. Een differentiatie van de onderdelen van een kombinatie is niet verder uitgewerkt. Met andere woorden een kombinatie -konsult en telefoon- betekent minstens 1 konsult en 1 telefonisch konsult, maar het kan ook meer dan één betekenen.

Alle voorgekomen kombinaties in dit onderzoek zijn in tabel 4.5.11 opgenomen.

TABEL 4.5 .11

Aantal patienten en het aantal kontaktvormen verdeela over twee leeftijdsgroepen.

$(\mathrm{N}=475$ )

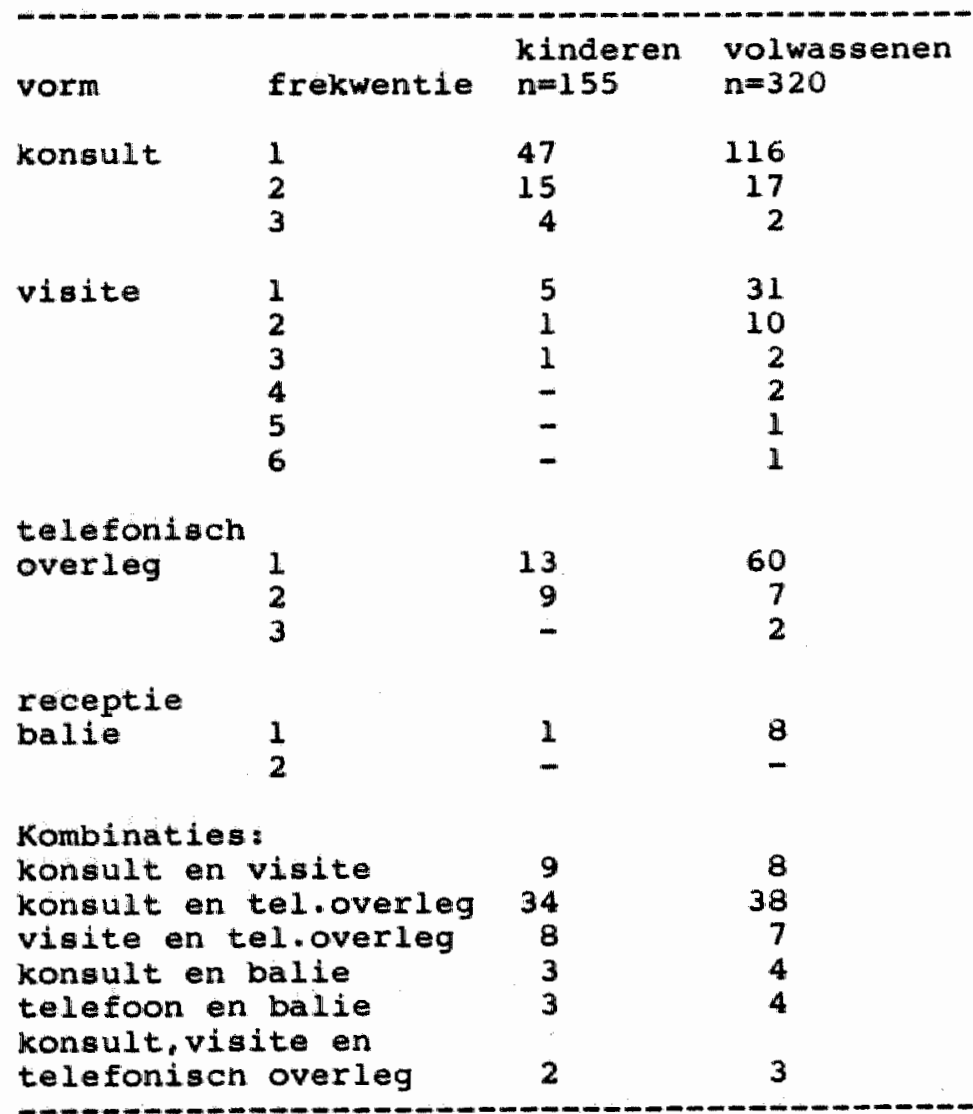


Ruim 348 van de patienten komt voor de klacht acute diarree slechts eenmal op het spreekuur. Een eenmalige visite legde de huisarts af bij ruim 78 van de patienten. Opvallend hierbij is dat meer volwassenen dan kinderen thuis werden bezocht.

Het telefonisch overleg is een veel gebruikte vorm bij deze klacht. Ruim 158 van de patienten volstond met een eenmalig telefonisch kontakt. Tevens bleek dat hetzelfde percentage patienten zowel via de telefoon als in de spreekkamer om advies vroegen. In deze kombinatie kan het meerdere konsulten of telefoongesprekken betreffen.

om enig inzicht te hebben in de telefonische belasting van de praktijk t.a.v. deze klacht werd het aantal telefonische konsultaties van de totale groep van 475 patienten geregistreerd. Er werden 197 telefoongesprekken gevoerd.

Nabeschouwing

Het handelen van de huisarts bij de klacht acute diarree werd op een aantal onderdelen geanalyseerd.

Er werd gebruik gemaakt van gegevens verstrekt door de huisarts en van gegevens over dezelfde onderdelen maar nu rechtstreeks verkregen van de patient of diens verzorger.

$B i j$ de beschrijving van het handelen van de huisarts bij deze klacht werd in dit onderzoek allereerst nagegaan, bij hoeveel patienten een lichamelijk onderzoek werd verricht. van de patienten die de huisarts inschakelen werd 79,4 을 lichamelijk onderzocht en daarbij ging het in 88,68 onder meer om een onderzoek van het abdomen. Kinderen en volwassenen werden in gelijke mate lichamelijk onderzocht. Bij 13,98 van de patienten werd vooralsnog geen fysisch diagnostisch onderzoek verricht, omdat de huisarts deze patienten niet persoonlijk zag. Hiermee worden de patienten bedoeld, die in eerste instantie per telefoon te woord worden gestaan. 
Huisartsen verrichtten vrijwel nooit (98\%) eigen laboratorium onderzoek bij de klacht acute diarree en vroegen ook maar zelden laboratoriumonderzoek aan $(3,78)$. Waarschijnlijk observeerden zij zelden of nooit de ontlasting bij de klacht acute diarree. Het is aannemelijk te veronderstellen, dat besmettelijkheid en microbiêle etiologie een duidelijke relatie hebben. Toch kon de huisarts met behulp van zijn schatting van de besmettelijkheid van de klacht, niet voorspellen of hij met een positieve of negatieve kweekuitslag te doen had.

Ten aanzien van het behandelingsplan was het met betrekking tot het dieetadvies toch opvallend, dat 8 kinderen en 30 volwassenen meedeelden hierover geen informatie ontvangen te hebben. Er kan natuurlijk sprake zijn dat de huisarts ervan uitging dat de dieetvoorschriften wel bekend waren bij de patienten. Alhoewel niet systematisch geinventariseerd wordt deze veronderstelling door de onderzoeker onwaarschijnlijk geacht.

Bij het voorschrijven van de farmacotherapie was de konsensus tussen huisarts en patient groter, $95 \%$ van de patienten was het met de huisarts eens en gaf aan een recept ontvangen te hebben. Opmerkelijk was het hoge aantal medicijnvoorschriften bij deze klacht in beide leeftijdskategoriën ( 598 bij de kinderen en 848 bij de volwassenen), ondanks de algemeen bekende opvatting onder huisartsen, dat acute diarree een zichzelf limiterende ziekte is. Daarmee is niet gezegd dat stopmiddelen, die het leeuwenaandeel van het medicijnvoorschrift voor hun rekening nemen, geen effekt zouden hebben.

De cijfers over de voorlichting in dit onderzoek geven aan dat iets meer dan de helft van de patienten volgens eigen opgave in ieder geval geen informatie kreeg over aspekten als besmettelijkheid, hygiëne en hervatten van de dagelijkse bezigheden. 
Tenslotte kan worden gezegd, dat het verzamelen van gegevens over voorlichting door middel van een follow-up onderzoek een element van onnauwkeurigheid met zich kan meebrengen. De cijfers van de resultaten van dit onderdeel moeten tegen deze achtergrond beschouwd worden.

Daarbij komt dat het lang niet altijd zeker is dat de huisarts en de patient nagaan of de aangeboden informatie begrijpelijk is. In die zin verdient het aanbeveling, dat de huisarts in zijn behandelingsplan bij deze klacht de verstrekte adviezen met schriftelijke informatie ondersteunt. 
HOOFDSTUK 5: MICROBIELE OORZAKEN VAN DE KLACHT (ACUTE) DIARREE.

\subsection{Inleiding}

Microbiële agentia spelen een belangrijke rol bij het veroorzaken van diarree $(1,2,3,4)$. Het detekteren van micro-organismen in de faeces van patienten met (acute) diarree levert op zich maar een deel van het bewijs met een microbiële verwekker te doen te hebben.

Strikt genomen zou de huisarts in zijn diagnostiek niet kunnen volstaan met het aantonen van een micro-organisme in de faeces. Met behulp van een serologische titerstijging zou zijn vermoeden, dat een microbieel agens de mogelijke verwekker is, bevestigd kunnen worden. In de huisartspraktijk wordt bij deze klacht (vrijwel) nooit een dergelijke bepaling aangevraagd. In de opzet van dit onderzoek is uitgegaan van de reële situatie in de huisartspraktijk ten aanzien van het aanvragen van microbiologisch onderzoek. Mede om deze reden is een serologische titerbepaling niet in het onderzoeksprotokol opgenomen.

In dit hoofdstuk zal een beschrijving gegeven worden van het voorkomen van microbiële agentia bij patienten met acute en patienten met acute als iets langer durende diarree in de huisartspraktijk. Tevens wordt aandacht besteed aan de mogelijkheden van de huisarts om met behulp van zijn gebruikelijke werkwijze (op indikatie) een onderscheid aan te brengen t.a.v. het voorkomen van microbiële agentia.

\subsection{Opzet}

De huisarts zal meestal niet in het eerste kontakt met een patient met acute diarree besluiten tot het aanvragen van een faeceskweek. Veelal zal de huisarts bij het aanhouden of verergeren van de klacht overwegen, of hij door kennis te hebben van het aanwezig zijn van een microbiëel agens, de tot nu toe 
gevolgde behandeling zal moeten wijzigen. Om na te kunnen gaan in hoeverre de via dit patientenmateriaal verkregen frekwentieverdeling van voorkomen van microbiële agentia, afwijkt van de frekwentieverdeling van alle patienten met diarre werd als volgt gehandeld: er werd een vergelijking gemakt tussen de resultaten van het voorkomen van microbiële agentia in groep $A$ en groep B (zie ook hoofdstuk 3). In groep A was sprake van een populatie van 589 personen, waarbij de microbiële bepalingen volgens een standaard-procedure werden verricht.

In groep $B$, bestaande uit 264 personen, was dit niet het geval, in die zin dat de huisartsen in deze groep louter op indikatie één of meer microbiële bepalingen aanvroegen, hetgeen betekende een wisselend aantal aanvragen c.q. kweekuitslagen.

Zo werden Salmonella/Shigella-onderzoek bij deze groep patienten bijna altijd aangekruist en dat gold in zekere zin ook voor Campylobacter jejuni. Verzoeken om onderzoek echter naar het voorkomen van Yersinia enterocolitica en wormeieren en kysten werden aanzienlijk minder verlangd.

Een tweede opmerking met betrekking tot de microbiële diagnostiek heeft betrekking op de virologie.

Huisartsen in de regio Mastricht vragen nooit een virrologisch onderzoek aan bij de klacht acute diarree. Toch werd in dit onderzoek in de groep A-monsters een uitgebreide screening gedaan naar het voorkomen van virussen bij acute diarree. Om een vergelijking tussen de groepen $A$ en $B$ te kunnen maken was het wenselijk, dat voor de monsters uit groep $B$ eenzelfde standaardprocedure ten aanzien van de virologie als voor groep A zou worden gevolgd. Er werd als volgt gehandeld: uit de totale groep B van 264 patienten werd bij 113 in eerste instantie ontvangen monsters dezelfde virologische bepalingen verricht als bij alle patienten van de huisartsen uit groep $A$. Van belang bij deze gang van zaken was de mate van 
vergelijkbaarheid van de patienten uit deze twee groepen. Dit probleem werd als volgt aangepakt. Nagegaan werd hoe de percentuele verdeling van de patienten uit groep $A$ en $B$ zich verhield ten aanzien van de 7 leeftijdskategorieën (zie tabel 5.2.1). Zie ook hoofdstuk 4.1 ).

TABEL $5.2 \cdot 1$

Percentage patienten, verdeeld over 7 leeftijdskategoriën met een standaard kweekprocedure (Groep $A$ ) en een kweek op indikatie (Groep B).

leeftijd

$0-12$ mnd.

$1 \mathrm{t} / \mathrm{m} 4 \mathrm{j}$.

$5 \mathrm{t} / \mathrm{m} 10 \mathrm{j}$.

$11 \mathrm{t} / \mathrm{m} 30 \mathrm{j} \cdot 28.3$

$31 \mathrm{t} / \mathrm{m} 50 \mathrm{j} \cdot 22.4$

$51 \mathrm{t} / \mathrm{m} 70 \mathrm{j} \cdot 13.5$

$>71 \mathrm{j}$.

$4 \cdot 8$ groep $\mathrm{B} N=264$ $\%$ pat.

$$
4.5
$$

19.7

$4 \cdot 2$

$32 \cdot 2$

$22 \cdot 4$

13.6

$3 \cdot 4$

Vervolgens werd nagegaan hoe de verdeling van het aantal patienten over de leeftijdskategorieën er litzag, indien men de onderzochte faecesmonsters in groep $B$ afzonderlijk in ogenschouw nam. 
TABEL $5.2 \cdot 2$

Leeftijdsverdeling in percentages van patienten bij wie het faecesmonster op indikatie werd onderzocht op resp. Salm./Shig./Campylobacter/Yersinia en waarbij een standaard virologisch onderzoek werd verricht.

\begin{tabular}{|c|c|c|c|c|c|}
\hline leeftijd & $\begin{array}{l}\mathrm{n}=257 \\
\text { Salm. }\end{array}$ & $\begin{array}{l}n=257 \\
\text { Shig. }\end{array}$ & $\begin{array}{l}\mathrm{n}=230 \\
\text { Camp. }\end{array}$ & $\begin{array}{l}n=123 \\
\text { Yers. }\end{array}$ & $\begin{array}{l}n=113 \\
\text { Virol. }\end{array}$ \\
\hline 0-12 mnd. & 4.7 & $4 \cdot 3$ & 4.8 & 5.7 & 4.4 \\
\hline $1 \mathrm{t} / \mathrm{m} 4 \mathrm{j}$. & 19.8 & 19.4 & 19.6 & $21 \cdot 1$ & 20.3 \\
\hline $5 \mathrm{t} / \mathrm{m} 10 \mathrm{j}$. & $4 \cdot 3$ & $4 \cdot 3$ & $4 \cdot 3$ & 6.5 & 3.5 \\
\hline $11 \mathrm{t} / \mathrm{m} 30 \mathrm{j}$. & 31.1 & 31.9 & $31 \cdot 3$ & 22.8 & 28.3 \\
\hline $31 \mathrm{t} / \mathrm{m} 50 \mathrm{j}$. & 22.6 & $22 \cdot 6$ & 23.5 & 22.0 & $28 \cdot 3$ \\
\hline $51 \mathrm{t} / \mathrm{m} 70 \mathrm{j}$. & 14.0 & 14.0 & 13.9 & 13.8 & 10.6 \\
\hline$>71 \mathrm{j}$ & 3.5 & 3.5 & 2.6 & 8.1 & 4.4 \\
\hline
\end{tabular}

Zoals uit tabel 5.2 .1 en 5.2 .2 blijkt vertonen groep $A$ en $B$ niet alleen een overeenkomstige verdeling van het percentage patienten over de 7 leeftijdskategorieën, indien de groepen in hun totaliteit bezien worden, maar de cijfers voor de afzonderlijke faeces-onderzoeken in groep B komen eveneens vrijj nauwkeurig overeen met die van groep A. Dit geldt niet alleen voor het percentage patienten, bij wie op verzoek van de huisarts een bakteriologische bepaling werd verricht, maar evenzeer voor het percentage patienten, waarbij, zonder dat dit door de huisarts werd verlangd, toch een virologische detektie werd uitgevoerd.

De geslachtsverdeling van de groepen $A$ en $B$ vertonen zowel voor de totale groep als voor de afzonderlijke kategoriën kweekaanvragen een konstante verhouding van ongeveer 608 (vrouwen) tot 408 (mannen).

Ten aanzien van de vergelijkbaarheid van de 
resultaten van de microbiële bepalingen van patienten met diarree is er tussen patienten van groep $A$ en $B$ een sterke mate van overeenkomst met betrekking tot de leeftijds- en geslachtsverdeling. Er moet evenwel in acht genomen worden dat de patienten van de huisartsen uit groep $A$ de klacht acute diarree presenteerden en de patienten van de huisartsen uit groep $B$ acute of iets langere diarreeklachten bezaten. Tevens kan ten aanzien van de vergelijkbaarheid van de groepen nog worden vermeld dat de verdeling van de praktijken over deze twee groepen, zowel wat de praktijkorganisatie (solo, groepspraktijk, associatie) betreft als de geografische ligging geen essentiële verschillen kende (zie hoofdstuk 3).

\subsection{Resultaten}

Groep $A$ is ten aanzien van de gevolgde standaardprocedure bij het kweken te beschouwen als een homogene groep. De bakteriologische en virologische kweekresultaten kunnen dan ook bij elkaar geteld worden ter verkrijging van een totaal percentage positieve c.q. negatieve kweekresultaten.

In groep $B$ is deze optelling niet te maken vanwege de geindiceerde aanvragen. Wel kan er voor de afzonderlijke faeces-onderzoeken een vergelijking gemaakt worden tussen de percentages van de positieve resultaten in groep $A$ en $B$.

In $37 \%$ werd er bij de patientengroep van de huisartsen van groep A een microbiëel microorganisme (bakterie of virus) gekweekt. Dubbelisolaten werden gevonden bij 3 volwassenen en 2 kinderen.

Tabel 5.3.1 geeft een overzicht van de positieve bakteriologische kweekresultaten van de faecesmonsters van patienten van de huisartsen van groep $A$, verdeeld over twee leeftijdskategoriëen, met name kinderen tot en met 10 
jaar en volwassenen gerekend vanaf 11 jaar en ouder.

TABEL 5.3 .1

Percentage positieve bakteriologische kweekresultaten, verdeeld over twee leeftijdskategoriën in groep $A$. $(\mathrm{N}=589)$

Kweekresultaten

kinderen $(n=182)$ volwassenen $(n=407)$

n 8 n

Salmonella

19

$10,4 \quad 30$

7,4

Shigella

0

0

1

0,2

Campylobacter

1910,4

61

15,0

Yers.enterocolitica

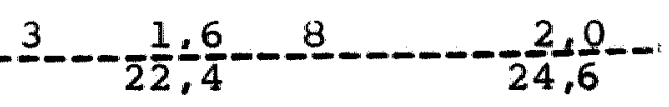

Het is opvallend, dat in de kindergroep Salmonella en Campylobacter fetus ssp jejuni percentueel in dezelfde mate voorkomen, terwijl in de volwassenengroep dit laatste micro-organisme bijna tweemal zoveel gekweekt wordt als de Salmonella bakterie. Campylobacter jejuni speelt uitgaande van het voorkomen bij acute diarree minstens zo'n belangrijke rol als de Salmonellae. Men zou kunnen stellen, dat van de zoönosen Campylobacter jejuni de salmonella in frekwentie heeft geëvenaard en wellicht reeds is voorbij gestreefd.

Yersinia enterocolitica komt over de hele linie maar in zeer geringe mate voor. De rol van dit micro-organisme moet bij acute diarree als gelimiteerd worden beschouwd.

Shigella komt slechts sporadisch in Nederland voor. Niettemin kan dit micro-organisme ernstige epidemiëen veroorzaken, vooral in gesloten woongemeenschappen (tehuizen). Een waakzame houding van de huisarts is vooral in derge- 
lijke situaties noodzakelijk.

In dit onderzoek werd in een periode van 13 maanden 1 shigella $(0,28)$ bij 589 patienten met acute diarree ontdekt., hetgeen als een bevestiging van de geringe incidentie van dit micro-organisme kan worden beschouwd.

Resumerend is uit tabel 5.3.1 af te lezen, dat bakteriologische micro-organismen in de kinder- volwassengroep in vrijwel dezelfde mate (resp. 22,48 en $24,6 \%$ ) voorkomen.

Tabel 5.3.2 geeft een overzicht van de virologische agentia, gedetekteerd in de faecesmonsters van patienten van de huisartsen in groep A.

TABEL $5 \cdot 3 \cdot 2$

Percentage positieve virologische kweekresultaten, verdeeld over twee leeftijdsgroepen in groep A

(virus ondef * betekent: ondefinieerbaar vanwege een overgroeien van het kweekmateriaal bakterieën) **

$(\mathrm{N}=571)$

kweekresultaten

kinderen $(n=176)$

n

23

10

5,7

1

volwassenen

$(\mathrm{n}=395)$

Rotavirus

Enterovirus

Adenovirus

5

2,8

0

0

Virus ondef n

8

$\begin{array}{lllll}5 & 2,8 & 20 & 5,1\end{array}$

* Het aantal aangevraagde viruskweken in groep $A$ is lager dan de bakteriologische kweken. De verklaring moet gezocht worden in het feit, dat in 18 gevallen het faecesmonster of niet op het virologisch laboratorium werd ontvangen ofwel dat er sprake was van een per abuis niet uitvoeren van de procedure. 
Met het voorkomen van virussen bij patienten met acute diarree is het duidelijk anders gesteld.

Tabel 5.3.2 laat zien dat virussen, dat wil zeggen die typen virussen die in dit onderzoek bepaald zijn, een voorkeur hebben voor de kindergroep. Het sterkst geldt dit voor het Rotavirus (5). In 21,58 bij kinderen met acute diarree is er sprake van een viraal agens tegenover 2,28 bij de volwassenen, warbij de niet te definiëren virustypen buiten beschouwing zijn gelaten.

Zoals in hoofdstuk 2 werd beschreven, is er getracht zoveel mogelijk virussen, die in verband met diarree gebracht kunnen worden, op te sporen. Het uiteindelijke resultaat laat zien dat slechts drie verschillende virussen worden gevonden (zie par. 5.3, tabel 5.3.5).

Resumerend kan gezegd worden, dat bij de patienten met acute diarree van groep $A$, die de hulp van de huisarts inriepen bij de volwassenen respektievelijk kinderen in 24,6 en 22,48 een bakterieel micro-organisme in de faeces werd ontdekt en in $2,2 \%$ respektievelijke $21,5 \%$ een viraal. In het totaal was er sprake van $37 \%$ positieve bakteriële en virale kweekuitslagen inklusief de niet te definiëren virussen.

Tenslotte werd nagegaan, welke typen salmonellae, Yersiniae en Shigellae er in dit onderzoek voorkwamen (Campylobacter werd uitsluitend gedetekteerd op Campylobacter fetus ssp jejuni).

Tabel 5.3.3 geeft een overzicht van de klassifikatie, waarbij voor de Salmonellae de faagtypering achterwege is gelaten. 
TABEL $5 \cdot 3 \cdot 3$

Opgave van het voorkomen van de bakteriële micro-organismen in groep $A$. naar groepen en typen

n

Groep B S. typhimurium

S. agona

s. heldelberg

geen typering

Groep C S. infantis

S. livingstone

s. braenderup

s. newport

Groep D

S. panama

S. dublin

Groep E S. London

Yersinia enterocol. Type 3

Shigella B flexneri type 3

Uit tabel 5.3 .3 blijkt duidelijk dat in dit onderzoek Salmonella typhimurium het meest voorkomende salmonella-type is bij patienten met acute diarree. Salmonella panama komt op de tweede plaats, hetgeen in overeenstemming is met de landelijke situatie. Yersinia enterocolitica komt in geringe mate voor, waardoor het interpreteren van de cijfers in tabel 5.3.3 onder voorbehoud dient te geschieden. Niettemin is het feit, dat type 3 meer voorkomt dan de andere typen een bevestiging van de literatuur $(6,7,8)$. Shigella flexneri 
behoort niet tot de zogenaande autochtonen in dit land. De patient, bij wie dit micro-organisme werd opgespoord, had kort voor haar vertrek van een vakantiebestemming in Portugal diarreeklachten gekregen. Tot zover de resultaten van het bakteriologisch en virologisch onderzoek van de faecesmonsters afkomstig van patienten van de huisartsen in groep $A$.

In tabel 5.3.4 wordt een overzicht gegeven van de positieve bakteriologische kweekresultaten van de faecesmonsters van patienten van de huisartsen in groep $B$ verdeeld in twee leeftijdsgroepen.

TABEL $5 \cdot 3 \cdot 4$

Percentage positieve bakteriologische kweekresultaten in groep $B$, verdeeld over kinderen en volwassenen

kinderen

$(\mathrm{N}=75)$ volwassenen

$$
(\mathrm{N}=189)
$$

n $\quad 8$

$$
12,2 \text { Salm. }(\mathrm{n}=183)
$$

$\operatorname{Salm} \cdot(n=74)$

Shig $\cdot(n=185)$

Camp. $(n=66)$

3,0 Camp $\cdot(n=166)$

1810,8

Yers.e. $(n=41) 1$

Uit tabel 5.3 .4 is af te lezen, dat bij patienten van wie op indikatie een faeceskweek werd verricht, Salmonella en Campylobacter het meest voorkwamen. De salmonellae kwamen bij deze kategorie patienten meer voor bij de kinderen dan bij de volwassenen (resp. 12,28 en 6,0\%). Bij Campylobacter was het beeld ongekeerd. Dit micro-organisme kwam percentueel 3 keer meer voor bij volwassenen dan bij de kinderen. Yersinia enterocolitica speelde ook bij deze groepen patienten een onderge- 
schikte rol, evenals shigella met in achtneming van wat eerder over de minimal infektieuze dosis van dit organisme werd gezegd. Ten aanzien van de beoordeling van deze percentages dient evenwel in aanmerking te worden gehouden, dat het om een getalsmatige benadering van de vergelijking gaat.

Tabel 5.3.5 geeft een overzicht van de virologische kweekresultaten van faecesmonsters van patienten van huisartsen in groep $B$, waarbij er, zoals reeds eerder vermeld, geen sprake is van een aanvraag voor virologisch onderzoek door de hulsarts, maar van een onderzoek bij in eerste instantie 113 patienten waarbij terwille van deze studie eveneens dezelfde virologische bepalingen werden verricht als bij de patienten van de huisartsen in groep $A$.

TABEL 5.3 .5

Percentage virologische kweekresultaten in groep B, vergeeld over twee leeftijdsgroepen (virus ondef.", zie tabel 3 )

$\begin{array}{lllllll}\text { kinderen }(N=32) & n & 8 & \text { volwassenen }(N=81) & n & 8 \\ \text { Rotavirus }(n=31) & 4 & 12,9 & \text { Rotavirus }(n=75) & 0 & 0 \\ \text { Entero }(n=31) & 1 & 3,2 & \text { Entero }(n=75) & 1 & 1,3 \\ \text { Adeno }(n=31) & 2 & 6,4 & \text { Adeno }(n=75) & 0 & 0 \\ \text { Virus ondef. } & 0 & 0 & \text { Virus ondef. } & 3 & 3,7\end{array}$

In de groep van 113 patienten, waarbij eveneens een virologisch onderzoek werd verricht kwam rotavirus het meest voor. Het Rotavirus bleek een duidelijke voorkeur te hebben voor kinderen.

Bij de patienten van de huisartsen van groep $B$ werd eveneens nagegaan met welke groep of type bacterieel micro-organisme men te doen had. Tabel 5.3.6 geeft het overzicht, waarbij ook 
nu de faagtypering van de Salmonellae achterwege werd gelaten.

TABEL $5.3 \cdot 6$

Opgave van het voorkomen van de bakteriële micro-organismen naar groepen en typen in groep B.

Groep C S. muenchen

s. bovis morbif.

S. newport

Groep D S. panama

Yersinia enterocolitica type 3

Shigella B. flexneri

Van de Salmonellae in deze groep was typhimurium het meest voorkomende type. In die zin is er sprake van een grote mate van overeenstemming met de typering van de monsters uit de A-groep.

Het makkt kennelijk niet erg veel uit met betrekking tot het voorkomen van de diverse typen Salmonellae, of men te maken heeft met een groep patienten met acute diarree of met een groep met acute of iets langere diarreeklachten. Anders gesteld: tussen altijd kweken of op indikatie. Salmonella typhimurium is klaarblijkelijk het meest voorkomende type Salmonella bij patienten met diarree, althans in dit onderzoek.

Uitgaande van de gepresenteerde getallen met betrekking tot de microbièle kweekresultaten 
is te konstateren dat het percentage positieve kweekresultaten voor zowel de bakteriële als virale agentia bij patienten, waarbij op indikatie een faeceskweek werd verricht (groep B) niet veel verschillend en zeker niet hoger is dan bij patienten waarbij de faeces altijd werd gekweekt (groep A). Kennelijk kan de huisarts geen selektie maken, met als gevolg dat het kweken op indikatie vaak niet meer is dan een willekeurige steekproef.

Het volgende onderwerp is de bespreking van de resultaten van de detektie naar wormeieren en kysten in de faeces van de patienten van de huisartsen van groep $A$ en $B$.

In de onderzoeksprocedure was alleen voor de patienten van de huisartsen van groep A met name kinderen tot en met 10 jaar een onderzoek naar het voorkomen van wormeieren en kysten voorzien (zie hoofdstuk 3) De resultaten van de patienten van huisartsen uit groep A beperken zich dus tot deze leeftijdsgroep.

De reden voor deze beperking is gelegen in de veronderstelling dat als wormen in deze streken een rol spelen bij het veroorzaken van acute diarree, het mede vanwege de faecalorale besmettingsweg zeer vaak personen uit deze leeftijdskategorie betreft.

Van de 182 kinderen in deze leeftijdskategorie in groep $A$ werd van 130 de faeces onderzocht op het voorkomen van wormeieren en kysten. slechts éénmaal werden wormeieren waargenomen. Een erg importante rol zullen de wormeieren gezien dit cijfer niet spelen bij kinderen met acute diarree. Het feit, dat bij slechts 130 kinderen in plaats van 182 een onderzoek naar wormeieren en kysten werd verricht, werd veroorzaakt doordat per abuis op het laboratorium bij een aantal faeces-monsters van kinderen geen onderzoek naar deze organismen werd gedaan. Er is geen reden aan te nemen, dat er sprake is van een systematische fout. Het is dan ook onwaarschijnlijk dat er daardoor een selektie ten aanzien van deze bepaling heeft platsgevonden.

De huisartsen in groep $B$ waren niet gebonden 
aan enigerlei procedures en vroegen bij 85 patienten dit onderzoek naar wormeieren en kysten aan. Opmerkelijk was, dat deze groep van 85 patienten dezelfde verdeling van leeftijd en geslacht vertoonde als er voor de totale groepen A en B kon worden vastgesteld. $B i j$ de kinderen tot en met 10 jaar werd in deze groep $(n=32)$ éénmaal de aanwezigheid van wormeieren vastgesteld en bij de volwassenen (11 jaar en ouder) ( $n=53)$ geen enkele maal. De cijfers met betrekking tot deze bepaling laten aan duidelijkheid niets te wensen over. Bij de klacht acute diarree werden in dit onderzoek zelden wormeieren en kysten aangetroffen in de faeces van de patient.

Vervolgens werd nagegaan wat het voorkomen van de bakteriële en virologische agentia was in de diverse seizoenen. De resultaten zijn uitgezet in de grafieken I en II met de restriktie dat vanwege het geringe voorkomen van resp. Shigella, Yersinia enterocolitica, Adeno- en Enterovirus in beide groepen, deze micro-organismen hierin niet zijn opgenomen. Rotavirus kwam bij patienten van de huisartsen uit groep $A$ in die mate voor, dat opnemen in een grafiek zinvol leek. 
gositieve

I. Groep A: wookkomen Salmonella/Campylobacter per mand kweken

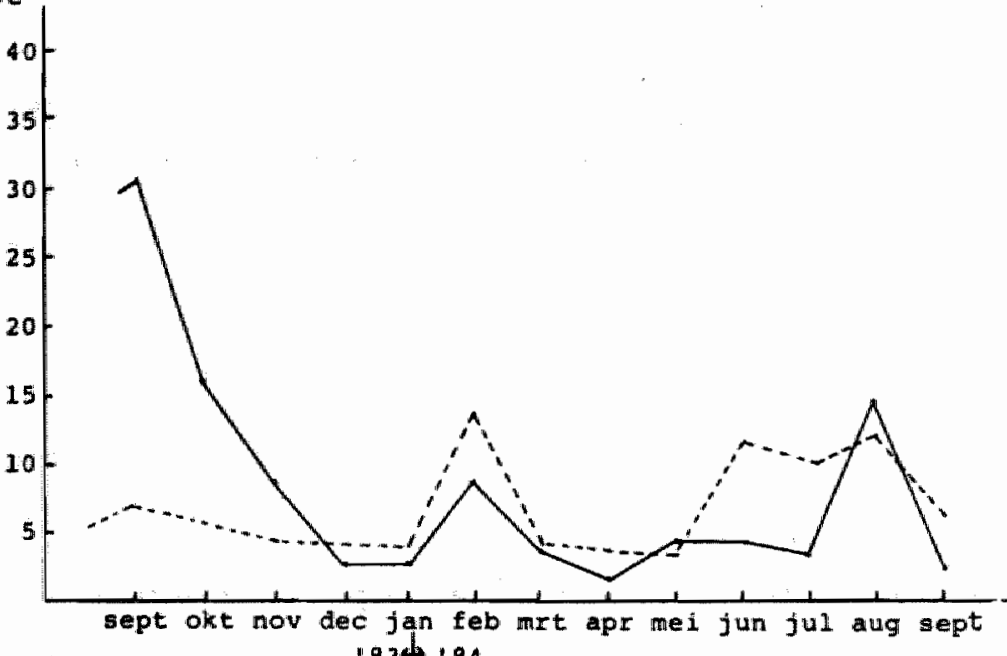
1834.84

- Salmonella $(n=49)$

.... Campylobacter $(n=80)$

II. Groep B Voorkomen Salmonella/Campylobacter per maand - positieve kweken

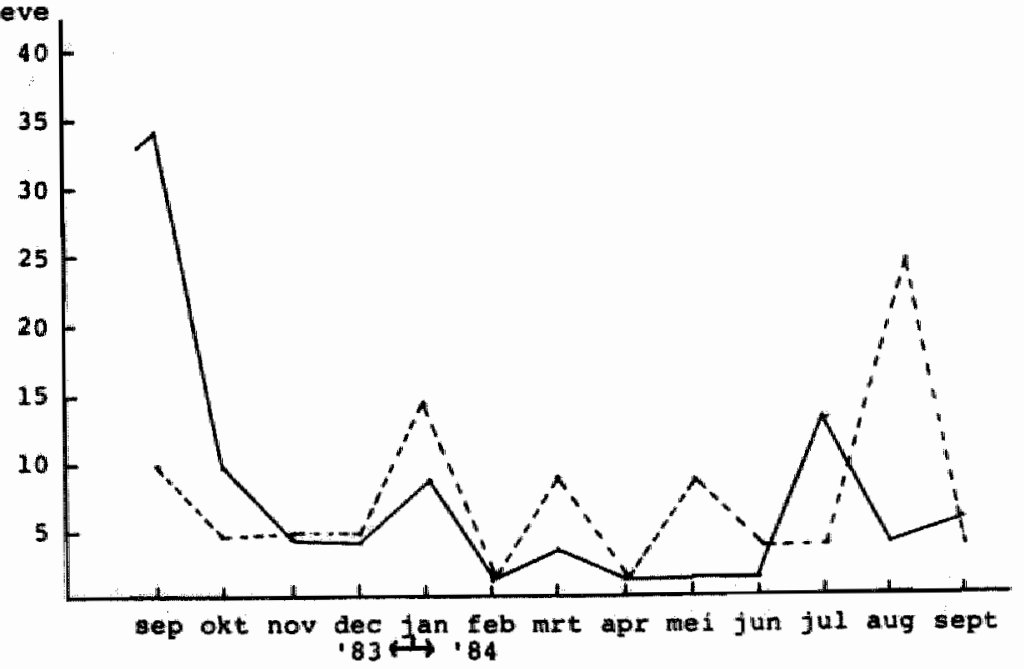

- Salmone11a $(n=20)$

-- Campy lobacter $(\mathrm{n}=20)$ 


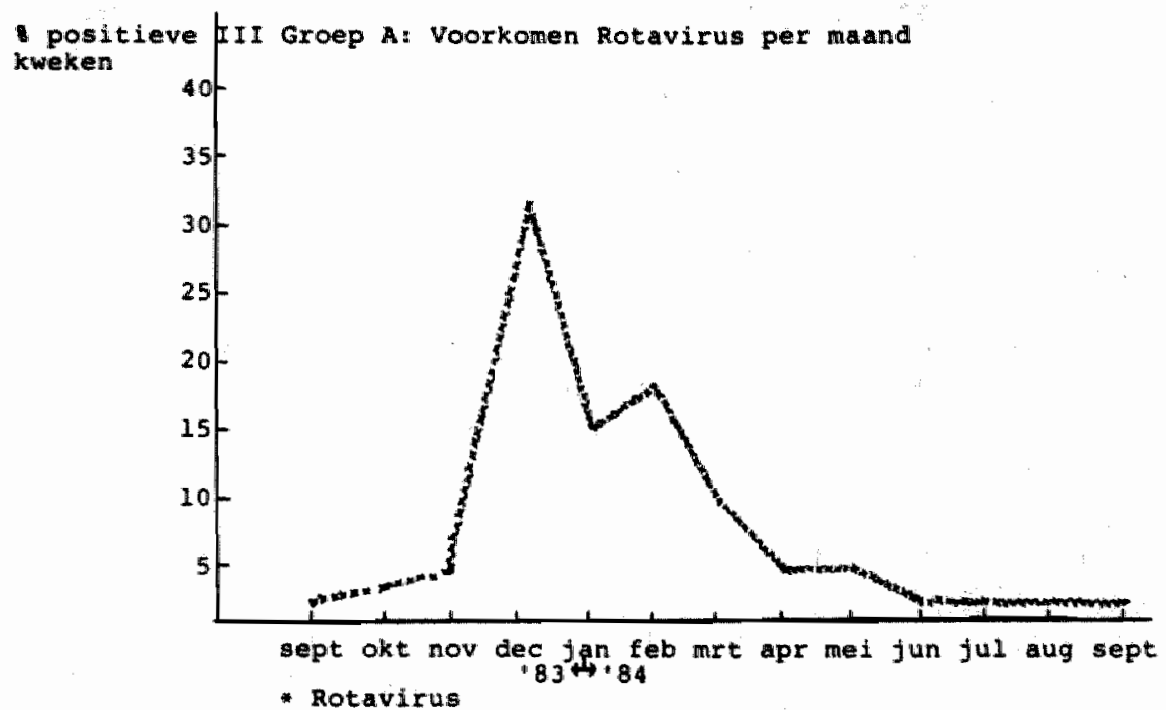

Uit grafieken I en II is af te lezen dat de Salmonellose enige voorkeur hebben voor de zomer en het vroege najaar (1). Toch is daarmee de piek die zowel in grafiek I als in II te zien is in de maand september 1983 niet voldoende verklaard. Door navraag bij de Districts Geneeskundige Dienst en uit cijfers over de laboratoriumaanvragen voor microbiële bepalingen van de huisartsen die niet in dit onderzoek participeerden, kwam naar voren, dat er mogelijk in die maand in 1983 sprake is geweest van een kleine lokale epidemie.

Campylobacter jejuni heeft, indien men de grafieken als richtsnoer neemt, geen duidelijke voorkeur voor een bepaalde tijd van het 
jaar. In de literatuur $(9,10)$ is echter sprake van een seizoentop in de zomer en het vroege najaar, vergelijkbaar met het gedrag van de Salmonellose.

Campylobacteriose komt volgens de gegevens van dit onderzoek bij acute diarree door het gehele jaar voor met een lichte voorkeur voor de zomer. De grafiek over het voorkomen van Campylobacter bij de patienten van huisartsen van groep B (grafiek II) laat zich moeilijker interpreteren. Weliswaar komt Campylobacter in de zomer het meest voor, doch gedurende het gehele jaar zijn afwisselend maanden met wel en geen positieve kweek uitslagen ten aanzien van dit organisme. Bovendien zijn de absolute getallen van dien omvang, dat enige terughoudendheid ten opzichte van de interpretatie geboden is. Dit geldt overigens in deze groep eveneens ten aanzien van de cijfers over het voorkomen van salmonellae.

Het Rotavirus (grafiek III) blijkt bij patienten met acute diarree voorkeur voor de winter te bezitten. Tabel 4 geeft aan dat het bij dit micro-organisme voornamelijk om kinderen gaat.

Van de andere bakteriën c.q. virussen kan van zowel de patienten van de huisartsen in groep A als in groep B gezegd worden, dat hun aantal te gering was om enige uitspraken te doen over het voorkomen in de seizoenen. Wellicht kan een uitzondering gemaakt worden voor het Entero-virus van patienten van de huisartsen in groep $A$.

Van de in totaal 10 gedetekteerde Adenovirussen kwamen er 8 in de maanden augustus en september voor.

5.4. Beloop van de klacht bij patienten van groep B

Tenslotte aandacht voor het beloop van de klacht acute diarree bij de patienten van de huisartsen in groep $B$.

Van de 113 personen, warvan de faeces ook 
virologisch werd onderzocht, werd eveneens een telefonische enquête afgenomen. Iets meer dan $66 \%$ kon op deze manier ook worden bereikt. Tabel 5.4.1 toont de resultaten van de duur van de klacht sinds het kontakt met de huisartspraktijk, verdeeld over twee leeftijdsgroepen, kinderen en volwassenen, gemeten aan de frekwentie.

TABEL $5.4 \cdot 1$

Percentage dagen diarree sinds het kontakt met de huisartspraktijk, verdeeld over twee leeftijdsgroepen in groep $B$

$(\mathrm{N}=75)$

aantal dagen diarree

kinderen $n=21$

19

38,1

19,1

23,8

3-4 dagen

5-7 dagen

$\geqslant 8$ dagen volwassenen

$\mathrm{n}=54$

23,8

Ten opzichte van tabel 4.2 .2 in hoofdstuk 4.2. is het duidelijk, dat zowel kinderen als volwassenen in de B-groep langer diarree houden na het kontakt met de huisartspraktijk dan hun lotgenoten in de A-groep.

Deze konstatering kan echter voor een deel op vertekening berusten, daar groep $B$ een selektie is van patienten met acute diarree, waarbij de huisarts het nuttig of nodig oordeelt een faeceskweek te doen. In die $z$ in is groep $B$ niet te vergelijken met groep $A$.

Het medicijngebruik van de patienten in groep $B$ is lager dan in de A-groep, 66,7 resp. $75,7 \%$. Ook in de B-groep betrof het voornamelijk stopmiddelen. Het aantal positieve kweekuitslagen in deze groep van 75 patienten vertoont dezelfde verdeling als voor de totale B-groep. 
5.5. Nabeschouwing.

In dit hoofdstuk werden de resultaten van het voorkomen van microbiële agentia bij patienten met acute diarree (groep A) getalsmatig vergeleken met een groep patienten met acute of iets langere diarreeklachten (groep B). Ongeacht of de huisarts geindiceerd kweekt bij de klacht diarree (groep B) ofwel "altijd kweekt" (groep A), telkens is er sprake geweest van dezelfde leeftijd- en geslachtsverdeling voor alle bepalingen.

De leeftijd van de patient heeft op zich bij deze groep huisartsen bij de indikatiestelling tot een kweek geen rol gespeeld.

Vóórkomen.

Ten aanzien van het vóórkomen van de Salmonellae kan worden gesteld, dat zowel bij patienten van de huisartsen van groep $A$ als van groep $B$ percentueel vrijwel hetzelfde aantal micro-organismen bij kinderen en volwassenen wordt gekweekt.

Salmonellae worden overigens bij patienten van huisartsen uit beide groepen vaker bij kinderen dan bij volwassenen gekweekt.

Met het voorkomen van Campylobacter jejuni is het anders gesteld. Ten eerste komt Campylobacter jejuni ten opzichte van salmonellae vaker voor bij patienten met acute diarree, dan bij patienten bij wie alleen op indikatie wordt gekweekt en die acute of iets langere diarreeklachten hebben.

Ten tweede komt Campylobacter jejuni in tegenstelling tot de Salmonellae bij patienten van huisartsen uit beide groepen vaker voor bij volwassenen dan bij kinderen. Gebaseerd op deze gegevens, zou men kunnen stellen, dat de huisarts door bij de klacht acute diarree op indikatie te kweken een niet onaanzienlijk percentage Campylobacter jejuni niet ontdekt.

Yersinia enterocolitica kwam in dit onderzoek bij alle patienten in zeer geringe mate voor. 
op grond van dit gegeven lijkt het overbodig dit micro-organisme routine-matig bij acute diarree te kweken. Dit is des te meer van belang, daar een belangrijk deel van dit toch al zelden voorkomend organisme vaak pas met behulp van de techniek van de koude ophoping wordt ontdekt (11). Deze techniek vergt nog eens een aantal extra dagen en tegen deze achtergrond zou de warde van een dergelijke bepaling in relatie met het beleid van de huisarts wel eens gering kunnen zijn.

Shigellae behoren kennelijk eveneens tot die micro-organismen die weinig voorkomen in de faeces van patienten met diarree. Er werd geen verschil gevonden in het voorkomen bij patienten van huisartsen van groep $A$ en $B$. Niettemin is het bekend $(4,12)$, dat er van dit micro-organisme maar een zeer gering aantal aanwezig behoeft te zijn om een infektie te veroorzaken in tegenstelling tot de andere hierboven genoemde micro-organismen.

Uit de resultaten is verder af te lezen dat Salm.typhimurium zonder meer het meest voorkomende type is bij patienten met een Salmonellose in dit onderzoek. Dit gegeven is geheel in overeenstemming met de landelijke cjfers (12).

Het onderzoek naar het voorkomen van virussen bij patienten met diarree leverde voor zowel de patienten van huisartsen van de A-groep als van groep B, maar 3 verschillende virussen op. De verwachting bij de onderzoeker, zeker in de groep patienten met acute diarree, een groter aantal virussen te zullen detekteren, kon niet worden bevestigd. Uit het voorkomen van precies dezelfde virussen bij patienten van huisartsen van beide groepen $A$ en $B$ zou men kunnen konkluderen, dat er kennelijk in deze regio (regio Heuvelland, zuidelijk zuid-Limburg) geen andere typen bij deze klacht voorkomen, althans in een frekwentie die epidemiologisch van belang is. 
over het voorkomen van wormeieren en kysten bij patienten met diarree in dit onderzoek kan men kort zijn: zij spelen geen rol.

\section{Seizoen.}

Salmonellose en Campylobacteriose komen voornamelijk voor in de zomer en in het vroege voorjaar, alhoewel dit gedrag het meest uitgesproken is voor de Salmonellae. In dit onderzoek was er geen duidelijke seizoensgebondenheid te konstateren m.b.t. de Campylobacter jejuni.

$B i j$ de virussen bleek het Rotavirus behoudens een voorkeur voor kinderen ook bij uitstek in het winterseizoen voor te komen. Men kan stellen dat, indien er in de winter sprake is van het vermoeden op een infektieuze diarree bij kinderen, een virale verwekker (Rotavirus) in overweging genomen moet worden.

Aan het einde van deze presentatie over het voorkomen van micro-organismen bij patienten met acute of iets langer durende diarree, kan men zich afvragen, wat de konsekwenties voor het handelen van de huisarts zijn?

In het algemeen kan men stellen dat er in de behandeling door huisartsen van de infektieuze diarree geen wezenlijk verschil bestaat. Weliswaar lijkt Campylobacter frekwenter voor te komen dan de Salmonellae, maar dit leidt niet tot specifieke handelingen van de huisarts.

Bij de Yersiniose kan de aandacht van de huisarts in het bijzonder verlangd worden. Een infektie met dit micro-organisme kan een sterk op appendicitis gelijkend beeld vertonen. In deze situatie kan een positief kweekresultaat onnodige laparotomieën voorkomen.

Brononderzoek bij Shigellose is sterk aan te bevelen en in die zin is het aanvragen van een faeceskweek door de huisarts een belangrijke stap, vooral bij patienten met diarree afkomstig uit besloten gemeenschappen. 
Van belang voor het handelen van de huisarts is het onderbreken van de infektieketen, alhoewel dit voor de behandeling van de klacht van geen invloed is. In die zin is brononderzoek zinnig. $\mathrm{Nu}$ is de virale infektieketen in tegenstelling tot de bakteriële veel minder duidelijk en derhalve ook minder goed te doorbreken. Uitgaande van de onderzoeksgegevens bleek, dat virussen bij acute diarree een gelimiteerde rol spelen. Het beleid a priori afstemmen op een virale verwekker, hetgeen nog eens in de hand wordt gewerkt door de terminologie buikgriep, is niet terecht.

Ten aanzien van het beloop van de klacht bij een positieve kweekuitslag na de interventie van de huisarts is een vergelijking tussen patienten van $A$ en $B$ mar in beperkte zin mogelijk. Bij de patienten van groep $B$ waraij via de telefonische enquête vragen over het beloop van de klacht konden worden gesteld, werd maar een gering aantal positieve kweekresultaten gekonstateerd (zie bijlage IV). Met in acht neming van deze restriktie kan worden vermeld, dat 13,28 van de patienten met een positieve bacteriële kweekuitslag $(n=106)$ uit de A-groep 8 dagen of meer diarree hebben na het kontakt met de huisarts, terwijl dit percentage voor de B-groep-patienten met een positieve bacteriële kweekuitslag $(n=12) \quad 25 \%$ bedraagt. In groep A heeft ruim $80 \%$ van de patienten met een positieve kweekuitslag na 5 dagen geen diarree meer. In groep $B$ gaat het om ruim 60\%. Het verschil in de duur van de diarree-klacht tussen patienten met een positieve kweekuitslag uit groep $A$ en $B$ heeft waarschijnlijk niets te maken met de kweekaanvraag (standaard versus indikatie). In wezen werden met uitzondering van Yersinia enterocolitica, dat in de B-groep in 71,48 werd aangevraagd, alle andere micro-organismen vrijwel altijd aangevraagd bij zowel de patienten van groep A als B. Daarmee is de vraag aan de orde wanneer en in welke omstandigheden het kweken van de faeces door de huisarts in het kader van het behandelingsplan zinvol is. Het kweken 
van de faeces bij acute diarree kan om de volgende reden van belang zijn:

1. in het kader van de diagnostiek

2. met het oog op besmettingsgevaar

3. eventueel ter verkrijging van epidemiologische gegevens.

ad 1: Voor de individuele patient speelt vooral de duur van de klacht een belangrijke rol bij de overweging te kweken. Immers, indien er sprake is van een infektieuze diarree met komplikaties (septisch beeld) zal in eerste instantie een breedspectrum antibioticum overwogen worden, omdat het kweekresultaat pas na 4 à 5 dagen bekend zal zijn. Daarbij komt dat het behandelingsplan in de zin van dieetadvies, herstel van de vochtbalans, symptomatische therapie, niet beinvloed wordt door de aanwezigheid van een micro-organisme.

In geval van een diarree, die langer dan 10 dagen aanhoudt en niet of onvoldoende reageert op dieet en/of medikatie is een faeceskweek geindiceerd. In deze situatie is er sprake van een ongewenst beloop, waarbij een grondig onderzoek inklusief een faeceskweek als onderdeel van een laboratoriumonderzoek sterk aan te bevelen is. Een minder duidelijke reden tot kweken bij de individuele patient is het voorkomen van koorts (zie 6.2.1; odds ratio kinderen resp. volwassenen is 3,0 en 6,9 m.b.t. de bakteriële kweekuitslag en 3,0 en 2,2 m.b.t. virologische kweekuitslag) en bloed (odds ratio kinderen resp. volwassenen is 10,7 en 1,7 m.b.t. de bakteriële kweekuitslag en 0,9 en 0,6 m.b.t. virologische kweekuitslag) bij de ontlasting. In het algemeen kan worden gesteld dat indien de individuele huisarts bij een incidentele patient om welke reden dan ook overweegt de faeces te kweken, de aanwezigheid van koorts en bloed bij de ontlasting als doorslagge- 
vende faktor kan worden beschouwd. ook het volgende gegeven is in het kader van de diagnose van belang:

In de anamnese wordt een recent verblijf van de patient in de (sub)tropen of Zuid-Europa naar voren gebracht.

In een dergelijke situatie is er zowel voor de patient als voor diens omgeving sprake van een verhoogde besmettingskans, met bovendien micro-organismen die in onze streken sporadisch voorkomen.

In dit geval zou gekweekt moeten worden op Salmonella, Shigella, Campylobacter fetus ssp jejuni, Yersinia enterocolitica, Giardia Lamblia en Entamoeba histolytica (verse faeces).

ad 2: De volgende omstandigheden zijn in verband met besmettingsgevaar een reden tot het kweken van de faeces bij acute diarree:

- Patienten met een risikoberoep met name verpleging, verzorging. Deze personen kunnen een transmissie van micro-organismen teweeg brengen op patienten respektievelijk bewoners van de instelling waar zij werken.

- Patienten werkzaam in de open levensmiddelenbranche.

- Patienten verblijvend in bijzondere woonomstandigheden: tehuizen, inrichtingen.

- Uitbreiding van de klacht bij twee of meer personen in één gezin.

De kweekaanvraag in deze situaties zou moeten bestaan uit een onderzoek naar de a anwezigheid van Salmonella, Shigella, Campylobacter fetus ssp jejuni, Giardia Lamblia. Virale agentia zijn in dit kader van minder importantie.

ad 3: Uit het oogpunt van de epidemiologie kan worden gesteld, dat de huisartspraktijk in dit onderzoek zich ontwikkeld heeft tot een goed peilstation. Immers de kweekresultaten van de patienten van de 
huisartsen uit groep B (op indikatie) geven een redelijk beeld van het voorkomen van de diverse micro-organismen, maar er is wellicht toch sprake van enige vertekening door het beperkte aantal deelnemers. Altijd echter kweken bij elke acute diarree is alleen al uit kostenoogpunt af te wijzen en uitgaande van de onderzoeksgegevens (groep A) werden geen nieuwe gegevens verkregen ten aanzien van het voorkomen van microbièle agentia bij acute diarree.

Men kan zich een situatie voorstellen dat ten aanzien van de informatie over het voorkomen van microbiële verwekkers in een bepaald gebied volstaan zou kunnen worden met een survey die per toerbeurt in een aantal huisartspraktijken in een dergelijke regio verricht zou worden. Op deze wijze zou met minimale kosten door de huisarts aan de epidemiologie van gastro-enteritis een bijdrage geleverd kunnen worden. Voor de huisarts zou een kontinue informatiebron specifiek gericht op zijn eigen regio in casu eigen werkterrein ter beschikking staan. De bovengenoemde ontwikkeling is voor een aantal medische problemen in bepaalde gebieden van Nederland reeds in gang gezet. Een verdere uitbreiding is sterk te overwegen. 
HOOFDSTUK 6 : HET ANALYSE-MODEL

6.1. Inleiding

Patienten die vanwege diarree de huisarts raadplegen doen dit niet alleen omdat zij zich ziek voelen, een begeleidend symptoom hen zorgen baart of omdat zij de oorzaak van de klacht willen weten, maar zij doen dit zeker ook omdat er middelen tegen diarree bestaan. Acute diarree, gelet op dit karakter, kan vergeleken worden met een andere aandoening uit de rij van "minor ailments": de gewone verkoudheid. Zoals een verkoudheid bij sommige patienten (risiko-patienten) in een klein percentage ernstige komplikaties kan veroorzaken, bijvoorbeeld (broncho pneumonie), zo kan acute diarree in een beperkt aantal gevallen eveneens tot ernstige problemen aanleiding geven. Bekend zijn het uitdrogingsgevaar bij het jonge kind en de grote risiko's voor de volksgezondheid bij bijvoorbeeld een shigella-epidemie $(1,2)$.

op grond van zijn opleiding, die voornamelijk intramuraal heeft plaatsgevonden, is de (huis)arts gewend het onderzoek naar de oorzaken van de klacht acute diarree te baseren op klinische gegevens. Aan de hand van op deze gegevens gefundeerde anamnestische vragen en eventueel na lichamelijk onderzoek zal de huisarts trachten een schatting te maken van de ernst van de klacht en de oorzaak, en daaraan gekoppeld de noodzakelijke matregelen nemen ter behandeling en voorkoming van uitbreiding. Men kan zich afvragen of hetgeen geleerd is in een klinische setting wel toepasbaar is in de situatie waarin deze klacht zich bij uitstek afspeelt, namelijk buiten de kliniek en indien hulp wordt ingeroepen aan het eerste loket van de gezondheidszorg: de huisartspraktijk.

Toegespitst op het vóórkomen van microbiële verwekkers bij deze klacht, zou de vraag ook kunnen luiden: wat is in de huisartspraktijk 
de samenhang van de klacht acute diarree en het voorkomen van de diverse micro-organismen? of nog anders gezegd: kan de huisarts met behulp van de anamnese enige voorspellende uitspraken doen ten aanzien van de aanwezigheid en de aard van micro-organismen? Bij het stellen van de diagnose baseert de huisarts zich zeker bij deze klacht vrijwel uitsluitend op de anamnese en het lichamelijk onderzoek. Andere hulpmiddelen zoals laboratorium worden in eerste instantie niet aangewend.

In feite liggen twee vraagstukken ter bestudering voor:

1. Is de anamnese (of onderdelen ervan) een geschikt instrument om uitspraken te doen over de samenhang van de klacht acute diarree en de aanwezigheid van een bepaald micro-organisme? Met het antwoord op deze vraag zou tevens vraagstelling 4 behandeld zijn.

2. Kan mede op basis van een mogelijke samenhang tussen anamnestische kenmerken en een kweekuitslag een indikatieschema opgesteld worden ten aanzien van het gewenste handelen van de huisarts bij de klacht acute diarree?

6.2. Het analyse-model (bijlagen XIV,XV,XVI,XVII)

In het hierna volgende analysemodel zijn de anamnestische kenmerken als een test (de onafhankelijke variabele) ten aanzien van de kweekuitslag (de afhankelijke variabele) gehanteerd, analoog aan de situatie van een laboratoriumtest en een ziektestatus.

Nagegaan is welke samenhang er tussen deze onafhankelijke variabele (de test) en de kweekuitslag (de afhankelijke variabele) bestond m.b.v. de likelihood ratio en de odds ratio. Vervolgens is nagegaan in hoeverre deze onafhankelijke variabelen in onderlinge samenhang (de test) een voorspellende waarde beza- 
ten ten aanzien van de kweekuitslag (afhankelijke variabele) via een lineaire stapsgewijze regressie.

De volgende kenmerken werden als een test beschouwd:

- duur van de klacht vóór het kontakt van de patient met de huisartspraktijk

- defaecatiefrekwentie

- konsistentie

- kleur

- bloedbijmenging

- slijmbijmenging

- braken

- koorts

- buikpijn

- "erge" hoofdpijn (zie ook hoofdstuk 4.1)

- ziektegevoel

- vakantie/buitenlandse reis

- leeftijd (verdeling in twee groepen: kinderen tot en met 10 jaar en volwassenen van 11 jaar en ouder).

De likelihoodratio (aannemelijkheidsquotiënt = $L R$ ) is het quotiënt van de kans (P), dat een bepaald symptoom of een bepaalde testuitslag (T) voorkomt bij personen die een bepaalde ziekte hebben (D) en de overeenkomstige kans bij personen die deze ziekte niet hebben. Men kan haar voor positieve respektievelijk negatieve uitslagen noteren als (3):

$$
\begin{aligned}
& \mathrm{LRt}=\frac{\mathrm{P}(\mathrm{T}+/ \mathrm{D}+)}{\mathrm{P}(\mathrm{T}+/ \mathrm{D}-)} \text { ofwel } \frac{\text { sensitiviteit }}{\text { l008-specificiteit }} \\
& \mathrm{LR}-=\frac{\mathrm{P}(\mathrm{T}-/ \mathrm{D}+)}{\mathrm{P}(\mathrm{T}-/ \mathrm{D}-)} \text { ofwel } \frac{100 \text {-sensitiviteit }}{\text { specificiteit }}
\end{aligned}
$$

Uit de definitie en de formules is direkt af te leiden dat een likelihood ratio van 1.0 betekent, dat de test waardeloos is, c.q. geen onderscheidend vermogen heeft. Hoe meer de LR van 1.0 afwijkt (variërend van 0.0 tot oneindig), des te beter is het onderscheidend vermogen.

Het is aantrekkelijk om een samenvattende maat voor het onderscheidend vermogen te hebben, 
uitgaande van sensitiviteit en specificiteit. Toch blijkt dat er nog sprake is van twee maten, namelijk LRt en LR-. Dit kan worden opgelost door als samenvattende mat te kiezen voor het quotiënt van LRt en LR-. Dit is de zogenaamde odds ratio (OR), die met name in de etiologische epidemiologie gebruikt wordt. In dit geval kan men haar als volgt definiëren:

\section{OR $=\frac{\text { terecht positieven }}{\text { fout negatieven }} / \frac{\text { fout positieven }}{\text { terecht negatieven }}$ \\ $=\frac{\text { sensitiviteit }}{\text { I008-sensitiviteit }} \times \frac{\text { specificiteit }}{\text { 1008-specific. }}=\frac{L R+}{\text { LR- }}$}

De OR is gelijk aan 1.0 als het diagnostikum geen onderscheidend vermogen heeft en wijkt hiervan sterker af, naarmate het onderscheidend vermogen beter is. Bij een positief verband tussen testuitslag en aandoening is de odds-ratio groter dan 1,0 en bij een negatief verband neemt $z i j$ de waarden tussen 1,0 en 0,0 aan $(4,5)$.

\subsubsection{Likelihood ratio en odds ratio}

Uit het onderzoeksmateriaal (groep A, zie hoofdstuk 3.2) zijn de patienten met een positieve kweekuitslag en de patienten met een negatieve kweekuitslag geselekteerd.

Door middel van kruistabellen is gezocht naar de samenhang van de klacht in dit geval de anamnestische kenmerken (de test) en de kweekuitslag bij deze patienten. Uit deze test versus kweekuitslag is de samenhang berekend door middel van odd's ratio's met de daarbij behorenfe

betrouwbaarheids-intervallen (B.I.V."). Tevens zijn de sensitiviteit en de specificiteit aangegeven (zie bijlage XIV).

Tabellen 1 tot en met 10 tonen de resultaten van die kenmerken, waarvan een zodanige samenhang met de kweekuitslag kon worden vastgesteld, dat op grond daarvan geschikte bouwstenen voor een indikatieschema zouden kunnen worden geleverd. De tabellen geven de resulta- 
ten weer met betrekking tot het verband tussen deze kenmerken en een positieve bakteriële respektievelijk virale kweekuitslag. Deze uitslagen zijn niet verder onderverdeeld naar subtypen. Wel is er, op klinische gronden, telkens een aparte analyse verricht voor kinderen en volwassenen. Voor de resultaten met betrekking tot de kweekuitslagen van de afzonderlijke micro-organismen en de anamnestische kenmerken wordt verwezen naar bijlagen XIV , XV, XVI, XVII.

In iedere tabel is vergeleken de verdeling van het anamnestisch gegeven bij personen met een positieve kweekuitslag en bij personen die noch een positieve bakteriële noch een positieve virale kweekuitslag hadden.

TABEL $6.2 \cdot 1.1$

Kruistabel anamnestisch kenmerk: "frekwentie" versus totale bakteriële kweekuitslag, verdeeld over twee leeftijdskategoriën

kinderen

$\mathrm{N}=117$ volwassenen

$\mathrm{N}=308$ bakt.

kweek-

uitslagen

$+\quad-$ bakt.

kweek-

uitslagen

$+\quad-$

frekw.hoog

( 6 dd.) $20 \quad 26 \quad 46$ hoog $46 \quad 130 \quad 176$

laag

$\begin{array}{llllllll}(3-5 d d) & 10 & 61 & 71 & \text { laag } & 30 & 102 & 132\end{array}$

$\begin{array}{llllllll}\text { totaal } & 30 & 87 & 117 & \text { totaal } & 76 & 232 & 308\end{array}$

Odds ratio $=4,7$

$B \cdot I \cdot V \cdot=2,0-11,0$

sensitiviteit $=66,7 \%$

spẹcificiteit $=70,1 \%$

$\mathrm{LR}=2,2$
Odds ratio $=1,2$

B. I.V. $=0,6-2,0$

sensitiviteit $=60,5 \%$

specificiteit $=44,0 \%$ $\mathrm{LR}^{+}=1,1$ 
TABEL $6.2 \cdot 1.2$

Kruistabel anamnestisch kenmerk: "frekwentie" versus totale virologische kweekuitslag, verdeeld over twee leeftijdsgroepen

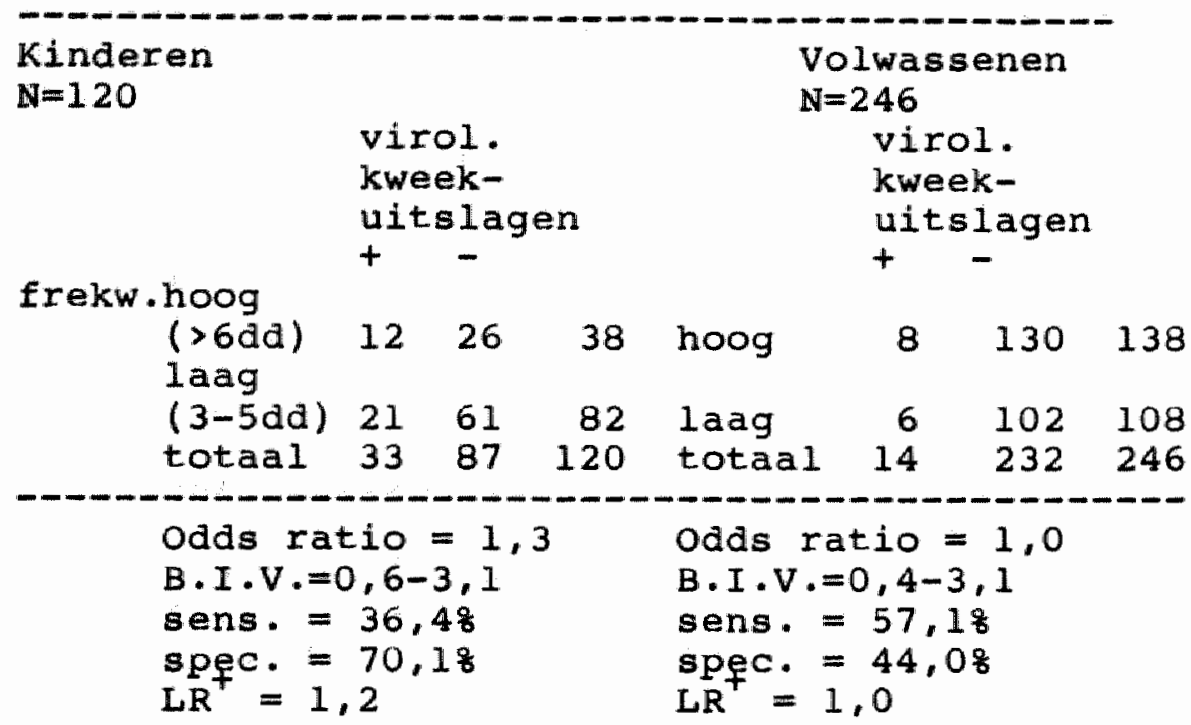

In de kindergroep bestaat er voor wat het bakterielle kweekresultaat betreft een grotere kans op een positieve uitslag, wanneer er sprake is van een hoge defaecatiefrekwentie. Deze relatie is niet terug te vinden bij volwassenen, m.b.t. de bakteriële kweekuitslag en ook niet aanwezig bij de totale patientengroep t.a.v. de virologische kweekresultaten. 
TABEL $6 \cdot 2 \cdot 1 \cdot 3$

Kruistabel anamnestisch kenmerk: "bloed" bij de ontlasting versus de totale bakteriële kweekuitslag, verdeeld over twee leeftijdskategorieën

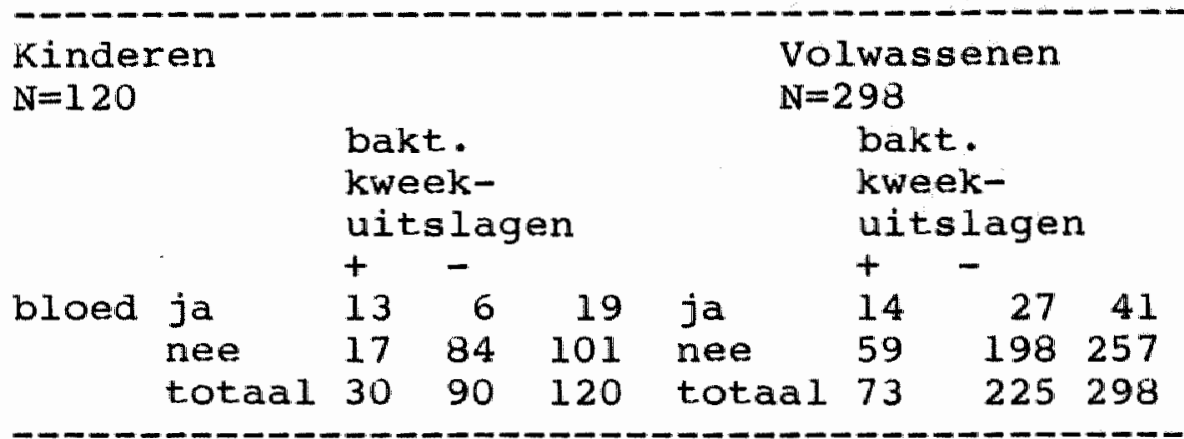

Odds ratio $=10,7$ Odds ratio $=1,7$

$\mathrm{B} \cdot \mathrm{I} \cdot \mathrm{V} \cdot=4,0-28,5 \quad \mathrm{~B} \cdot \mathrm{I} \cdot \mathrm{V} \cdot=0,9-3,3$

sens. $=43,38$

sens. $=19,28$

spec. $=93,3 \%$

specc. $=88,08$

$\mathrm{LR}=6,5$

$\mathrm{LR}^{+}=1,6$

TABEL $6 \cdot 2 \cdot 1 \cdot 4$

Kruistabel anamnestisch kenmerk: "bloed" bij de ontlasting versus de totale virologische uitslag, verdeeld over twee leeftijdsgroepen

Kinderen

$\mathrm{N}=123$
Volwassenen $N=239$

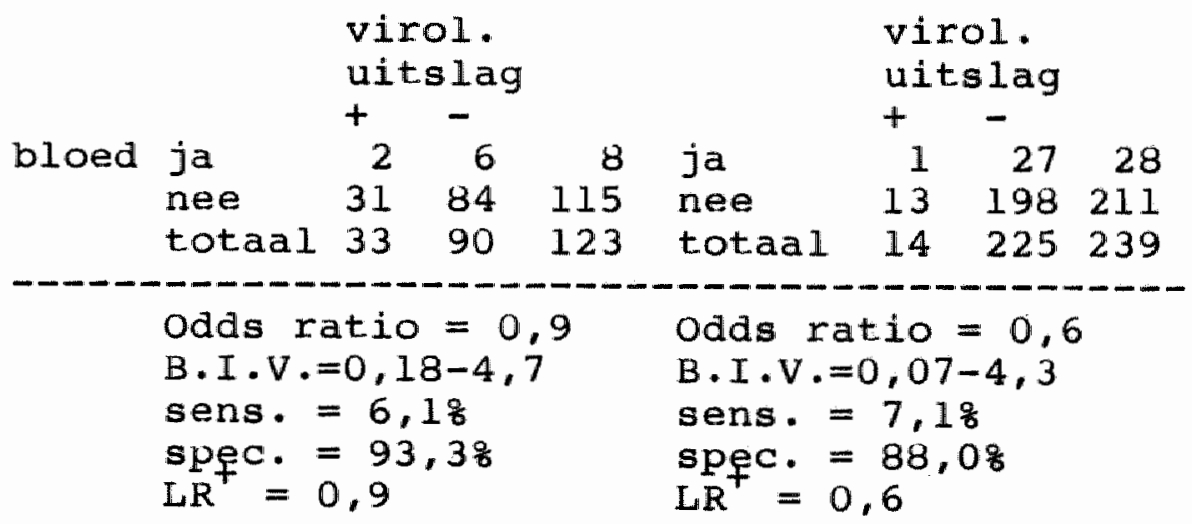

Bloed in de anamnese bij kinderen met acute 
diarree lijkt perspektieven te bieden m.b.t. de meer-kans met een positieve bakteriële kweekuitslag te doen te hebben. Een bevinding die bij volwassenen niet is terug te vinden. Dit laatste geldt eveneens voor de totale patientengroep met betrekking tot de virologische kweekuitslag.

TABEL $6.2 \cdot 1.5$

Kruistabel anamnestisch kenmerk: "slijm" bij de ontlasting versus de totale bakteriologische kweekuitslag, verdeeld over twee leeftijdsgroepen.

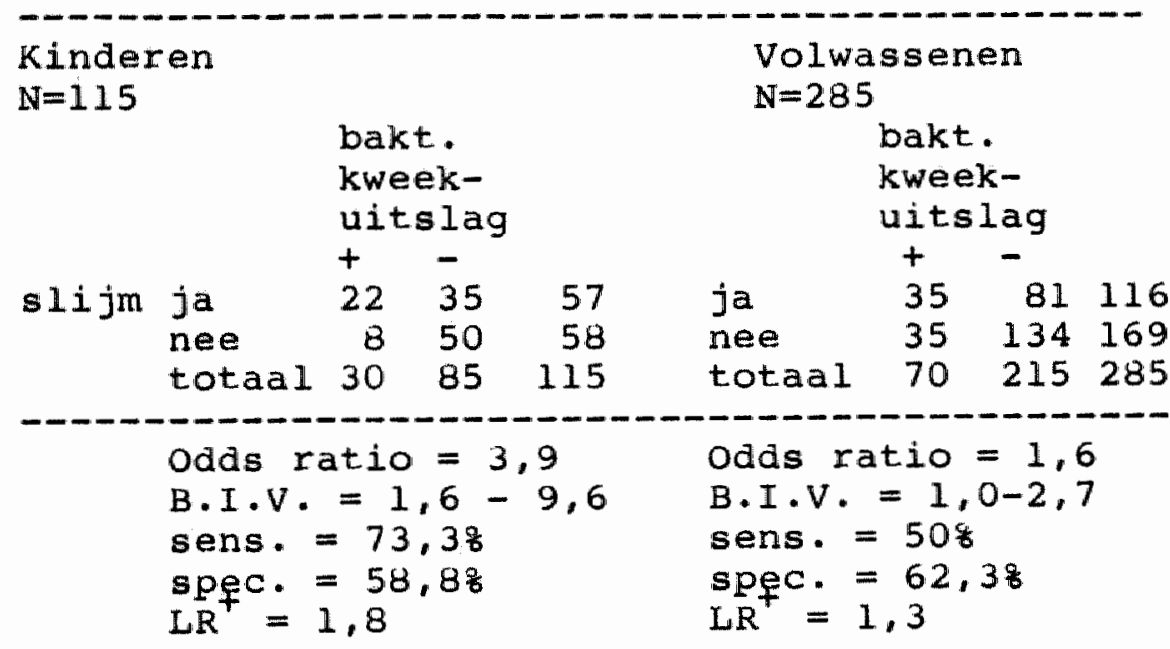

TABEL 6.2 .1 .6

Kruistabel anamnestisch kenmerk: "slijm" bij de ontlasting versus de totale virologische uitslag, verdeeld over twee leeftijdsgroepen.

\begin{tabular}{|c|c|c|c|c|c|c|c|c|}
\hline \multirow{3}{*}{\multicolumn{2}{|c|}{$\begin{array}{l}\text { Kinderen } \\
\mathrm{N}=118\end{array}$}} & \multicolumn{7}{|c|}{$\begin{array}{l}\text { Volwassenen } \\
\mathbb{N}=227\end{array}$} \\
\hline & & \multicolumn{3}{|c|}{ virol.uitslag } & & \multicolumn{3}{|c|}{ virol.uitsla } \\
\hline & & + & - & & & + & - & \\
\hline $\mathrm{Li}$ & $\begin{array}{l}\text { ja } \\
\text { nee }\end{array}$ & $\begin{array}{l}20 \\
13 \\
33\end{array}$ & $\begin{array}{l}35 \\
50 \\
85\end{array}$ & $\begin{array}{l}55 \\
63\end{array}$ & $\begin{array}{l}\text { ja } \\
\text { nee } \\
\text { totaal }\end{array}$ & $\begin{array}{r}6 \\
6 \\
12\end{array}$ & $\begin{array}{r}81 \\
134 \\
215\end{array}$ & \\
\hline
\end{tabular}

odds ratio $=2,2$

Odds ratio $=1,6$

B.I.V. $=1,0-5,0$

B.I.V. $=0,5-5,3$ 


$$
\begin{aligned}
& \text { sens. }=60,68 \\
& \text { spec. }=58,88 \\
& L R=1,5
\end{aligned}
$$

$$
\begin{aligned}
& \text { sens. }=50,58 \\
& \text { spec. }=62,38 \\
& L R=1,3
\end{aligned}
$$

Kinderen met acute diarree met slijm bij de faeces hebben een grotere kans op een positief bakteriologisch kweekresultaat. De relatie is evenwel niet zo sterk als bij het kenmerk bloed. Bij volwassenen is er nauwelijks sprake van een verhoogde kans. Slijm en het voorkomen van de positieve virologische kweekuitslag hebben wel enige relatie met elkaar. Dat wil zeggen, in de kindergroep is er een zekere samenhang, bij de volwassenen nauwelijks.

TABEL 6.2 .1 .7

Kruistabel anamnestisch kenmerk: "koorts" bij de klacht acute diarree versus de totale bakteriologische kweekuitslag, verdeeld over twee leeftijdsgroepen

Kinderen

$\mathrm{N}=120$

koorts ja bakt.

kweek-

uitslagen

bakt.
kweek-
uitslagen
$+\quad-$

$19 \quad 33$

$11 \quad 57$

nee

totaal 30
Volwassenen

$\mathrm{N}=300$

bakt.

kweek-

uitslagen

$+$

58

$84 \quad 142$

68 nee

16

142158

226300

$\begin{array}{ll}\text { Odds ratio }=3,0 & \text { odds ratio }=6,1 \\ \text { B.I.V. }=1,3-6,9 & \text { B.I.V. }=3,4-10,9 \\ \text { sens. }=63,38 & \text { sens. }=78,48 \\ \text { spec. }=63,38 & \text { spec. }=62,88 \\ \text { LR }=1,7 & \text { LR }=2,1\end{array}$


TABEL $6.2 \cdot 1.8$

Kruistabel anamnestisch kenmerk: "koorts" bij de klacht acute diarree versus de totale virologische uitslag, verdeeld over twee leeftijasgroepen.

Kinderen

$\mathrm{N}=123$

\begin{tabular}{lll} 
& \multicolumn{3}{c}{ virol.uits } \\
koorts ja & 21 & - \\
nee & 12 & 57 \\
totaal & 33 & 90 \\
\hline Odds ratio & $=3,0$ \\
B.I.V. $=1,3-6,8$ \\
sens. $=63,68$ \\
spec. $=63,38$ \\
LR $=1,7$
\end{tabular}

\section{Volwassenen}

$\mathrm{N}=240$

virol.uitslag

$$
+
$$

$54 \mathrm{ja}$

69 nee $6 \quad 142 \quad 148$

84

92

123 totaal $14 \quad 226 \quad 240$

De aanwezigheid van koorts in de anamnese geeft een grotere kans op zowel een positief bakteriëel als virologisch kweekresultaat voor alle patienten. In dit onderzoek werd aan de patient (c.q. ouders of verzorgenden) de vraag gesteld of er sprake was van koorts c.q. een koortsig gevoel bij de klacht acute diarree. Het antwoord op deze vraag werd aangegeven bij het kenmerk koorts. Het bevestigen of ontkennen van het bestaan van koorts door de patient geeft echter geen informatie over de temperatuur. Antwoorden op de vraag wat de temperatuur in graden, indien gemeten, was, werden ondergebracht bij het kenmerk temperatuur (zie bijlage VI). 
TABEL $6 \cdot 2 \cdot 1 \cdot 9$

Kruistabel anamnestisch kenmerk: "erge hoofdpijn" bij de klacht acute diarree versus de totale bakteriële kweekuitslag, verdeeld over twee leeftijdsgroepen

Kinderen

$\mathrm{N}=78$

\begin{tabular}{llll} 
& $\begin{array}{l}\text { bakt. } \\
\text { kweek- } \\
\text { uitslagen } \\
+\end{array}$ & - \\
"erge" ja & 3 & 6 \\
hoofd- nee 14 & 55 & 69 \\
pijn & totaal 17 & 61 & 78 \\
\hline & Odds ratio $=2,0$ \\
B.I.V. $=0,4-8,7$ \\
sens. $=17,68$ \\
spec. $=90,28$ \\
LR $=1,8$
\end{tabular}

Volwassenen

$\mathrm{N}=266$

bakt. kweekuitslagen $+$

ja nee 36 $63 \quad 99$ $141 \quad 167$ totaal $62 \quad 204266$

\section{TABEL $6 \cdot 2 \cdot 1 \cdot 10$}

Kruistabel anamnestisch kenmerk: "erge hoofdpijn" bij de klacht acute diarree versus de totale virologische uitslag, verdeeld over twee leeftijdsgroepen

Kinderen

$\mathrm{N}=87$

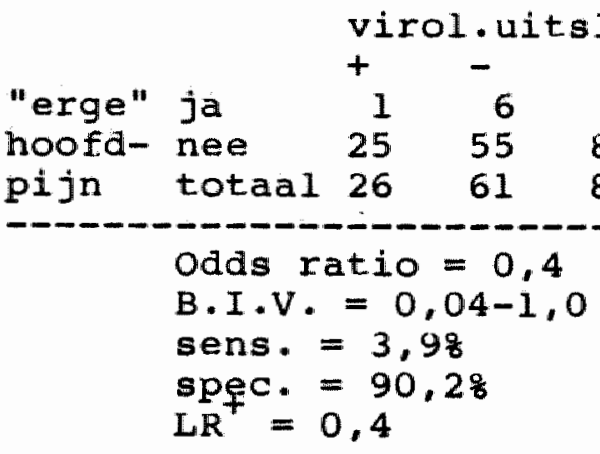

Volwassenen $\mathrm{N}=217$

Odds ratio $=3,1$ B.I.V. $=1,7-5,5$ sens. $=58,18$ spec. $=69,18$ $\mathrm{LR}^{+}=1,9$ 
De relatie tussen "erge hoofdpijn" en microbiële oorzaken moet voor dit kenmerk gezocht worden bij de volwassenen met een positieve bakteriële kweekuitslag.

De bovengenoemde anamnestische kenmerken hebben een zeer wisselende samenhang met de kweekresultaten. Vooral de defaecatiefrekwentie, bloed en slijm spelen bij kinderen t.a.v. de bakteriële kweekuitslag een belangrijke rol. Koorts blijkt bij alle patienten een grotere kans te bieden op een positief kweekresultaat, zij het dat dit duidelijker is voor een bakterieel dan een virologisch kweekresultaat. De volgende stap in het onderzoek zal moeten leiden tot een inzicht in hoe sterk de samenhang tussen deze kenmerken en de positieve kweekuitslag is, wanneer zij tegelijkertijd in de analyse worden gebracht. De vraag daarbij is dus, of er op grond van een bepaalde kombinatie van anamnestische gegevens een hogere voorspellende waarde bereikt wordt dan op grond van enkelvoudige gegevens en zo ja, bij welke kombinatie wordt de hoogste voorspellende waarde bereikt. De analyse zal weer apart voor kinderen en volwassenen worden verricht.

6.2 .2 . Lineaire stapsgewijze regressie analyse

op grond van de odds ratio's en $\mathrm{LR}^{+}$-waarden lijken de variabelen frekwentie, bloed, slijm en koorts bij kinderen een voorspellende warde te hebben ten aanzien van een positieve bakteriologische kweek. Bij volwassenen lijkt dit voor koorts en hoofdpijn het geval te zijn.

Ten aanzien van de kans op een positieve virologische kweek lijkt alleen bij kinderen de variabele koorts een voorspellende waarde te hebben.

Tabel 6.2.2.1 geeft een overzicht van de variabelen, die op grond van de odds-ratio en aannemelijkheidsquotiënt ( $L R^{+}$) een zekere voorspellende waarde hebben ten aanzien van de 
kweekuitslag.

TABEL $6.2 \cdot 2 \cdot 1$

overzicht van de variabelen met een $O R$ en $L R^{+}$ met een zekere voorspellende waarde $(t)$ voor een positieve bakteriële respektievelijk virologische kweekuitslag, verdeeld over twee leeftijdsgroepen.

\begin{tabular}{lcccc} 
variabelen & \multicolumn{2}{c}{ pos.bakteriële } & pos.virologische \\
\cline { 2 - 4 } & kweekuitslag & kweekuitslag \\
kind volw. & kind volw. \\
frekwentie & + & - & - & - \\
bloed & + & - & - & - \\
slijm & + & - & - & - \\
koorts & + & + & + & - \\
hoofdpijn & - & + & - & -
\end{tabular}

Van deze variabelen is onderzocht in hoeverre zij signifikant met de kweekuitslag samenhangen en hoe sterk dat verband is. Om praktische redenen is bij wijze van compromis hier gebruik gemaakt van een stapsgewijze Iineaire regressie-analyse (6), hoewel theoretisch een logistische regressie-analyse eveneens te overwegen zou zijn geweest.

Resultaten.

TABEL $6.2 \cdot 2 \cdot 2$

Kinderen: resultaat van de regressie-analyse met betrekking tot de bakteriologische kweek.

$\begin{array}{lccll}\text { predictoren } & \beta & \text { s.e. } & r & \text { o variantie } \\ \text { bloed } & .51 & .08 & .51 & 26,4 \\ \text { frekwentie } & .17 & .06 & .28 & \\ \text { koorts } & .11 & .06 & .19 & \\ \text { hoofdpijn } & .10 & .04 & .29 & \\ \text { slijm } & .03 & .07 & .22 & \end{array}$

Totaal verklaarde variantie 31,48 
*

een $\beta^{*}$ heeft een $F$ ratio, die signifikant is op het 58 -nivo.

Voor kinderen verklaren alle predictoren tesamen 31,48 van de variantie. Alleen het kenmerk bloed vertoont een signifikante samenhang en neemt ruim 848 van de totaal verklaarde variantie voor zijn rekening.

TABEL $6 \cdot 2 \cdot 2 \cdot 3$

Volwassenen: resultaat van de regressie-analyse met betrekking tot de bakteriologische kweek.

\begin{tabular}{lcccc} 
predictoren & \multicolumn{2}{c}{ volwassenen } & & \\
koorts & $\beta$ & s.e. & $r$ & o variantie \\
hoofdpijn & $.322^{*}$ & .047 & .32 & 10,4 \\
bloed & .15 & .043 & .22 & \\
frekwentie & .09 & .05 & .08 & \\
slijm & -.07 & .05 & -.00 &
\end{tabular}

Totaal verklaarde variantie: 13,98

Een $\beta$ heeft een $F$ ratio, die signifikant is op het 5\%-nivo.

Bij de volwassenen vertoont koorts een signifikante samenhang en neemt bijna 758 van de totaal verklaarde variantie van $13,9 \%$ voor zijn rekening. 
TABEL $6 \cdot 2 \cdot 2 \cdot 4$

Kinderen: resultaat van de regressie-analyse met betrekking tot de virologische kweek.

\begin{tabular}{|c|c|c|c|c|c|}
\hline \multicolumn{6}{|c|}{ kinderen } \\
\hline predictoren & $\beta$ & s.e. & r. & 8 & variantie \\
\hline koorts & .17 & .07 & .16 & & \\
\hline bloed & -.13 & .11 & -.12 & & \\
\hline braken & .06 & .07 & .11 & & \\
\hline frekwentie & -.03 & .07 & -.02 & & \\
\hline
\end{tabular}

TABEL $6.2 .2 \cdot 5$

Volwassenen: resultaat van de regressie-analyse met betrekking tot de virologische kweek.

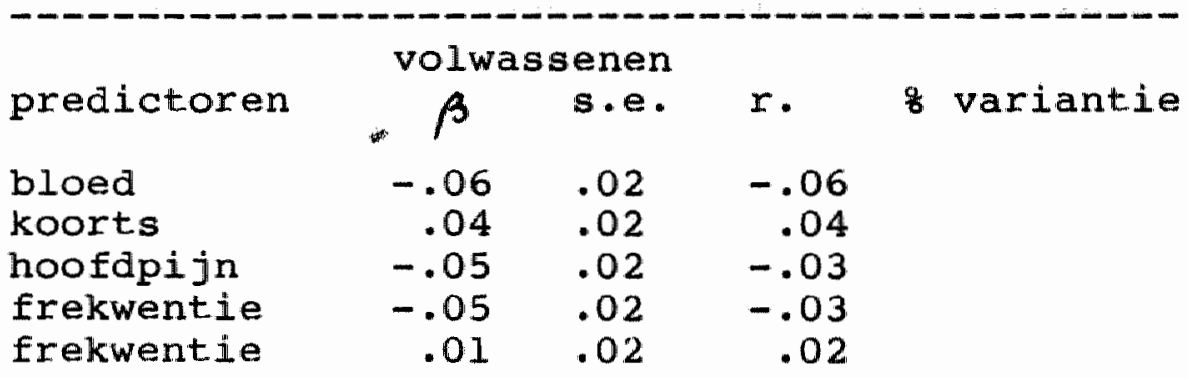

Total verklaarde variantie: $0,8 \%$

Ten aanzien van een virologische kweekuitslag is er voor kinderen noch voor volwassenen een signifikante predictie aanwezig.

Samenvattend zijn er alleen ten aanzien van een positieve bakteriêle kweekuitslag twee signifikante predictoren gevonden in de anamnese. Bij kinderen is dat de variabele bloed en bij de volwassenen de variabele koorts. 


\subsubsection{Indikatieschema}

Voor de beantwoording van het tweede vraagstuk, met name het indikatieschema, is de volgende formulering van belang: een huisartsgeneeskundig protokol is het geheel van richtlijnen voor het geneeskundig handelen in een onderzoek of behandelingssituatie dat door de beroepsgroep is geaccepteerd als meest doelmatige werkwijze om de individuele patient de beste kans te geven op een optimaal behandelingsresultaat (7). In dit onderzoek is nagegaan in hoeverre de anamnese aanleiding geeft tot het opstellen van een anamnestisch protokol c.q. indikatieschema. Dat is ten dele mogelijk gebleken.

op basis van het voorafgaande en ondersteund door de literatuur over de klacht diarree (zie ook hoofdstuk 1), voorzover het gaat om zaken die in het onderzoek zijn opgenomen, is het mogelijk het volgende indikatieschema t.a.v. de microbiële diagnostiek op te stellen.

Bij de opzet van het indikatieschema is uitgegaan van de definitie van acute diarree zoals in dit onderzoek gedefinieerd als:

drie of meermalen waterdunne of brijiige ontlasting in de laatste twaalf uur (8) en niet langer durend dan 14 dagen.

Het indikatieschema is voornamelijk bedoeld als hulpmiddel voor de huisarts om bij patienten met acute diarree via de anamnese en onderzoek enig inzicht te krijgen op het bestaan van microbiële agentia (9). Het is allereerst voor de huisarts van belang na te gaan of er werkelijk sprake is van diarree of van een afwijking van het gebruikelijke individuele ontlastingspatroon, die door de patient diarree wordt genoemd. Het schema kenmerkt zich verder door een aantal sleutelvragen, die toegang geven tot een verdere selektie van een mogelijke microbiële oorzaak en is een richtlijn bij de beslissing: wanneer wel en wanneer geen faeceskweek. In dit schema is geen indeling in leeftijdscategorieën opge- 
nomen. Alhoewel er zeker een aantal specifieke aandachtspunten $t .0 . v$. de zuigelingen, jonge kinderen enerzijds en de bejaarde patient anderzijds zijn aan te geven $(1,2,10,11)$ beoogt dit schema in eerste instantie niet dit doel.

Nog een andere reden is de mate van hanteerbaarheid. 
NCUTE DIMRate

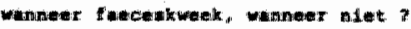

Du patiunt komit wet do knefhe:

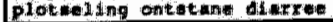

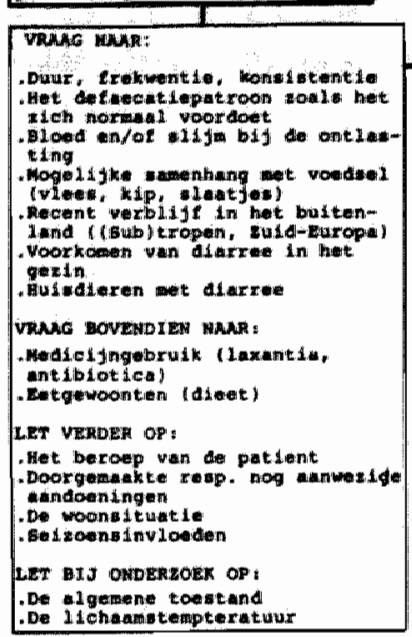

15 aprate van blow on/or

difin in to ant Iant

(t)

\begin{tabular}{|c|c|}
\hline 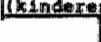 & mees \\
\hline $\begin{array}{l}\text { histelte de } \\
\text { lvolwast }\end{array}$ & $\begin{array}{l}\text { petent koortist? } \\
\text { nenl }\end{array}$ \\
\hline
\end{tabular}

1. patient in contmet gewee m

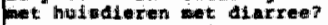

nee

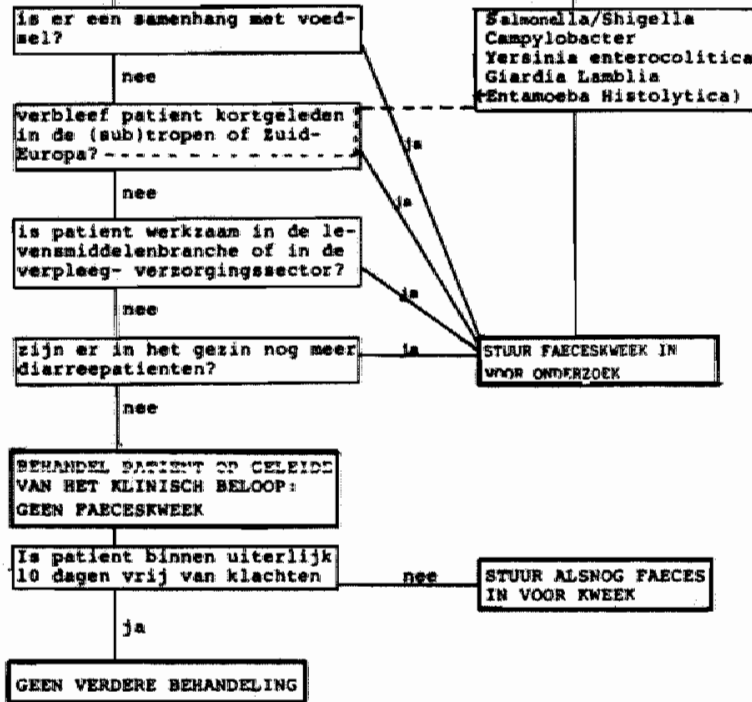

ine

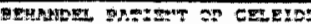

VAN HET KL TNISCH DFLOOP

VWN HET KLTMTSCH

İ patient blamen uiterlijk

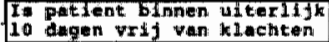

jo An:

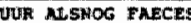
IU VOOR KWEEK

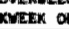

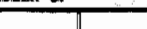

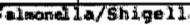

colfetea 
HOOFDSTUK 7 : KONKLUSIES EN BESCHOUWING

\section{Konklusies:}

Op grond van het uitgevoerde onderzoek kunnen de volgende konklusies worden geformuleerd:

1. De gebruikelijke anamnese in de huisartspraktijk bij de klacht acute diarree levert slechts in geringe mate bruikbare aanwijzingen op ten aanzien van het voorspellen van het bestaan van een microbiële verwekker. Er zijn een aantal onderdelen van de anamnese die, indien aanwezig bij patienten met acute diarree, een $z i j$ het geringe samenhang met een positieve kweekuitslag vertonen. Deze onderdelen zijn in volgorde van belangrijkheid: een defaecatiefrequentie van $6 x$ daags of meer, bloed bij de ontlasting, koorts, "erge" hoofdpijn en slijm bij de ontlasting.

Deze konklusie laat onverlet, dat gegevens uit de anamnese met betrekking tot het voorkomen van acute diarree in de omgeving van de patient, bijvoorbeeld in het gezin of tehuis, in de buurt of gemeente, en ook een recent bezoek van de patient aan (sub)tropische streken waardevol zijn.

2. Huisartsen nemen bij alle patienten met acute diarree meer of minder uitgebreid een anamnese af en onderzoeken in eerste instantie bijna $80 \%$ van de patienten, ongeacht de leeftijd. Ruim 758 van de patienten, die kontakt opnemen met de huisartspraktijk krijgen een medikatie voorgeschreven, hetgeen meestal een stopmiddel betreft.

Vrijwel alle patienten met acute diarree krijgen een dieetadvies of -voorschrift.

Uit de resultaten van dit onderzoek is af te lezen, dat van de patienten bij wie de huisarts, ongetwijfeld op basis van anamnese en lichamelijk onderzoek op indikatie een faeceskweek liet verrichten, het aantal 
positieve kweekuitslagen procentueel niet hoger was dan van de patienten met acute diarree waarbij altijd werd gekweekt. Uit het onderzoek bleek, dat koorts wel enige samenhang met een positieve kweek vertoonde. Dat wil niet zeggen dat het lichamelijk onderzoek bij acute diarree niet van belang is. Het gaat dan vooral om het vaststellen van de ernst van de klacht, in de zin van aanwezigheid van uitdrogingsverschijnselen.

3. Alle beperkingen, die ongetwijfeld kleven aan een telefonische enquête ten spijt, is toch in dit onderzoek gebleken, dat de huisarts op basis van de anamnese en het lichamelijk onderzoek geen betrouwbare selektie kan maken van patienten met acute diarree bij wie hij wel een microbiêle verwekker vermoedt en bij wie niet. In feite zal de huisarts elke patient met acute diarree moeten benaderen alsof er sprake is van een infektieuze diarree. Dit betekent, dat in het kader van de therapie, het geven van adviezen ter voorkoming van uitbreiding van een incidenteel geval (persoonlijke en keuken-hygiëne) niet achterwege gelaten kan worden.

Het voorschrijven van farmacotherapie, in de zin van stopmiddelen, is fakultatief. Op geleide van het beloop van de aandoening volgt eventueel een bijstelling van de therapie, waarbij er van uitgegaan moet worden, dat wanneer de klacht langer dan 10 dagen duurt, een grondig onderzoek op $z^{\prime} n$ plaats is.

4. Van de patienten met acute diarree in dit onderzoek die de hulp van de huisarts inriepen, had $37 \%$ een positieve faeceskweek wat betreft bakteriële of virale organismen. Dit percentage is in overeenstemming met de literatuur met betrekking tot de geindustrialiseerde landen (zie hoofdstuk 1). Bij patienten met acute diarree werd vaker een Campylobacter fetus ssp jejuni $(13,68)$ gekweekt dan een Salmonella bak- 
terie $(8,68)$. Bij patienten, bijwie de huisarts op indikatie kweekt zijn deze percentages 8,68 respektievelijk $7,8 \%$.

wat het verschil betreft in de frekwentie van voorkomen van Campylobacter fetus ssp jejuni tussen de groep patienten bij wie altijd werd gekweekt en de groep warbij dat op indikatie gebeurde, kan het toeval een rol spelen. Het gaat om relatief kleine aantallen. Daarbij komt dat in deze groep zich ook patienten bevonden met een iets langer durende diarreeklacht en van Campylobacter fetus ssp jejuni is bekend dat het micro-organisme al vrij snel na het begin van de diarreeklacht (4 dagen) vrijwel niet meer in de faeces is an te tonen.

Vastgesteld kon worden, dat Salmonella typhimurium het meest voorkomende type onder de Salmonellae was in dit onderzoek, hetgeen geheel in overeenstemming is met de landelijke situatie. Ten aanzien van de zoönosen kan worden gesteld, dat de Campylobacteriose wat de frekwentie van voorkomen betreft, een minstens zo belangrijke rol speelt in de huisartspraktijk als de Salmonellose.

Yersinia enterocolitica heeft, gebaseerd op de onderzoeksresultaten evenals Shigella in de huisartspraktijk maar een geringe incidentie van 1,9 respektievelijk 0,28 .

In dit onderzoek konden slechts 3 verschillende virussen: Rotavirus $(5,4 \%)$, Enterovirus $(1,9 \%)$ en Adenovirus $(0,9 \%)$ worden aangetoond bij patienten met acute diarree. De detektie strekte zich echter over aanzienlijk meer virale agentia uit (zie hoofdstuk 3). Uitgaande van de resultaten kan worden gesteld dat ten aanzien van de virale oorzaken bij de klacht acute diarree het Rotavirus $(21,5 \%)$ het voornaamste agens is en zich voornamelijk manifesteert in de kinderleeftijd.

Uit dit onderzoek blijkt verder dat bij kinderen met diarree niet zozeer aan wormen 
als oorzaak behoeft te worden gedacht.

Beschouwing.

De ervaringen opgedaan tijdens dit onderzoek geven aanleiding tot een nadere beschouwing over een aantal punten.

onderzoek in de huisartspraktijk gebeurt tot op heden veelal op basis van de persoonlijke inzet van een beperkt aantal huisartsen en onderzoekers. Door het nog vrijwel ontbreken van basisgegevens en strukturele voorzieningen voor het verkrijgen ervan is patient-gebonden onderzoek voor (huisarts)deelnemers een zeer arbeidsintensieve aangelegenheid, waar tegenover geen reguliere vergoeding stat. Deze situatie heeft de onderzoeker bij de uitvoering van dit projekt acute diarree in de huisartspraktijk ertoe genoopt vrijwel alle faciliteiten zelf te ontwikkelen. De hierna volgende opsomming van werkzaamheden kan in dit opzicht als illustratie dienen.

De eerste gesprekken met betrekking tot de opzet van een onderzoek over acute diarree in de huisartspraktijk met vertegenwoordigers van de capaciteitsgroep Medische Microbiologie van de Rijksuniversiteit en met medewerkers van het Bakteriologisch en Virologisch Laboratorium van het ziekenhuis Maastricht dateren van begin 1982 . In het najaar en de winter van 1982 /' 83 werd een proefonderzoek verricht in 5 huisartspraktijken. In april 1983 werd het projekt "Acute diarree in de huisartspraktijk" zes maanden na het indienen door de interfakultaire wetenschapscommissie van medische en algemene fakulteit van de Rijksuniversiteit Limburg goedgekeurd.

De organisatie van het projekt, met name de werving van de huisartspraktijken, de voorbereiding van de laboratoria, het ontwerpen, arukken, testen van het aanvraagformulier, de bevoorrading van de praktijken met voor dit onderzoek speciaal gekonstrueerd verpakkingsen verzendmateriaal en het bespreken van het "draaiboek" besloeg naast de reguliere werkzaamheden van de onderzoeker een periode van 8 
maanden.

In deze periode werden met betrekking tot de werving van de huisartspraktijken ongeveer 200 telefoongesprekken gevoerd.

Elke deelnemer (huisarts en doktersassistente) kreeg persoonlijke instruktie over het gebruik van het aanvraagformulier, uitleg over de telefonische enquête en over de gewenste manier van het verzenden van het materiaal. Deze gesprekken namen ongeveer 45 minuten per praktijk in beslag. Gedurende de onderzoeksperiode werden de praktijken regelmatig (om de 6-8 weken) ter ondersteuning bezocht.

Elke deelnemer inklusief de doktersassistente, hoofdanalisten en medewerkers van het Diagnostisch Centrum kreeg eens per maand een kort verslag over de resultaten met betrekking tot de microbiële verwekkers. Van deze gelegenheid werd gebruik gemaakt om gerezen knelpunten in de uitvoering van het onderzoek aan de orde te stellen.

Halverwege de registratieperiode in maart 1984 werd een avondsymposium georganiseerd voor de deelnemende huisartsen en hun assistentes. Op deze bijeenkomst werden voorlopige onderzoeksresultaten gemeld en tevens werd een demonstratie gegeven van de detektietechnieken, die voor dit onderzoek werden gebruikt.

Al deze aktiviteiten hebben als voornaamste doel gehad, het verkrijgen van valide gegevens in een werkterrein, waar geen infrastruktuur bestaat voor het verrichten van onderzoek.

Een volgend punt in de beschouwing betreft de beperking die de gevolgde onderzoeksmethodiek met zich meebracht.

In dit onderzoek is de anamnese te beschouwen als test en de kweekuitslag als ziektestatus. Hierdoor kon worden nagegaan of en in welke mate onderdelen van de anamnese afzonderlijk en in kombinatie de aanwezigheid van een microbiëel organisme kunnen voorspellen. Het kweken van een microbiëel organisme is echter nog geen bewijs met de veroorzaker van de klacht te doen te hebben. Een serologische titerbepaling (stijging) zou verricht dienen 
te worden.

$\mathrm{Nu}$ is het voorkomen van een dubbelinfektie bij een patient met acute diarree van een zo geringe omvang, dat men mag aannemen dat dit geen invioed van betekenis heeft gehad op het resultaat. Dit onderzoek is uitsluitend gebaseerd op de anamnese als opsporingselement voor de huisarts met betrekking tot het voorspellen van een positieve kweekuitslag. Men kan als bezwaar aanvoeren, dat het lichamelijk onderzoek niet in deze beschouwing is betrokken.

Met betrekking tot de anamnese en het lichamelijk onderzoek bij de klacht acute diarree is het gezien de aard van de klacht en mede gebaseerd op eigen ervaring echter duidelijk, dat primair de anamnese ten dienste staat van de diagnostiek en het lichamelijk onderzoek vooral aan de orde is bij het vaststellen van de ernst van de klacht.

Tenslotte kan nog worden opgemerkt, dat het verkrijgen van gegevens via een telefonische enquête 8 à 10 dagen na het arts-patientkontakt een element van onnauwkeurigheid met zich mee kan brengen. In het licht van hetgeen eerder in dit hoofdstuk is gezegd met betrekking tot de operationalisering van dit onderzoek kan worden gesteld, dat uit praktisch oogpunt niet anders gehandeld kon worden.

Vervolgens enige opmerkingen met betrekking tot de inhoud van de klacht. Uit dit onderzoek blijkt dat de patient nu eens de frekwentie, dan weer de konsistentie als aanduiding voor de diarree gebruikt. Tegen deze achtergrond is het aan te bevelen dat de huisarts in het begin van het arts-patient kontakt nagaat of patient en arts hetzelfde bedoelen met acute diarree. Het is zeer wenselijk dat de anamnese bij patienten met acute diarree aanvangt met vragen naar de duur, de frekwentie, de konsistentie en naar het voor de patient normale defaecatiepatroon.

De mate van uitdroging van de patient speelt een belangrijke rol bij het bepalen van de 
ernst van de klacht. Uit dit onderzoek blijkt, dat een niet onaanzienlijk deel van de patienten (ruim 16\%) met acute diarree, onafhankelijk van de leeftijd, in eerste instantie via de telefoon, hetzij door de doktersassistente, hetzij door de arts zelf van advies wordt gediend en dus niet kan worden onderzocht. In het algemeen, onafhankelijk van dit onderzoek, kan worden gezegd dat de huisarts bij kinderen en bejaarden altijd zou moeten besluiten zelf vast te stellen of en zo ja in welke mate er uitdroging bestaat. overigens is het sterk aan te bevelen dat er een werkschema voor de doktersassistente met betrekking tot deze en andere zogenaamde "minor ailments" wordt opgesteld.

Bij de klacht acute diarree is het van belang uitbreiding van een incidenteel geval te voorkomen.

Voor de huisarts betekent dat onder meer dat hij op de hoogte moet zijn van het beroep van zijn patient of de gezinsleden, waarbij het voornamelijk gaat om beroepen in de zogenaamde open levensmiddelenbranche, de verpleging of verzorging in verband met de risicoberoepen. $B i j$ verdenking van een infektieuze diarree bij deze personen maar ook bij bewoners in tehuizen en inrichtingen en indien meerdere personen in één gezin diarree hebben of wanneer er sprake is van een persisteren van de klacht (langer dan 10 dagen), is het kweken van de faeces zinvol. Overigens is het aan te bevelen dat er in tehuizen en inrichtingen, waar doorgaans meer huisartsen patienten bezoeken een centrale meldingsplaats met betrekking tot infekteuze aandoeningen wordt ingericht.

In zijn algemeenheid kan gesteld worden dat het gevaar voor uitbreiding van de klacht drastisch verminderd zou kunnen worden, indien voedingsmiddelen op de juiste temperatuur worden klaargemaakt (voldoende lang verhit) en op een korrekte wijze worden bewaard (snelle afkoeling). Besmetting in de keuken, en dat geldt niet alleen in bedrijfskeukens, van eenmaal klaargemaakt voedsel kan door regelma- 
tig wassen van de handen en het reinigen van het keukengereedschap beperkt worden.

Tenslotte enige aandacht voor het epidemiologisch aspekt van acute diarree. Het is gebleken dat het symptomenkompleks niet specifiek is. Tevens is het duidelijk, dat het altijd kweken van de faeces bij deze klacht door alle huisartsen, afgezien van de kosten, in het opzicht van behandeling geen zinvolle aktiviteit is. Dat betekent dat er geen epidemiologische gegevens worden vastgelegd, die een betrouwbaar inzicht geven over het voorkomen van micro-organismen.

In aanvulling op de bestaande voorziening is het met betrekking tot de gastro-enteritis aan te bevelen aan te sluiten bij de bestaande ontwikkelingen in Nederland ten aanzien van peilstations. Huisartspraktijken gebundeld tot een regionaal station kunnen zich in tegenstelling tot de individuele praktijk, ontwikkelen tot goede centra met betrekking tot het leveren van gegevens over het voorkomen van micro-organismen in dat gebied. In een dergelijk regional station kan bijvoorbeeld gedurende een bepaalde termijn wel van alle patienten met acute diarree een faeceskweek worden verricht. In deze huisartspraktijken, die eventueel per toerbeurt voor een bepalde periode tot het regionale peilstation zouden kunnen behoren, kunnen dan een aantal peilgezinnen als bronnen voor de gegevensverzameling met betrekking tot deze en wellicht ook andere infektieuze aandoening dienst doen.

op deze wijze kan met een beperking van de kosten vrijwel kontinue gegevens verzameld worden over infektieuze aandoeningen en hun verwekkers in het eigen werkterrein van de huisarts. Daarbij komt dat door middel van dit systeem alle huisartsen van een bepalde regio maar ook daarbuiten op elk gewenst moment voorzien kunnen worden van informatie over de aard en frekwentie van voorkomen van een bepaalde verwekker. 
Het opzetten en ontwikkelen van dergelijke peilstations zou moeten behoren tot het werkterrein van de Basis Gezondheids Dienst.

Tijdens dit onderzoek werd ik me nog eens bewust van de belangrijke plaats die de huisartspraktijk inneemt c.q. kan innemen. De huisarts heeft in zijn relatie met de patient onbelemmerd toegang tot een belangrijke bron van epidemiologische gegevens. Voor de huisarts ligt in het participeren aan peilstations een mogelijkheid een bijdrage te leveren aan het verzamelen van zogenaamde eigen epidemiologische gegevens ter ontwikkeling van het vakgebied. Hij kan, door zich op deze wijze in te schakelen, wellicht voorkomen als leverancier van onderzoeksgegevens te worden beschouwd voor vakgebieden die niet a priori tot de zijne behoren. De ontwikkeling van huisartsgeneeskunde zonder valide gegevens, voortspruitend uit een eigen onderzoeksveld, is vooralsnog bouwen op drijfzand. 
SAMENVATTING

Dit onderzoek heeft voornamelijk betrekking op twee gebieden:

1. Het handelen van de huisarts bij patienten met acute diarree.

2. Het vóórkomen van microbiële verwekkers van acute diarree in het werkterrein van de huisarts.

De gegevens uit de literatuur, zoals beschreven in hoofdstuk 1 en 2 , vormen het kader wartegen de eigen onderzoeksgegevens zijn afgezet.

In hoofdstuk 1 worden indelingen en oorzaken van acute (infektieuze) diarree een de orde gesteld. De indelingen zijn veelal gebaseerd op pathofysiologische processen of op het voorkomen van typen infektieuze diarree.

De kennis van de verwekkers van acute diarree, m.n. van een toeneming aantal nieuwe virussen en van de pathofysiologie van infektieuze diarree is de latste 10 jaar sterk vermeerderd.

In dit hoofdstuk worden besproken Salmonella, Shigella, Campylobacter fetus ssp jejuni, Yersinia enterocolytica, Toxicogene Escherichia coli/Reizigersdiarree, Rota-, Norwalk-, Adenovirus en van de parasieten Entamoeba histolytica en Giardia Lamblia.

In paragraaf 1.6 .5 . en 1.7 .1 . wordt een overzichtstabel gegeven van de voornaamste eigenschappen van belangrijke bakteriële respektievelijk virale oorzaken van acute diarree.

In hoofdstuk 2 wordt een literatuuroverzicht gegeven van het handelen van de huisarts bij de klacht acute diarree. Aan bod komen de anamnese, het lichamelijk onderzoek, het gebruik van laboratoriumfaciliteiten, de farmacotherapie en het beleid.

Uit de literatuur wordt het duidelijk dat het 
benadrukken van de importantie van onderdelen van de anamnese ook te maken heeft met de plats, die de auteurs in het gezondheidszorgsysteem innemen.

Startpunt in de anamnese voor de huisarts is het vragen nar de duur, de frekwentie en konsistentie van de acute diarree en het vragen naar het voor de patient normale defaecatiepatroon. Vervolgens is het van belang na te gaan of en $z o$ ja welke samenhang er bestaat met onder meer voedsel, verblijf in (sub)tropische streken, geneesmiddelengebruik (met name antibiotica, laxantia), voorkomen in het gezin of leef- of werkgemeenschap, zieke huisdieren, het seizoen, bijkomende klachten als bovenste luchtweginfekties (met name bij kinderen), arthralgieën en erythema.

$\mathrm{Bij}$ het lichamelijk onderzoek is de mate van uitdroging een waardevol beoordelingsinstrument voor de huisarts voor de ernst. In die zin wordt een telefonische afhandeling van de klacht, vooral als het om kinderen gaat, in de literatuur ontraden.

Laboratoriumonderzoek bij een niet zieke patient met diarree wordt niet zinvol geacht. Een faeceskweek wordt met name in het kader van preventie in overweging gegeven bij patienten, bij wie sprake is van een zeker beroepsrisiko, bij een explosie, bij patienten in een gesloten woon- of leefgemeenschap of wanneer er recent sprake was van een verblijf in (sub)tropen of Zuid-Europa.

Het zwaartepunt in de behandeling van patienten met acute diarree is gelegen in de vochttoevoer tot herstel van de elektrolytenbalans en bij adviezen ter voorkoming van verspreiding van incidentele gevallen. Standaardoplossingen voor orale rehydratie lijken met betrekking tot het gevaar van onjuiste samenstelling de voorkeur te genieten boven eigen gemaakt mengsel.

Hoofdstuk 3 beschrijft de methode van onderzoek en geeft een precisering van de onderzoeksvragen. 
Ten behoeve van dit onderzoek werden 25 huisartspraktijken in de regio Heuvelland gestratificeerd naar de kenmerken solo/nonsolopraktijk, stad/omgeving en vervolgens at random verdeeld over een groep $A$ en een groep B. In groep $A$ werden van alle patienten met acute diarree via een faeceskweek volgens een standaardprocedure micro-organismen gedetekteerd. In groep $B$ werd enkel op indikatie een faeceskweek aangevraagd. Alle huisartspraktijken zijn gelegen binnen het verzorgingsgebied van het Diagnostisch centrum van het ziekenhuis Maastricht.

voor het onderzoek naar de microbiële verwekkers wordt verwezen naar hoofdstuk 3 .

In totaal verleenden 37 huisartsen en hun doktersassistenten medewerking op een totaal van 65 huisartsparticipanten van het Diagnostisch Centrum. De gegevens met betrekking tot de anamnese, lichamelijk onderzoek, therapie en beleid van het eerste kontakt van de patient of diens verzorger werden vastgelegd op een speciaal daartoe ontworpen aanvraagformulier (bijlagen I en II). Ter kompletering van deze gegevensverzameling en om informatie over het beloop van de klacht te verkrijgen werd een follow-uponderzoek verricht 8 à 10 dagen na het kontakt van de patient met de huisartspraktijk (bijlage VI). via dit onderzoek konden tevens gegevens verzameld worden m.b.t. het voorkomen van acute diarree in het gezin van de patient tijdens zijn ziekteperiode. Ruim $80 \%$ van de patienten kon via de telefoon bereikt worden.

In hoofdstuk 4 worden de resultaten gegeven van de telefonische enquête met betrekking tot de anamnese en het beloop van de klacht. Bij de anamnese gaat het on de onderdelen: duur, frekwentie, konsistentie, kleur, bijmengingen bloed en slijm bij de ontlasting, braken, buikpijn/krampen, koorts, "erge" hoofdpijn en ziektegevoel. De resultaten worden vrijwel steeds gegeven voor 3 leeftijdskategorieän: zuigelingen van $0 t / m 12$ maanden, kinderen van $1 \mathrm{t} / \mathrm{m} 10$ jaar en vol- 
wassenen van 11 jaar en ouder.

Bloed bij de ontlasting komt bij de drie leeftijsgroepen in vrijwel dezelfde percentages voor respektievelijk $12,58,15,08$ en 13,48 .

Slijm bij de ontlasting komt meer voor bij zuigelingen en kinderen dan bij volwassenen respektievelijk $66,78,49,28$ en 40,88 .

Braken komt bij acute diarree bij iets meer dan een kwart van de zuigelingen, bij bijna de helft van de kinderen en bij bijna eenderde van de volwassenen voor. Koorts en koortsig gevoel zijn voor de patient vaak identieke begrippen. Uitgaande van de gemeten temperatuur volgens opgave van patient of diens verzorger bleek 458 van de zuigelingen, 38,58 van de kinderen en 34,48 van de volwassenen gedurende de ziekteperiode één of meer keren een temperatuur van hoger dan 37,58 te hebben wargenomen.

Opvallend in de anamnese is de bijna 408 volwassenen, die aangeeft "erge" hoofapijn te hebben van een intensiteit dat niet van een gewone hoofdpijn gesproken kan worden. Een ruime meerderheid van de patienten (70\%) of diens verzorger geeft aan zich ziek te voelen van deze op het oog eenvoudige klacht.

Van de patienten die de huisarts konsulteerden werd ongeacht de leeftijd ruim 758 lichamelijk onderzocht, en bij totaal 88 o het abdomen.

De huisartsen in dit onderzoek verrichtten vrijwel nooit (98\%) eigen laboratoriumonderzoek bij de klacht acute diarree en vroegen ook zelden laboratoriumonderzoek aan $(3,7 \%)$. Opmerkelijk was het hoge aantal medicijnvoorschriften bij deze klacht. Bijna $60 \%$ van de kinderen en ruim $80 \%$ van de volwassenen kreeg een geneesmiddel van de huisarts voorgeschreven en gaven te kennen dit ook te gebruiken, waarbij het vrijwel altijd on een stopmiddel ging.

In het kader van de preventie zijn opmerkingen of adviezen over de besmettelijkheid en hygiëne van belang. Afzonderlijk kwamen deze 
aspekten ruim aan de orde in de voorlichting van de patient door de huisarts. Toch kreeg in dit onderzoek maar iets meer dan $40 \%$ van de patienten die voorlichting ontvingen, informatie over beide aspekten.

In dit onderzoek is via een telefonische enquête follow-up onderzoek gedaan naar het beloop van de klacht, zij het beperkt tot een termijn van 8 à 10 dagen. Uit het onderzoek bleek, dat gerekend van het eerste arts-patientkontakt kinderen langer klachten van diarree houden dan volwassenen. $25 \%$ van de kinderen en ruim $15 \%$ van de volwassenen hadden 5 tot 8 dagen na het kontakt met de huisartspraktijk diarree of althans voor de patient geen normale ontlasting. 8-10 dagen na dit kontakt gaf bijna $90 \%$ van de patienten aan, geen klachten meer te hebben. In dit onderzoek gaf bijna $30 \%$ van de volwassenen aan van deze klacht 7 dagen of langer ziek te zijn geweest.

Met behulp van het follow-up onderzoek kon worden nagegaan hoeveel personen in het gezin van de patient die de huisarts niet konsulteerden, ook diarree hadden.

In $35,6 \%$ van de gezinnen waarbij één van de gezinsleden de hulp van de huisarts inriep, waren er ook andere gezinsleden die diarree hadden. Wanneer de patient een kind was bleken signifikant $(p<0,0001)$ meer gezinsleden diarree te hebben dan wanneer de patient een volwassene betrof.

In hoofdstuk $5 \mathrm{zijn}$ de resultaten weergegeven van het voorkomen van microbiële agentia bij patienten met acute diarree (groep A) en bij patienten met acute of iets langer durende diarree (groep B).

Van patienten met acute diarree (groep A) die de hulp van de arts inriepen kon in dit onderzoek bij $37 \%$ een positieve kweekuitslag worden vastgesteld, warbij in 23,98 een bakteriëel organisme werd ontdekt en in $13,2 \%$ 
een viraal agens. Campylobacter fetus ssp jejuni kwam in $13,6 \%$ voor, Salmonella in 8,38 (waarbij Salmonella typhymurum het meest voorkomende type was), Yersinia enterocolitica in 1,98 en Shigella in 0,28 .

Campylobacter fetus ssp jejuni neemt uitgaande van deze percentages ten opzichte van het voorkomen een minstens zo belangrijke plaats in bij de zoönosen als de salmonellae. In 21,58 van de kinderen met acute diarree is er sprake van een viraal agens tegenover 2,28 bij de volwassenen.

Het uiteindelijk resultaat van de virusdetektie heeft zich beperkt tot 3 typen Rota-, Entero- Adenovirus (respektievelijk 138, 5,78 en $2,8 \%$ ), waarbij het Rotavirus verreweg het meest voorkomende type is met een duidelijke voorkeur voor de kinderen.

Bij patienten (groep B) van wie op indikatie een faeceskweek werd verricht, kwamen salmonella $(7,8 \%)$ en Campylobacter fetus ssp jejnui $(8,68)$ in een vergelijkbaar percentage voor. ook nu spelen Yersinia enterocolitica $(0,8 \%)$ en Shigella $0,4 \%)$ een ondergeschikte rol bij het voorkomen. Salmonella typhimurum bleek ook bij deze groep patienten het meest voorkomende type. Ten aanzien van de virusdetektie week het beeld niet wezenlijk af van de patienten van groep $A$.

Ten aanzien van de seizoensgebondenheid werd gevonden, dat Salmonella een voorkeur heeft voor de zomer en het vroege najaar. Campylobacter komt het gehele jaar voor met een kleine top in de zomer en het Rotavirus komt het meest in de winter voor.

Tot slot van dit hoofdstuk wordt er aandacht besteed aan de fundamentele vraag of het laten kweken van de faeces bij patienten met acute diarree door de huisarts wel zinvol is. Het kweken van de faeces komt in aanmerking: 1. In geval van aanknopingspunten als:

- recent verblijf in de (sub)tropen

- werkzaam in open levensmiddelenbranche, verpleging of verzorging 
- wonend in besloten gemeenschappen (te huizen, inrichtingen)

- uitbreiding van de diarree bij twee of meer personen in één gezin

2. Indien de diarree langer dan 10 dagen aanhoudt of onvoldoende reageert op de therapie.

In hoofdstuk 6 worden de resultaten vermeld van de analyse van het volgende vraagstuk:

Is de anamese (of onderdelen ervan) een geschikt instrument voor uitspraken over de samenhang van de klacht acute diarree en het voorkomen van een bepaald micro-organisme in de faeces?

De analyse werd uitgevoerd op basis van likelihood- en odds ratio's, een linealre stapsgewijze regressieanalyse.

Uitgaande van de likelihood- en odds ratio's bleek vooral de a nwezigheid van een hoge defaecatiefrekwentie, de bijmengingen bloed en slijm en het voorkomen van koorts in de anamnese een grotere kans op een positief microbiëel kweekresultaat te bieden, zij het dat er sprake was van een wisselende samenhang, voor de verschillende leeftijdsgroepen (kinderen en volwassenen).

Koorts in de anamnese bleek bij alle patienten een grotere kans te bieden op een positieve kweekuitslag. In de regressie-analyse bleek dat van de genoemde onderdelen van de anamnese koorts en bloed konden worden aangemerkt als de voornaamste faktoren, die verantwoordelijk waren voor de totale variantie. Toch was er sprake van een zeer bescheiden verklaring.

Uitgaande van de resultaten van de analyses kon worden gekonkludeerd dat de anamnese (of onderdelen ervan) weinig voorspellende waarde heeft voor het bestaan van een positieve kweekuitslag.

Het hoofdstuk besluit met een indikatieschema voor de huisarts in de $z$ in van het aanvragen van faeceskweek bij de klacht acute diarree op basis van dit onderzoek zoals beschreven 
in hoofdstuk 5 en 6 en de literatuur.

Hoofdstuk 7 bevat de konklusies en beschouwing.

Voornaamste konklusies:

1. De gebruikelijke anamnese in de huisartspraktijk bij de klacht acute diarree levert slechts in geringe mate bruikbare aanwijzingen op ten aanzien van het voorspellen van het bestaan van een microbiêle verwekker. De onderdelen van de anamnese: defaecatiefrekwentie van $6 x$ daags of meer, bloed bij de ontlasting, koorts, erge hoofdpijn en slijm bij de ontlasting vertonen in deze volgorde van belangrijkheid een geringe samenhang met een positieve kweekuitslag.

2. Op basis van de anamnese en het lichamelijk onderzoek kan de huisarts geen selektie maken van patienten met acute diarree bij wie hij wel een microbiële verwekker vermoedt en bij wie niet.

De huisarts zal elke patient met acute diarree moeten benaderen alsof er sprake is van een infektieuze diarree.

Dit betekent dat ten aanzien van de therapie het geven van adviezen ter voorkoming van uitbreiding van een incidenteel geval, niet achterwege gelaten kunnen worden.

3. Van de patienten met acute diarree, die de hulp van de huisarts inriepen, had $37 \%$ een positieve faeceskweek, in de $z$ in van een bakterieel of viraal micro-organisme.

Vastgesteld kon worden dat Salmonella typhimurium het meest voorkomende type onder de Salmonellae is.

Ten aanzien van de zoönose speelt de Campylobacteriose wat de frekwentie van voorkomen betreft een minstens zo belangrijke rol in de huisartspraktijk als de Salmonellose.

Yersinia enterocolitica heeft evenals de Shigellae mar een geringe incidentie $(1,98$ resp. 0,28$)$ in de huisartspraktijk. In dit onderzoek konden slechts 3 verschillende virussen Rotavirus $(5,4 \%)$ Enterovirus 
$(1,98)$ en Adenovirus $(0,98)$ worden aangetoond, terwijl de detektie zich over aanzienlijk meer virale agentia uitstrekte. Uitgaande van dit onderzoek kan worden gesteld, dat ten aanzien van de virale oorzaken bij acute diarree het Rotavirus het voornaamste agens is en zich voornamelijk manifesteert in de kinderleeftijd.

Tenslotte kwam uit de resultaten van dit onderzoek naar voren, dat bij kinderen met (acute) diarree niet zozeer aan wormen als oorzaak behoeft te worden gedacht.

In de nabeschouwing worden een aantal onderwerpen, die samenhangen met de hier gevolgde methode van onderzoek, besproken.

Ten eerste wordt aandacht besteed aan de problemen die het verrichten van onderzoek in huisartspraktijken met zich meebrengt vanwege het feit dat basisgegevens en strukturele voorzleningen vrijwel ontbreken.

Deze situatie heeft ertoe geleid, dat de onderzoeker vrijwel alle faciliteiten voor de uitvoering van het projekt "Acute diarree in de huisartspraktijk" zelf heeft moeten ontwikkelen. Er wordt ter illustratie een opsomming van de werkzaamheden gegeven.

Ten tweede wordt er gesproken over de beperkingen die een onderzoek als het onderhavige naar acute diarree met zich mee kan brengen. Het gaat daarbij om het gegeven dat aanwezigheid van microbiele agentia in de faeces nog geen bewijs zijn met de veroorzaker van de klacht te doen te hebben. Ook wordt de dominante rol van de anamnese als diagnosticum ten opzichte van het lichamelijk onderzoek besproken.

Vermeld wordt dat ondanks een mogelijke beperking die het gebruik van een telefonische enquête in een onderzoek met zich mee kan brengen, uit praktisch oogpunt niet anders gehandeld kon worden.

Het derde deel van de beschouwing bevat een aantal aanbevelingen voor de huisarts, geënt op zijn plaats in het gezondheidszorgsysteem. 
- Van belang is dat de huisarts bij de start van de anamnese bij een patient met acute diarree nagaat of patient en arts hetzelfde bedoelen met acute diarree en wat het voor de patient normale defaecatiepatroon is.

- Vervolgens als de huisarts overweegt te kweken, dan zijn het voorkomen van bloed bij de ontlasting en koorts belangrijke faktoren die aangeven werkelijk met een microbiële oorzaak te doen hebben?

- Huisartsen zouden moeten besluiten bij kinderen en bejaarden altijd zelf vast te stellen of en zo ja in welke mate er uitdroging bestaat.

- Het moet alleszins zeer waardevol worden geacht een werkschema voor de doktersassistente op te stellen met betrekking tot deze en andere zogenaamde "minor ailments".

- Ter voorkoming van uitbreiding van een incidenteel geval bij infektieuze diarree is het an te bevelen een centrale meldingsplaats in te richten in (verzorgings)tehuizen c.q. inrichtingen.

- Adviezen ter voorkoming van kruisbesmetting (regelmatig handen wassen en reinigen van keukengereedschap) zal het gevaar voor uitbreiding van de klacht in het gezin verminderen.

Tenslotte wordt enige aandacht besteed aan het epidemiologisch aspekt van acute diarree. op epidemiologische gronden is het an te bevelen over te gaan tot uitbreiding van regionale peilstations, op toerbeurt gevorma door een aantal huisartspraktijken. In deze stations kunnen peilgezinnen in het algemeen met betrekking tot het voorkomen van microorganismen ondersteuning geven ten opzichte van de kontinü̈teit van de gegevensverzameling in een regio.

Dit geeft onder meer een mogelijkheid tot informatie aan de huisarts over het voorkomen van infektieuze aandoeningen in de eigen streek en werkterrein. 
This study has been mainly devoted to two aspects :

1. How the general practitioner deals with patients suffering from acute diarrhoea.

2. The frequency of occurrence of various microbial agents in causing diarrhoea in general practice patients.

The literature study in chapter 1 and 2 designs the framework of this investigation. Chapter 1 presents the classification and causes of acute (infectious) diarrhoea in such patients. Classification in the literature is usually based on pathophysiological processes or on the occurence of types of infectious diarrhoea. The know-how of the occurence of microbial agents, especcially new virus agents and the pathofysiology of infectious diarrhoea has been strongly increased in the last decade.

The following agents are discussed in this chapter: Salmonella spp., Shigella spp., campylobacter jejuni, Yersinia enterocolitica, toxigenic strains of Escherichia coli. travellers' diarrhoea (ETEC), Rotavirus, Norwalk agent and Adenovirus, together with the parasites Entamoeba histolytica and Giardia Lamblia.

In section 1.6 .5 and 1.7 .1 a simple schedule of the most important bacterial and viral agents is given.

In chapter 2 a review of the literature is presented concerning the way the general practitioner deals with the complaint of acute diarrhoea. The history of the patient, physical examination and the use of laboratory facilities are discussed together with any necessary pharmacotherapy.

It is clear from the literature that emphasis on the different component parts of the patients' history is often related to the place that the authors of the publications occupy in the health care systems. The start of history 
taking by the general practitioner is usually a question concerning the duration of the diarrhoea and the frequency and consistency of the faeces and comparison of this with the defaecation pattern normal for that individual patient. Thereafter, it is important to consider whether or not there is any connection with particular items of food, visits to (sub)tropical lands, use of pharmaca (in particular, antimicrobial agents and laxatives) and wether there are any sick domestic animals in the family environment, place of work or in the neighouring community. Moreoever, the season of the year and the presence of other complaints such as upper respiratory tract infections (in particular in children), pain in the joints, and erythema may all be important.

Physical examination will show the degree of dehydration and may be a valuable instrument for the first judgement of the general practitioner corncerning the severity of the disease. In particular, the literature has shown that the general practitioner should not rely on telephone consultations over such patients, particularly when young children are concerned.

Laboratory investigations are not considered very relevant when the patient is not acutely ill. Culture of the faeces is usually considered more for the prevention of an epidemic than as an important factor for the treatment of the individual patient. In particular, such culture appears to be important when there is a occupational risk, when an explosion threatens, when the patient lives in a closed community and whenever there is the suspection that the patient has recently visited tropical or subtropical lands ( or Southern Europe). The main emphasis in the treatment of patients with acute diarrhoea is the replenishment of fluids until the electrolyte balance has been corrected, but giving advice corncerning the prevention of further spread of the disease 
may sometimes be important. Standard oral rehydration solutions appear to be preferable to home-made ones, the composition of which may be entirely incorrect.

Chapter 3 describes the methods used for this investigation and presents the questions which were posed. In the Heuvelland region 25 general practices were stratified for the purpose of this study according to the following characteristics: single/non-singlehanded practice, town/out of town, and the practices were also divided randomly into a group of practices $A$ and a group $B$. In group A, as many patients as possible suffering from acute diarrhoea were detected after examination of the faeces had been performed according to a standardised procedure. In group $B$, the practices only arranged faecal culture on specific indications. Alle the general practitioners involved in this study were situated within the area served by the Diagnostic Centre of the University Hospital at Maastricht. The following studies were carried out in all patients:

Salmonella/Shigella/Campylobacter jejuni/Yersinia enterocolitica/Rotavirus/Enterovirus/Adenovirus/Poliovirus 1-3/Coxsackie virus A1-A27/Coxsackie virus B1-B27/Echovirus 137 /Reavirus 1-3/Hepatitis A-virus/Calicivirus/Parvovirus/Norwalk virus/Picornavirus. Moreover, cysts and worm eggs were sought in all children under ten years of age.

A total of 37 general practitioners and their practice assistents joined in this study, giving a total of 65 general practice participants together with the Diagnostic Centre. Data concerning the history, physical examination, treatment and policy concerning the first contact with the patient or his representative were noted on specially developed series of proformata (appendices $I$ and II in this thesis). The data collection was completed by registering information about the courses of the complaint which was obtained 
during a follow-up study 8-10 days after the first contact with the practice (appendix III). In this way data on any occurence of acute diarrhoea in the family during the index patients' illness could be collected. Approximately $80 \%$ of the patients could be contacted by telephone.

Chpater 4 decribes the results of the telephone enquiry concerning the history and the course of the symptoms. The history discussed the following details: the duration and frequency of the diarrhoea and the consistency and colour of the faeces together with any admixture of blood and mucus, the presence of vomiting, abdominal pain and cramps, fever, severe haedache, and feeling of general illness. The results were usually presented 3 age groups: babies from 0 to 12 months of age, children from 1 to 10 years, and "adults" of 11 years and older. The presence of blood in the faeces was also examined in the three age groups of patients and the resultst were 12.5 , 15.0 and $13.4 \%$, respectively. The presence of mucus in the faeces was more often noted in babies and in children than in adults. It was present in $66.7 \%, 49.28$ and 40.88 of the respectice groups. Vomiting was noted in slightly more than a quarter of the babies, in almost half of the children and in nearly one third of the adults.

Fever and a feeling of feverishness often amount to the same for the typical patient. When the temperature was actually measured by the patient or his attendant, it appeared that $45 \%$ of the babies, $35.5 \%$ of the children and 34.48 of the adults had a temperature higher than $37.5^{\circ}$ at least once during the period of the illness. It was impressive to note in the history that almost $40 \%$ of adults who claimed "severe" headache said that this was out of proportion to the "normall" haedaches that they had experienced. The great majority of patients $(70 \%)$ and their attendants claimed that the diarrhoea patient was "all" and this 
appeared to them to be a simple matter. of the patients who did consult the general practitioner approximately $75 \%$ were examined physically, and $88 \%$ of them also underwent abdominal examination, regardless of age. General practitioners hardly ever (98\%) carry out their own laboratory investigations on patients with acute diarrhoea and very rarely request laboratory studies $(3.78$ only). The large numer of medicine prescriptions for patients with this compliant was remarkable. Almost 608 of the children and more than $80 \%$ of the adults received a prescription from the general practitioner and claimed that they had indeed taken the medicine, even tough it was usually a faeces thickener. Within the general framework of preventive procedures, it is important to consider whether attention was devoted and advice given over the spread of infection and the use of hygienic procedures. The provision of this information by the general practitioner was also investigated but only just over $40 \%$ of patients received the necessary advice on both these aspects.

This investigation also went further to include the telephone enquiry follow-up over the course of the compliants, albeit restricted to a period of 8-10 days. From the study it appeared that children had complaints of diarrhoea for much longer than the adults did after the first doctor-patient contact. Appro$x$ imately 258 of the children and $15 \%$ of the adults still had diarrhoea (or at least did not produce normal formed stools) for 5 to 8 days after the first contact with the general practitioner. After 8 to 10 days following this contact more than 908 of the patients declared that they had no longer any symptoms. In this study almost $30 \%$ of the adults claimed to have been $i l l$ for 7 days or more.

By means of the follow-up study it was possible to check how many people in the patients' family also had diarrhoea but had not consulted the general practitioner at all. In $35.6 \%$ 
of the families containing one member who had called upon the general practitioner for help, there were other family members with diarrhoea. Whenever the patient was a child there were significantly more ( $P=\langle 0.0001)$ other family members with diarrhoea than when the index patient was an adult.

In chapter 5 the results are presented of the frequency of occurrence of various microbial agents in patients with acute diarrhoea (group A) and in patients with either acute or rather longer lasting diarrhoea (group B). In the patients with acute diarrhoea who consulted their practitioners it could be concluded from this study that $37 \%$ yielded a positive stool examination and this amounted to a bacterial isolate in 23.98 and a viral agent in 13.28 . The most common organism was Campylobacter jejuni (in 13.6\%), followed by salmonella spp. in $8.3 \%$ (of which the most common serotype was Salmonella typhimurium). Yersinia enterocolitica was recorded in 1.98 and Shigella spp. in 0.28 . Campylobacter jejuni would appear from these percentages to occupy at least as important a place in these zoonoses as the various salmonellae. In $21.5 \%$ of the children with acute diarrhoea, however, there was a viral agent, compared with only 2.28 among the adults. The final results of virus investigations yielded only 3 groups: Rotavirus, Enterovirus and Adenovirus, amounting to 138, 5.7\% and $2.8 \%$, respectively, from wich it is obvious that the Rotavirus was by far the most common type and had an obvious preference for children. In the patients among group $B$ in whom a faeces culture was only carried out on indication, Campylobacter jejuni (8.68) and Salmonella spp (7.88) were found in comparable percentages. Yersinia enterocolitica (0.8\%) and Shigella spp $(0.48)$ also played a subordinate role in these patients and salmonella typhimurium was again the most common serotype of this group of organisms. The results of the virological studies in patients of group $B$ were not very different from those noted in 
group A.

It can be concluded that salmonella infections show a preference for the summer and early autumn, whereas campylobacter infections are found throughout the whole year with an extra numer in the summer. Rotavirus is found mostly in the winter months. The last section of this chaper pays attention to the fundamental question whether culture (including virology) of the faeces in patients with acute diarrhoea is useful for the general practitioner. Faecal cultures are considered:

1. In the case of particular indications such as :

- recent visit to the tropics and subtropics

- work in catering or food supply industries, nursing or patient care

- living in closed communities such as institutions, mental hospitals, etc.

- spread of the diarrhoea to two or more persons within one family

2. Whether or not the diarrhoea persists for more than 10 days or fails to respond to treatment.

Chapter 6 presents the results of the analysis of the following problem:

Is the history (or any part of it) a suitable instrument for giving any statement over the relation between the complaint of acute diarrhoea and the occurence of any particular micro-organism in the faeces? This analysis was carried out by means of likelihood- and odds ratios and by a linear stepwise regression analysis (correlation procedures: Chisquare, Pearson, R., and the P-value). Considering the likelihood- and odds ratio, it appeared that the presence of frequent defaecation, the presence of blood of mucus in the faeces and the occurence of fever in the history all yielded greater chances of a positive mivcrobiological result. However, the connection was not always constant and varied with the different age groups (children and 
adults). Fever in the history appeared to produce a greater chance of positive laboratory resultst in all patients. It appeared from the regression analysis results that the questions concerning fever and the presence of blood in the faeces could be considered as the most important factors, and these were responsible for the total variance. However, it was thought that there was a possible explanation. In general, it was not considered from the various analysis that the history or any component parts of it yielded much prophetic value for a positive faeces culture. The chapter concludes with a indication scheme for the general practitioner confronted with the complaint of acute diarrhoea based on the sultats from this investigation and from the literature as described in chapter 5 and 6 .

Chapter 7 contains the conclusions and discussion.

The general conclusions are:

1. The customary method of history taking in general practice in patients with the compliant of acute diarrhoea only produces few indications of the microbial cause. Aspects of the history such as defaecation frequency of six times a day or more, the presence of blood in the stools, fever, severe headache and the appereance of mucus in the faeces show (in this order of importance) a certain degree of correlation with a positive culture result.

2. On he basis of the history and physical examination, the general practitioner is not provided with much information for discriminating between patients who have and those who do not have microbial agents as causes of the diarrhoea. The practitioner will therefore need to approach each acute diarrhoea patient as if it was a case of acute infectious diarrhoea. This implies that advice (as part of the therapy) on the prevention of spread within the household can not be omitted.

3. A total of $37 \%$ of the patients with acute 
diarrhoea who called upon the general practitioner did have a positive laboratory test result on the faeces with either a bacterial or viral organism isolated or demonstrated. Furthermore, it was shown that Salmonella typhimurium was the most frequent type of the salmonellae found. As far as the zoones are concerned, campylobacteriosis played at least as important a part in domiciliary practice as did the salmonellae. Yersinia enterocolitica and Shigella spp (1.98 and 0.28$)$ ware seldom encountered in general practice.

In this study only three different virus groups were demonstrated, namely: Rotavirus (5.4\%), Enterovirus (1.9\%) and Adenovirus $(0.9 \%)$. However, the detection methods used would have shown many other viral agents if they had been present. It can be concluded form this study that the viral causes of acute diarrhoea in general practice include Rotavirus as the predominant one, and that this is confined to childhood.

Finally, it appeared from the results of this investigation that children with (acute) diarrhoea do not require routinely to be investigated for worm infestations.

In the final discussion a number of topics in connection with the study method have been described. Firstly, attention is paid to the problem of carrying out investigations in general practice, because not only basic data but also structural provisions are almost always absent. This situation has produced the result that the investigator has himself had to develop all faciliteis for carrying out the project "Acute diarrhoea in general practice" . A summary of these activities is presented as an illustration of this.

In the second instance, there is a general discussion over the restrictions which a study such as this impose upon the investigator because the presence of a microbial agent in the faeces does not becessarily mean that that agent is the cause of the diarrhoea. Also the 
dominant role of the history as a diagnostic tool is compared with the subordinate role of psysical examination. It is also stated that despite the restrictions implicit in the use of a telephone enquiry in a study such as this there is no other practical alternative.

The third part of the discussion contains a numer of recommendations for the general practitioner and are related to his place in the system of health care.

- It is important that the general practitioner checks at the beginning of the history whether the patient with acute diarrhoea and the doctor are using the same terms with the same meanings, and what the normal defaecation pattern is of that particular patient.

- Furthermore, if the general practitioner decides to organise laboratory examination of the faeces, then are the ocurrence of blood in the stools and the presence of fever important factors which really suggest a microbial cause?

- General practitioners have to deceide themselves in the case of children and old people whether (and, if so, to what extent) there is any dehydration.

- A work scheme for the doctors' assistent for dealing with these so-called "minor ailments" in routine practice must be considered as very usefull.

- In orde to prevent spread from an, index case of infectious diarrhoea is is certainly to be recommended in institutions and residential homes, etc., that a central notification office be institued.

- Advice on prevention of cross-infection (such as regular handwashing and cleaning of kitchen equipment) will minimise the danger of spread of infection within the family. Finally, attention is bestowed on the epidemiological aspect of acute diarrhoea. On epidemiological grounds an increase in the number of regional sampling stations, based in rotation on a number of general practices, is recommended. In these sampling stations the families being monitored can contribute to the 
continuity of data collection on micro-organisms circulating in the region. This produces the possibility of sending the general practitioner up-to-date information about the infections in his own district and practice population. 


\section{LITERATUUR BIJ INLEIDING}

1. Hodgkin, $K$.

Towards earlier diagnosis.

Churchill/Livingstone,

Edinburgh, 1985

2. Van der Wielen, $Y$

De huisarts en de doeltreffendheid van zijn aandeel in de gezondheidszorg

Van Gorkum en Comp. WV Assen, 1960

3. Van de Lisdonk, E.

Acute gastro-enteritis

Huisarts en Wetenschap 23, 355, 1980

4. Morrell, D.C.

Huisartsgeneeskunst.

Bewerkt voor Nederland door R.A. de Melker

Bunge, Utrecht, 1984 .

5. Huisman, $\mathrm{J}$.

Enkele epidemiologische aspekten van acute diarree.

Tijdschrift voor Therapie, Geneesmiddelen en onderzoek, $9,213,1984$.

6. Fletcher, R.H.; Fletcher, S.W.; Wagner, E.H.

Clinical epidemiology, the essentials

williams en Wilkens, London, 1982.

7. Velden, H.G.M. van der

Diagnose of pragnose, de betekenis van de epidemiologie voor het handelen van de huisarts

Huisarts en Wetenschap, 26, 125, 1983.

8. Knottnerus, J.A.

Interpretation of diagnostic data:an unexplored field in General Practice

Journal of the Royal College of G.P., 270, 1985

9. Knottnerus, J.A.; Knipschild, P.G.; Sturmans, F.

Symptomatologie en selektiebais. Vertekening van het verband tussen klachten en alagnosen ten gevolge van belektie nar hogere echelons

Huisarts en Wetenschap 28, 325, 1985

10. Barker, D.J.P., en Rose, G

Epidemiology in Medical practice

Churchill/Livingstone, 1979

11. Dupont, H.L. en Pickering, L.K.

Infections of the Gastro-intestinal Tract

Plenum Medical Book Company New York/London, 1980 . 
LITERATUUR BIJ HOORDSTUK 1

1. Barua, D.

Diarrhoea as global problem and the who programme for 1 te control.

In: $T$. Holme a. (red), Acute enteric infections in children. New peospects for treatment and prevention. Elsevier/North-Holland Blomedical Press, 1981.

2. Snyder, J.D., Merson, M.H. The magnitude of the global problem of acute diarrhoeal disease: a review of active survelllance data. Bull. W.H.0. 60, 605, 1982 .

3. Merson, M.H.

The global problem of acute diarrhoeal diseases and the WHO diarrheal disease control programme.

In: Y. Takeda en T. Miwatana (red.), Bacterial Diarrhoeal Diseases

Martinus Nyhoff Publ., 1985.

4. Goldfinger, S.E.

Constipation, diarrhea and disturbances of anorectal functions.

In: E. Braunwald e.a. (red.), Harrison's Principles of Internal Medicine, lle dr., McGraw-Hill Book Comp., 1987.

5. Boydstun, J.S., Barker, J.D., Lawhorne, L. Gastrointestinal disorders

In: R.E. Rakel (red.), Textbook of Family Practice, 3e dr., W.B. Saunders Comp., 1984 .

6. Binder, H.J.

Absorbtion and secretion of water and electrolytes by amall and large intestine.

In: H.V. Sleisenger, J.S. Fordtram (red.), Gastrointestinal disease, 3e dr., W.B. Saunders Comp." 1983.

7. Sinaasappel, M., Bouquet, J. Diarree op de kinderleeftija

Tijdschrift voor Therapie, Geneesmidale en Onderzoek, 9, 240,1984 .

8. Mead, M., Patterson, H.

Diarrhea, P. 47

In: Tutorials in General Practice, Pittman Publ. Ltd. London, 1983.

9. Freyvoge1, T.A.

Durchfälle durch Parasieten

Schweiz. Med. Wschr. 112, 511, 1982. 
10. Bayens, J., van Moer, E.

Defaecatiestoornissen

Wtsch. Uitg. Bunge, Utrecht, 1985.

11. Van der Does, $\mathbf{E}$

Het beleid van de huisarta bij acute diarree

Tijdschrift voor Therapie, Geneesmiddel en onderzoek 9. 218, 1984 .

12. Hodgkin, $K$.

Towards Earlier Diagnosis, 5e dr.. p.489, Churchill Livingstone, Edinburgh, 1985.

13. Huisman, $J$.

Enkele epidemiologische aspecten van acute diarree Tijdschrift voor Therapie, Geneesmiddel en onderzoek, 9, 213,1984

14. Gorbach, S.L. (red.)

Infectious Diarrhea

Blackwell Sc., Publ., Boston, 1986

15. Bock, G., Whelan, J. (red.),

Novel Diarrhoea Viruses

John Wiley, Chicester, 1987.

16. Dupont, H.L., Pickering, L.K.

Relative importance of enteropathogens in acute endemic diarrhea and food-borne diarrheal illness

In: Dupont, H.L., Pickering, L.K. (red.), Infections of the Gastrointestinal Tract. Plenum Med. Book Comp., New York, 1980

17. Dupont, H.L.

Bacterial agents in acute diarrhea

Schwelz. Med. Wochr 112, 15, 1982

18. Carpenter, C.J.

Mechanism of the bacterial diarrheas.

Am. J. Med. 6B, 3, 1980

19. Farmer, $\mathbb{R} . G$.

Infectious diarrhea.

Postgraduate Medicine, 73, 6, 1983.

20. Voorhoeve, H.W.A.

Revolutie in de diarree-behandeling

Medivisie $2,25,1984$. 
21. Huisman, $J$.

Microbiele voedselvergiftiging en voedselinfectie

stafleu, Alphen aan de Rijn, 1980.

22. Beckers, H.J.

Voedselinfecties en -vergiftigingen in Nederland 19771979

Med. T. Geneesk., 125, 2167, 1981

23. Beckers, H.J.

Voedselinfecties en -vergiftigingen in Nederland.

Jaaroverzicht 1970. Veralag Ministerie van WV, staatsuitgeverij. "a Gravenhage, 1983.

24. Snyaham, D.R.

Bacterial Food Polsoning

In: Gorbach, S.L. (red.), Infectious Diarrhea, Blackweel

sci. Publ., Boston, 1986.

25. Schneider, J.

Gastroenteritis due to staphylococcus aureus, clostridium perfringens and bacillus cereus.

In: C.s. Goodwin (red.). Microbes and infections of the gut.

Blackweel sci. Publ., oxfora, 1984

26. Travelers Diarrhea: National Institues of Health Consenous Development Conference. Rev. Infect. Dis. 8 (suppl. 2) $5109-5233,1986$.

27. de Geus, A.

Relzigersairiree

Ned. T. Geneesk., 121, 4, 1977.

28. Marson, M.H.

Prevention of travelers" diarrhea

Gastro-entero1. 84, 424, 1983 .

29. Speelman, P. .

Relziger diarree: oorzaken, profylaxe en behandeling

Ned. T. Geneesk., 131, 801, 1987

30. Dupont, H.L.

Travellers" Diarrhoea

Clin. Res. Rev. 1 (suppl. 1), 225, 1981

31. Gorbach, S.L.

Travelers" Diarrhea

In: Gorbach, S.L. (red.). Infectious Diarrhea

Blackwell Sci. Publ., oxford, 1986 
32. Steffen, $R$.

Epidemiologic studies of Travelers" diarrhea, severe gastro-intestinal infections and cholera

Rev. Infect. Dis. B, S122, 1986

33. MacDonald, K.L, Cohen, M.L.

Epidemiology of Travellers' Diarrhea: Current Perspectives

Rev. Infect. Dis. 8, S117, 1986

34. Ericsson, C.D., Dupont, H.L.

Travellers" dirahea: recent development

In: Remington, J.S., Swartz, M.N. (red.), current clinical topics in infectious diseases, vol. 6 MoGraw-Hill Book Comp. . New York, 1985 .

35. Steffen, R., Rickenbach, M., Wilhelm, U., Helminger, A., Schär, M.

Health problems after travel to developing countries

J. Inf. Dis, 156, 84, 1987.

36. Blaser, J .

Environmental interventions for the prevention for travellers' diarrhea

Rev. Infect. Dis. 8, S142, 1986

37. Sack, R.B.

Antimicrobial prophylaxis of travellers" diarrhea: a selected summary.

Rev. Infect. Dis. 8, Si60, 1986

38. Gross, R.J., Rowe, B.,

Escherichia coli diarrhoea

Int Goodwin, C.s. (red.). Microbes and infections of the gut

Blackweel Sci. Publ.. Oxford, 1984.

39. Guerrant, R.L.

Now Concepts in the pathogenesis of Escherichia coli diarrhea: Introduction

In: Leive, $\mathbb{L}$. (red.), Microblology, 1985

Am. Soc. Microbiol." Wasington $\mathbb{D} . C$. 1985.

40. Levine, M.M.

Escherichia coli that cause diarrhea: enterotoxigenic, enteropathogenic enteroinvasive, enterohemorhagic and enteroadherent.

J. Infect. Dis. 155, 377, 1987

41. Robbins-Browne, R.M.

Traditional enteropathogenic Eacherichia coli of infantile diarrhea

Rev. Infect., Dis. 9, 28, 1987 
42. O'Brien, A.D. Nataro, J.P. New concepte in the pathogenesis of enteropathogenic Escherichia coli diarthea

In: Leive, L. (red.), Microbiology 1985. Am. Soc. Microbiol., Washingtond.C. 1985.

43. Sansonett1, Ph.J.. Hale, T.L., Oaks, E.V. Genetics of virulence in enterolnvasive Escherichia coli In: Leive, L. (red.), Microblology 1985, Am. Soc. Microbiol.. Washongton D.C., 1985

44. Dupont, H.L., Pickering, L.K.

Infections of the gastrointestinal tract. Plenum Med. Books Comp., New York, 1980

45. Gorbach, S.L. (red.),

Infectious diarrhea

Blackwell sci. Publ., Oxford, 1986

46. Ryser, R.J., Hornick, R.B.

A review of "new" bacterial strains causing diarrhea

In: Remmington, J.5., Swartz, M.N. (red.), current clinical topic in infectious diseases, vol. 2, McGraw-Hill Book Comp., New York, 1981

47. Edel, W.. Guinee, P.A.M., van schothorst, M. e.a. salmonelia cyclus in food with special reference to the effects of environmental factors

Can. Inst, Food Sci. Technol. 6, 64, 1973.

48. Huisman, J.. Leroy, J.J.

Salmonellae, slagers en slagerijen

Ned. T. Geneesk., 21, B, 1977

49. Palmer, S.R., Jephcott, A.E., Rasland, A.J.

Person to person spread of Salmonellae typhimurium phagetype 10 after a common course outbreak.

Lancet 1, 881,1981

50. van Schothorat, M.. Hulisman, J., van Os, M. salmonella-onderzoek in huishoudens met balmonellose bij zuigelingen

Ned. I. Geneesk., 122, 1121, 1978

51. Danie1., A.J.M.

Onderzoek naar Enterovirussen, Salmonellae en shígellae in gezinnen met jonge kinderen. Proefichrift, Amsterdam, 1966.

52. Schilder, A.J., Thompson, J., Mouton, R.P. Een geval van salmonella-enterocolitis

Ned. T. Geneesk., 126, 21, 1983 
53. Pennington, C.R., Bickeratoff, K.I., Lyall, M.H. Salmonella infection with colitis

J. Infect. , 2, 181, 1980

54. Hyams, J.S., Durbin, W.A., Grand, R.J. salmonella bacteriaemie in the first year of life J. Paediatr., 96, 57, 1980

55. Zuidema, P.J.

Shigellosis

Ned. T. Geneesk., 123, 16, 1979

56. de Be11, E.E., Shigellose in Amsterdam 1976-1983

Afd. Volksgezondheid, GG en GD Amsterdam, 1985

57. Butzler, J.P., Dekeyser, P., Detrain, F. Related vibrio in stools

J. Pediatr., 82, 493, 1973

58. Skirrow, M.B.

Campylobacter enterititig: new diseage

Br. Med. J., 2, 9, 1977.

59. Newel, D.G. (red.)

Campylobacter: epidemiology, pathogenesis and biochemistry

MTP Press Ltd., Lancaster, 1982

60. Severin, W.P.J.

Campylobacter en enteritis

Ned. T. Geneesk., 122, 15, 1978

61. Oosterom, J.

Infectie met campylobacter fetus subspecies jejuni; overzicht van de literatuur en beepreking, van de epidemiologiache aspekten

Ned. T. Geneesk., 124, 39, 1980

62. Oosterom, J.

Studies on the epidemiology of Campylobacter jejuni

Proefschrift, Rotterdam, 1985.

63. Oosterom, J.

Infecties met Campylobacter jejuni: epidemiologie en eventuele preventie

Ned. T. Geneesk., 129, 2100, 1985

64. Kendall, E.J.C., Tanner, E.J.

Campylobacter enteritis in general practice

J. Hyg. Camb. $88,155,1982$

65. Snyaham, D.R.

Campylobacter gastroenteritis

Am. Fam. Physician, januari 1982 
66. Nachertgaele, H., Claeys, G., Verschraeghen, 6.. Lambrecht, L., Clement, D. Infecties veroorzakt door Campylobacter fetus. Ned. T. Geneesk. 131, 320, 1987

67. Ho11, H., de Boer, E., Stigter, H.H. Campylobacter enterocolitis na consumptie van kip Ned. T. Geneesk., 126, 21, 1982

68. Es aeveld, M., Goudzwarar, C.

On the epidemiology of $Y$. enterocolitica infections: pigs as the source of infections in man.

Proe. Intern. Symp. on Yersinia, Pasteurella and Francicella

Malmö, 1972

69. Lang ford, E.V.

Yersinia enterocolitica isolated from animals in the Fraser Valley of British collumbia

Can. Vet. J.. 13, 104, 1972

70. Lassen, $J$.

Yersinia enterocolitica in arinking water.

scand. J. Infect.. Dis. 4, 125, 1972

71. Black, R.E., Jackson, R.J., Tai, T. e.a.

Yersinia enterocolitica infection due to contamined chocolate milk.

N. Engl. J. Med., 298, 76, 1978

72. Vantrappen, G.. e.a.

Yer inia enteritis en enterocolitis: gastro-enterological aspects.

Gastro-enterol, , 72, 220, 1977

73. Sari, T.N., Triplett, D.A;

Yersinia pseudotubercolosis mesenteric adenitis

J. Pediatr., $85,656,1974$.

74. Kohl, S., Jacobson, J.A. Nahmias, A. Yerainia enterocolitica infections in children

J. Pediatr. " $89,77,1976$

75. Dequeker, J., Jamar, R., Walravens, M. HIA-B27. Arthritis and Yersinia enterocolitica infection J. Rheumatol., 7, 706, 1980

76. Olgon, D.N., Finck, W.R.

Reactive arthritis associated with Yersinia enterocolitica gastroenteritis

Am. J. Gastroenterol., 76, 525, 1981

77. Wolf, J.L.

Infectious diarrhea

Patient Care, no. 15, 1983 
78. Pascal., A., Blacklow, N.R..

In: Gorbach, S.L. (red.), Infectious Diarrhea, Blackwell Sci. Publ., Boston, 1986

79. Cukor, G.. Blcklow, N.R.

Human viral gastroenteritis

Microbiol. Review, 48, 157, 1984

80. Schaap, G.J.P.. Dumas, A.M., Buitenwerf, J.

Een decennium onderzoek naar virale gastroenteritis bij jonge kinderen

Ned. T. Geneesk., 129, 395, 1985

81. Wenman, W.M., Hinde, D., Feltham, 5., Gurwith, M. Rotavirus infection in adults: result of a prospective family study

N. Engl. J. Med.. 303, 1979

82. Foster, S.0., Palmer, E.L. e.a.

Gastroenteritis due to rotavirus in an isolated Pacific Island Group: an epidemic of 3.439 cases.

J. Infect. Dis. 141, 32, 1980

83. Hardy, D.B.

Epidemiology of rotaviral infections in adults

Rev. Infect. Dis.., 9, 461, 1987

84. Gurwith, M., Wennan, D., e.a.

Diarrhea among infants and young children in Canada: a longitudinal study in three northern communities.

$\mathrm{J}$. Infect, Dis., 147,685, 1983

85. Vesikari, T., Isolauri, E., Ruuska, T., Rautanen, T. Clinical trials of rotavirus vaceins

In: Bock, G., Whelan, J. (red.). Novel diarrhoea viruses, wiley, Chicester, 1987.

8.6. Hanlon, P., Marsh, V. e.a.

Trial of an attenuated bovine rotavirus vaccin (RIT 4237) in Gambian Infants.

Lancet 1, 1342, 1987

87. Bridger, J.C.

Novel rotaviruses in animals and man.

In: Bock, G., Whelan, J. (red.), Novel diarrhoea viruses, wiley, Chicester, 1987

88. Greenberg, H.B., Valdesuso, J.R. e.a.

Prevalence of antibody to the Norwalk virus in various countries

Infect. Immun. , 26, 270, 1979

89. Uhnoo, I., Wadell, G., Svension, L. e.a.

Two new erotypes of enteric adenovirus causing infantile diarrhoea.

Dev. Biol. Stand., 53, 311, 1983. 
90. Brandt, C.D., Kim, H.W.. Rodriguez, J. e.a. Pediatric viral gastroenteritis during eight yeara of etudy J. Clin. Mierobiol., 318, 71, 1983

91. Flewett, T.H., Davies, H.

Callclvirus in man

Lancet $1,311,1976$

92. Kurtz, J.B., Lee, T.W., Graig, J.W; e.a. Astrovirus infection in volunters

J. Med. Virol., 3, 221, 1979

93. Tzipor1, s.,

Cryptosporidiosis in animals and humans Microb. Rev., 47, 84, 1983

94. Soave, R., Danner, R.L., Honig, C.L. e.a. Cryptosporidiosil in homosexual man.

Ann. Internal Med. $100,504,1984$

95. Mavin, T.R., Janurak, D.D.

Cryptosporidiosis: clinical, epidemiologic and parasitologic review

Rev. Infect. Dis., 6, 313, 1984

96. Koch, K.L., Phillips, D.L., Arber, R.C. e.a.

Cryptosporidiosis in hospital personnel. Evidence for person-to-peraon transmission.

Ann. Intern. Med., 102, 593, 1985

97. D'Antonio, R.G., Winn, R.E., Taylor, J.P. e.a.

A waterborne outbreak of cryptosporidiosis in normal hoots.

Ann. Intern. Med., 103, 886, 1985.

98. Soave, R., Ma, P.,

Cryptosporidiosis: travelers' diarrhea in two families.

Arch. Intern. MEd., 145, 78, 1985 .

99. Editorial. Cryptosporidiosis.

Eur. J. Clin. Microbiol. 5, 135, 1987

100.Casemore, D.P.. Jackson, B.

Sporadic cryptosporidiosis in children.

Lancet $2,679,1983$. 
1. Hodgkin, K.

Towards earlier diagnosis

Churchill/Livingstone

Bdinburgh, 1985

2. Daniels, A.J.H..

De patient met diarree

Kompas van de Huisarts, 1977, Scheltema en Holkema

3. de Melker, R.A.

Gezinsinfekties

The Practitioner, 593, 1984

4. v.d. Lisdonk, E.H.

Acute gastro-enteritis

Huisarts en Wetenschap 23, 355, 1980

5. Hennink, M.P.

Het beleid van de huisarts bij patienten met defaecatiestoornissen

Huisarts en Praktijk 3 uitgave van Huisarts en Wetenschap, 9, 1978

6. Satterwhite, T.K., Dupont, H.L.

Infectious diarrhea in officie Pratice

Med. Clin. of North America, 67, 1, 1983

7. Wolf, J.L.

Infectious diarrhea? What' the cause?

Patient Care, no. 15, 1983

B. Dees, J.

Analyse van diarree

Tijdschrift voor Therapie, Geneesmiddel en Onderzoek, 9, 235, 1984

9. Skirrow, M.B.; Turnbull, G.L., Halker, R.E. et al

Campylobacter jejuni enteritis transmitted from cat to man

Lancet 31,1980

10. Eygrond, B.D.P., Coutinho, R.A.

Aids en de eerste lijn

Tijaschrift voor Therapie, Geneesmidale en onderzoek, 11,7, 1986

11. v.a. Does, E.

Het beleid van de huisats bij acute diarree

Tijdschrift voor Therapie, Geneesmiddel en onderzoek, 9, 218, 1984

12. Koplan, J.P., Fineberg, H.V., Rosenberg, M.L. Value of stool cultures

Lancet, 413,1980 
13. G111, K.

Defaecaties van de mens

Hulsarts en Wetenschap, $22,186,1979$

14. Rapkin, R.H.

Acute infectious gastro-enteritis

Recent advances pertinent to primary care practice

J. of med. soc. of New Yersey, 73, 2, 1976

15. Donowitz, M, Wicks, J., Sharp, G.W.G.

Drug therapy for diarrheal diseases: a look ahead

Reviews of infectious diseases, 8, 2, 1986

16. Santosham, M. , Daum, R.S., Dillman, L. et al

oral rehydration Therapy of Infantile Diarrhea: a controlled atudy of well-nourished children hospitalized in United States and Panam

The New Engl. J, of Med., 306, 18, 1070, 1982

17. Voorhoeve, H.W.A.

Revoluties in de diarree behandeling (anno 1980)

Medevisie 2, 3, 1984

18. Fliers, E.A., Ymtema, J.L.

Een voorbeeld van verkeerde zuinigheid

wed. T. v. Geneesk., 128, 47, 1984

19. Matti, H.

Farmacologie van middelen tegen diarree

Tijdachrift voor Theraple, Geneesmiddelen en onderzoek, 9, $24 \mathrm{~B}, 1984$

20. van der Meer J.W.M., Lamers, C.B.H.W. Middelen tegen diarree

Ned. T. v. Geneesk., 131, 12, 1987

21. Dupont, H.L., sulilvan, P.. Plckering, L.K. et al

symptomatic treatment of diarrhoea with Besmuth subsalicylate among tudents attending a Mexican university

Gatro-enterology, 73, 715, 1977

22. Pickering, L.K.

Anti-imicrobiol. Therapy of Gastointestinal infection

Pedeatric clinics of North America, 30, 1983

23. Noordhoek, Hegt, P.J.F., Bastemeijer, J.

Behandeling van acute diarree en vergiftigingen met actieve kool

Medevisie, 1984

24. Ewe, K.

Aktuelle Therapie, Therapie der akuten incetiosen Diarrhoe

Dtsch. Med. Wschr.. 108, 989, 1983

25. Murray, B.E.

Resistance of Shigella, Salmonella and other selected enteric pathogens to antimicrobial agents

Reviews of infectious diseases, 8, 2, 1986 
26. Nelson, J.D., Kusemiesz, H., Jackson, L.H.

Treatment of Salmonella Gastroenteritis with Ampicillin. Amoxicilin or Placebo

Pediatrics, 65, 6, 1125, 1980

27. Asherhoff, B., Bennett, J.V.

Effects of antibiotic therapy in acute salmonellosis on the fecal excretion of Salmonella

New Engl. J. Med., 281, 634, 1969

28. Nye, F.J.

Do antibiotics really prolong salmonella excretion

J. of Antimicrobiol. Chemotherapy, 7, 215, 1981

29. Hennessy, W.B.

Travelers diarrhoea: a review

Australian Family Physician, march, 1981

30. Sherwood, L., Gorbach, Edelman, R. ed

Travelers' aiarrhea: national institues of health consensus development conference

Reviews of Infectious Diseases, 8, 2. 1986

31. Geloof, H., Tytgat, G.N.

Beleid van de huisart bij volwassenen met acute diarree

Modern Medicine, 1279,1986

LITERATUUR BIJ HOOFDSTUK 3

1. Huisman, J.

Enkele epidemiologische apekten van acute diarree

Tijaschrift voor Therapie, Geneesmiddel en Onderzoek, 9, 213, 1984

2. Baumgarten, R., Pengler J.D.

Diarrhoeische Erkrankungen durch Darminfektionen

L. Aerztl. Fortbild. 76, 951, 1982

3. Hennink, M.P.

Het beleid van de huisarts bij patienten met defaecatiestoornissen

Huisarts en Praktijk (3), uitgave Huisarts en Wetenschap, 9 , 1978

4. Chaddwick, V.S.

Diarree is alleen funktioneel als alle onderzoek normal is Madern Medicine, 766,1981

5. Krupp en Chatton

Diagnose en Therapie

Kooyker, 1983 
6. Sinaasappel, M., Bouquet, $J$. Diarree op de kinderleeftija Tijdschrift voor Theraple, Geneesmiddel en Onderzoek, 9, 241, 1984

7. Wouters, F.A., Miemegeers, C.J.E., Messchendorp, H. De farmakologie van anti-diarrhoica

Tijdschrift voor Therapie, Geneesmiddel en Onderzoek, 9, 251, 1984

B. Stals, F., Walther, F.J., Bruggeman, C.A.

Faecal and pharyngeal shedding of rotavirus and rotavirus IgA in children with diarrhoea

J. of Med. Virology 14, 333, 1984

LITERATUUR BIJ HOOFDSTUK 5

1. Jewke日, J. Larsen, H.E., Price, A.B. et al

Aetiology of acute diarrhoe in adults

Gut, 22, 388, 1981

2. Truant, A.L., Chonmaitree,T.T.

Incidence of Rotavirus Infection in Different age groups of paediatric patients with gastro-enteritis

J. of Clinical Microbiology, 16(3), 558, 1982

3. Taminiau, J.A.J.M.

Acute gastro-enteritio bij kinderen: pathofysiologie en behandeling

Ned. T. v. Geneesk., 128, 47, 1984

4. Huisman, J.

Microbiule voedselvergiftiging en voedselinfectie

stafleu, Alphen aan de Rijn, 1980

5. Aquiar, A, Ribeiro, T., Santos, N. et al

Infectious tiology of acute diarree in childhood

International Congress of gastro-enterology XII

Lis sabon/Portugal, 1984

6. Marka, M.J., Pai, C.H., La Fleur, L. et al

Yersinia enterocolitica gastro-enteritis: a prospective study of clinical, bacteriological and epidemiological features Journal of Pediatrics, $96(1), 26,1980$

7. Morris, G.K., Feeley, J.C.

Yersinia enterocolitica: a review of its role in food hygienics

Bull. World Health Organisation, 54, 79, 1976

8. Toma, S., Lafleur, L.

Survey on the incidence of yersinia enterocolitica infections in Canada

App1. Microbiology, 28(3), 469, 1974 
9. Bänfer, J.R.J., Severin, W.P.J.

De betekenis van Campylobacter jejuni als verwekker van gastro-enteritis in Nederland

Wed. $T$. V. Geneesk. 126, 21, 1982

10. Drake, A.a., Gilchrist, H.J.R., Washington, J.A. et al Diarrhoea due to campylobacter jejuni subspecies jejuni Moyo clinic press $56(7), 414,1981$

11. Manual of clinical laboratory immunology American society for microbiology

Ea. Rose, N.R., Friedman, H., Fahey, J.L.

"Thira edition, 1986

12. Mazurkiewicz, E., Tordoir, B.T. Baciliaire dysenterie in Utrecht, twee epidemieón Med. T. V. Geneesk., 129, 895, 1985

LITERATUUR BIJ HOOFDSTUK 6

1. Sinaasappe 1, M. , Bouget, J.

Diarree op de kinderleeftija

TGO Tijdschrift voor Therapie, Geneesmiddel en Onderzoek, 9 , 241,1984

2. Mazurkiewicz, E., Tordoir, B.T.

Bacillaire dysenterie in Utrecht, twee epidemieën

Ned. T. V. Geneesk., 129, 895, 1985

3. Weinstein, M.C., Fineberg, H.V.

Clinical Decision Analysis

Saunders Philadelphia, 1980

4. Knottnerus, J.A.

Interpretatie van diagnostische gegevens

Dissertatie, Mastricht, 1986

5. Sturmans, $\mathbf{F}$.

Evaluatie van het diagnostisch proces

Medische Besliskunde, 4e druk, oktober 1985

Uitgave Rijksuniversiteit Limburg (Buro Post Academisch Onderwijs Geneeskunde)

6. Nie, N.H.e.a.

S.P.S.S.: Statistic Package Soclal Sciences, second edition. hoofdstuk over stepwise regression, 1975

7. Sips, A.J.B.I.

Protokollen voor de huisarts

Medisch Contact, 9, 277, 1986

B. Eigen onderzoek, zie hoofdstuk 2.2 
9. Gajaf, H., Tijtgat, G.M.

Beleid van de huisarte bij volwassenen met acute diarree Modern Medicine, 1279, 1986

10. Voge 1, N.F.

Enteritis reglonalis

Nea. T. v. Geneesk., 13,430, 1978

11. Prinsen, J.E.

Defaecatiestoornisen bij kinderen.

Huisarto en Praktijk (3), uitgave Hulearts en Wetenschap, 27, 1979 


\section{BEOUETEPORAMUIER PROTEKT "ADIP"}

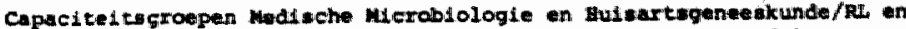

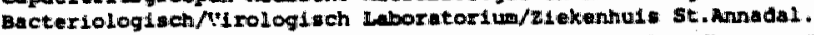

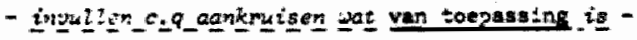
Datun
Naam oatient:

\section{Noorletters.}

kind: roepneam

Adres

Ceb. datum

Gemente

Gesidacht : $\operatorname{man} 1$ Wr1

Naari huisarts

Naveri artis-ass :
Ingerturird voor onderzoek: 1e 2e monstex

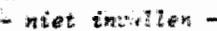

prakt jyknr.

datum fname

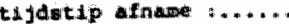

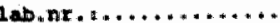

datum Laset kweek

tylstip Inzet

kweek $7, \ldots \ldots \ldots \ldots \ldots \ldots *$

Betrert het appel van die patjent een :

consult ; $[$ (zo ja, hoeveelste mbt deze wlacht in deze zlekteperiode: ..... (cetai)

visite $: \square$ " $"$ "

tel.overleg: met huisarts met artis-ass. met dokteriass.

overleg aan de recieptiebalie v.d. praktijk: met hudiarts met arte-abis met doktersas!

ANAMNESE Proble(elmien) - in ejper bewoordingen van pat ient notemen -

GEGEVENS of klacht (en):

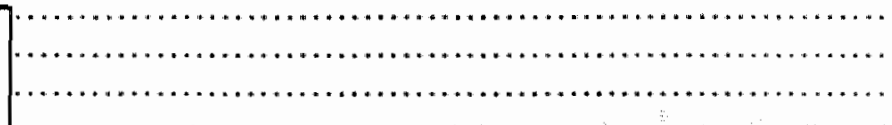

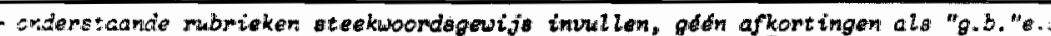
Beves: igend/antkennenc artwoond vam matient aangeven met $\Theta / O$ achtor item.

Aanvull lende vragen/

is ens door huisarts

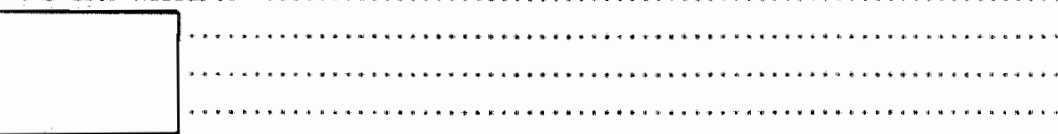

Andere bijtethorende

de klechten.

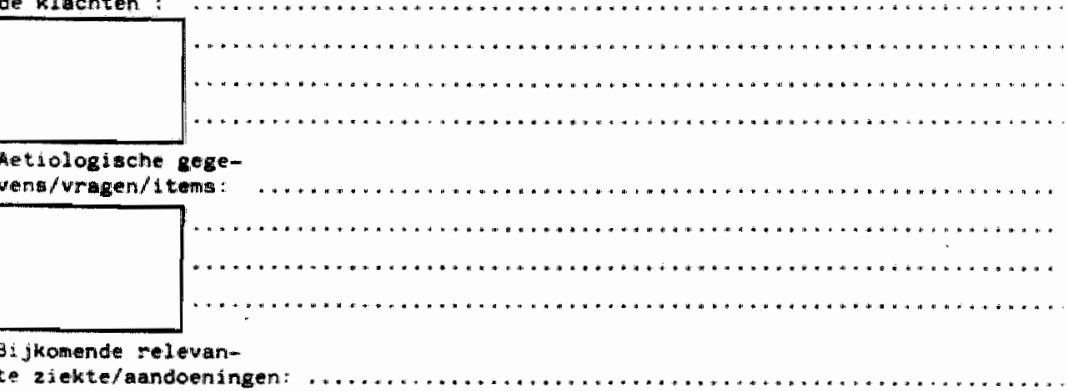

levan- 


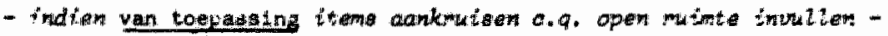

\begin{tabular}{|c|c|}
\hline \multirow[t]{3}{*}{$\begin{array}{l}\text { OKDERZZOEKS } \\
\text { GEGEVENS }\end{array}$} & 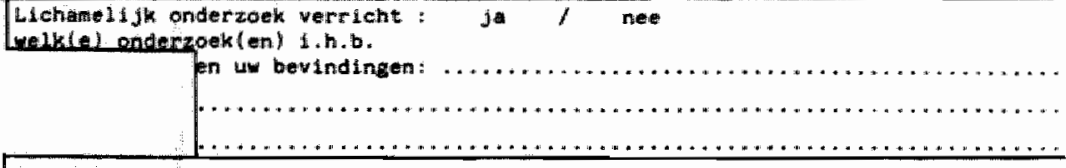 \\
\hline & 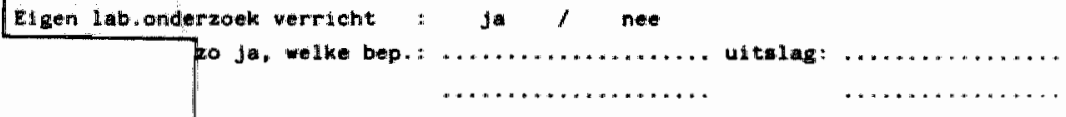 \\
\hline & 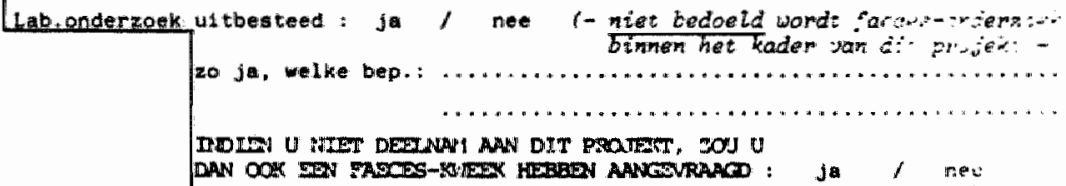 \\
\hline \multirow[t]{3}{*}{ EVALUATIE } & 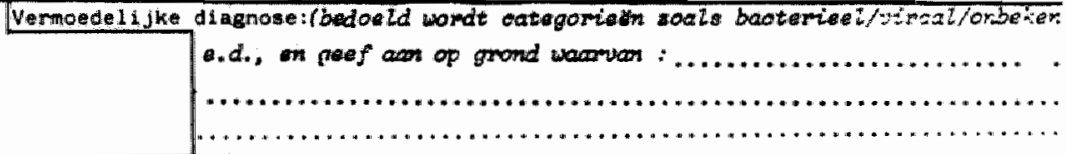 \\
\hline & 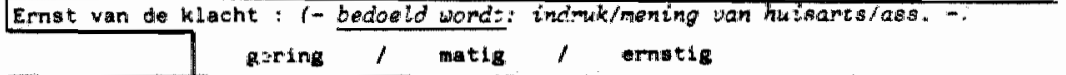 \\
\hline & 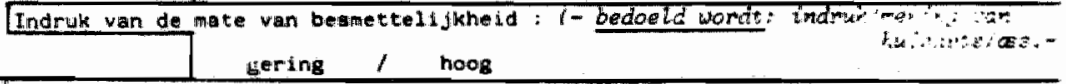 \\
\hline \multirow[t]{6}{*}{ PLAN } & 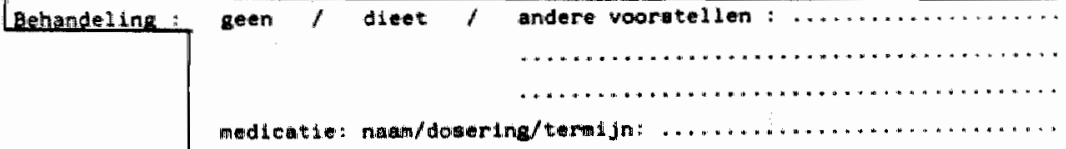 \\
\hline & 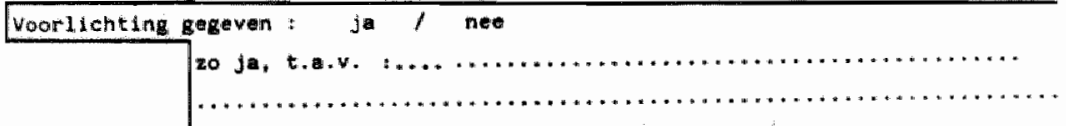 \\
\hline & Controle-arspriake : \\
\hline & Verwidung: \\
\hline & Indien $\mathrm{y}_{\text {* }}$ welk speciallame : $\ldots .$. \\
\hline & $\begin{array}{l}\text { ja } \quad / \text { nee } \\
\text { Indien ja welk specialliame : } \ldots \ldots \ldots \ldots \ldots \ldots \ldots \ldots\end{array}$ \\
\hline
\end{tabular}




\section{ENQUETESORUULIER PROAECT MDIP"}

Capuciteftsgroepen Nedische Microblologle en Hulsartsgiemeeskunde/al en

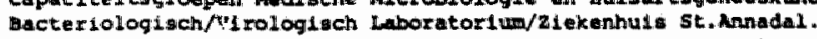

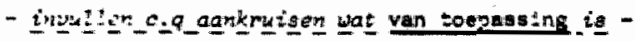

\section{Dat,ib-}

\section{Nagristont:}

\section{Adriens}

Geb. datum

Naar: 7is sarts

Naan arta-ass.

\section{Voorlletters: \\ kind: roepnaan :}

cremeentie:

Geslacht : $\operatorname{minl}$ wrl

\section{Ingestuurd woor}

onderzoek: He 2e momer

Betreft he: appel wan je patient sen:

- niet imingltion

prakelftemr. : ..........

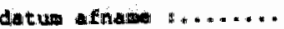

tijdstip afname : $\ldots$...

labn $n x, \ldots \ldots \ldots \ldots$

datum foret kweek

\section{Jdstip intote}

kwek

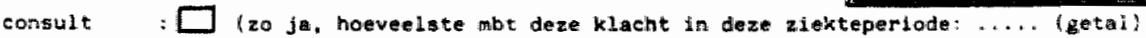

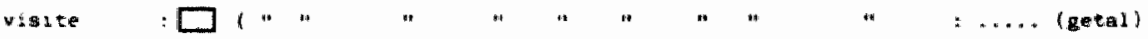

tel. overleg: met huisartis met arts-asss met doktrerass.

overlef san de receptiebalie v.d. praktijk: met huldarts. met artis-asis. met doktersais"

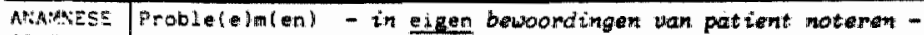

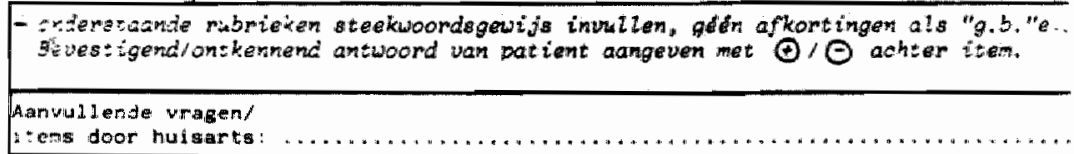

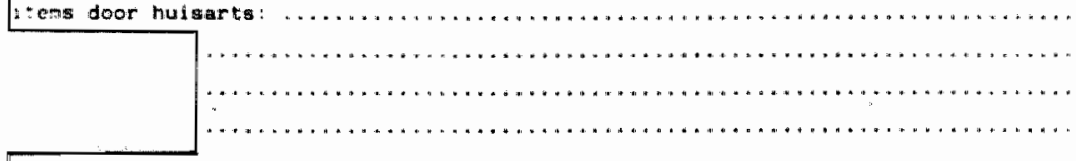

Andere bijbehorende de klachten

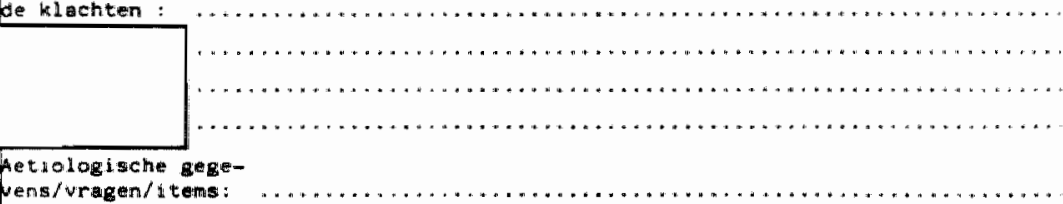




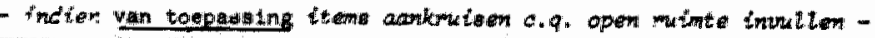

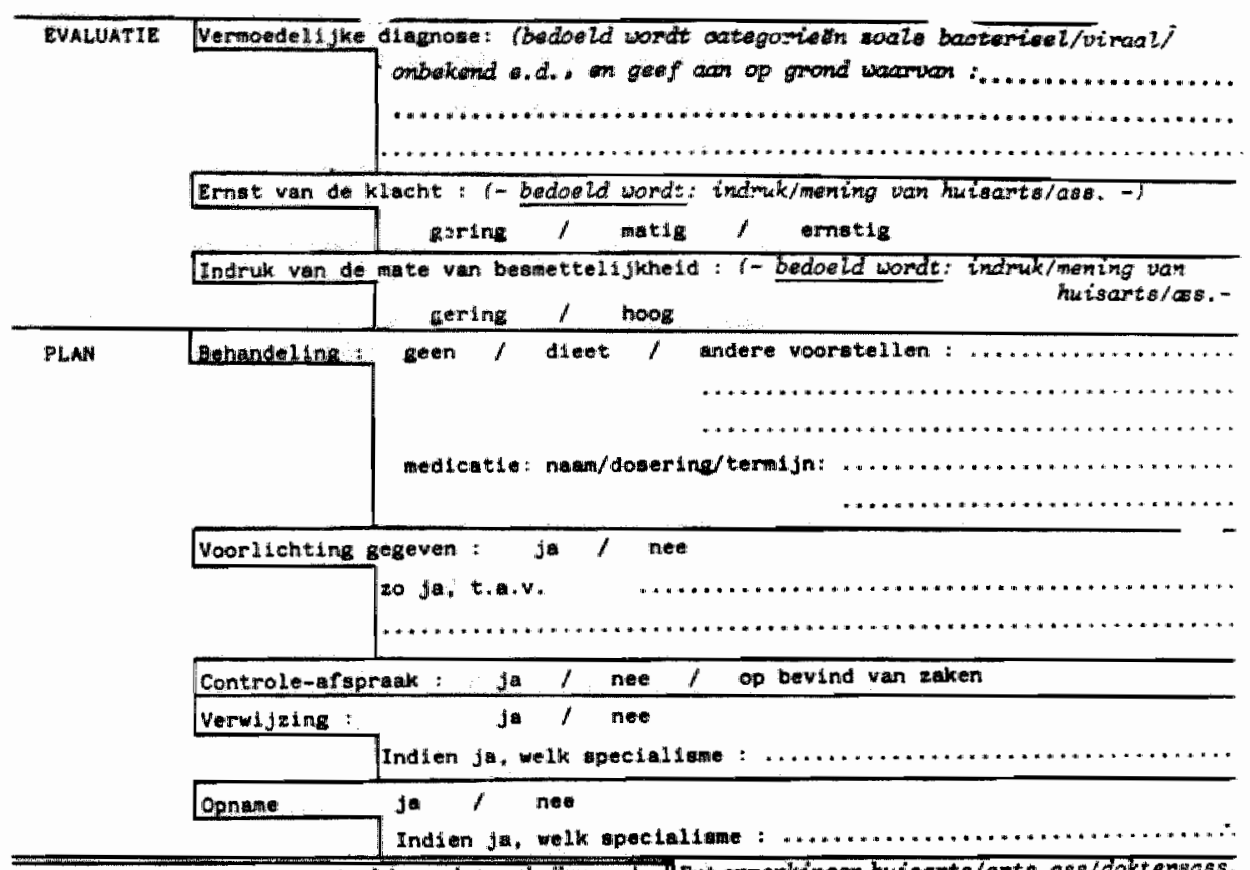

Lab.uites lag:

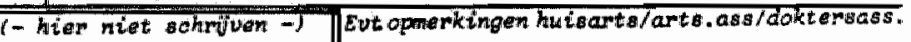




\section{Vragen telefonische enquatte Follow-up onderzoek}

\section{Instruktile an de enqueteur:}

U spreekt met ...... van de R.L. .

Mevrouw/meneer, het gat over het onserzoek naar diarree, waraan uw hularts meedoet.

Wellicht heeft wh huisarts $u$ verteld, dat $u$ ma ongeveer een week nog opgebeld zow kumnen worden door lemamd van de univeraitelt on te vragen hoe de klacht verlopen 18 . Antwoord'?

Ik zal $u$ uitleggen wat de bedoeling is. Ik ga in 5 kleine groepen een aantal vragen stellen die aliemal te maken hebben met de klacht diarree.

Het eergte groepjo vragen gat over de periade voordat u naar de huisarts ging of met de doktersassistente sprak (noteren wanneer dit was en met wite gesproken is $)$.

\section{Blok 1:}

- hoeveel dagen had $u$ al diarree voordat u kontakt opmam met die praktijk? (of voordat u naar de huisiarts ging?)

(Bamen met patient dagen tellen!)

- hoeveel keer moest u per dag naar het tollet voor de ontlasting?

- wat was de vom van de ontlasting (soms moet een voorbeeld gegeven worden, b.w. waterdun, brijig, pappig etc.)

- wat voor kleur had de ontlasting?

- wat vaor geur (reuk) had de ontlasting? (gom moet een voorbeeld gegeven worden " b.v. stinkend, rottend, etc..)

- zat er ook bloed bij de ontlasting? indien ja: hoveel dagen heeft u nu in totalal bloed bij de ontlasting gezien? (samen tellen)

- zat er sijm bij de ontlasting? Indien ja: hoeverl dagen heeft $u$ in totaal ilijm bij de ontlasting gezien? (samen tellem)

- was u or ook misselijk olj? indien ja: hoe lang bent $u$ nit in het totaal misselijk gewerst? (samen tellen)

- had u voordat u near de hulsarts ging (or kontakt had met de praktijk) ook last van braken? Indien jis: hoeveel dagen theeft $u$ er nu in totaal last van gehad?

- had u to die tijld ook last van buikkrampen of buikpijn? indien ja:

hoevel dagen heeft deze klacht in totaal bestaan?

- had u ook last van koorts in die periode (or en koortaib gevoel?) indien ja: heeft u de temperatuur ook mog opgenemen. $z_{0} \mathrm{ja}$ : hoe hoog was dile?

- voelde u zich ex echt ziek van in dile tijd?

- had u ook last van hoofdpijn, ik bedoel erger dan we allemal wel eens hebben lis we ons niet lekker woelen?

- had u nog andere klachten in die pertode dile u bljzonder zijn opgow vallen?

\section{Blok 2:}

\section{Ingtruktie:}

Het volgende blokje vragen gaat over het kontakt met de praktlijk.

- heeft uw huisarts (doktersabsistente) w een adules gegevem?

- ging dat over eien dieet? (Meeft u samen gesproken over wat je wel of beter niet kon eten?)

- heeft de huisarts $u$ een geneesimiddel voorgeschreven? indien jia: weet w nog hore dat middel heet (soms laten spellen wat or op het (llesje staat).

- hoelang heeft $u$ dit medicijn gebruikt? (amen het antal tabletten of druppels dag woor dag tellen) 
- heert u zelf nu nog medtcijnen gebrulkt, ik bedoel dusi midielen die niet van de hularta heeft gekregen? Indfen je: navm van de middelen notimen.

- heert Lw huleartio u nog andere dviezen gegewens behoudens medicijn of dieet?

\section{Blok 3:}

Inetruktie:

Het wolgem groepje vragen gat over het moment, dat de diarree over gaat (of misgichlen werd thet wel slechter).

Simen tellem van de dag ven het kantakt met de praktijk.

- na hoeveel dagen ging de klacht (diarree) over?

- is ook en periode na het kontakt met de praktijk gewest dat u meer dan twee dagen hel maal geen ontlasting heeft gehad?

\section{Bllok 4i:}

\section{Instruktie:}

Het schlet al lekker op. De volgende vragen gaan over dit moment dat wif - likaar an de telefoon hebben. Dug over hoe het nu met u gat en ik u wen bekend rijtje vragen stellen:

- heert u nog diarree?

- hoe valk gaat u nu maar het toilet voor de ontlasting?

- hoe is de vorm van de ontlasting?

- wat voor ' $n$ klewr heeft die ontlasting?

- wat voor geur of reuk heeft de ontlasting?

- zilt er nu bloed bij?

- zit er nil siljm bij?

- heeft u lasit van braken?

- heeft $u$ last van buikkrampen of buikpijn?

- heeft u last van koorts of hoortsig gevoel?

- voelt u zich nu ziek?

- heeft u nu last wan erge hoofdpijn (meer dan nomaal)?

- heeft $u$ nu andere kilachten?

\section{Blok 5:}

\section{Inde trukt te:}

Nu volgt het laste rijtje. De volgende uragen gan ower milleritel onderwerpen.

Heeft uw hisarta $u$ nog wat uitgelegd of verteld over de klacht? Ik ga cen par voorbeldien geven marover u gesproken zou kunnen hebben:

- 1. or met u gesproken over hyglene (handen wassen e.d.)?

- Le er met u gesproken over dat de klacht misschien wel besmettelljk kan zily? (over het felt dat $u$ het wer anderen kan doorgeven of dat w het misschlien van anderen gekrigen kan hebben)

- io er met $u$ geaproken of u met $20, \mathrm{n}$ klacht toch kan gaan werken? (huishouden, school)

- houdt u nog diet? indlen nee: hoelang heeft $u$ inu echt dleet gehouden? (dagen amen tellen)

- gebrulkt u nu nog medlcijnen? indien nee: bent: u gestopt ondat de klacht over (minder) was of omdat de medicljmen op waren?

- heeft $u$ de medicljinen goed verdragen? Indien mee: wat waren dan de klachten?

- bent u blijven werken? (huighouden "school, voor gepensioneerden het gewone gangetjel. Indlen noe: hovveel dagen bent $u$ nu echt zlek geweest, ik bedoel zodanis dat u vrijwel niete anders kon doen?

- heeft w op dit moment nog andere klachten?

- Ler met u nog iets afgespraken of $y$ nog moet terugkomen of moet bellen voor de uitslag? 
- hoeveel maal heeft u kontakt gehad met de praktijlik voor deze klacht? (nateren in ...Monsulten; ...visites; ...telefoon; ...receptie/balie)

- In de perfode dat u diarmee heeft gehad, en rekent u de perlode maar zeer ruim van cen week voordat wi met de klachten begon tot aan vandaag. waren er nog andere personen in uw gezin. die ook diarree haddem? Zo ja: vragen wile : volwassenen, hinderen (allen boven de 10 jaar vorden als volwassene gerekend).

- mag ik de samensteling van uw gezin weten. ik bedoel ust hooveel personem bestat uw gezin? (noteren in symbolen, inklusief leoftijden).

Mog een pasar llerlatiste vragen:

- wait denkt u zelf diat de oorzakk wan de diarree kan zijn?

- had u taevallig lets gegeten (b. $v$. barbecuevlees of kip) of gedronken wat is niet vertrouwde?

- wat was woor u de reden die u deed besiluten de huisartis in te schakelem of m.a.w. waarom zel u tegen uzelf: mar mu achakel ik de huisarts in?

- is er lemand in het gezin in uw echtgenoot of een van de kinderen, ale in aijn werk iets te maken heeft met het klaarmaken of verpakken van eetof drinkwaren? (1k bedoel niet het hulahoudel1jk werk)

Dit waren alle vragen. Mag $1 k$ u hartelijk danken voor uw medewerking aan dit onderzoek.

Insitruktie:

Er wordt geen informatle gogeven aver de ultilag noch enig kommentarar gegeven

op de handelwijze van de huisarts.

De patient wordt voor vragen terugverwezen naer de hufisarts. 


\begin{tabular}{|c|c|c|c|}
\hline 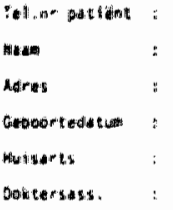 & & 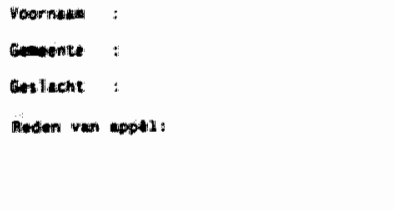 & 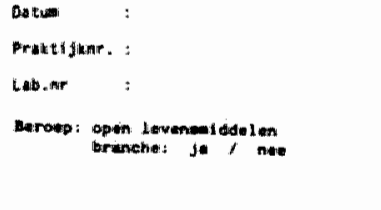 \\
\hline 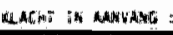 & & 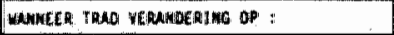 & 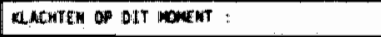 \\
\hline 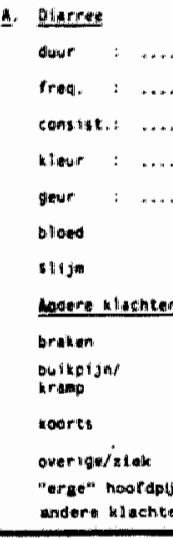 & 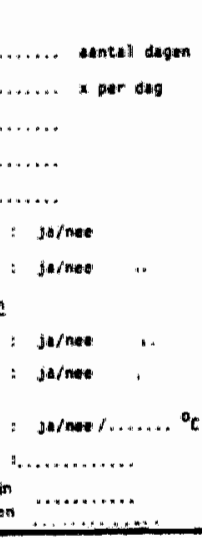 & 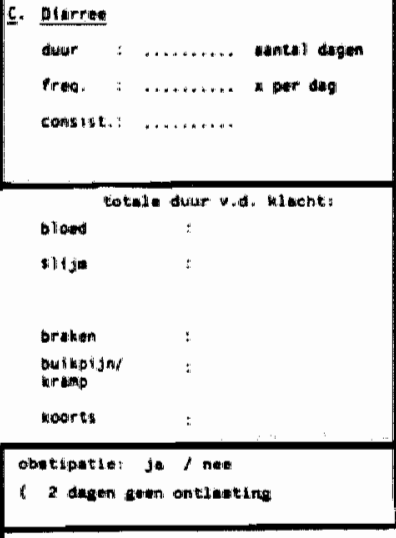 & 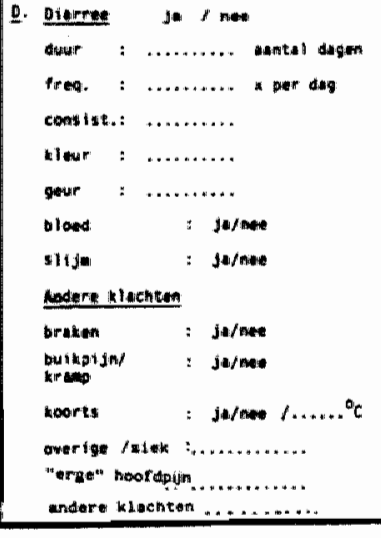 \\
\hline Dethoct ing : & & orcaice: & \\
\hline 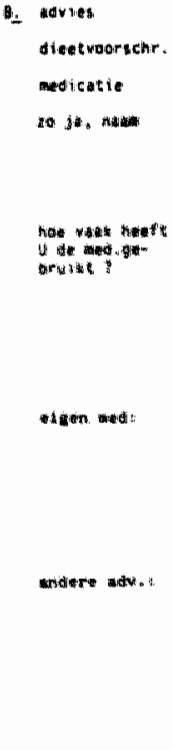 & 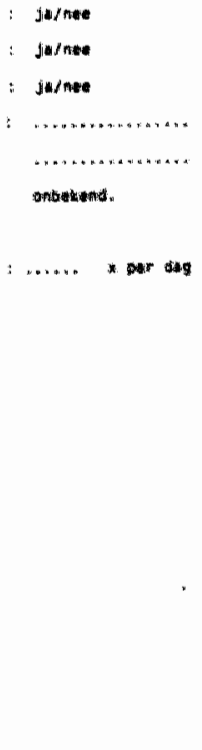 & 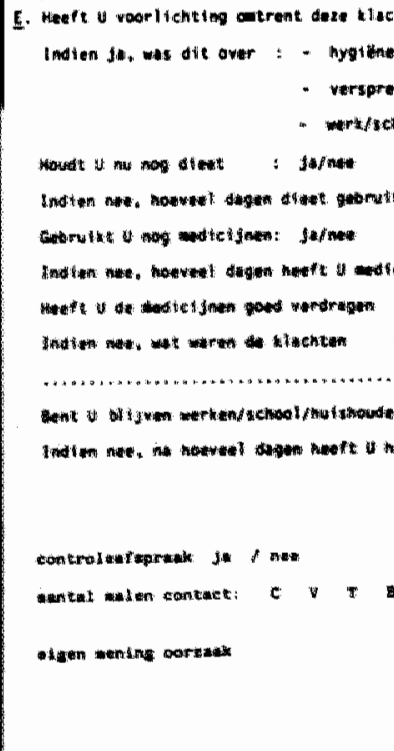 & 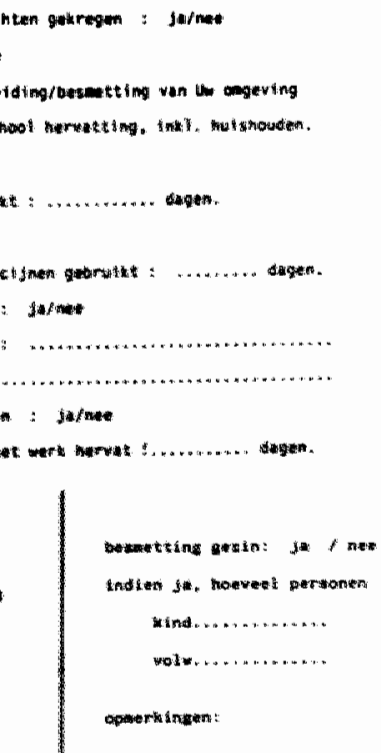 \\
\hline
\end{tabular}


INSTRUKTIEFORMULIER voor huisarts, artw-assi stent(e), doktersassistente.

1. Elke patient, ongeacht zijn of haar leeftijd. Kan wan dit onderzoek metodon.

2. Ga ne of de klacht voldoet as de onderzoeksudefinitie.

Onderzoeksderinitie: - en ontlasting van vloeibere or semi veste conilutentie: in - een defaeciatie rrequentie van ariemal of weer in de las ts te twalf uur:

3. Ga verder te werlk zoalis je dat gewend bent.

4. Vraag aan het elinde van thet gesprek (consult) aan de patient of deze zljn of havar medewerking wil verlenen aan een onderzoek over acute diarree.

5. Geef een korte uitleg over de aard wan het onderzoek, door bv. gebruik te maken van de volgende zinnen:

- het gaat eron het verloop van de klacht te weten te komen

- het gaat erom de oarzaken van uw klacht te weten te komin. etc..

6. Vul nu het enquleteformuller in thulsiarts of arta-ass.: het witte: doktersassistente het gele) en doe dit in de bruine ADIP enveloppe.

7. Overhandif deze bruine enveloppe aan de patient en verweldt dat de Ingesloten gebruiksaanijzine zorguldig moet worden opgevolgd.

B. Vertel de patient dat hij of alj ha ongoveer en week door een onderzoeker van de Fijksunivergit teft Limburg zal worten opgebeld, of aun hulis zal worden bezacht met betrekking tot een kleine enquete over het verdere beloop ven de klacht. (Indien mogelijlk gagrne het telefoonnumer van die patient vermelden op het enque teromulier bij aljn peranalia).

9. Bij en positieve kweekuits lag dient or dagen na de erate kwow oun tweede te worden ultgevoerd. Indien dit het geval is, zou jo bij hot mededelon van de ultslag aen de patient htm/haar willen vragen nog eons een wonster in te sturen (bruine envelopper te kemen halen). Op het enquateromulior hoor jo dan allean de kolom personalia in te wuilen en het felt, dat dit ean controle-(2e) kweek betrert.

\section{Opnerkingen:}

- Patienten woonachtig binnen de atad Mastericht brengen hat monster zelr naar hat Diagnostisch Centrum. Patienten woonachtig butten do at geven het monetier af an de huliartepraktijk; de prikdienet van het 2 liekenhulis $5 t$. Annadal zal verdier voor het vervoer naer het Diagnoatiach Centrum zorgen.

- Het monster kan 24 uur worden bewaard mits ondar in die 1 jakait. 


\section{Mremene Informatie an de doglnemera vam Groed $A$}

Start projekt ; 5 september 1983. Looptijd : Gen jaar.

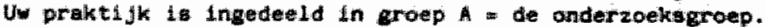

Dit betekent, dat zowel de hwisarta (arts-agbistent(e)) als de doktersassistente (n) om hiun nedewerking bordt gevragad.

Het is de bedoeling on vain ledere patient met de klocht acute diarree, die voldoet an de onderzoeksdefinitie (zie instruktieformulier), ongeache de leeftijd, ean faecesmonter te laten onderzoeken op het Bacteriologisch Laboratorium van thet 2 fielkerhul st. Annadal.

Woorop tast, dat zowel de huisirts (arts-assistent) als de doktersassiatente in het kontakt met de patient te werk blijven gavin zols ze dat gewend zifin. Indien de patiemt zich berejd heert verklaard mes te werken, wordt hem of haar in plates van de plastic container en het Dlagnostisch centrum-aanwraagformulier nu en brulne enveloppe mergegeveri, inhoudende: en monsterpotje: een lepeltje;

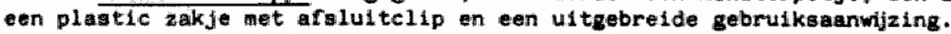

Voor de duur van alleten 14 onderzoek wordt gén gebrulk gemaakt van het Dlagnostisch Cientrun-aanvraagformulier, maar van en engueterormulier.

In die praktj.jken, warim de dokt rwasistente bij deze klacht, al of ntet in overleg met de hulsarts, gewend ls in eerate instantie deze patienter van advies te dienen, is het de bedoeling dat alleen door hav het gele enquteteromuLier wordt lingevuld en lat de brulne enveloppe aan de patient wordt meegegeven. Indien de hulearts (arts-assistent) de patient behandell, wordt het wite enquateformulier door hem of haar Ingevuld en in de brine enveloppe bijgesloten.

Op het enqueteformulier is geem ruimte om an te geven op welke micromorganismen gekweekt moet worden. Dit is ook niet nodig ondat van alle monsters een standaard bepaling bacterlologio en virologle automatich zal worden verrich.

Deze standaard omivat:

Van alle patienten: Salm/Shig ; Camplobacter : Veralnia; Rotavirus en een kweek op andere virustypen.

van kinderen tot 10 jaar ook nog: wormeiteren; cysten.

Indien $u$ bulten deze standaard eem extra of andere bepaling in dit monster verlangt dan 1 a het noodzakol1jk deze anvraag apart to vermelden op oen Diagnostigeh Centrum-ianvraagrormuli iter.

Uw praktijk wordt ower de titaleg op de gebruikel1jke wijte door het Diagnostigct Centrum geinformerd, met dien verstande dat de uttellag virologid weleens veerLem degen of langer op zich kan lation wachten.

Tenslotte aj nos vermeld, dat er voor de patienten geen kotten zijin verbonden arin dete faceskweok.

Mocht de uitalag van de kwe wragen oproepen, dan 1 a dearower vanzel reprekend kontakt mogelifk met het Bacteriologlsch Laboratorius 21 ekenhui s st. Annadal. Voor alle andere alken, dit projekt botreffende, kunt wich werden tot de projekted dera :

Pror, Dr. C. vam Boven, Capact teitsroep Wedische Heroblologle

Blomedisch Contruan fil.

Pois thus 616

$6200 \mathrm{MID}$ Mrastiricht. te1. 043-888572

. Wan Zutphen,

A.G. R1 Jnt.jes,

Capacl te 1 tsgroep Hul arartegeneegimude

Aamdind $\mathrm{ck}$ R, 1 .

Pos thuir 616

6200 Mij mastricht. ted. 043 - 616100 tat. 278/279/281 
a.

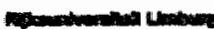

BIJLAGE VI

PROJEKT NOIP

\section{Algoment Informatie an de deelnewerg yan Groep}

Start projeikt: 5 neptember 1983. Loopt1jd : Atn Jaar.

U. praktijk is ingedeeld in groep B - de controlegroep.

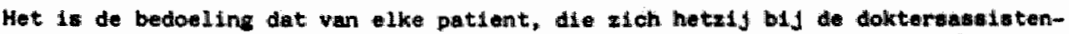
te. hetzi j bij de huisarts (artsimasistent) anmeldt ondat hij of zid vindt, dat hij of zij laot heeft van acute dilarree, op cen vookl ljat do nasam on het adres van de patlent wordt genoteend. Tevene wordt op deze lijat vastgelegd op welke wize het kontakt tat atand kwam (zle bijlage).

Bet weI of niet overeenstemen van do deflnitle van acute dierree zoals dere doo de pattent wordt gepresenteerd wet do voor dit onderzoek vastgestelde_defindtle

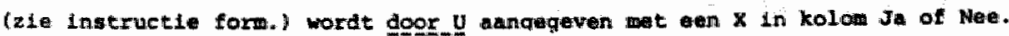

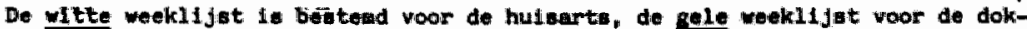
terasessistente.

Belden houden dus wen weklijst bij: eventuele doublures worden doer do projektgroep blj de verwerking gecorrigeerd. Daarom is het noteren wan het adres van ide patient absolut noodzakel1 jk.

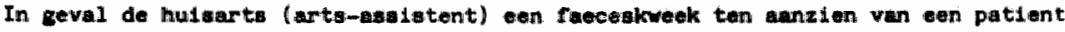
mat de klacht acute diarre gelndiceend acht, wordt $u$ verwocht in plaats van het Diagnostisch Centrum-anvrageformulier en de plastic container gebrulk to makon van de eet in de bruine ADIP enveloppe en daarbij hot witte enquateformulier In te rullen. op dit enqueteformulitar is geen rulmte on an te geven op welke micro-organismen $u$ het moneter wit Laten ondertoeken.

han het anqubtoformilier zit een bijlage vatgeniet, warop $u$ de verlangde bepaling kunt aankrulsen.

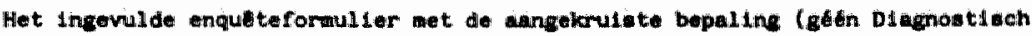

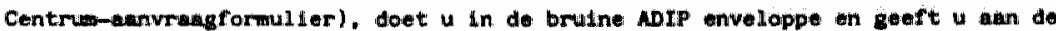
patient mee.

Het vervoer van het monater naar het Dlagnoatiach Centrua vindt plaats op de wijze zoels det in uw praktijk de gewoonte lis.

De uitilag van de kweek wordt u op de gebrulkell jlke Hijze toogozondien.

Mocht de ultalag yan do kweek vragen oproepen, dan le overlog wot het Bact. Lab.

St. Annadal vanzelf sprekend mogelijk.

Voor alle andiere zuken betreffende dit projekt kunt $u$ zlch wenden tot de projektleiders:

Prof. Dr. C. van Boven, Capaci teitagroe Medieche Microbiologit

Bionedisich Centrum R..L.

Postbus 616,6200 wid Mastricht. tel. 043-808572

w. van zutphen, A.G. Axjntjos

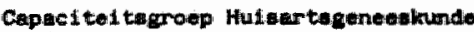
Randiel Jek R. L.

Postbus 616, 6200 Nanstat cht, to1, 043-016100

tet. $278 / 270 / 281$ 


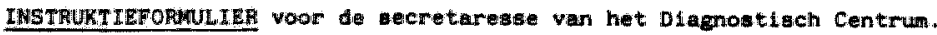

Start projekt : 5 deptember 1983.

Looptijid: 13 manden

1. Wrag degene, di de bruine ADTP-enveloppe argeert even te wachten ow aamen de: inhoud te kumen controlleren (geldt nilet voor de prikdienst).

2. Ga na of de pergonalia op het whte or gele engueteformulier volledig zijn ingevild en vil deze zonodig al mog man.

3. Ga na of de gegevens op het etjket van het raecesmongter volledig zijn en vul deze zchodig anog an.

4. Vul op het itte of gele enqueteformuler in de dubbelomijnde kolom, rechto boven. de datum en het tijdstip ven afnane in. Deze gegevens kunt u aflezen wan het etiket op het fuecesmongter.

5. Wul het Bacteriologle Lab.-formuljer in zoals dat gebruikelijk is. De gegevens komen nu echter van het wtte of gele enqueteformulier.

LET OF: neem de letter A of $B$ van het enqueteformulier (rechts boven) ook over op het lact.lab.-formulier, maar achrijf met viltstlrt. beze letter mag alleen leesbar aijn op het bovemste blad van het Bact. Lab anvraigromilier (mag dus nut doomdrukken).

Mls standard wilt u in:

- van lile patientem: Sila./Shig. Campylobact.; Yerainia; Rota-virus.

- vaor kinderen tot 10 Jaar ook nog: vomeleren en Cysten.

6. Cefef de bruine enveloppe (met het facesnonster en het witte of gele enquilem fomulier) en het Bact, Lab.-formulier garme zo viug mogelifk af an de ansiste van het Bact. Liab., die speciael net tit onderzoek is belast.

7. In de bruine enveloppe bevindt zich geem Diagnastisch Centrum-aanvraagformulie Voor de duur van dit onderzok wordt hilervan geem gebrulk gemakt in die a in, dat van $u$ wordt gevragad ten behove vam uw eigen administratie alleen die personall van het witte of gelle enquisteformulier op een Dhagnostisch Cantrunaanvragformulier over te nemen.

De berichtgeving van de uttglgg war de kweek naar de huisarts vindt op de ge-

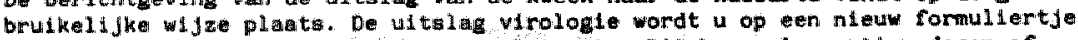
toegezander voor berdehtgeving an de huldarta. Dlt kam wel veertien dagen of langer op ich laten wehtien.

Het hartel1.jke dank woor uw meldewerklng. 
INSTRUKTIEFORMULIER anallst(e) Bacteriologisch Lab.

Start projekt : 5 septenber $1983 . \quad$ Looptijd: 13 maanden

In de bruine MDIP enveloppe bevindt zich een faccesmonster (rode top) in wen plastic zakje: en wit of en geel enquateformulier en tevens een bacterlologitaanvasgrormulifer, rechts boven voorzien van de letter a of $b$.

1. Vul in de dubbielomilinde kolom rechts boven op dit enquetromilier in: het kweeknummer (lab. number). de datum en het tidisto van inzetten van de kweekin:

2. Breng dit Wweeknumer ook an op het monsterpotje on MARKEER elk VIJFDE potje met een raod plakkertje onder het potje.

3. Voer de voor dit onderzoek afgesproken stamdaardbepaling Eacteriologie uit.

4. De rest wan het monster wordt koel weggezet t.b.v. het virologigch onderzoek door Dr. C. Bruggertan en Dr. J. Geleme. Het monster wordt door hen op gezette tijden apgehaald.

5. Maak em overzichtsilijst (klapper) van de per week binnengekomen monsters op valgorde 1. 2, 3, 4 etc. op naam van de patlent en kweeknummer. Tevens wordt achter de navin de uitsiag wermeld en bij positief resultat de naam van de verwekker, Indien dat reeds wogelijk is. Laat en kolom open voor de uftalag virologit.

6. De enquateformulieren worden doorgegeven an do administratie van het Bact. Lab. voor verdere verwerking (ultslag, berichtgeving mulaarsen).

7. Regelmatig zullen medewerkers van de Capaciteltigroep Hulsartageneeskunde langskomen om de gegeveng in to zien en/or alvast te noterer. Dit is nodig woor het ultvoeren van en follow-up onderzook onder teze patienten.

8. Bij wisseling van plaats op het laboratorlw wordt de opvolger(ster) naumkeurig geinformeerd. (ingewerkt).

Met martijke dank woor de redewerking. 
BIVLAGE IX

я.

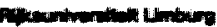

PROJEKT ADIP

INSTRUKTIEFOHMULIER voor de administratie van het Bacterlologisch Lab.

Start projekt : 5 september $1983 . \quad$ Loopt1jo: 13 mmanden

1. Leg van de wte of gele enqueteformulieren een archiof aan (ordmer).

2. Maak van de voor- on achterkant van het witte of gele enqueteformulier eem fotokople: : Deze kopleän blijven op de administratie in de ordner.

3. De originele enquateformulieren met de uitolag worden regelmatig door medewerkers wan de capacitheitsgroep Huisartsgeneeskunde opgehaald...

4. Voor de verwerking van de uttslag wordt de normale gang van zaken bewandeld.

5. Ieder BacterLologiach Lab.-aanvraagformulier ia voorzien van een letter A of een letter B rechts boven..
$A$ anderzoieksgroep.
B controlegroep.

Dit gegeven is van belang vaor um adminisitratie.

Voorkomen mort worden dat patilenten TEN ONRECHTE en rekening ontvangen. 
Bristan $\mathrm{X}$

я.

IHSTHUKT: Virolonie.

\section{PROJUAT ADIP}

1. Regelmatig ophalen van de raecesmonsters op het Bacteriologlech taboratoritu.

2. Het uItvoeren van de tandeand (afgesproken) virologische topulingen.

3. Het verzorgen van de uts lag fop het voongedrukte formuler in die zin: dat op de administrath van het Bacterlologisch wab. de uitag wan worden vermeld og het enqutetormulier bi dat de ultalag op het Diagnostisch Centrum ganwelg wo ver verdere verzending near de hulsarts.

4. Het anleggen van een Mapper wet de of telagen op neam an area van to patient.

5. Het opslan van de faecesmonstors in wen vrtesikit. 


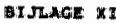

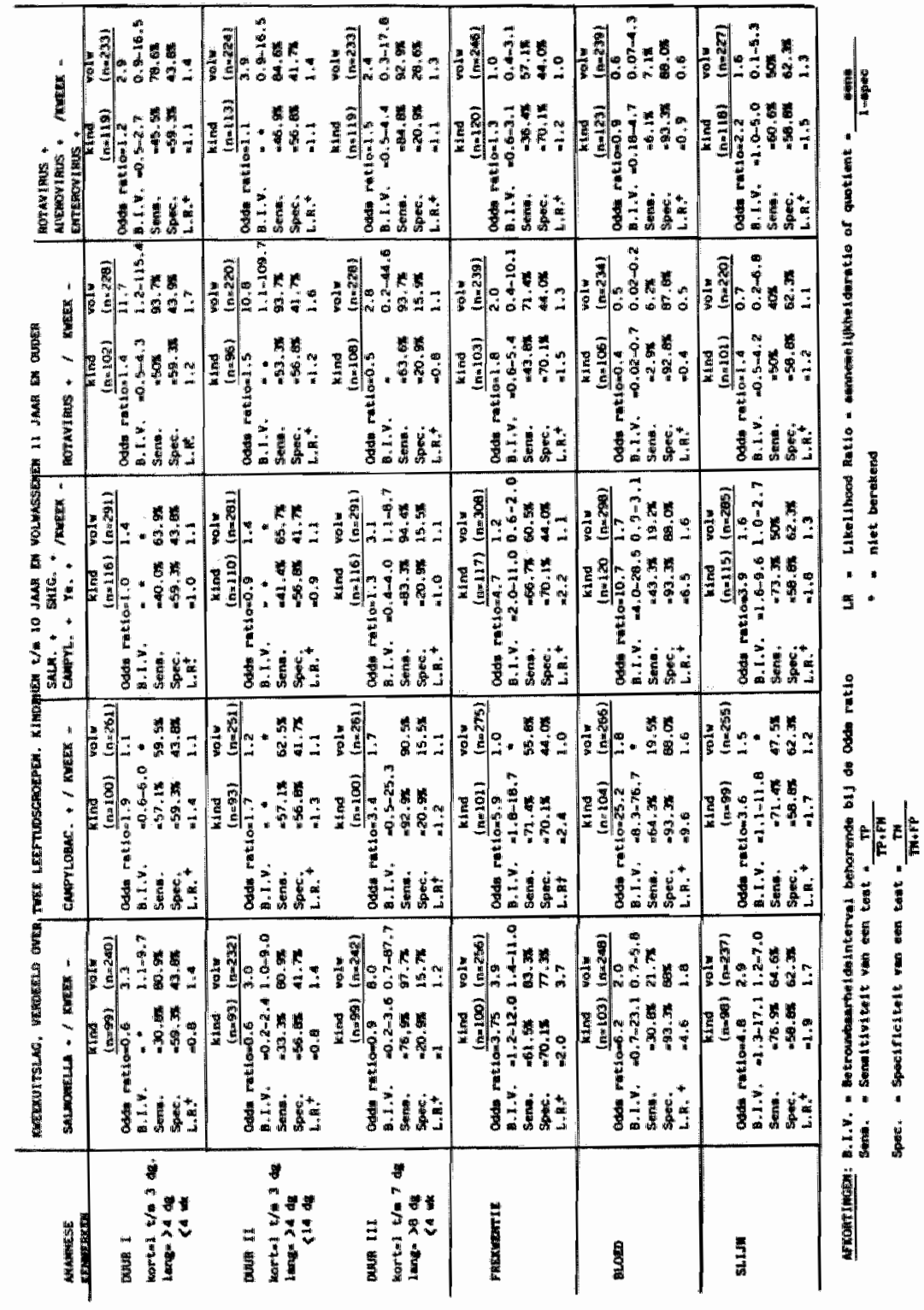


Brsmates xat

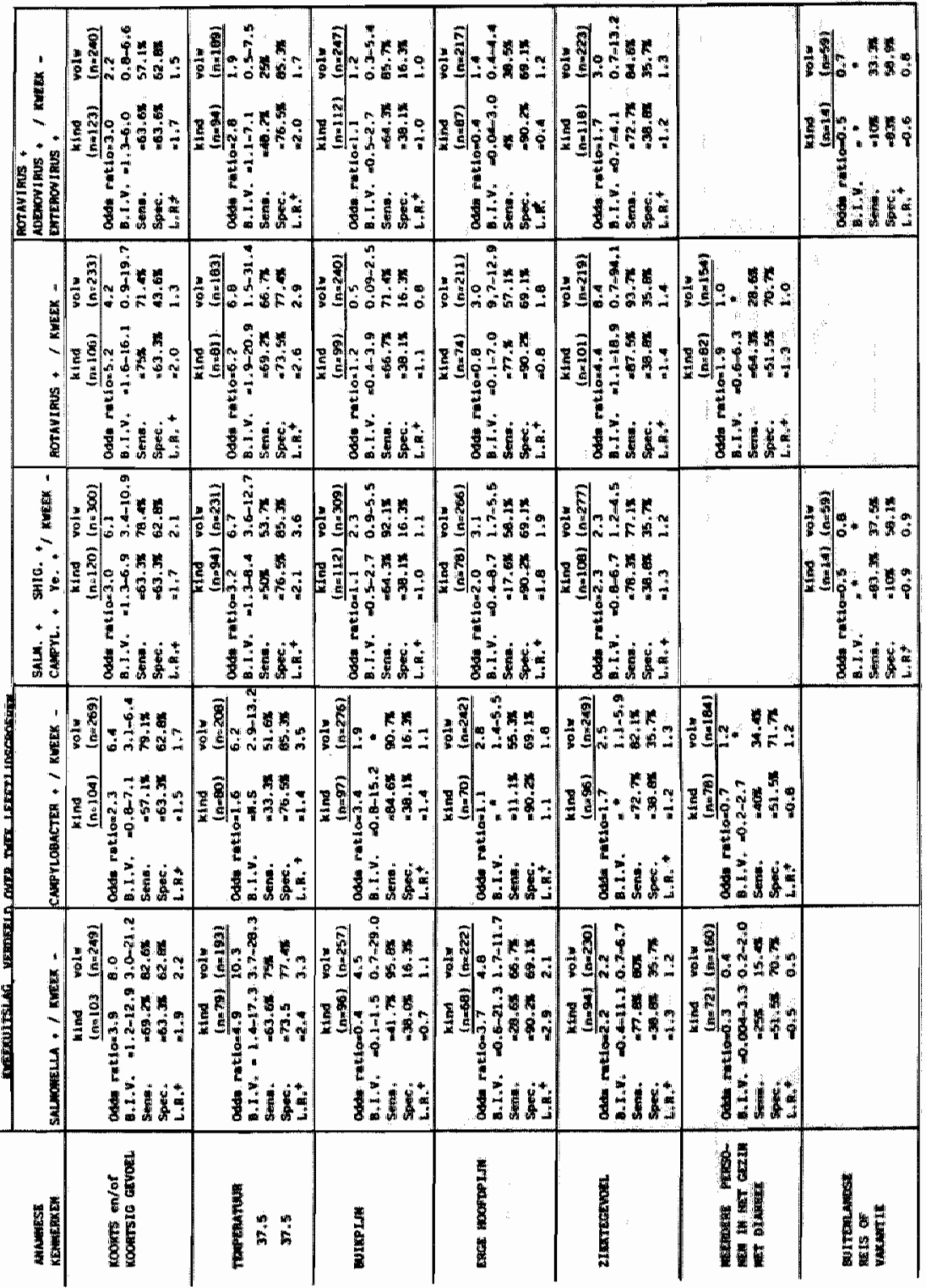


STILAE XIt

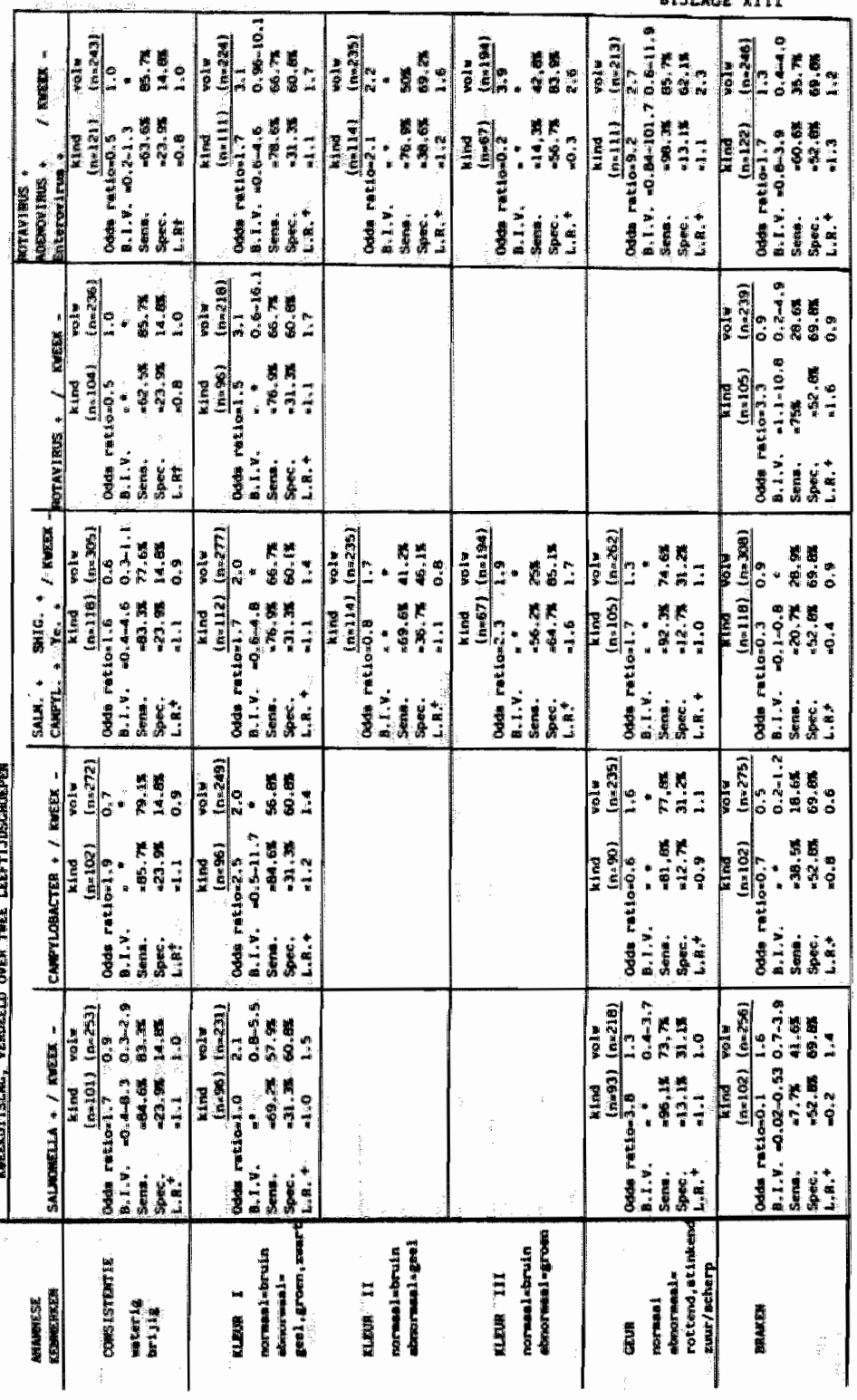




\section{DANKWOORD}

Aan de totstandkoming van dit proefschrift hebben vele huisartsen en doktersassistentes belangeloos een bijdrage geleverd. Hen dank ik op de eerste plaats.

Vele medewerkers van zowel het Bacteriologisch en Virologisch Laboratorium van het Academisch Ziekenhuis Maastricht als van de capaciteitsgroep Medische Microbiologie van de Rijksuniversiteit Limburg ben ik voor hun inzet gedurende de onderzoeksperiode dank verschuldigd. In dit verband wil ik nadrukkelijk mevr.dr. M.S.M. Daniëls-Bosman, mevr.dr.C.A.M.V.A. Bruggeman en de heer dr.J. Galema vermelden.

De medewerkers van het Diagnostisch Centrum ben ik erkentelijk voor hun loyale opstelling en improvisatietalent, vooral wanneer de instruktievoorschriften bij het monster toch niet werden opgevolgd op de wijze zoals bedoeld.

In het bijzonder wil ik Prof.dr.C.P.A. van Boven en Prof.dr.w. Brouwer danken voor hun kritische opstelling en continue steun.

Prof.dr.F. Sturmans en Prof.dr.H.G.M. van der Velden dank ik voor hun deskundig kommentaar, dat zij bovendien op korte termijn hebben willen leveren.

Dr.W. van Zutphen heeft niet alleen aan de wieg van dit proefschrift gestaan, maar is tevens een belangrijke steunpilaar geweest bij het tot stand komen. In dit verband mag ook de hulp van mevr.P. Stouthart niet onvermeld blijven.

Met DrS.I.L.P. van Leeuwen deel ik de liefde voor de Nederlandse taal. Zijn kommentaar heeft deze liefde nog verder doen toenemen. Mevr.dr.E.E. Stobberingh ben ik erkentelijk voor haar steun, met name de heldere wijze van formuleren.

Voor de Engelse vertaling van de samenvatting dank ik Dr.B.I. Davies.

Zeer bijzonder ben ik dank verschuldigd aan mevr.M. Bruijstens, die vanaf de start van het onderzoek een niet aflatende steun is geweest en het manuscript zijn uiteindelijke vorm gaf. 
De auteur werd op 23 augustus 1943 te Utrecht geboren.

Na zijn middelbare schoolopleiding an de bijzondere HBS-B F.de Munnik te Utrecht studeerde hij van 1962-1970 geneeskunde aan de Rijksuniversiteit te Utrecht.

$\mathrm{Na}$ de vervulling van de militaire dienstplicht als reserve officier-arts vestigde hij zich in 1972 als huisarts in de gemeente Maarn in associatie met $L$. Bussemaker.

Hij was mede-oprichter van het gezondheidscentrum Maarn/Maarsbergen en nauw betrokken bij de beroepsopleiding van het Utrechts universitair huisartseninstituut, zowel inhoudelijk als organisatorisch.

Van 1980-1985 was hij als wetenschappelijk hoofd-medewerker verbonden aan de capaciteitsgroep Huisartsgeneeskunde (voorzitter: prof.dr.W. Brouwer) van de Rijksuniversiteit Limburg.

Hij was vooral betrokken bij de stage Praktisch Medisch Onderwijs in de Huisartspraktijk voor $5 e$ jaars studenten. Daarnaast werden in de medische fakulteit funkties bekleed als vice-voorzitter van de gezondheidszorgcommissie, lid van de fakulteitsraad, lid van het fakulteitsbestuur als portefeuillehouder gezondheidszorg en vicedekaan.

Vanaf 1986 is hij direkteur patientenzorg in het $s t$. Jans Gasthuis te Weert. 